$\pi$

$$
{ }^{2}
$$

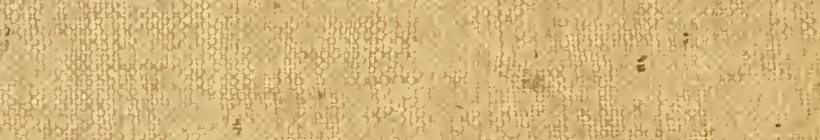

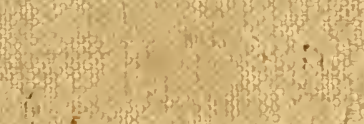

to
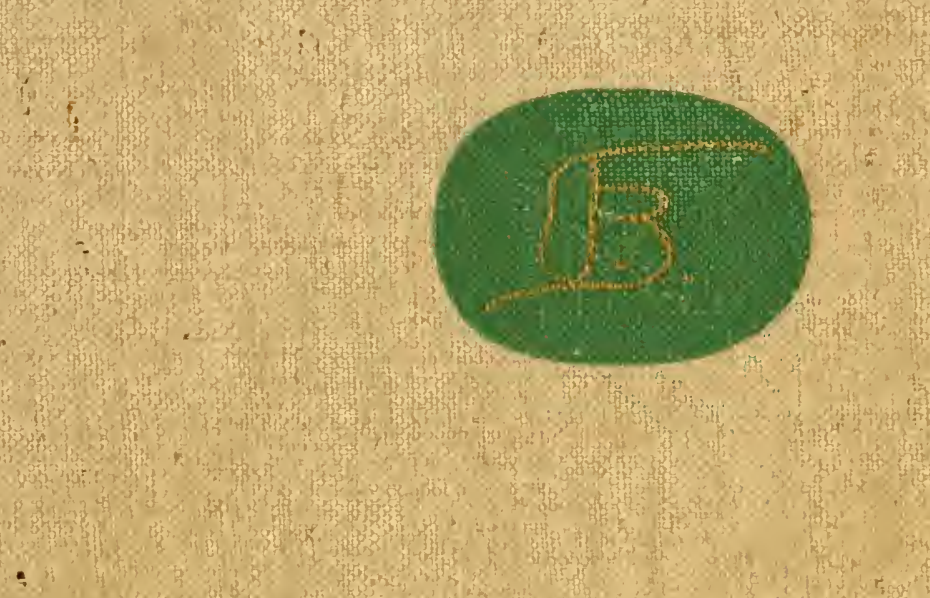



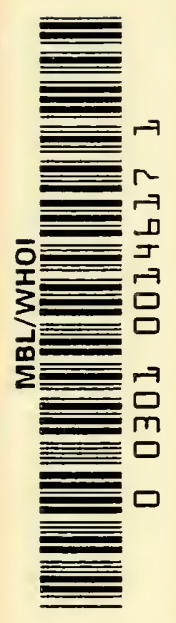





\section{NATURALIST AT LARGE}






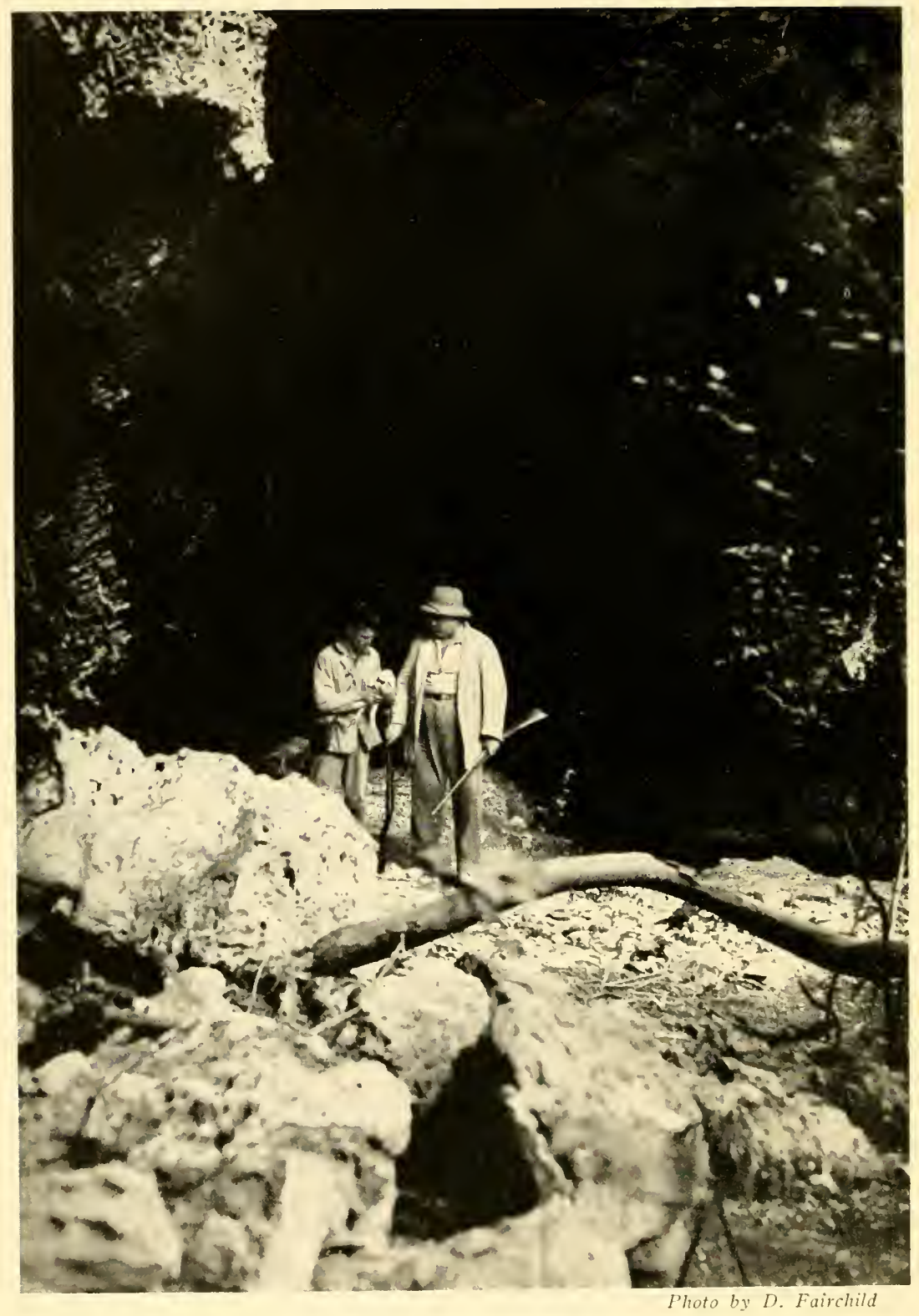

The author and J. C. Greenway, Jr., with a Bahama Barn Owl, at the mouth of a cave near Landrail Point,

Crooked Island, Bahamas 
Naturalist at Large

\section{THOMAS BARBOUR}

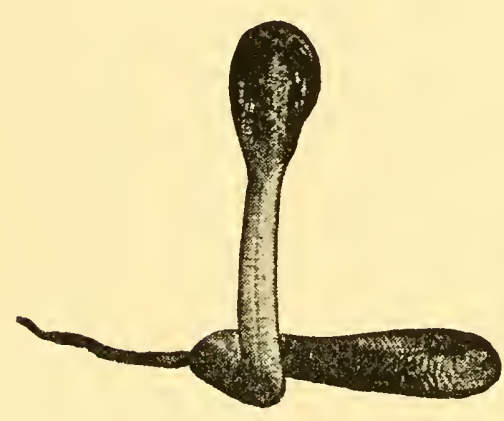

I L L U S T R A T E D

An Atlantic Monthly Press Book

Little, Brown and Company - Boston

I 944 
COPYRIGHT I 942 , I 943 , BY PHILLIPS KETCHUM, TRUSTEE UNDER AN INDENTURE OF TRUST MADE BY THOMAS BARBOUR FOR THE BENEFIT OF MARY B. KIDDER, JULIA A. BARBOUR AND LOUISA B. BARBOUR, DATED JULY I 9, I 943

ALL RIGHTS RESERVED, INCLUDING THE RIGHT TO REPRODUCE THIS BOOK OR PORTIONS

TISEREOF IN ANY FORM

Published September 1943

Reprinted September 1943

Reprinted October 1943

Reprinted November 1943

Reprinted January 1944

ATLANTIC-LITTLE, BROWN BOOKS ARE PUBLISHED BY LITTLE, BROWN AND COMPANY IN ASSOCIATION WITH THE ATLANTIC MONTHLY PRESS 


\section{Dedicated to ROSAMOND P. BARBOUR With great affection and respect}

$A$ warm salute to Edward Weeks and Dudley H. Cloud for guiding the clumsy feet of a tyro 

Peregrination charms our senses with such unspeakable and sweet variety that some count him unhappy that never travelled - a kind of prisoner - and pity his case; that from his cradle to his old age, he beholds the same still, still the same.

- Robert Burton 



\section{Contents}

PART I THE MAKING OF A NATURALIST

I. Confessions of a Naturalist

2. The Family

3. The Mind's Eye

4. "For Richer for Poorer"

5. Wallace and the Dutch East

6. Flying Fish and Turtles

7. The Sea and the Cave

8. Cuba

9. The Bahamas, Old and New

ı. Reptiles in the West Indies

PART II THE SEDENTARY NATURALIST

II. Naturalists in Dispute

12. Three Friends

I 3. Mr. Justice Holmes

14. Lifework

15. The Glory Hole

16. Those Who Help

17. Panama

18. Scientists and Philosophers 
PART III THE LEISURELY NATURALIST

19. Florida and Some Snakes

22 I

20. The Tests of Evolution

237

2I. Whales

245

22. Latin America

250

23. Africa

264

24. In Retrospect

279

APPENDICES

I For Zoographers Only

299

II Render unto Caesar 


\section{Illustrations}

The author and J. C. Greenway, Jr., with a Bahama Barn Owl, at the mouth of a cave near Landrail Point, Crooked Island, Bahamas Frontispiece Sarah Elizabeth Barbour, about 1890

Rosamond and Thomas Barbour, by John Singer Sargent, I919

The big cobra killed near Lucknow on the fifteenth of November, igo6

The women's canoe with no outrigger, only used on short journeys; The men's canoe, used for trips to sea. Humboldt Bay, 1907

The Great Karriwarri at Tubadi Village, Humboldt Bay, New Guinea

Two Karriwarris at the village of Tubadi in Humboldt Bay; Communal long houses over the water at Ansus, Japen Island, in Geelvink Bay, Dutch New Guinea

R. P. B. at Monokwari; Natives of Humboldt Bay

Utowana in Port Castries Harbor, St. Lucia; Three deep-sea fish drawn by Alexander Agassiz

Dancing Girl Orchids recall the market at San Salvador

The tropical forest primeval along the upper Jesusito River, eastern Panama 
The Harvard Garden, Soledad, near Cienfuegos, Cuba 88

The author and "Lizzie" at Soledad, I941; On the steps at the Aula Magna, University of Havana, March 1930

100

David Fairchild and William Morton Wheeler at Barro Colorado Island, 1924; Henry B. Bigelow aboard the Grampus, 1913; John C. Phillips, 1934144 Three of George Nelson's finest fossil reptiles: A sailback lizard, Edaphosaurus; Unique mount of Ophiacodon; Unique type of Dynodontosaurus oliveroi Romer from southern Brazil

The Hunter home from the kill. Churima rests after bringing in a peccary to camp; The author and Juicio, the chief of all the Chokoi Indians with whom we came in contact

The author with three Indians near Garachiné, westearn Panama, I922; The Laboratory at Barro Colorado Island

One of the giant Bombacopsis on Barro Colorado Island; Shore-line vegetation at Barro Colorado Island

Our tent by an almost dry stream in eastern Panama; Churima's house, where we hung our mosquito bars on various occasions

Alexander Agassiz and the Sultan of the Maldive Islands aboard the Amra, I90 I

A yearling Greater Kudu in the Kruger Park

Bird Island, forty miles off southeast Africa

T. B.'s office in the Agassiz Museum 


$$
\text { PART I }
$$

THE MAKING OF A NATURALIST 



\section{CHAPTER I}

\section{Confessions of a Naturalist}

To

USE a witty simile of William Morton Wheeler's in a sense in which he did not use it, I may say that in the home I am a poor Peruna-soaked Methodist, but in the Museum I am a High Church port-wine-drinking Episcopalian. I came to Boston a little too late in life really to enjoy the iteration and reiteration of Back Bay society gossip. I am inclined to creep off by myself when Vincent Club politics hold the floor. To be sure, I supply a president and vice-president to the Club. These are daughters whom I see occasionally at eventide. I am old-fashioned and eat my breakfast early; also, I have insomnia and go to bed early. My more socially-minded housemates arise for a cup of black coffee and a cigarette, timed so as not to spoil the appetite for luncheon. (I'll confess this was written before the war changed many habits.)

I recall once taking a distinguished Southern Bishop of my Church to a meeting of the Saturday Club. As we walked away, he said, "The talk at that table has canceled out an awful lot of banality." I have also enjoyed the Wednesday Evening Club and the Wintersnight. Being the only male in a household composed of singularly masterful women, I have, for the sake of peace, apologized and confessed to about everything from mayhem to mendacity - perhaps most often to intemperance. My transe gressions along the latter line, however, have been pitifully 
moderate and puny compared to what I often observe and hear about in others.

Now in the Museum all is different. My staff does not laugh at my jack-of-all-trades inclinations. They might, for I have collected and described mammals, birds, reptiles, amphibians, fishes, and have collected countless insects and marine invertebrates which others have described. I have been by inclination an old-fashioned naturalist, many tell me perhaps the last of the breed. My colleagues prefer to know more and more about less and less and so are infinitely more erudite than I.

No man has ever had more fun with his chosen tasks. When I am taxed with, "You never do anything that you don't want to do," my answer is, "Not if I can help it." Father, bless him, left me well endowed with this world's goods and with a nervous, high-strung desire to hurry about whatever I am attempting to do. This has been my chief source of strength - and perhaps of weakness, too. I have loved the three Museums in Boston, Cambridge, and Salem, which, from time to time, I have been permitted to correct as if they were human friends.

I do not think I am guilty of conceit, as was Rafinesque. He wrote at the close of his autobiography:-

Versatility of talents and of professions, is not uncommon in America; but those which I have exhibited in these few pages, may appear to exceed belief: and yet it is a positive fact that in knowledge I have been a Botanist, Naturalist, Geologist, Geographer, Historian, Poet, Philosopher, Philologist, Economist, Philanthropist. ... By profession a Traveller, Mer- 
chant, Manufacturer, Collector, Improver, Professor, Teacher, Surveyor, Draftsman, Architect, Engineer, Pulmist, Author, Editor, Bookseller, Librarian, Secretary . . . and I hardly know myself what I may not become as yet: since whenever I apply myself to anything, which I like, I never fail to succeed if depending on me alone, unless impeded and prevented by lack of means, or the hostility of the foes of mankind.

God gave one ever-useful attribute - realistic appreciation of my own limitations. This has saved me from taking positions which I knew I could not fill acceptably and generally from biting off more than I could chew. 


\section{CHAPTER II \\ The Family}

A strong family likeness runs through our family. My brother Robert looks extraordinarily like our GreatUncle Robert, for whom he was named. I went into the State House in Richmond one day with my friend, Cotesworth Pinckney, to see whether there might not be portraits of James Barbour and Phillip Pendleton Barbour there, since both had been Governors of Virginia long ago. We had barely entered the room when Cotesworth said, "Well, there's one of them all right," and pointed to a picture which turned out to be labeled "James Barbour." And yet these were distant kin.

My three brothers and I present four types. My brother Robert, who is two years younger than I am, is the mathematician of the family. His facility with figures is amazing to me, for I am hopelessly incompetent in this respect. $\mathrm{He}$ also has marked mechanical ability, coupled with manual dexterity, and even before he went to the School of Mines at Columbia he had a workshop on top of Father's New York house - now the Museum of Modern Art, I I West 53 rd Street. This workshop was fitted up with lathes and all sorts of mechanical tools. There with David Dows he built an automobile, one of the first in the city, which actually ran when it was lowered into the street. One of the more amusing aspects of that feat was the confidence David showed in their combined ability. He bought 


\section{The Family}

the horn before they began work on their contraption. Robert has now retired to well-earned leisure, after a useful career in charge of the manufacturing department of the Linen Thread Company.

My brother Warren, four years younger than I am, started out as a chubby, rolypoly little boy. Just as he was about to enter Princeton, the death of one of my father's business associates made an opening which Father thought was too good to pass up, so Warren went into the office. Early in life he developed tuberculosis and spent some time in the Adirondacks where Father had a big hunting preserve, in the care of Grandmother's friend, Dr. Edward Trudeau. He was entirely cured, went to Bermuda, and in less than no time became well known as an amateur boxer. He became amateur champion heavyweight of the United States in I9Io and could at this time probably have outboxed anyone in the country; but Mother did not take kindly to the idea of his fighting and naturally he gave it up. He is now United States Senator from New Jersey, having piled up a greater number of votes than any other Republican candidate in the last election, which means something in New Jersey, where election practices are still what they were in other parts of the country fifty years ago.

My brother Frederick, born in 1894 , has now inherited the presidency of the Linen Thread Company, but, to my mind, shows great good sense in taking time off for the field sports which he loves. This has given me an opportunity of late years to see rather more of him than of my other brothers, since we both love to hunt and to fish. Frederick is the finest hand with a wet fly for salmon that 
I have ever seen. He can throw a fly a prodigious distance with absolute accuracy and then at the end of the cast have the fly just touch the water as if it were a bit of falling thistledown.

My brothers and I owe Father several different debts of gratitude. He left us not only with the means but also the opportunity to take up our several totally different ways of living. I was enabled to build up a fine library and to spend my life as a volunteer servant of Harvard College. Father loved the out-of-doors and was a good observer himself in the field, but I do not think he was particularly pleased that I became a naturalist. He hoped that I would follow him in his business.

He delighted, however, in the fact that for many years he had my other brothers in association with him in either the executive, the selling, or the manufacturing ends of the Linen Thread Company and the American Net \& Twine Company. During the last years of his life he extended himself dangerously, acquiring a locomotive works in Chicago and other scattered interests which were difficult to supervise adequately. I owe a deep debt of gratitude to my brothers who at his death unwound the tangled skein of his affairs, something at which I was incapable of giving more than a small share of assistance. By injudicious handling of his enormous outstanding loans they might easily have landed me in the poorhouse, but they were well equipped to make their way in the world.

No two persons were ever more completely unlike than my mother and father. My mother loved New York, and by this I mean the city itself. None of her younger days 


\section{The Family}

had been spent in the country, for her father - my grandfather - had moved up from Charleston, South Carolina, to New York a short time before the Civil War, taking with him his slaves. He was left impoverished and died shortly after the war was over. He was a Southern sympathizer, and suffered deeply as a result of his convictions during the last few years of his life in New York. My grandmother Sprague moved with her young brood to Geneva, Switzerland, where one could live at small cost. After three years, when the financial outlook was a bit brighter, they sailed back to America and entered New York Harbor to see a column of smoke rising from the lower end of Manhattan Island. It was the storage warehouse containing all their earthly belongings - everything they owned was lost.

Mother was a tall and stately person to the very end of her life. She was tall for a woman, for she was slightly over six feet. I have no doubt that in her youth she was very handsome.

Mother had a deeply religious character, Calvinistic and fundamentalist, but utterly sincere in her belief. I never knew a person who tried harder to be just and fair. She leaned over backward in this respect. Brought up as she was, it was a little difficult to convince her that there was no essential difficulty in accepting such modern scientific beliefs as the theory of evolution without jeopardy to the faith which she treasured so sincerely.

She and my father's mother did not particularly care for each other and I think the reason really was that the male members of Grandmother's family on both sides, the Warrens and the Sayreses, were officers in the Union Army, 
whereas Mother's family were not at all convinced of the righteousness of the Northern cause. They were in fact Copperheads.

While Mother did not play any musical instrument, she had a lovely soprano voice and took music lessons to well within the years of my memory. She and Father had the same seats at the Opera for many years and I remember particularly the pleasure she derived during the last years of her life from the Bagby Concerts which she attended very regularly.

Mother was just, as I have said, but she had a sharp and flaring temper and she thrashed us youngsters on numberless occasions. I remember that she had a giant hairbrush which had belonged to Grandfather Barbour which was specially reserved for spanking. Warren terminated its usefulness permanently when he surreptitiously slipped a flat stone inside the seat of his pants and the hairbrush was shattered once and for all, to our great joy.

She went to the Adirondacks with Father from a sense of duty and while she liked to row a boat about the lake herself for exercise she never fished or hunted, nor do I believe that she could have told a beet from a carrot when they were growing in the garden. She had no knowledge of or interest in the country-no interest in nature, in birds or flowers, nor in woods or fields.

Father on the other hand inherited his mother's love of outdoor life, her love of shooting and fishing, and a very considerable knowledge concerning the birds and animals which he came across from time to time. He passed this enjoyment of shooting on to his sons. His father acquired 
a share in what was called the Tupper Lake Club in northern New York, and went there to shoot and fish with Grandmother when Father was a little boy. Gradually the members died off and Father acquired the property. This consisted of about 145 acres on the southeasterly shore of Big Tupper Lake. And Paradise Point, on which the famous Coleman's Spring was the outstanding feature of the property. Here Father built a camp where for years he came for relaxation and enjoyment after the hard life so characteristic of the businessmen of his day, who speculated daringly albeit successfully, but certainly to the peril of their nervous system. Father had his father's passion for acquiring land. Grandfather bought tracts of land scattered over New Jersey, usually because there was a pretty view over some attractive pond, whereas Father kept adding to his Adirondack holdings until at his death he had at least 45,00o acres.

Father was not skillful with his hands any more than I am, although his handwriting was superb. Nevertheless, he loved to watch work and the work he liked best was the building of stone walls. I often drove oxen hitched to a stone boat and hauled rocks with him. My brother Robert, the mechanic, ran the big stone crusher, and every year we built roads and stone walls. When it was time to knock off Father went for his evening bout of fishing with Dan Hinkson, who simply adored him. Father had a stately figure, and was possessed of great personal beauty and dignity. He was six feet three inches tall and often said, "I and my four boys are just a half inch shy of being thirty-one feet of Barbour." Unfortunately for me I was the tallest of the lot, and I have suffered from colliding 
with chandeliers and low doorways, and from short sleeping-car and steamer berths, all my life.

A flood of pleasant memories surround the stories of our life at Tupper Lake. I can close my eyes and see the great flock of lovely swan swimming past Warren Point just a mile or so north of Father's Paradise Point camp, where for several summers I had a lovely home of my own, thanks to his generosity. He took the greatest pride in his swan, his peacock, his Kerry cattle, his oxen, and his bees, and in the ever-changing beauty of the scene which unfolded as summer changed to autumn in the north woods.

My three brothers and I were a fortunate crew.

After Father's death it was quite obvious that the reserve at Tupper Lake was more than we four could swing. Father's estate, cut in quarters and the death duties paid, was of a quite different order of magnitude from what it had been when he was alive. Fortunately the State of New York needed lands for a forest reserve and to protect watersheds which, in the future, may have to be drawn upon for the use of the City of New York. They bought all of the unimproved acreage. The farm and its various buildings, Father's camp and my camp, were purchased by the American Legion as a tuberculosis sanatorium. I have often wondered whether the convalescent Legionnaires have appreciated the beauty spread before their eyes. Mount Morris, one of the handsomest domes in the whole Adirondacks area, lies right directly across the lake from these camps, and when the autumn foliage is richest the reflection in the lake is frequently one of breath-taking beauty. 


\section{CHAPTER III \\ The Mind's Eye}

I

WAS born August 19, 1884, on the island of Martha's Vineyard. My mother went there to visit her mother, and I arrived unexpectedly. When I was six weeks old my father and mother went to Ireland on business, and I went along in a bureau drawer of the old Cunard liner Umbria my peregrinations began early. Father went back and forth to Europe several times a year. He had succeeded his father as a director of William Barbour and Son, the firm founded by his great-grandfather, which had linen mills near Lisburn in Ireland.

When I was eight years old we made a long tour through Europe. I remember vividly the terror caused by the cholera outbreak in Hamburg that year. We were visiting at Mr. Fritz Krupp's house at Essen, an extraordinary establishment. The house was a palace, the gardens enormous. The place was entirely self-contained, Mr. Krupp even having his own fire department. I think his Arab horses impressed me more than anything else, although I remember staring with wonderment at a room stacked high with Oriental rugs. Mr. Krupp, who had been an old friend and schoolmate of my father in Germany, explained that the Sultan of Turkey was often short of cash and occasionally paid for his munitions in commodities. We had a wonderful time pestering our governess by doing everything mischievous we could think of; my brother Rob and I tipped 
the young Crown Prince of Bavaria into a rather deep fountain, and for this, naturally, we got the devil.

I recall that when we visited the Zoo at Frankfurt am Main, the keeper reached into a cage, opened a tiny box, parted the cotton wool - and there, curled up, was a pigmy lemur. He said it was the smallest of all the monkey family. I can see the little beast now in my mind's eye - a tiny, gray, fuzzy ball scarcely larger than a mouse. The event came back to my mind the other day when I put a lovely little mounted specimen of Microcebus on exhibition.

The cholera got so bad that we hurried back to America, and I cannot think of any events that played much part in my wishing to become a naturalist by profession until I 898, when I had typhoid fever. My brother Rob and I both had typhoid fever twice. In those days, no one knew the difference between typhoid and paratyphoid - which, I suspect, accounts for our unusual misfortune.

After the first of these illnesses I was shipped to Eau Gallie, Florida, where my grandmother had a winter home. Grandmother, born Sarah Elizabeth Warren, was an extraordinary character. She was the best shot with rifle or shotgun I ever knew, and she threw as pretty a salmon or trout fly as my brother Frederick. She was devoted to Thoreau, and went to Keene Valley to hear Dr. Thomas Davidson lecture on philosophy. I once met him at her house in Paterson, New Jersey. He said, "Where there are two Toms together, the older is a fool." I felt sheepish but, curiously enough, remembered the remark.

Grandmother was a born naturalist. She loved the outof-doors, and with her I made my first memorable excur- 


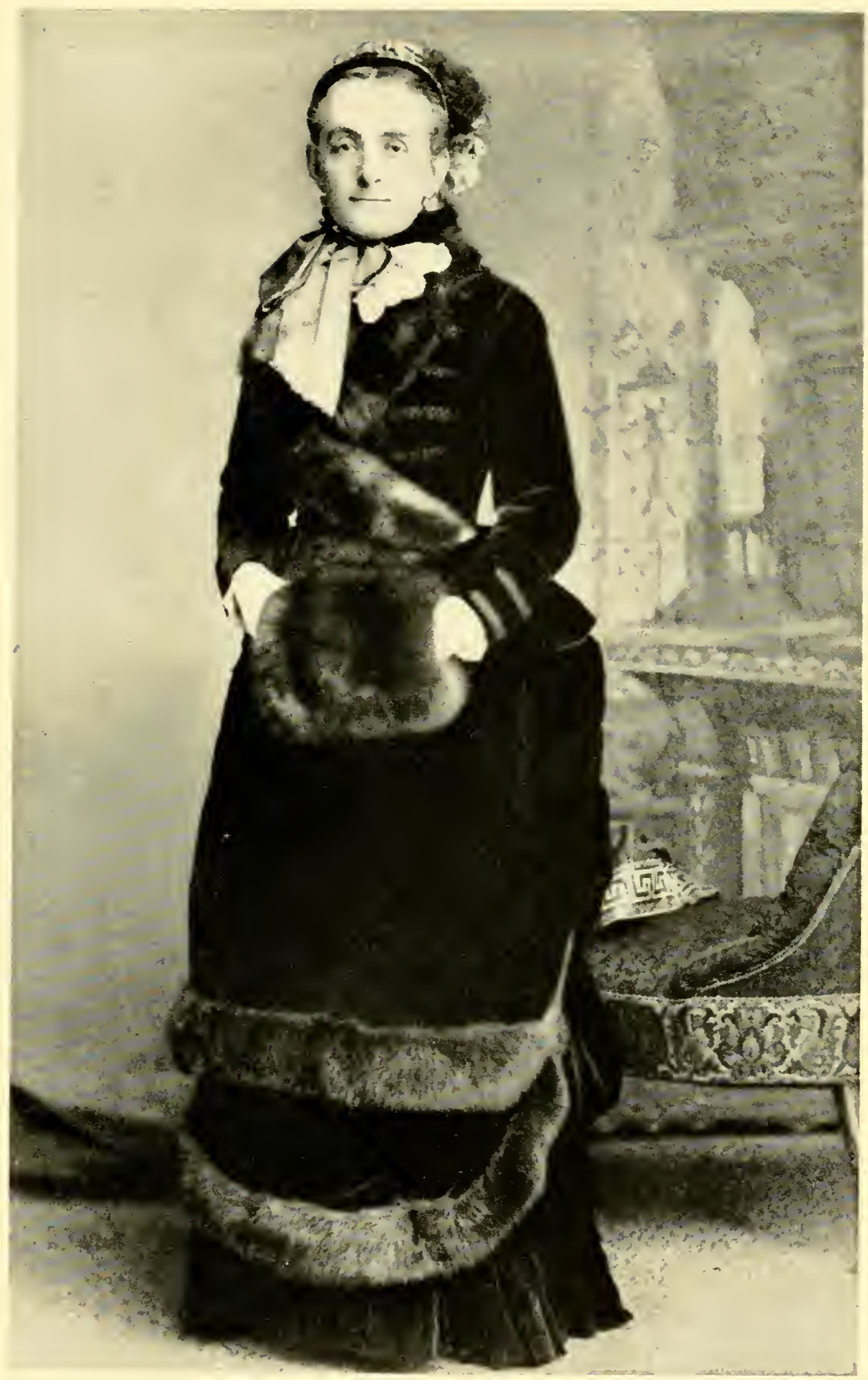

Photo by Pach Bros.

Sarah Elizabeth Barbour

$$
\text { About } 1890
$$



sions. We went to Lake Washington, at the head of the Saint Johns River in Florida. We put a boat on a wagon, Gene Kinniard drove the team, and I rode a marsh tacky alongside. We used to leave the house at two o'clock in the morning and get to the lake about daylight. We built fires and cooked our meals at the Cabbage Mound, a tall grove of cabbage palm trees, high and dry in the midst of a quaking bog, which extended for miles after a heavy rain. The fishing was good, and the birds were a sight to behold. I never go near this part of the world now without driving from Eau Gallie out to the Mound, a drive of about half an hour by motor; but every inch of the road, indeed of that whole country, is loaded with golden memories.

My grandmother was not particularly tall but she was strikingly beautiful, even in her old age, and entirely aware of the fact. She was inordinately proud of her hair, which reached almost to her heels when she let it down. She was usually as brown as a gypsy and was as restless as I am. It was nothing for her to slip quietly away and then send us a letter from Stavanger in Norway, where she had gone salmon fishing, or from Cuba, or from Gaspé.

Her father was a clergyman, the Reverend Dr. David Allen Warren, who started as a Presbyterian but got into a row with the Synod because he declared that the Lord's Prayer was incorrectly translated - it was insulting to ask the Lord not to lead us into temptation because, naturally, He would not be so unkind as to do any such thing. The congregation, being very fond of him, slid with him over into the Congregational fold with its complete autonomy, and he continued to preach in Verona, New York, until his death.

Verona was near an Indian reservation, and Grand- 
mother thrilled me with tales of how, as a little girl, she would come down early in the morning to dig out the pine knot which was buried in the embers each evening so that the fire could be easily kindled the next day. She would sometimes find three or four Indians sleeping on the floor in front of the hearth. They would leave a haunch of venison, or fish from Oneida Lake, or berries, out of gratitude for the hospitality. The time, of course, was well over a hundred years ago.

Grandmother and I went down to Miami from Eau Gallie. The railroad had only been built a short time before, and we stayed at the Royal Palm Hotel, which was then only partly built. A day or two after we arrived, a gray-haired gentleman in the dining room came over and spoke to Grandmother. He was Henry M. Flagler, who had been an usher at her wedding. He suggested that we go with him to Nassau, where he was to buy some property.

So it happened that I got in Nassau my first glimpse of the tropics - an iron which entered so deeply into my soul that it is still completely embedded. The specimens of snakes and lizards which I secured at that time became the nucleus of my own collection and are now part of the collections of the Museum of Comparative Zoology at Harvard. Imagine a timid, introspective youngster thrown, at the most impressionable moment of his life, into the one spot most ideally framed to arouse imagination to the fullest. Grandmother was as keen as I to sail over the Sea Gardens and peer at their wonders through a water glass. I don't remember glass-bottomed boats in Nassau at this early date. We sailed among the little cays which surround New Providence Island, picniclied, and collected shells. 
Grandmother made herself extremely unpopular by collecting and taking back with her to Eau Gallie one John Sumpter, who had been Lady Blake's gardener - and Sir Henry Blake was Governor of the Bahamas. He took care of her garden till he died.

I can thank Grandmother for starting me on the road to being a naturalist - she was the only member of the family who thoroughly encouraged me all the time. Father and Mother were perfectly fair and believed that I had the right to decide about my own career, but they were utterly unenthusiastic. I think the only time Father ever came to the University Museum - it must have been early in my freshman year - he walked up to Alexander Agassiz and asked if he knew where I could be found. At this time, of course, Mr. Agassiz didn't know me from Adam. But he asked Father, "What is your son interested in?" and Father answered, "Pickling toads." So Mr. Agassiz steered him down to Samuel Garman's quarters where he found me.

I was no stranger to the Museum, for the reason that I had been previously under the spell of an ardent lover of Harvard, Theodore W. Moses of Exeter. Dr. Moses, a friend of my father, tutored me when I had trouble at school because of an attack of typhoid fever which knocked me flat in the middle of the school year. He asked Father to allow him to take me to Cambridge when he went up for his twenty-fifth reunion in June $\mathrm{i} 899$. I had been destined for Princeton, but this visit to Cambridge changed the course of my life. I did not want to listen to the tiresome speeches on the afternoon of Commencement Day, so I sneaked off and visited the Museum. Here I wandered 
alone for hours, completely entranced. I had been of ten to the natural history museums in New York and Washington, but here was something entirely different, and I soon discovered that this was essentially a museum for the edification of naturalists rather than for the great urban public which the museum in New York had to cater to.

I spotted some specimens which I thought were wrongly labeled - and as a matter of fact they were. I wrote with all the dignity of my thirteen years to Dr. Woodworth, then Acting Custodian of the Museum, who was rather infuriated by my temerity. As I look back on it, I don't blame him. I suspect that my letter was as fresh as green paint. I made up my mind that very day that if I lived I would be Director of the Museum. I had to wait until 1927. Mr. Lowell wanted me to take office earlier, but I begged him not to push matters. I was perfectly willing to wait out of consideration for my predecessor. No consideration was ever more completely wasted, or more ill-conceived, for my predecessor left the Museum in a huff and never entered it again or spoke to me as long as he lived - and he lived to the ripe old age of ninety-one.

I came to college as complete a social misfit as ever breathed. I was abnormally shy, suffered from a bad inferiority complex, was tall and gangling. But fortune favored me. I had spent the summer of r 90 i at a boys' camp near Bridgewater, New Hampshire. There I had a wonderful time puttering with a tiny museum of natural history and writing a list of the reptiles of New Hampshire and something of their habits. Dr. Glover M. Allen had been a counselor in this camp the year before, and in some way I 
learned that he was a kind and friendly person. So he proved to be.

When I came to college I chose a room in the corner of Conant Hall, because there was no place where I could be nearer the Museum. I chose Professor Robert T. Jackson as my Freshman Adviser, to my great good fortune, for he and I have been good friends from that day to this. I soon found that Allen roomed in Perkins Hall, directly across Oxford Street from my lodgings, and as soon as I was settled and had an evening clear, I went over and knocked at the door of 28 Perkins Hall. I found him and his roommate, Austin H. Clark, both at home and introduced myself. One thing led to another. Austin Clark introduced me to Garman in the Museum. Allen introduced me to Henry B. Bigelow, who was preparing to take his doctor's degree, as was Glover. Gradually I found myself at least a tolerated member of a small congenial group of men of the highest intellectual quality, whose conversation was infinitely more enlightening and educational than most of the courses which I took during my not particularly distinguished undergraduate career.

It was while I was in college that my brother Warren contracted tuberculosis and Dr. Trudeau cured him at Saranac. Then he advised Warren to go to Bermuda for the winter. I joined him for the Christmas holidays. As usual, I was infatuated with the chance to collect. The coral reefs at Hungry Bay were easily reached at low tide, and everything was new and enchanting.

I stayed in Bermuda long after I should have been back in Cambridge. On my return I got more or less caught up, but my marks were not very good. The next spring Dr. 
Bigelow and I went to Bermuda with Professor Mark to open the Bermuda Biological Station for Research, an organization which still exists. While in Bermuda on this second trip I got word that Professor Shaler had done the unprecedented and had given me a D in Geology 4. This made me a dropped freshman when I returned to college, and I had to report like a convict on parole to Dean George H. Chase. Then I began to work at my studies. Next term I was again in good standing and got good marks for the rest of my undergraduate years. But when the time came to take my A.B. degree I asked the registrar, Mr. George Washington Cram, whether it could not be granted cum laude as I had the requisite number of A's and B's. I found, however, that my sins were not to be forgiven me, and I got no such thing.

I did not take my A.M. until after I had come back from the East Indies, nor my Ph.D. until after I had been to South America as a member of the North American delegation to the First Pan-American Scientific Congress, held at Santiago, Chile, in 1908. Professor Archibald Cary Coolidge was a member of our delegation. Probably I should never have met him if we had not been thrown together in this way, for I took no history or economics, or indeed anything, during those days of free electives, except zoology, botany, and languages. Archie and his secretary, Clarence Hay, became dear and valued friends.

On the Santiago trip, Archie would come up to me at sea with two pads and pencils and we would see how quickly we could write down the names of the nineteen provinces of China or the twenty-three states of Mexico, or bound the province of Uganda or Togoland, or name 
the Grenadine Islands. It was good practice in learning geography, and a knowledge of geography is infinitely useful to a museologist. I don't say that I always won at these games, but I held my own pretty well, and Archie made me feel proud by saying that he had never known any other person who knew so many place names and their location. It was simply the vagary of a peculiar type of memory. But this, with an ability to remember the names of animals, thousands and thousands of them, has been useful; and I have more luck in holding onto the names of more different kinds of animals than anyone I have ever met. I feel perfectly certain, however, that my friend Elmer Merrill can name more plants at a glance than I can animals.

While I was an undergraduate I was too shy to make any friends among my classmates. I came to know some of them very well later on, I am proud to say, the most distinguished of them being Herbert Winlock, noted Egyptologist and former Director of the Metropolitan Museum of Art in New York. I literally did not know that there were any such things as clubs in Cambridge. I had heard some names, but they meant nothing to me. I joined the Harvard Natural History Society and attended its meetings quite faithfully, becoming president in my senior year. Many years later I was made an Honorary Member of the Signet and was much touched at the compliment, as I was when elected an Honorary Member of Phi Beta Kappa. 


\section{CHAPTER IV \\ "For Richer for Poorer"}

EvEN before I entered Harvard, one of the greatest stimulants to my career had come to me in the course of my schoolboy visits to the New York Zoological Park, where I used to spend my Saturdays. I knew Professor Henry Fairfield Osborn, the President of the Zoological Society, because one of his sons was a schoolmate of mine. To me, a shy fifteen-year-older in those days, he seemed very awesome, but one Saturday afternoon he did something which enriched my life more than he ever realized. On this occasion he sat down beside me in the train going back from the Bronx to Grand Central Station. He asked me what I had been reading and then said, "There are four great books for boys who like natural history." And he named them: Wallace's Malay Arcbipelago, Belt's The Naturalist in Nicaragua, Bates's book on the Amazon, and Hudson's on the La Plata region. Well, I read them in this order. Wallace's book, coming first, made the greatest impression; I read it over and over again until I knew it almost by heart. And my desire to see the Dutch East Indies became so all-consuming that I must have seemed a veritable monomaniac to my parents.

I was married on the first of October, 1906. When I had won a yes from Rosamond, in the face of countless competitors, I soft-pedaled the fact that I planned to leave for the Dutch East Indies as soon as we were married. This 

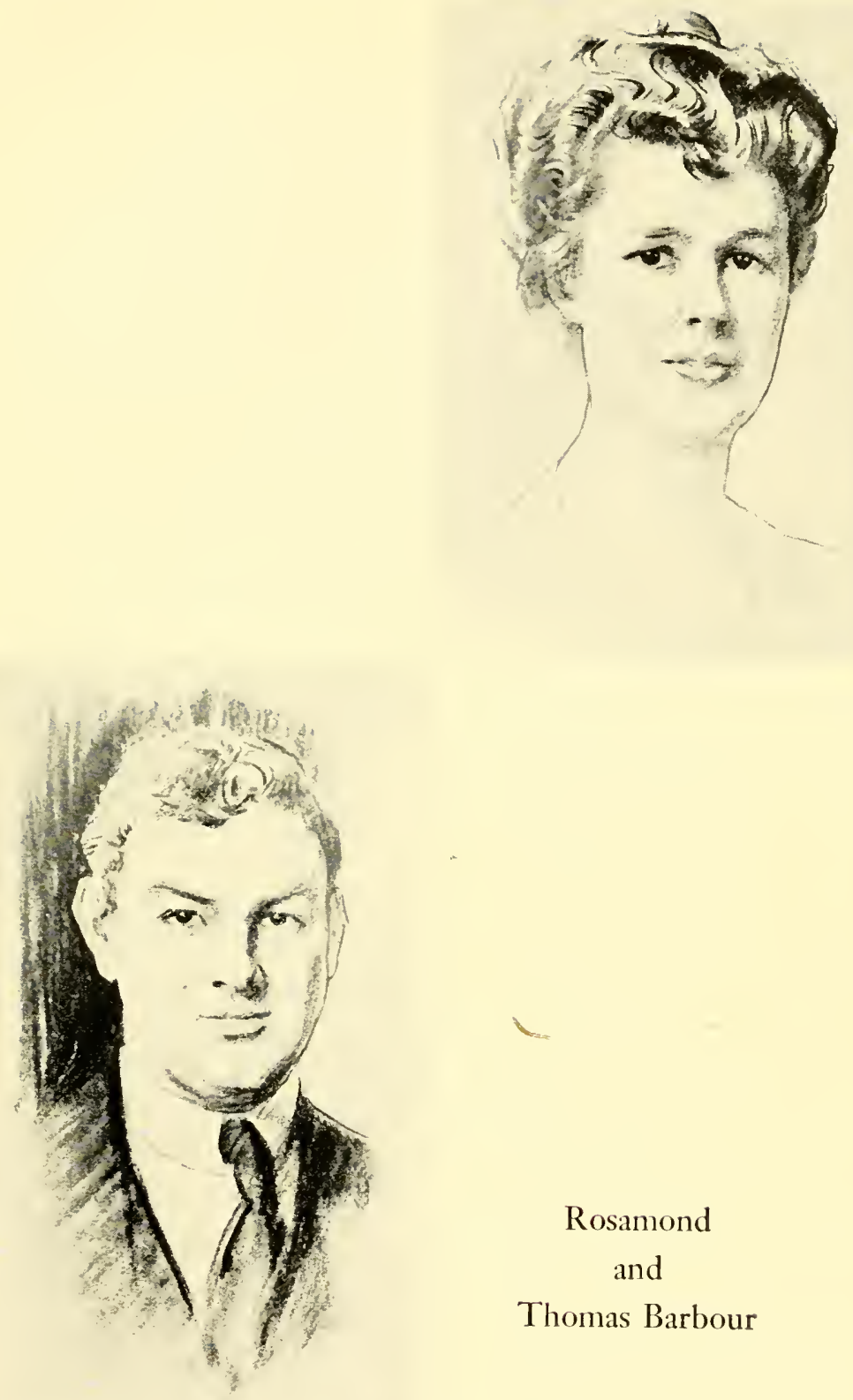

Rosamond and

Thomas Barbour

By Jobn Singer Sargent, 1919 

news, when it broke, caused a bit of a surprise. My wife had once been west of the Adirondacks, once south to New York, and once north to North Haven.

She had lived in Brookline, surrounded by untold cohorts of Bowditches, Higginsons, and Cabots, all kin, and many of them what in Charleston would be called "kissin' kin." I do not have to enlarge upon the fact that she is a strongminded and masterful person; if you belong in these clans you are that automatically. I cry at funerals and at movies and at certain types of music, particularly "The Flowers of the Forest" on a good pipes band. She always has her emotions completely in hand. She is as bold and daring, especially in facing misfortune, as I am shrinking and cowardly.

The day after Rosamond and I were married we sailed on the Ivernia for Queenstown. My father's family came from Northern Ireland, and in 1906 a number of his uncles were still alive and were keen to have a look at my bride. I cannot remember now which one gave the party, but a celebration was staged in honor of our arrival. A big barrel of Jamieson's, not too old, was put out on the lawn for the benefit of all and sundry. The next day I met Danny Ferris, one of the gardeners, and asked him if he had had a good time. He said, "Oh, God, Mr. Tommy, I could neither stand up, nor sit down, nor roll on the ground." He must have been really tight. Pat Dooley told me that his wife had bitten him. And he added, "I was only bit but twice in me life, once by me ass and once by me woman. And yesterday I wished to God the ass had swallowed me."

My Uncle James's two old gardeners, bosom friends, 
walked down the road after the party, one saying to the other, "Don't say it," and the other muttering, "I must! I must!" This was repeated over and over again until one blurted out, "To hell with King William." And his colleague, who was a Protestant, promptly picked up a cobblestone, knocked him on the head, and kicked him into the gutter. For those are fighting words indeed in that lovely land.

The blame for the fighting is evenly divided. On the anniversary of the Battle of the Boyne the Orangemen parade with the whole idea of insulting their Catholic neighbors. They sing: -

Teeter, totter, milk and water,

Slaughter the Catholics every one;

We will take them to battle

And kill them like cattle,

And pile them up under

The Protestant's drum.

Of course preparation has been duly made and the housetops are well piled with cobblestones and brickbats. The great Linen Thread Works, which have been operated by my family since the middle of the eighteenth century, expect to close down for a few days twice each year - once after the anniversary of the Battle of the Boyne and again after St. Patrick's Day.

Father told a story which well illustrates the unbelievable agility of the Hibernian mind. It ran something like this: -

Ireland is a rainy country, but there are spells of dry weather. At such times an elderly retainer was employed 
to bring water from a pond near by for the garden or for sprinkling the driveway. Father asked this old man in a bantering way what capacity his cart had. The old man told him. "How many trips do you have to make in the course of a year?" And the old man told him how many. "Well," said Father, "I have a sovereign for you if you can figure out how many gallons of water you haul from one end of the season to the other." "Oh," replied the old man, "that's too easy. I haul all the water you don't see in that pond there now."

We are inclined to laugh at the Irish, to be impatient with them sometimes, but deep in our hearts we love them and admire them for their bravery, their loyalty, their love of poetry and flowers, their kindness to animals, and their unfailingly warm hearts. In the words of the old song, "Who then can blame us if Ireland is famous for murther and whiskey and beauty and love?"

After our visit to Ireland, we crossed over to London for a few days before taking the express from Calais to Brindisi to catch the boat for Egypt. At London I went to the office of Thomas Cook and bought a skeleton ticket which covered a good many of the inevitable steamship runs, such as Port Said to Aden, Aden to Bombay, Calcutta to Rangoon, Yokohama to San Francisco. This consisted of a mass of coupons pinned together which were to be exchanged for steamship tickets. These coupons I inadvertently put in Rosamond's trunk. Then this trunk caused our first marital argument. It was a veritable leviathan of a trunk. I have never seen another one so large. I said, "Buy ten little trunks that can be easily handled and let's ship that white elephant of yours home." 
Rosamond finally agreed. Our warm clothing and heavy overcoats, which we had needed for the North Atlantic crossing and were not likely to need again, and sundry purchases made in England filled it up. Father's agents in London arranged to handle its transfer to Boston, and I mailed the key about two hours before train time. Just as we were ready to leave for the station, it occurred to me that all those coupons were in the trunk. I rushed downstairs in a frenzy. In the old Metropole Hotel, where this affair took place, there was a letter box right by the door of the elevator. By inexpressible good fortune I reached the bottom step just as the postman, key in hand, was unlocking the box. I spotted the letter and made a grab for it, pushed a half sovereign into the bewildered postman's palm, and jumped for the elevator. Before the postman could yell "Stop thief," I had the key extracted. We just made the train.

By nature I am a timorous person. Physical bravery is no part of my make-up and all my life I have dodged trouble rather than looked for it. For this reason, while I have traveled a good deal, I have few adventures to recount. My friends often counter with the statement, "But you catch poisonous snakes with your hands." This, of course, is only partially true. You need the right sort of stick and then, when you know how, picking up snakes, whether harmless or poisonous, is no trick at all.

My wife and I, however, made one trip in 1906 which for some reason was crowded with thrills. A family friend, Sir Frederick Palmer, Chief Engineer of the Port of Calcutta Authority, gave us one of the Survey vessels for a 
trip to the Sunderbunds. At certain times of the year, when the water is high, the shifting sands of the Hooghly River make it necessary to revise pilot charts every few days, and a number of vessels are constantly employed in this work. But in the dry season they are not so busy, and one was available for our use.

We sailed from Calcutta down into the vast network of waterways which make up the double delta, for the Hooghly River and the Brahmaputra River flow into the Bay of Bengal near together. This region, called the Sunderbunds, is a maze of islands, and at low water each of these is fringed by wide marginal flats grown with grass and bushes, which are flooded at the height of the rainy season.

On these open maidans, as they are called, the axis deer, or chital, swarm at night to graze. Tigers abound and feed on the chital, and there is an abundance of wild life of other sorts. We spent several nights in a machan, a platform high in a tree, with tethered goat for bait. We wanted to kill a tiger, but there was too much wild food about, and while we saw fresh tracks and heard tigers, we never saw one.

Late one morning, after we had slept for some hours following our night's vigil, I took my net and Rosamond her box of papers, and we set to collecting butterflies. There were clumps of flowering shrubs three or four feet high, the plants looking something like our buttonbush. A good many butterflies were coming to these flowers, and the collecting was good. A boy followed us with my double-barreled Manton Express rifle on his shoulder. I looked back to speak to him for some reason, and saw that he had 
disappeared. Just then a perfectly magnificent tiger walked out from one of these clumps of bushes and stalked away over the open grass as if he were crossing a lawn, his tail straight in the air, its tip flicking from side to side. Since there was no particular object in running away, nor any place to run to, we stood and watched him walk majestically out of sight behind another thicket.

A few days later the captain of our little vessel went out with us to get some snipe for the pot. We got widely separated, and I heard him shoot from time to time, but naturally I paid no particular attention. Later on, circling about to return to our meeting place, I heard a snort, and a giant wild boar which he had wounded charged me on three legs with an unbelievable alacrity. I realized, however, that I held a deadly weapon in my hand if I only shot straight. I waited until he was about ten feet away and then put a charge of snipe-shot straight in the middle of his forehead. He fell dead and skidded almost to my feet. The charge of shot entered his skull like a solid slug, and the pressure on his brain popped out both his eyes, so that they hung by their optic nerves. He never moved. Then our gunbearer turned out to be a Mohammedan, so I had to skin out the saddle and hindquarters and carry them back to the boat. Luckily we had a Hindu cook of a caste which allowed him to handle pig. In due scason we dined sumptuously.

The third event - and mind you, all this happened within ten days - almost ended tragically. I was standing in a flat skiff called a panchi, the butt of my double-barreled Express rifle resting on the thwart in front of me. The search- 
light of our boat played on a group of chital, and I was being paddled up under the beam of light with the idea of shooting one. The skiff hit a submerged stump, and bounced the stock of the heavy gun off the thwart. As it dropped, the hammers caught. The weight of the gun sprung them enough to fire both barrels.

The great lead slugs passed through my hands as they slid off the barrel of the gun, burning my palms badly, and cut the brim of my pith helmet, curiously enough, without knocking it off. My face was filled with black powder grains. I sat down, considerably shaken, and went back to the boat, where my wife and the captain helped me aboard. The gun.was badly damaged, so there was nothing to do but return to Calcutta, which we did at once, and there Major Camalliri, surgeon of the Coldstream Guards, picked the powder grains out of my face. A few days' rest set everything to rights. In my usual hypochondriacal way, I wasted a lot of mental energy awaiting tetanus, but in due time there was too much else to think about and this nonsense got pushed out of mind.

While Rosamond and I were resting at Darjeeling, after I had pretty nearly blown my head off in the Sunderbunds, we met an interesting character, a Mr. Mueller. He collected all sorts of objects, from Tibetan bronzes to butterflies, and was in touch, by correspondence, with museum directors everywhere. He had for sale some of the material picked up by members of the Younghusband expedition to Lhasa, and Rosamond proceeded to get a few mementos of our visit.

He remarked casually to me that this was the season of 
year when his professional butterfly collectors worked most successfully. These men were Lepchas, a tribe of hillmen from Bhutan who were born naturalists. I had often heard of the wonderful variety of butterflies to be found in the deep tropical valley of the Teesta River.

The upshot was that he agreed to hire for me several of his very best collectors, and Amir Hassein immediately set out to get ponies and supplies. We set forth early one morning, I on a sturdy gray pony, for I was slender and light in those days. Collecting along the road as we went, we arrived at nightfall at the Dak Bungalow near the bridge over the Teesta River.

On this trip I first had a chance to see really fine, high tropical rain forest. I also had my first sight of a troop of monal pheasants with an enormous cock leading his harem across the narrow road-a glittering mass of metallic golden bronze and green, the sun striking his back as he moved proudly on his way. He certainly topped my experience observing wild life up to that moment.

Then, of course, there were many other birds, jungle fowl, and other species of pheasants, and lastly, the butterflies. These were in astonishing variety. The Lepchas were keen as mustard and extraordinarily skillful with their long-handled nets. We caught and papered butterflies until we had a magnificent collection.

After several days of continuous excitement and enjoyment we returned to Darjeeling, where I joined Rosamond, who was waiting for me there. I supplemented the collection we had made ourselves with material purchased from our friend Mr. Mueller and sent the whole collection back 
to the Museum. There, by the most inexcusable carelessness, it was mislaid and so badly eaten by Dermestes that few of the specimens ever finally reached the collection.

At Lucknow, in India, we went out to a village with a friend of our bearer, Amir Hassein. This friend lived in a village within easy driving distance. Amir had spoken of the fact that his master (meaning me) was obviously crazy, as he was interested in snakes and other loathsome creatures. It seemed that a giant cobra lived in an abandoned rodent burrow near a path between the friend's village and a stream where the women went to draw water. In passing along this way at night, because it was cooler then, several people had trod on this cobra. Only a few days before, a child had been bitten and had died.

Now of course they could not kill the cobra. You remember that when Buddha was asleep under the Bo tree, the cobra came up and spread its hood to shade his sleeping eyes. The Master blessed the cobra then; and if you don't believe it, how do you explain the fact that the two finger marks are to be seen on the cobra's hood? So naturally the cobra is sacred, and no native was going to risk his prospects of the hereafter by killing it. But no one cared a rap about my chances in the hereafter, and if I killed the cobra, so much the better.

We trudged out across the dusty plain and came at last to the little hole where the villagers said the cobra lived. I had an old entrenching tool which I used to dig insects out of rotten logs, and with this I commenced to enlarge the hole, cutting down in the hard-baked earth. I got down about a foot before I saw what was obviously skin of either 
a lizard or a snake. I strongly suspected snake. I gave it a polke with the tip of my digger and out came the most magnificent cobra you ever saw.

We subsequently preserved any number of them for specimens, but none so "manner-gorgeous" as this one. It came out, reared up, its beady eyes peering from side to side as it moved its head inquiringly, its tongue flashing. I had to have a picture of it. I had no long-focus camera in those days and I wanted a picture of this cobra which would fill the whole plate. I got it (I have the picture framed on my wall at this moment) by lying down on the ground and edging up until I was right in front of the snake. My wife stood by with an open parasol, and when he saw fit to make a nip at the camera, which meant coming pretty close to my face and hands, she would lower the parasol in front of him and he would sway back and straighten up again. I took a number of excellent snapshots and then carefully shot the snake with a charge of dust-shot in a .38 cartridge so as to damage him as little as possible.

We got an earthenware jar from the village near by, coiled our treasure down in it, and went back to Lucknow. Rosamond refused to have the snake in our room because, as she wisely maintained, snakes have a way of coming to life after they have apparently been killed. The upshot was that a jackal sneaked up on the low clay porch in front of the room and carried off the cobra while we were having supper. But I still have the photograph, and I am still just as convinced as I was then that I am fortunate in having a wife who is not only beautiful but brave. I had stepped into great good fortune.

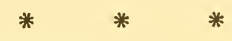



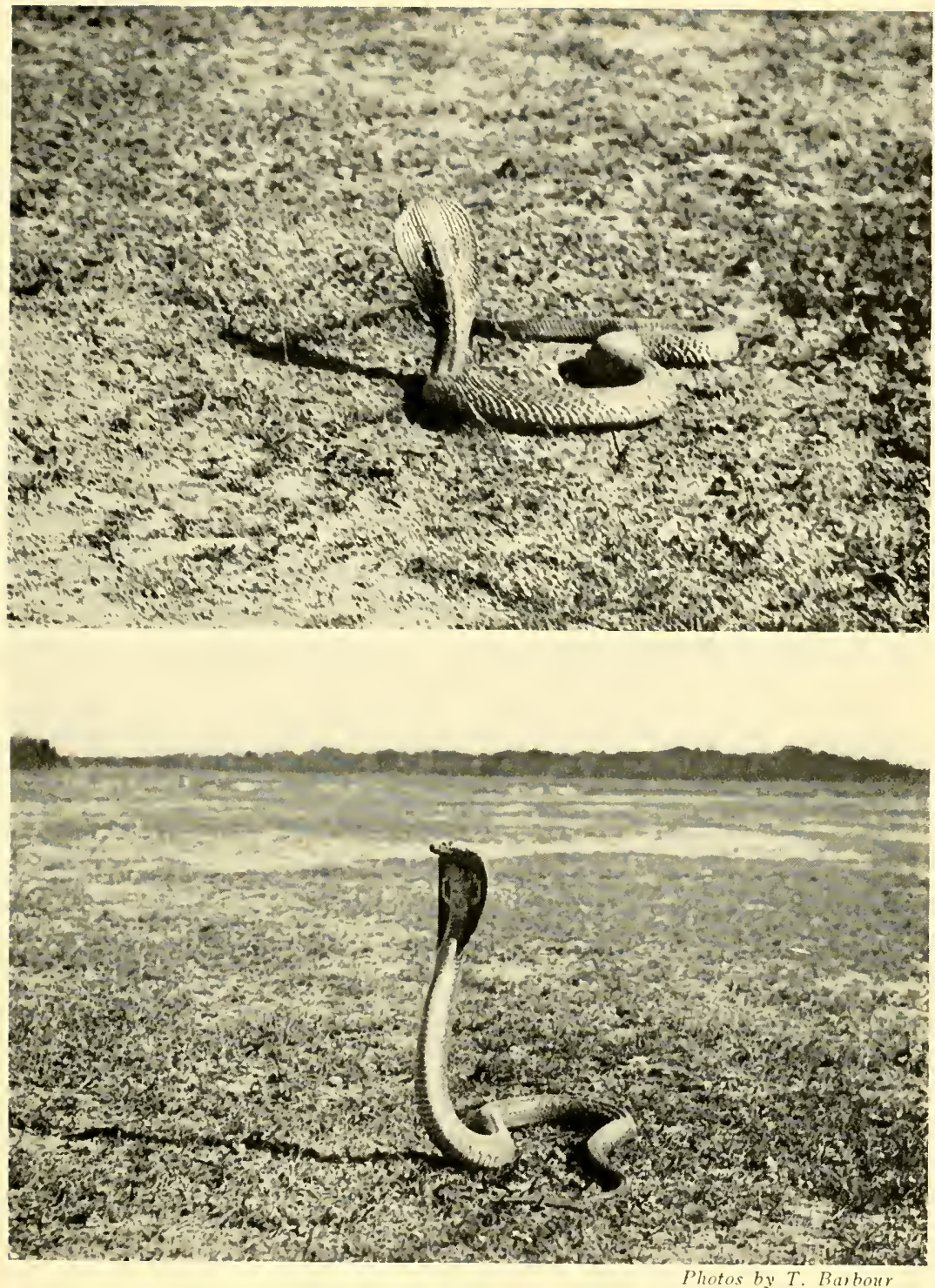

The big cobra killed near Lucknow on the fifteenth of November, 1906 

Forty years ago India was a travelers' Mecca, but relatively few thought Burma worth more than a glance. They would sail from Calcutta to Rangoon, look at the great pagoda, rush up to Mandalay and see the sights of the city, interesting enough to be sure, and then call it a day and move on. We decided to do a little differently.

We crossed from Calcutta to Mandalay and found something which I have never forgotten and which really whetted our appetites for more. This was not Shwe-Dagon, astounding as that great temple is, but rather a row of big trees of Amberstia nobilis encircling the lake in the city park. Amherstia is certainly the A number I flowering tree of the whole world and this is its homeland. The individual blossoms look like tiny hummingbirds each mounted on a slender wire and all tied into a long dropping cord, so that the dozen or more little birdlike flowers stick out quite evenly in all directions. The individual blooms are scarlet with big blobs of gold symmetrically placed and as sharply defined as if each one were hand-painted. The foliage of the tree, especially the new shoots, is delicately tinted, and with the leaves makes up a combination of color and form which is superb. After driving out repeatedly to look at the Amherstias, we decided to postpone our trip to Java, where we had a real job to do, in order to see a little more of this fascinating country. For the more we heard of it the more we wanted to see. And naturally we took time to watch the elephants a-pilin' teak and all that sort of thing while we were making plans. Late one afternoon a comfortable train landed us in Mandalay, where we did the ordinary sightseeing of palaces and shrines. Rosamond reveled in the silk market and I went 
snipe shooting: snipe were plentiful in the rice fields and the sport was excellent.

Comfortable and reasonably rapid express steamers carried the mails from Mandalay to the head of navigation on the Irrawaddy, and on these most of the few visitors desiring to take the trip usually traveled. We, however, to our great good fortune, found that the Irrawaddy Flotilla Company was planning to send a bazaar boat up the river in a few days and that this would offer a comfortable and leisurely way to see this long stretch of water. My wife has never had much inclination to explore, so that this was a compromise proposition. Because I have had few trips of this sort, this pleasant river trip probably looms larger in my memory than it would have done otherwise. Nevertheless, since no American will take it again for many a long day, some of the high lights may be worth setting forth.

The boat on which we traveled was like a gigantic pumpkin seed with a great stern wheel. She had a fine upper deck giving forward, an airy dining room and quite comfortable cabins, with the beds well screened. She was built to draw very little water because the river is shallow and the bars shift constantly. Lashed alongside was an even larger flatboat or scow, roofed over but with open sides. On this great barge space was rented out to merchants who sold almost everything. This meant that we traveled slowly, did not run at night, and tied up at innumerable little villages where the people on shore would come piling down to bargain and chaffer with the merchants on board the flat. We had time for many pleasant walks in the woods, for opportunities to observe birds and animals, and even 
the chance to do a little collecting of reptiles, although the season was unfavorably dry. Occasionally, moreover, we shot ducks to vary our everlasting diet of curry, and we did pick up a fair number of lizards and the like.

Rosamond had a regular busman's holiday when we stopped at Thaybeitkyin, which is the river port for Mogoc where the famous ruby fields are located. Of course the officials in charge of the mines take great care to see that bootlegging of rubies does not take place; nevertheless, the natives are very shrewd and it is possible to pick up tiny but lovely colored stones at low rates. And this place was sufficiently remote so that there was little danger of having imitation stones offered to us.

We stopped in many strange little towns. I remember particularly Mingoon, where there is the largest hanging bell in the world. (The great bell in Moscow is a little larger but has a chunk knocked out of it and it is set down on the pavement in the city.) The great bell at Mingoon is about two feet clear of the ground and as you creep under it and look up twelve feet or more into the beautiful polished inner surface, you can but wonder what would happen if it dropped while you were inside. In the East great belis are usually struck with staghorns or with a heavy billet of teakwood hung in the middle with a tail of rope that you can haul back and then let go. The noise is not overwhelming when you are right beside the bell, but it is tremendously impressive at the distance of a mile or so.

One day while sitting on the lower deck - and this was but a few inches above the water level - away out ahead I could see a good-sized snake swimming out from shore. I figured that we should probably meet at the rate we both 
were traveling. I seized a broom handle or something of the sort-I may even have snatched him up with my hand - anyway he came right alongside the bow as we went by and I pitched him up on the deck. He was a lovely iridescent Burmese python about seven feet long, skin freshly shed and an ideal size to preserve. Most specimens are enormous and require too much alcohol. I had no container on board which would hold this fellow, so I put him in a pillowcase and kept him in my room until we got back to Mandalay. Rarely will a snake strike while in a bag and if he does his fine needlelike teeth will catch in the fabric and indeed often fetch loose. This fellow as usual made no attempt to escape. He rests in the museum at Cambridge to this day as a souvenir of our journey.

I think that the most amusing sight we saw was one which was repeated on a number of occasions. This was a chance to watch the enormous droves of macaque monkeys working along the riverbank. They moved slowly along, industriously turning over stones, pulling sticks and logs about, the old individuals appearing very serious, while the myriad youngsters gamboled about the tree tops over the heads of the traveling band. Every once in a while a young monkey would come down and sit on a branch which was near the ground, and waiting for the crowd to pass beneath him would seize one of the elders by the tail and give it a mighty twitch. This would set all hands to scolding and bickering and chasing one another, as punishment was passed out down the line.

Once we saw a smallish elephant come down to drink and once up near Katha a giant cow. This big elephant was so tame and paid so little attention to our clumsy- 
looking flotilla that I thought she must have been a tame elephant which had wandered off from some lumber operation. I found that there was no lumbering going on in the area and that she was unquestionably a wild animal and a very fine one to boot. Birds were a great source of interest - pigeons and paraquets especially - and the occasional pairs of hornbills crossing the river were always impressive. Their heavy wing beats were accompanied by a noise like the puffing of a locomotive on a heavy grade a mile or so away.

In most of the villages there were little monasteries where the yellow-robed Buddhist monks ran what might be called their parochial schools, and of course these people never killed anything. Hence the great Tokkay geckos which lived in the thatched roofs were always undisturbed. Sometimes the monks frowned upon our catching these lizards to preserve them, albeit not very actively. We learned that the gentle monks sitting around in the evening would make pools and gamble moderately on the number of times that these lizards would call, for their name "Tokkay" is taken from the sound which they make, and it is usually repeated from five to nine times at each bout of singing.

The trip ended at Bhamo, where the caravans outfitted and loaded up to carry the goods of British India to Tengyueh or Talifu in China. We were impressed by the handsome mules and by the singularly good-looking muleteers, for these Chinese were tall and sturdy. They were well dressed in blue and their queues, which they all wore in those days, reached down almost to their heels. The people around Bhamo are not Burmese but Kachins, a primitive 
folk, picturesque, rather offish, and dressed gaily in red and blue. We succeeded in getting some of their swords and other artifacts for the Peabody Museum. After leaving Bhamo we slipped downstream, the current carrying us along quite quickly, and in a few days were back again in Mandalay.

This excursion had proved so enjoyable and to our notion so instructive that we decided to try one more Burmese expedition. We had heard of the Gokteik Gorge. This was to be reached by the railroad which runs out into the Shan states. It is from the end of this railroad that the Burma Road runs. We went first to Mamyio, a pleasant hill station, and then on to the gorge where there was a $d d k$ bungalow, just a short distance before the railway ended at Lashio. The last stage of the journey was made in a somewhat primitive railroad coach: I remember finding the sliding door which led into the washroom completely covered, and I mean roo per cent covered, with the largest and most ablebodied cockroaches I have ever seen. They scattered about when they were disturbed but before long crawled back and took up their old roosting places.

The extremely deep Gokteik Gorge through which a stream ran was very narrow and the cliffs which formed its walls were so close together, and both "slantindicular" in the same direction, that the effect was just like being in a cave. We looked up and saw no sky. Here there was an enormous colony of cave swifts of the genus Collocalia, a genus abundant, widespread, multitudinous in species, and distributed all over southeastern Asia and the islands. It is from one species of the genus, in the East Indies, that the nests made of the swifts' dried saliva are gathered to 
make Chinese bird's-nest soup. The owning and leasing of these caves is native high finance.

The country about us swarmed with game. Tracks of bear, deer, and leopard were literally everywhere. I asked my bearer to gather some beaters and we tried a drive, but since the vegetation was so thick and since we could post only one watcher, myself, there was only a small chance that whatever game they moved would come in sight. Plenty of game was moved - of that there was no doubt, as I could hear both it and the excited shouts of our beaters. Unfortunately we saw nothing.

From the bungalow everything which went on in the neighborhood, however, could certainly be heard. It was a little building set up on high posts with a good roof but more or less open on all sides. I knew well the inordinate racket made by peacocks where they were really common, for I had heard them abundantly in Jeypore in India. This was just another place where the constant noise made by the peacocks was well reinforced by numbers of jungle fowl. These wild chickens would crow in the morning with high, shrill calls like those of leghorns multiplied a hundredfold; all these birds saw to it that there was no oversleeping. We got butterflies and some other insects but our Burmese collections were by no means outstanding. We were just loafing and enjoying ourselves to the very fullest.

I shall always think of this country in vivid contrast to India. When we were there, the people were singularly friendly. The wide variety of gay costumes worn by Shans, Kerens, Kachins, and Burmese made up a satisfying variety. The Burmese young men and girls were especially 
gay and attractive to look at. I am sure the universal land clearing has greatly changed those gloriously forested banks.

The variety of native craft both rowed and propelled by sail was a constant source of interest. Some of the boats were beautifully decorated and wonderfully carved. Enormous rafts of teak would come down the river, each with a whole encampment of rivermen housed on their artificial island. Every log of teak was made to float by having bundles of giant dry bamboos lashed fast to its length. These rafts made running at night difficult and dangerous.

Today Rangoon is a ruined city, as is also Mandalay. It must have been impossible to bombard and to bomb these torvns without destroying their superb examples of old Burmese architecture, with the gorgeous teakwork carvings and the strangely ornate roofs. Gone too must be the myriad pagodas, ranging in size from lovely little alabaster structures, which were to be found literally by hundreds around Mandalay, to the great Shwe-Dagon at Rangoon. This temple, plated with gold from top to bottom, looked as high as the Washington Monument, though I suppose it was not. Forty years ago Burma was a land of romance and charm. It is a pity that war had to come to it. 


\section{CHAPTER V}

\section{Wallace and the Dutch East}

\section{I}

N MY pocket at the start of our journey I had the best of all passports to the Dutch East Indies. It was a letter of introduction from Mr. Agassiz to Dr. Treub, the famous botanist, head of the Gardens at Buitenzorg and Minister of Agriculture. After our mild zoological adventures in India and Burma, we finally fetched up in Batavia. Major Ouwens, the charming and friendly director of the Zoological Museum in the Buitenzorg Gardens, passed the word along, and all day streams of men and boys - and girls too, for that matter - lined up either at the museum or at our lodgings near by with hollow joints of giant bamboo carefully plugged with wads of grass and leaves. Each contained a treasure - snakes of countless sorts, frogs, toads, lizards, insects, and fishes. We pickled and shipped unceasingly. I had been for a long time surreptitiously learning Malay, so that when I reached Java I could bicker and bargain, and consequently acquired a great collection very reasonably.

We had some weeks on our hands in Batavia before the trim little steamship Both made one of her three-a-year voyages to the eastern islands of the far-flung empire of Insulindia. After deep cogitation, we had picked out this voyage as offering a chance to see the greatest number of localities mentioned by Wallace. There were numberless voyages to choose from, as the little steamers of the K.P.M. 
(Koninklijke Paketvaart Maatschappij) poked their noses in and out of scores upon scores of out-of-the-way harbors. Finally, on January 24, 1907, we set forth.

Our passage was leisurely, loading and unloading was slow, and there were always letters to be waited for or merchants whose affairs dragged on, as always when one is dealing with Orientals. First came Bali, a very different Bali from the island as it is, or was a short time ago. The Dutch had just conquered it, and the natives were still pretty well unpacified. Then Lombok, chiefly memorable as producing a new toad which I named Bufo cavator. Then Macassar, Buru, Ambon, Ceram, Obi, and lovely Ternate.

Here came a real thrill, for I was stopped in the street one day as my wife and I were preparing to climb up to the Crater Lake. With us were Ah Woo with his butterfly net, Indit and Bandoung, our well-trained Javanese collectors, with shotguns, cloth bags, and a vasculum for carrying the birds. We were stopped by a wizened old Malay man. I can see him now, with a faded blue fez on his head. He said, "I am Ali Wallace." I knew at once that there stood before me Wallace's faithful companion of many years, the boy who not only helped him collect but nursed him when he was sick. We took his photograph and sent it to Wallace when we got home. He wrote me a delightful letter acknowledging it and reminiscing over the time when Ali had saved his life, nursing him through a terrific attack of malaria. This letter I have managed to lose, to my eternal chagrin.

The voyage continued all the way around the great spidery mass of the island of Helmahera, one of the loveliest in all the world. The only rough night I remember 


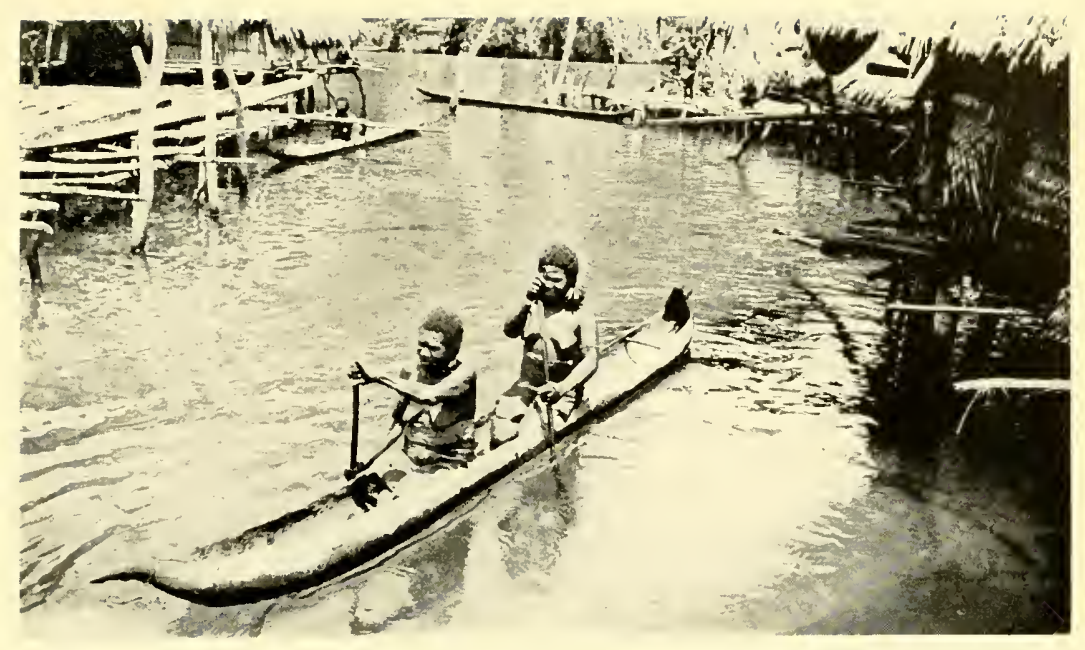

The women's canoe with no outrigger, only used on short journeys

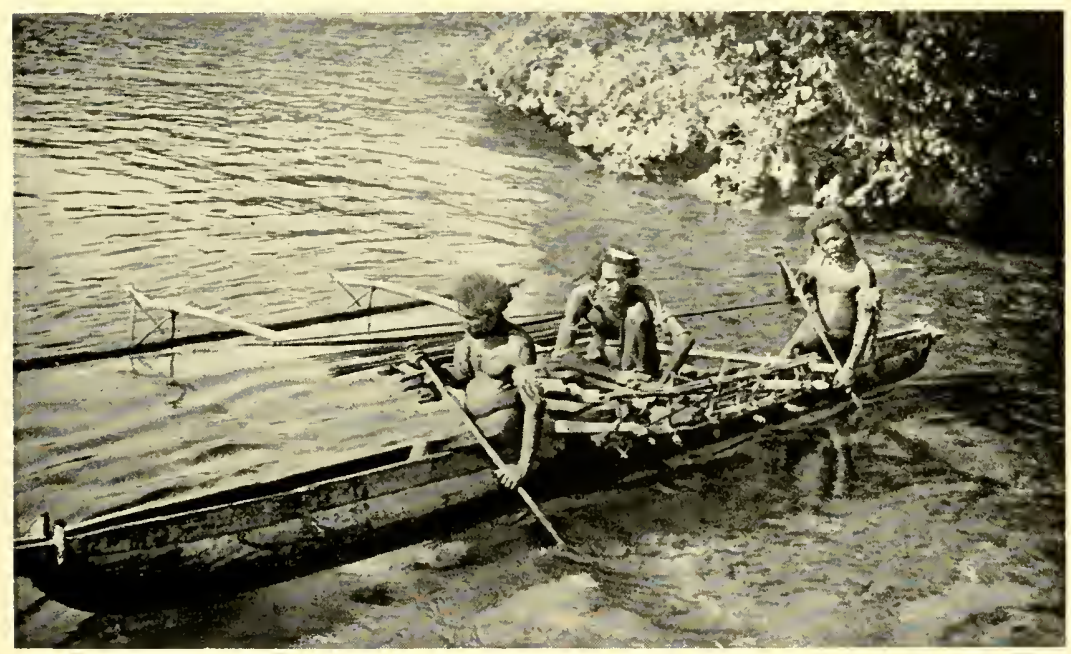

Photos by R. P. Barbour

The men's canoe, used for trips to sea. Humboldt Bay, 1907 

was when we anchored way offshore at Supu Bay. I had been told that we should catch the mischief there, but slept on deck as usual and mighty nearly got rolled overboard before I woke to what was going on. Actually I almost rolled into our meat supply. Since we had no refrigeration, this came on board on the hoof in Bali and stood in a row, tied to the ship's rail. Hitched to the other rail were the Orang nanti (the Chain People, prisoners of war), shackled together. They had been captured by the Dutch in the Achinese war in Sumatra and were going to build roads in Ceram. The fact that the beef had to be butchered on deck - and there was not very much deck at that-meant that my wife sat sewing in the opposite direction, so to speak, waited till she heard the hose which washed the gurry overboard, and then turned about to find the table being set up. The ship's officers and the three or four passengers on board all ate together on the open deck. There was no ice aboard: our meat was fresh for just one day.

The absence of ice made photography difficult. The film of thirty years ago softened easily and disintegrated in warm water. Fresh water on the ship was coolest late at night, so that is when we had to develop our pictures. Some were lost, but luckily we saved the best of them by putting a little formalin in the water to harden the film.

At Ternate we were boarded by a Mr. Sedee, who had agents in numberless little outposts and who dealt in rattan, dammar gum, and bird-of-paradise plumes. He was a mine of information - knew all about Wallace, though he had never actually seen him. And he said one day, "Tomorrow we land in Ake Selaka and there lives Mr. Duiven- 
boden." The next day we found Mr. Duivenboden and were introduced. He was dressed in immaculate white, spoke perfect English. His father had been Wallace's host and his mother a Javanese lady: as a small boy he had seen Wallace and remembered him. He took me into the woods, sat beside me on a giant fallen log, and whistled in a peculiar way. In a few moments, hopping down the long snaky trunk of a climbing palm, appeared a bizarre-looking brown bird. Here was I, sitting at the very spot where Wallace had collected the extroardinary-looking bird of paradise which bears his name. Wallace speaks of the elder Duivenboden as the scion of "an ancient Dutch family, but who was educated in England and speaks our language perfectly." He was a very rich man, possessed many ships and more than a hundred slaves. "He was, moreover, well educated and fond of literature and science - a phenomenon in these regions."

The next day at Galela, a neighboring village and the seat of a rather cocky ruler, as it turned out, I went shooting at dawn. The island fairly swarmed with parrots, lories, and cockatoos of all sorts. I saw a giant cockatoo in the top of a tall tree. I shot it. Down it came, fluttering and flapping through the foliage, to fall at my feet. I picked it up and, to my utter astonishment, dangling from its leg was about eighteen inches of gilt chain. Of course, it had to belong to the Rajah - a favorite pet which had escaped that morning. There was the devil to pay. I paid a considerable amount of hush money, and I never even got the bird.

We had a little launch on board, called by the Malays "Child of the Fireboat" (Anak Kapal Api). When we 
were anchored near shore and she was not needed to tow cargo lighters, we were generously allowed to use her. In her we explored the rivers and bays which studded this extraordinarily indented coastline. The Kali Weda ran inland, twisting and turning for a good many miles behind the town of Weda. The forest here was sumptuously magnificent - great masses of pandans and canes and bamboos along the bank, and then the high woods. At times the little river ran through a green tunnel. We could hear pigs and deer crashing in the underbrush, but never got sight of them.

What we did get, however, were some enormous lizards - they were three feet long - with a great fanlike sail on their backs and tails, like Permian Pelycosaurs in miniature. To my joy, on coming home, I found that this creature was entirely unknown, and I named it for Professor Max Weber of Holland, who had shown a kindly interest in our journey (Hydrosaurus weberi). I cannot for the life of me understand how Wallace missed finding this creature. We took it at Piru in Ceram as well as here, and it was conspicuously different from allies known from the Philippines and Amboina. It is hard to convey to a person who is not a naturalist by profession the extraordinary feeling of satisfaction which overwhelms one at handling a great, conspicuous creature which has hitherto eluded notice by one's colleagues.

Fortunately, we approached New Guinea through the narrow passage between Batanta and Salawatti rather than through the more ample Dampier Strait which afforded Wallace approach, but he was sailing in a schooner. We had steam and could buck the swift current, albeit slowly. 
Wallace said, as he drew near, "I looked with intense interest on those rugged mountains, retreating ridge behind ridge into the interior, where the foot of civilized man had never trod. There was the country of the cassowary and the tree kangaroo, and those dark forests produce the most extraordinary and the most beautiful of the feathered inhabitants of the earth - the varied species of the bird of paradise." Wallace was not given to hyperbolic expression, for he had been collecting commercially in the Indies for years before he approached Papua, and had had his senses somewhat benumbed by a long stay in Amazonia before that.

Think, then, what were the feelings of a youngster just of age, whose previous tropical experience had been a single voyage to the Bahamas and something of India and Burma on the way east. As we moved slowly through the strait, with the billowing mountains of green near at hand, the little villages of thatched huts borne on high stilts by the waterside, catamarans and sailing prows constantly moving along the shore, I was completely overcome. I am ridiculously emotional by nature, and when the first mate, who stood beside me in the bow, pointed ahead and said, "That is Papoea," as the Dutch call New Guinea, a lump which I could hardly swallow came in my throat.

Then followed unforgettable days indeed. Sorong produced a spiny anteater which we kept alive and were able to observe. A dish of ground coconut soon accumulated enough ants, which we thought would keep it happy. They didn't, and I am quite sure now its principal food is earthworms and not insects. The great, bird-winged butterflies of the genus Ornithoptera were abundant. They flew so 


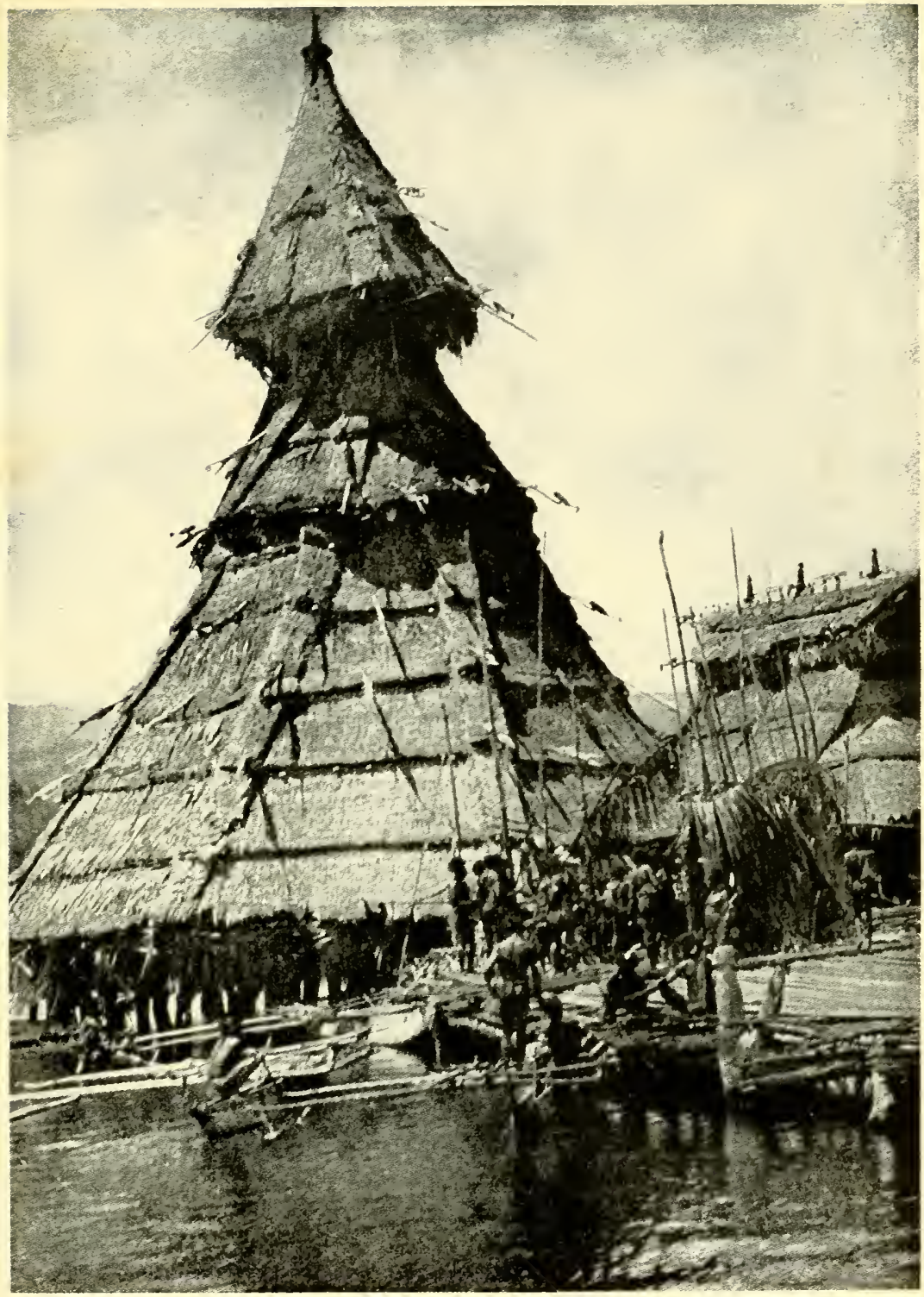

Photo by R. P. Barbour

The Great Karriwarri at Tubadi Village, Humboldt Bay, New Guinea 

high that we shot them with dust-shot and got a good series, which satisfied us entirely until we found a lot of pupae, which we strung up against the curtains of a vacant stateroom. Here they emerged, and we got perfect specimens.

On to Doreh Bay, Wallace's old headquarters. I sent him photographs of the natives here and he wrote me that he was sorry I had, for he disliked them so. They may not have been friendly to him, but they were to us in 1907 , and went with us into the forest. On every fallen log beautiful metallic weevils swarmed, just as they had in Wallace's day, and we had unbelievably good collecting. I came back to the ship one afternoon, Rosamond having been left on board, and found that she had done something for me which touched me greatly. A native had brought aboard a big green snake about four feet long, hitched by rattan fore and aft to a piece of stick. She purchased the snake for a stick of tobacco and a small mirror and then, feeling that it might get away, opened the top of our big alcohol tank, cut the snake loose from the stick, and herself forced the reptile into the pickle. She firmly believed that the snake was a poisonous one. It was not, but hers was a brave and kindly act, since she loathes snakes as much as most people do. And she had garnered the first specimen of Chondropython viridis, which had certainly never before been collected by an American.

By an arrangement with the K.P.M. authorities in Surabaya, we were allowed to delay the itinerary of the Both for a very reasonable indemnity. This, and the fact that Mr. Sedee had much trading to do, gave us a chance to see a good many points of interest along the north coast 
of New Guinea, among them Windessi, where Mr. Van Balen had been immured as a missionary for years. He and Mr. Van Hasselt, located on Mansinam Island in Doreh Bay, were the only Dutchmen in New Guinea at that time. Van Hasselt had tried to translate the Bible into Numfoor, the most widely spoken of the Papuan idioms.

A knowledge of Hawaiian will carry you from Honolulu through all the Polynesian Islands to New Zealand with only a few consonantal changes, but most languages in New Guinea won't carry you across the street, since almost every village speaks its own tongue. I understand Mr. Van Hasselt had to give up his task because the presentation of abstract ideas in Numfoor was utterly impossible. I report this, however, on hearsay.

Pom, Wooi, and Ansus were the towns we visited on Japen Island. Here the natives were distinctly non-co-operative and Ah Woo would not go on shore, saying that too many Chinese had been eaten there in the past. We did try a landing at the little town of Mcosbundi on Wiak Island, but when we went ashore and tried to buy some drums and other objects for the Peabody Museum, we saw the women sneaking off into the thick bush and climbing away up into their little houses set up fifty or sixty feet above the ground. The first officer allowed that this was a bad sign and we had better pull out. And we did, quite obviously just in time, for a cohort of yelling, mopheaded natives thronged the beach. Perhaps they were simply showing off, but the officers of the ship had no desire to encounter the inquiry which would perforce have been held had we been killed, even though we had signed waivers of responsibility before we left Java. 


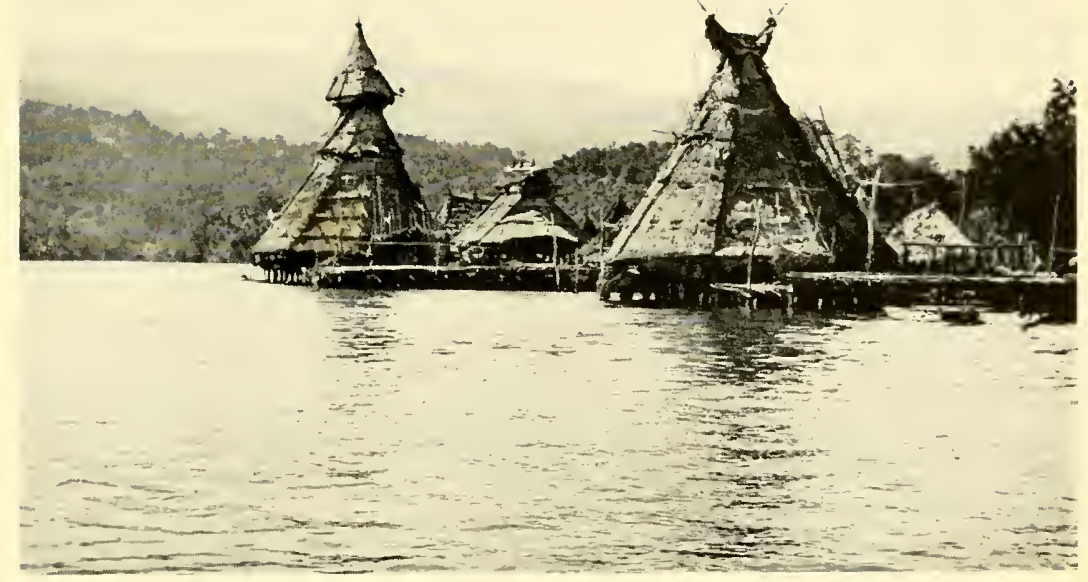

Two Karriwarris at the village of Tubadi in Humboldt Bay

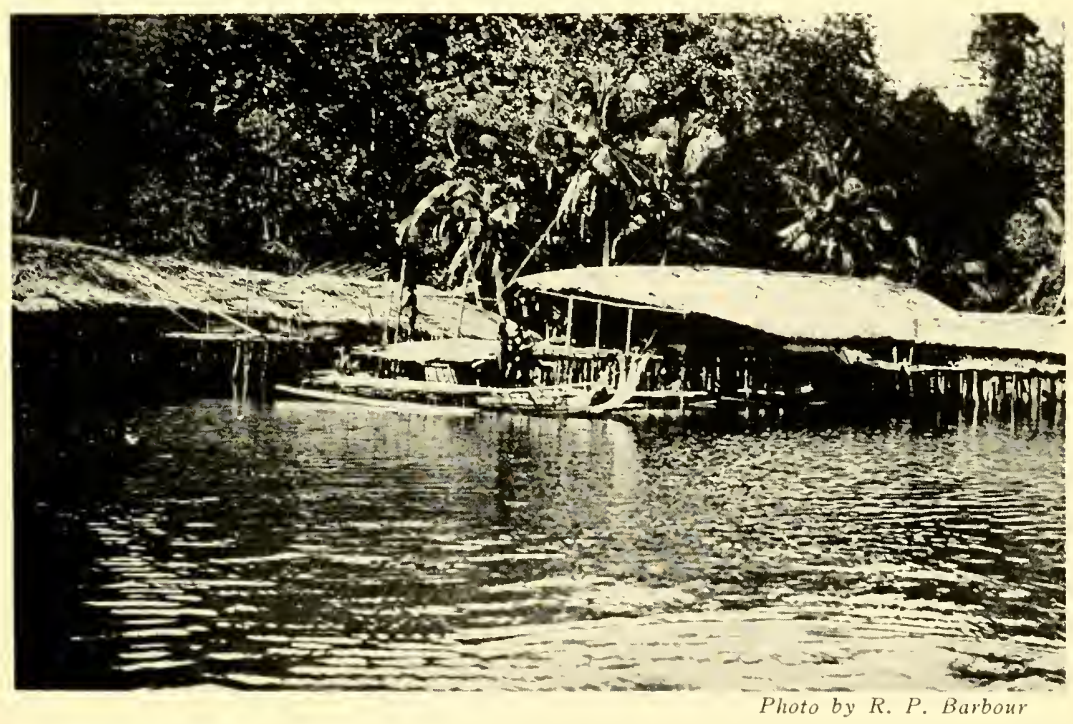

Communal long houses over the water at Ansus, Japen Island, in Geelvink Bay, Dutch New Guinea 

We pushed on to Humboldt Bay, now Fort Hollandia and the base which Richard Archbold used for the great aeroplane which in 1938 carried his expedition to the mountain lakes. Sir John Murray, the oceanographer, told me that when the ship Challenger visited Humboldt Bay in February 1 873, it was absolutely impossible to land. The natives met them with such showers of arrows that they sailed away. We landed on Metu Debi Island in the mouth of the bay amid swarms of natives. We found them stark naked but, on the whole, quite jolly and congenial. They were a little short-tempered if they were crossed, as, for instance, when they somewhat indiscreetly wanted to see whether my wife was white all over. She was the first white woman they had ever seen. In fact, we were so completely disassociated with their idea of human beings that not only at Djamna, but here in the village of Tubadi, she was allowed to enter the Karriwaris, where the sacred paraphernalia are stored. Native women, under pain of death, are forbidden to enter there.

These people were most bizarre in appearance. The women were buxom and not unpleasing in mien; they wore a short skirt of beaten bark shrunk about their waists while the bark was wet and allowed to dry there. In their ears were several dozen rings made of tortoise shell, about four inches in diameter. The whole ear margin was pierced with a row of holes. Their heads were covered with little braids of hair, each weighted, to hold it in place, with a tiny ball of dried clay.

The men wore bands of fiber tightly bound around their arms. In these were stuck flowers or bunches of brightly colored leaves, and often also a dagger, made of a casso- 
wary's thighbone or a human thighbone, chipped to a point. Many carried stone axes, and almost all had bows and bundles of arrows. We photographed their arrow release for Professor E. S. Morse, who was studying the evolution of archery. In their noses they wore the tusks of wild boars, one pushed up through the nostril and through a hole pierced in the side of the nose on each side, a sort of glorified Kaiser's mustache, quite striking when seen from a distance. They wore their hair in great, luxuriant mops, with a comb stuck in it. This was made from the spiny, coarse wing feathers of the cassowary and was used to keep the hair fluffed out symmetrically. They not infrequently wore a band around their brows decorated with hibiscus or other flowers. They either wore no clothes at all or bizarrely shaped little gourds decorated with patterns burned on them, in which a small round hole was cut. All in all, they were highly satisfactory savages and looked just as they should have.

Rosamond and I have been to the Island of Amboina twice, for the Both stopped there for several days on the way to New Guinea and on the return voyage. We went out to Batu Gadja to see the tomb of old Rumphius, ${ }^{1}$ whose

${ }^{1}$ For anyone who may be interested, I can recommend Professor George Sarton's fascinating biographical sketch of Rumphius, who went to Java in 1653 and to Amboina the next year. His drawings were lost there in a disastrous fire on January I I , 1687, but his manuscript was saved. Luckily, Governor General Camphuys had this copied before he sent it to Holland, since the ship Waterland, carrying the original manuscript to the homeland, was sunk by the French. Rumphius continued his work until May 1670, when he completely lost his evesight. 
Ambonsche Rariteitkamer, published in 1705 , first made known to the world the natural wonders of the Moluccas.

A queer old hermit of a Frenchman lived up in the forest not far from where Rumphius was buried. He made a precarious livelihood selling natural-history objects to museums hither and yon. We got a lot of interesting things from him, including a fine batch of cocoons of the local bird-winged butterfly, a giant species, black and metallic velvety green, related to one we had taken in New Guinea and which flew so high, here in Amboina, that we had no luck collecting specimens. We pinned up the cocoons in a vacant stateroom, separate from such others as we had secured so that there would be no mixing of localities, and long before we were back in Java they had emerged and are all now safely pinned out in the collection here in Cambridge.

There was a cave in the hills not far from this same spot. This yielded a few bats of families poorly represented in American collections. But the exciting high light of our visit to Amboina was, of all things, an eel. In 1887 the Reverend B. G. Snow sent some fishes to the Agassiz Museum from Ebon in the Marshall Islands. Amongst these was a single specimen of an extraordinary eel with curious extensions to its nostrils like folded leaves sticking far out

He worked on, helped by friends, and finally died on the fifteenth of June 1702 . He left two great manuscripts, the one I have mentioned and the Herbarinm Amboinense, neither of which was published until after his death. Rumphius was one of the great naturalists of the seventeenth century and he deserves to be better known. Sarton's brief account of his life was written in Isis for August 1937, and a longer and a more elaborate biography will some day be forthcoming. 
in front of its snout. Garman called this astonishing eel Rbinomuraena quaesita. It was long and slender and brown. For some reason or other I remembered exactly how it looked. No second specimen has ever been found, so far as I know.

While frogging about on an Amboina reef at low tide, I saw a sky-blue eel, long and slender and quite active when we rolled over a slab of coral rock. By great good luck I caught it, and in a second I said to myself, "That's another Rhinomuraena and a new one" - and it was. I described it and called it $R$. amboinensis and have it well preserved to this day. No other specimen has ever been reported. Is it not an extraordinary coincidence that the only two examples of this unique eel should both have found their way to Cambridge - one shipped in by the old missionary ship The Morning Star in 1887 , the other found by me exactly twenty years later more than a thousand miles from Ebon?

Our visit to Humboldt Bay was the climax of the trip and our leisurely return a pleasant aftermath. All along the line we picked up objects which had been collected and saved for our return. We stopped at just as many places on the way back as we did going out. Several unexpected delays caused by waiting for dammar gum to be brought down from the interior gave us a chance to garner a great store of ethnological objects for the Peabody $\mathrm{Mu}-$ seum. It was well that we did, for in those days Papua was still unspoiled. Of course, I have lived in hope that by some chance I might once see the interior.

It was at Hong Kong that we met Mr. Daniel Russell of the Imperial Chinese Maritime Customs. He came from 
near Belfast and knew a lot of the members of Father's family, but I think our real bond was the fact that he was translating Bowditch's Practical Navigator into Chinese. He was certainly interested when he found out that "The Navigator" was Rosamond's great-grandfather. He was going to take charge of the customhouse in the great city of Wuchow, a city which had only recently been declared open for foreign commerce. He asked us to join him on the trip upriver. Wuchow is several hundred miles inland from Canton up the west river, or the Si-kiang to give it its proper name. The experience in getting here was a most interesting one and the section of China through which we passed was completely unspoiled.

We journeyed in a small, shallow-draught river steamer, locked in an enormous iron cage. This cage enclosed the bridge, a little dining saloon just aft the bridge, the officers' cabins and a few tiny cubbyholes for passengers, and a small open area of deck. The boat sailed under the British flag; she was spotlessly clean, the food was good. We had several tall, bearded Sikhs and three or four Malays on board, all heavily armed, as guards. All this because the Chinese pirates still abundant in those days used to come aboard a few at a time disguised as passengers, and then, when enough of them had assembled, they would produce their hidden arms and try to take the ship. This was no idle rumor, for even the big passenger steamers from Hong Kong to Canton caged their first-class passengers. It was widely reported that pigtails were interwoven with fishhooks to discourage anyone from trying to make a capture by seizing a pirate's cue.

The country through which we passed was framed in ridges of high hills, with ancient temples and lovely pa- 
godas against the sky line. I don't think we saw a tree during the entire journey. This long-overpopulated land has been deforested for ages and we often saw women out on the river in sampans gleaning sticks and even straws from the flotsam and jetsam of the river for fuel.

The little stern-wheeler on which we traveled made many stops. I remember one place of some importance, Sam Shui, which apparently was greatly famed for its culinary art. Long before we arrived there our Chinese passengers were lined up along the rail licking their chops, and no sooner had we tied up to the bank than swarms of sampans came out, each with one man to row and another to dispense the chow. Each carried a hook on a long rope which they threw up for one of the passengers to hang over the hand rail. The chef stood aft surrounded with innumerable little dishes sizzling over a charcoal brazier like a battery of tiny stoves, and with a big tub of rice, which was the foundation for each meal served. In response to yells from the passengers, he would grab a large, grayish, and rather thick pottery bowl, throw into the bottom of it a handful of rice, and then toss in on top little dabs and gobbets of bean curds, bean sprouts, diced omelette, diced eggplant, fried duck, fried pork from chitlins to diced ears and bits of crisp fried pigskin, white grubs, and what looked like fried angleworms blanched, evidently having been kept in water until they were clear of grit. Not infrequently a little frog would be added, too small even, to my notion, to be worth sucking, but it must be remembered that all food in China has to be prepared for use with chopsticks. As we were leaning over the rail one of the Malay guards said to me, "Sabaya tida mau 

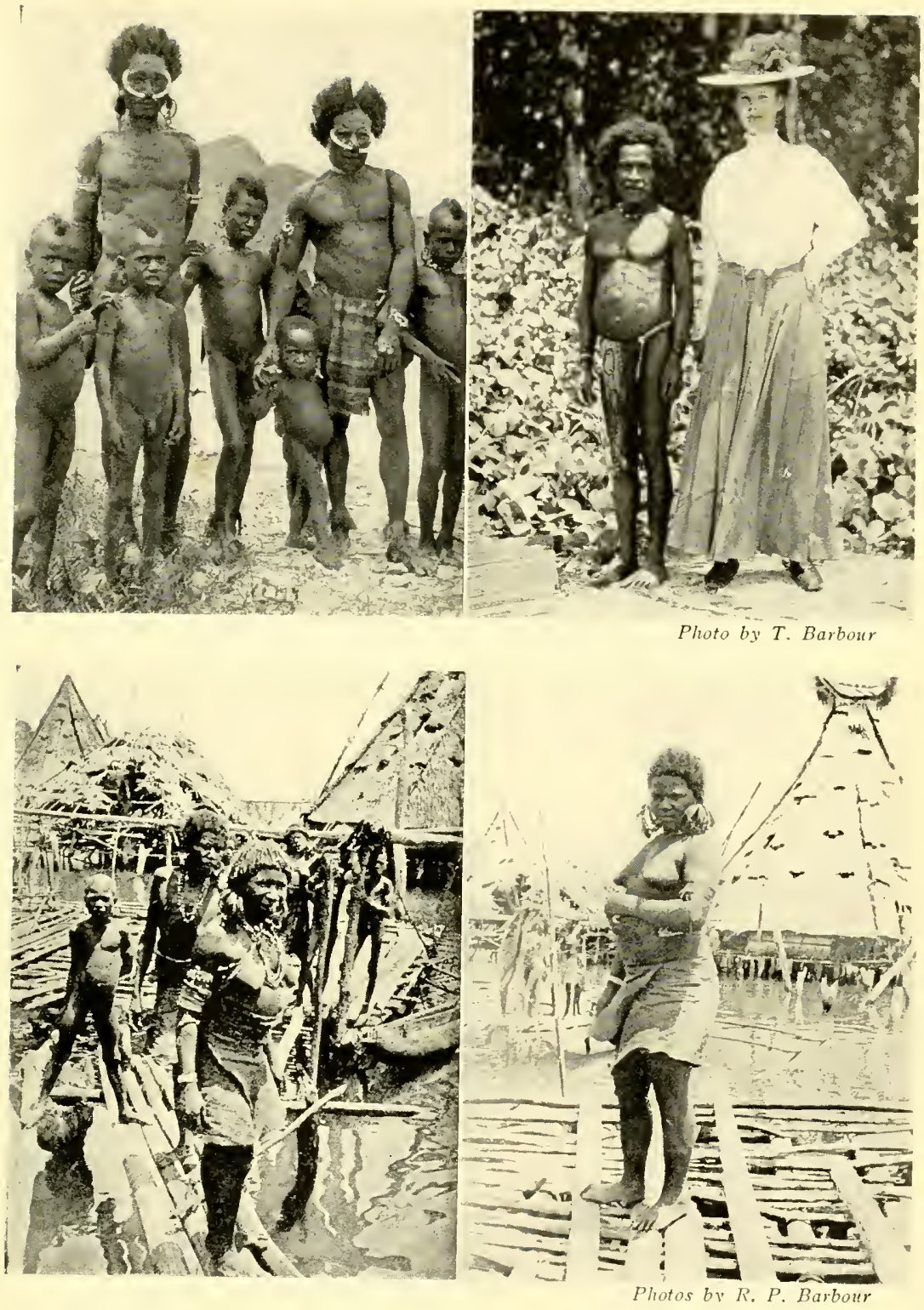

UPPER Right: R. P. B. at Monokwari

other three: Natives of Humboldt Bay 

mackan kodok yang kechil sekali," which indicated not that he was disinclined to eat frogs but rather that he scorned such little ones.

The days passed like winking, the river traffic was so extraordinarily interesting to watch. There were a few steam launches towing barges of all sorts, but more often the boats were propelled by paddle wheels operated by men working treadmills, and how tired the poor devils looked is vivid in my mind's eye to this day. The floating duck ranches and even the occasional great easy-going junks being towed upstream made this journey a vivid picture of Chinese life as it had been since time immemorial. Our little white stern-wheeler Shui Hing was the only foreign note.

Finally we reached Wuchow. Walking about the city was not pleasant. Strangers were too conspicuous and the people did not mind showing their distaste of our presence. However we saw some heart-rending but quite characteristic sights. I remember a woman sitting beside a large pottery jar which had to be set into a niche in the hillside, no doubt the spot which the Fengshui man had told her was auspicious as a burial place, for the jar contained her husband's bones sent back from some far land, and if her grief was not genuine I never saw any that was. China is a land of poverty and sorrow yet the sturdy good qualities of her people have kept her a great nation for a greater length of time than any other nation on earth has been able to survive.

Poor criminals standing in tall tripods with the tips of their toes resting on bricks - the penalty being that if they kicked one over they would strangle-were a frequent 
sight and no one even paused to throw a glance their way. We were told that the previous Tao Tai, not the present incumbent who came to meet Mr. Russell, for he seemed to be a kindly old gentleman, had often snipped off criminals' eyelids and then blew quicklime into their eyes before they were put into the tripod. The collar was made large enough so that their hands could not get to their faces. Of course everywhere in China at the time of which I write, criminals were seen walking about wearing the cangue, a great broad wooden collar, sometimes very heavy, on which their sins were detailed in large painted characters.

Mr. Russell spoke mandarin Chinese fluently but the Tao Tai came from the Province of Fokien and, as our friend said, had "a thick Fuchow manner of speech," so that they did not chin glibly one with the other; however, Mr. Russell gleaned the impression that the old gentleman had some pirates in a cage uptown and he would gladly have them trundled down to the beach and have their heads chopped off for our delectation. Rosamond thought we could pass this up and I agreed.

We lived on board the boat, which was tied up to the riverbank. I have no doubt we could have found a Chinese inn but the city was an extraordinarily stinking and filthy one, although far from ugly when seen from a distance. It had obviously been a place of great importance and I think at one time was the capital of the Province of Kwangsi. At this time, however, Nanning was the capital. Unfortunately the river was too low for us to get up there so, bidding good-bye to our friend, with whom for years I carried on a desultóry correspondence, we slipped back 
down river to Canton. Thus ended a journey memorable to be sure, but as different in every fundamental detail from our voyage to the head of the Irrawaddy as any journey could possibly be. 


\section{CHAPTER VI \\ Flying Fish and Turtles}

$F_{\text {ROM NOW ON the reader will hear again and again }}$ of Allison Armour, a friend of many years' standing. Shortly after the First World War, he converted a small Swedish tramp steamer into the most luxurious floating laboratory in the world, and renamed her the Utowana. $\mathrm{He}$ did this primarily to aid his friend David Fairchild in transporting useful plants for introduction into the United States. Happily on several occasions he asked me and my family to go along and to add zoological collecting to the botanical work.

On one of these voyages I had a unique opportunity of observing flying fish. The Utowana was anchored off Mathewstown on Watlings Island, or San Salvador. Allison and I entered one of the ship's launches to go to a cay off the north end of the island where iguana lizards were said to be found. Where the yacht lay at anchor it was perfectly calm, but when we got clear of the point an enormous oily swell was rolling. We were running along with the swell abeam. Now we would be running along the crest of one of the great rollers and the next moment be in the trough. On these occasions we could look right into the great clear swells as they loomed up on each side of the launch.

All of a sudden the water broke and a couple of flying fish, frightened by some larger fish which I never saw, 


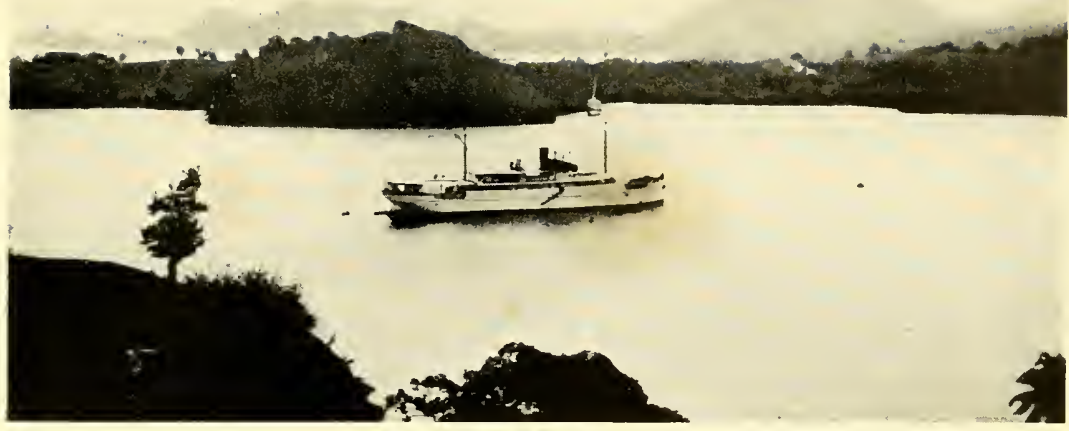

Photo by Allison Armour

Utowand in Port Castries Harbor, St. Lucia
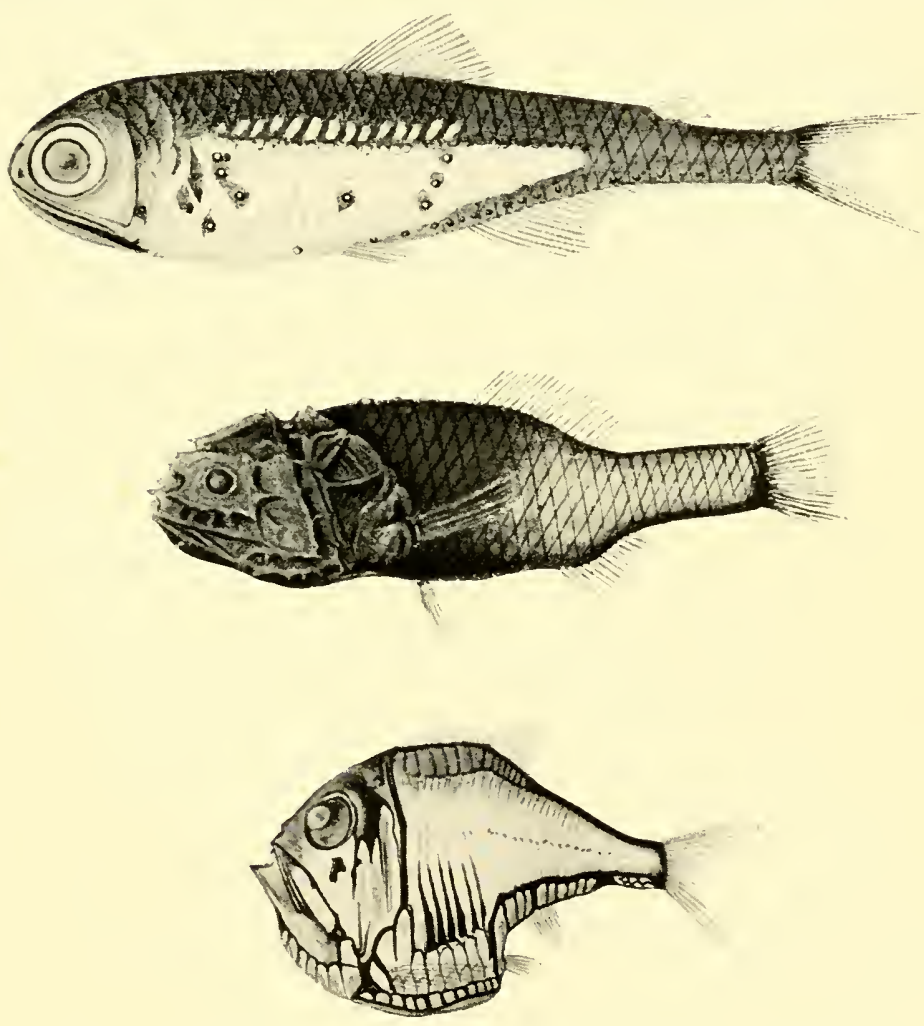

Three deep-sea fish drawn by Alexander Agassiz 

flew directly across the launch, right before my eyes. Had I known the fish were coming, I could have caught them with a net or touched them with my outstretched hand. I had thus an unrivaled opportunity to kill once and for all the notion that they move their fins in flying. As is well known, this has been a moot point amongst naturalists, though it never should have been. No flight muscles are revealed on dissection of the fish, yet the fact that their fins do move has been insisted on time and time again. I have watched them on so many hundreds of occasions that I believe the observational error is to be explained in this wise: The wings are very thin and delicate and sometimes when flying fish are chased out of water and there is a good sharp breeze blowing, their wings appear to move, being caused to flutter by the angle at which the fish takes the wind. Flying fish fly most freely in fairly calm weather. I imagine that then they are swimming nearer to the surface. In a heavy storm I have never seen fish fly at all. Once I saw one caught in the air by a canary-yellow dolphin fish, which rose at least three feet out of water to snap up its prey.

It was in the Bahamas on another occasion that I saw an interesting sight. A giant loggerhead turtle, floating lazily on the surface, would swim up to and gulp down Portuguese men-of-war, or Physalias, which were floating about abundantly. The old turtle would ease up to the Physalia, close his eyes, and make a snap for it. I suspect that the hard, horny jaws and the tough skin were impervious to the painful stinging caused by the nettle cells of the Siphonophore's tentacles, but that probably the tender skin 
about its eyes offered no such protection and the blind gulps were to protect these areas.

The loggerhead, not being fit to eat, is still an abundant sea turtle all through the West Indian area. Green turtles have grown scarce because they have been hunted so constantly. They are brought to Limon in Costa Rica for shipment to the aldermen's feasts in London, being carried in individual tanks on the forward deck of the Fruit liners crossing the ocean. Kindhearted persons often are hurt by seeing the turtles kept lying on their backs. They little realize that if they were kept lying plastron down, which would be their natural position, they would soon die, the lower shell being weakly constructed and incapable of long supporting the weight of the turtles. I am sure this would not apply to small individuals, but I have been informed by many turtlers that it is dangerous to leave big, heavy turtles on their stomachs for very long.

Once, climbing up a high cliff overlooking clear, still water along the shore of New Providence Island, I frightened two turtles which had been grazing on seaweeds on the bottom quite close to shore. One was a green turtle and one a so-called Ridley, another species altogether. Both turtles raced away, the green turtle quite deliberately and the Ridley with an astounding burst of speed. My friend Dr. Archie F. Carr, Jr., of the University of Florida, who is an authority on turtles, has noticed this same fact on a number of occasions, and he tells me that, unlike all other sea turtles, the Ridley when brought ashore snaps about in such a blind rage that it tires itself out and would probably fidget and worry itself to death in a short time if allowed to do so. Sea turtles are fascinating critters 


\section{Flying Fish and Turtles}

and it is a pity that the demand for tortoise shell has brought one magnificent animal as close to extinction as the delicacy of its flesh has brought another.

Georgetown, Grand Cayman, which we visited on several occasions, is the center of the green-turtle industry. The Cayman Islanders are expert boatbuilders, and their fast-sailing schooners comb the cays of British Honduras and Nicaragua, turtling for soup meat. I have been told that most of the turtles are caught with a bullen, an iron hoop to which is attached a deep net. The schooner anchors. The small boats set out with one man to scull in the stern and another in the bow peering down into the clear water with a bucket having a glass bottom, called a water glass. When a green turtle is spied resting on the bottom the bullen is let down as close to it as possible, a rope being attached to the apex of the net. The instant the iron ring strikes bottom the turtle gives a surprised leap upward, pushes its four fins out through the coarse mesh of the net and, thus entangled, may be drawn to the surface. Turtles, of course, are also "pegged" with a harpoon having a little head which comes loose, with a line attached. But this is less satisfactory in that turtles may be badly injured, hence less likely to survive the long voyage to market.

They seem pitiful objects, with their great fins folded across their breasts made fast with a bit of binder twine rove through holes cut in their flippers. But I suspect that this really doesn't hurt the turtle very much, as they seem to pay little attention to much more shocking injuries. Individuals are often seen that have lost a large part of one or more flippers, so that in some cases they can swim only 
with difficulty. This is commonly supposed to be the work of sharks. But I think it is much more likely that the injuries are caused by fighting with other turtles. There is always great excitement when the turtle schooners come to Key West. One Cayman vessel will often carry a hundred or more turtles stacked up in its hold. They probably average 200 pounds apiece and the cargo is a very valuable one.

I landed one morning from the Utowana on the Island of Saona, off the coast of Haiti. It is a rather flat, uninteresting little island and I was not prepared for what I found. I knew that there was a high degree of endemicity on all these islands around the Haitian coast. I knew, also, that Saona had never been visited by anyone in search of reptiles, so I walked around the confines of a small open garden patch, knowing that this was the sort of terrain where one might expect to find Ameiva lizards. Lizards of this genus have a way of splitting up, so novelties may be expected.

I hunted a long time before I heard a noise in the dead leaves. Ameiva lizards are anteaters and scratch with their paws among the leaves, throwing them about in their search for the insects which may be below them. I approached the sound as stealthily as possible and could scarcely believe my eyes when I saw a perfectly typical Ameiva, and by the same token one utterly unlike any which I had ever seen. I have collected countless numbers of lizards of this genus. I shot this lizard on April 8, 1934. It was lilac gray on the back, washed with fawn color on the head and turning to pale blue on the tail. A black band, beginning 
with the eyes, ran along the side of the body and the tail, which was azure blue beneath, while the undersurfaces of the body were glaucous blue, suffused anteriorly with cream color. The sides of the head were buff yellow. All in all, it was one of the most beautiful and strikingly colored reptiles which I have ever seen.

I sent the specimen to Miss Cochran of the National Museum in Washington, who was writing a herpetology of the Island of Hispaniola, although I fairly itched to describe it myself. I realized it was new the second I saw it, as I have said before, and I asked her if she would name it for my wife. She not only named this species Ameiva rosamondae, but without my knowing it she named the Ameiva from La Gonave Island for me.

The Haitian peasants are so poor that they will struggle hard to catch lizards, snakes, frogs, and toads - which they do not really like to do - if they can sell them for five cents each, and I mean five cents of a Haitian gourde, which is only worth fifteen cents to start with. We often had as many as a hundred people collecting for us. In this way, on the islands that were populated of course, it was possible to secure in a few days as much material as a single person could have gotten during a long stay, so that while we stopped at innumerable different localities during these voyages on the Utowana and never had very much time at one place, all around Haiti and in the Bahamas we got big collections. You can do this in Jamaica, but not in Cuba.

We stopped on one occasion at Isle Tortue. I went ashore in the morning and passed word around that we would be back in the latter part of the afternoon prepared to purchase what might be forthcoming, explaining what 
we wanted. I had a sack of Haitian five-cent pieces on board the yacht. We found that we got much better results from our collectors if we ourselves did not stay where they could watch us. It was so much more fun to stand and stare at strangers than it was to do anything else that the temptation was quite overwhelming. But if we went ashore in the morning and spread the news of what we were prepared to do, then disappeared on board and hauled up the gangway, by the middle of the afternoon we could go ashore and be overwhelmed by a rabble of men and women, boys and girls, with snakes and lizards dangling at the ends of dozens of little lassoes which they fashioned cunningly from shredded palm leaves.

On one occasion a poor old man came up to us with a gourd full of fat white grubs. These he had dug out of a rotten palm trunk. I recognized them at once as the larvae of a big weevil which lives in decayed palm wood. Of course he brought them feeling sure we would buy so succulent a dainty, for the Haitians are extremely fond of these grubs fried. Rosamond was utterly disgusted by their very appearance and I was not allowed to take them on board and eat them, which I should have greatly enjoyed doing. I have no right to complain, however, for the family did not relish the intimacy with a wide variety of reptiles which they patiently endured. 


\section{The Sea and the Cave}

Some of the most delightful incidents of my life have happened at sea. I recall a still, calm morning off the west coast of Nicaragua. There was literally not a breath of air to stir the surface of the water. And far and wide, scattered to the horizon, were the images of white birds. They appeared miraged up so that they looked about twice as big as gulls should be. The answer was soon to see, for each gull was standing on the back of a basking sea turtle floating or swimming slowly upon the surface of the ocean. The effect was extraordinarily lovely, and I have always recalled it with the greatest pleasure.

A few days later, with the same good weather, we passed through great swarms of coral-red crabs swimming busily along the surface of the ocean, as if all bound upon an important errand.

I often think of the emotion and excitement, which I suppose has occurred for years and will occur until time ends, when a naturalist sees an albatross for the first time. On the wing - and you mighty seldom see them swimming on the surface of the sea - they look entirely unlike any other bird. Their wings are so long and so sharply pointed that you hardly see the body at all; you simply see this great, straight, unbending pair of wings. To see them at their best the sea should be stormy.

They don't sail the billows as pelicans do, rising and 
gliding with their wings parallel with the surface of the water, but they cut and pivot and jibe about as if they were standing on end more than half the time. Indeed, it looks as if they stuck the tip of one wing in the water and used this as a fulcrum as they pivot to swing past the crest of a wave. On the voyage to South Africa you meet them shortly after leaving Saint Helena, and for a day or so before reaching Cape Town you may see great numbers. They are perhaps even more abundant off Southern Chile, and if by chance you should pass near the floating carcass of a whale you will see them in swarms, like herring gulls in the harbor of Key West after a bad cold spell in the north.

Porpoises are always diverting and, of course, are familiar to every traveler at sea. But on three occasions we were extraordinarily thrilled by seeing gigantic schools of porpoises that behaved in a quite extraordinary manner. More than one species nilust have been involved, for once we saw what I am about to describe off the west coast of Costa Rica, once near Amboina in the Moluccas, and the third time nearing the Cape of Good Hope.

On each occasion the sea was calm and still. There may have been an occasional porpoise rolling lazily, as one is accustomed to observe them, but on each of these three mornings the sea became suddenly alive with porpoises thousands upon thousands of them, rolling and jumping high in the air, jumping over one another, past one another, boiling and plunging. There seemed no question but that they were playing, as I saw no evidence that they were driving fish before them. After carrying on in this manner for perhaps half or three quarters of an hour, as if 
at a signal the whole school swam off. As they disappeared, the animals rolled gently in order to breathe, but they hardly cut the surface of the water.

Another morning I like to think about was when the Utowana lay anchored off the mouth of the Yaqui River at the head of the Gulf of Samaná in the Dominican Republic. The muddy water of the river pushed out into the clear turquoise-blue water of the Gulf, with the line of division sharply marked since the dirty fresh water did not readily mix with the clean salt water of the ocean. An extraordinary procession patrolled the boundary line. Giant rays went flying through the water, their great wings flapping, each one as big as the top of a grand piano, and some larger. They were so near the surface that their great fins came up into the air as they flapped their way along, and every once in a while one would leap high and land with a resounding whack. This kept on pretty much all day.

One would naturally suppose that they were feeding, and yet these great fish are normally bottom feeders. With their protrudable lips they pick up clams or conchs on the bottom and crush them with their curiously modified, flat, platelike teeth. In the Oceanarium at Marineland, in Florida, they had a ray which picked hard clams off the bottom, and I could hear them crack. The crunch which ground them up was so powerful that the noise carried through the plate glass.

It is a pity that the Gulf of Samana is not readily accessible to visitors. It is one of the loveliest spots in the whole world. On the north side the mountains rise, covered with a fine green forest. Down the mountain roads the peasants 
come riding their well-trained bulls laden with heavy packs to go to market in little towns like Santa Barbara de Samaná - quaint little Old World towns that date back almost to the time of Columbus.

The other side of the Gulf offers a complete contrast, for long ago this must have been a flat limestone plain which has been cut and eroded away to form a labyrinth of little rocky islands, each one deeply undercut by the surf, the rocks dripping with orchids and begonias and great elephant-eared aroids, and beset with tall slender palms. Their little stalks are strong as a long iron bar would be, for these palms are old and have stood against countless hurricanes. There are many caves in these little islands, in some of which fishermen live in primitive simplicity - a fairyland, if ever there was one.

In 1908 I went as a delegate to the first Pan American Scientific Congress, held at Santiago, in Chile. Because it was more convenient in those days, we went to Europe and sailed from Lisbon to Brazil. Then we visited Montevideo and Buenos Aires. A theft of jewelry from my wife, which required us to return to Mendoza to testify, prevented us from crossing the Andes with the American delegation to the Congress. I had not expected that this South American journey would afford many zoological high lights, for it had a political background, but this delay provided a few which I should like to record.

Everyone deplored the fact that we could not travel straight through from Buenos Aires to Santiago. The railroad, however, was not yet completed. We went by night from Buenos Aires to Mendoza on the very comfortable 


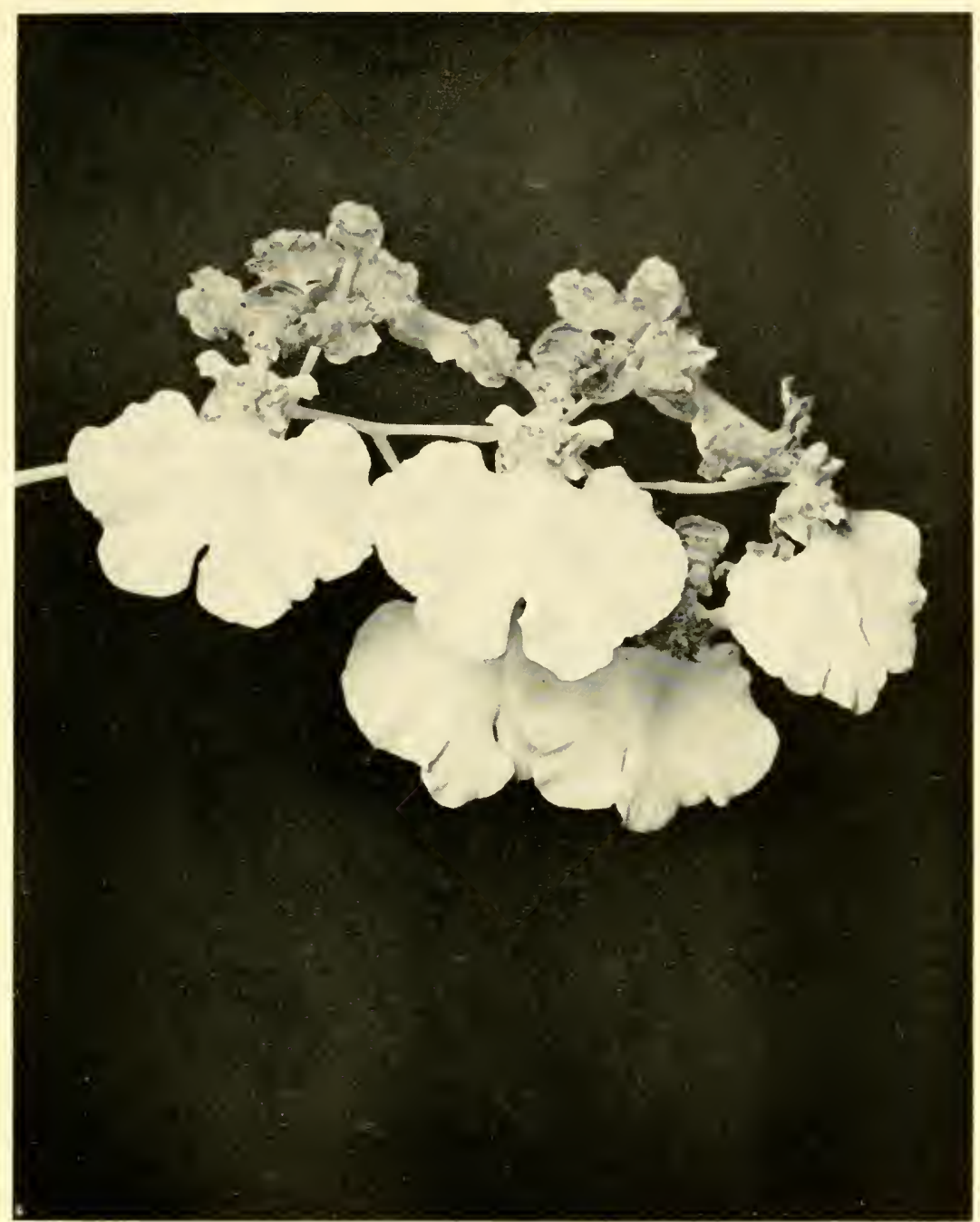

Photo by Frank White of the American Orchid Soctety

Dancing Girl Orchids recall the market at San Salvador 

broad-gauge sleeper, spent a day there, and the following morning took the narrow-gauge Trans-Andean line. But everything turned out well. The officials of the railroad allowed us to ride on the cowcatcher, getting on where the real rise begins, at Punta de Las Vacas - where I found two good toads in a small water tank which supplied the locomotive - and from there riding to the end of the line on the Argentine side. The railroad wove about, rising ever higher and higher. To right and to left we had a splendid panorama of high mountains. The terminus was at Puente del Inca, where a simple but clean and comfortable little bath house had been built in connection with some hot springs that gushed out near the natural bridge which gives the place its name. We stayed there several days. Finding excellent sure-footed mules available, we took the opportunity to see some of the most superb mountain scenery in the world and to catch glimpses of the bird life of the highest elevations of this southeastern portion of the Andes.

Fitzgerald began his classic ascent of Mount Aconcagua from the Horcones Valley whence the ascent is steep and long but fairly direct. In this valley high up on the hip of the highest mountain in either North or South America there lies a charming little lake. It is called the Laguna del Inca, although in all probability no Inca ever laid eyes on it. The view of this little azure gem of a pond sparkling in the brilliant sunlight, with the majestic snowclad slopes of the great mountain overshadowing it, was one of the most ineffably lovely views I have ever seen.

I don't know exactly what the altitude of the pond is, but I suspect it to be about 14,000 feet. I rode up to its 
shores with the keenest anticipation. On this day I took the precaution of rolling a stone over on the reins of my mule - because the day before, high up on a mountain to the south of Puente del Inca, my mule had walked away from me down a rocky slope so precipitous that I expected him to go head over heels at any moment. Luckily our guide appeared on the scene and spurred his own magnificent animal after my beast lickity gallop down this same slope. He caught my mule and brought it back to me with a smile as if he had done nothing, but I had learned my lesson.

On this occasion I was praying under my breath that I might see a tiny brown lizard about five inches long and quite nondescript as to form and color. I had happened to read Fitzgerald's account of climbing Mount Aconcagua not long before we started for South America and I remembered that in the appendix of the book Dr. G. A. Boulenger of the British Museum had described a lizard, which he called Liolaemus fitzgeraldi, and that it came from within a few hundred yards of where I stood. In the winking of an eye I spotted one resting on a stone in the sun, but catching him was quite another matter. I am big and clumsy - and clumsier still when I am at I 4,00o feet above sea level. My puffs and grunts as I lunged in vain amused Rosamond and Archie Coolidge hugely. In time patience had its reward and I ended up with seven or eight of the little devils, which I suspect no one but Fitzgerald and I had ever caught. This locality may not be the highest spot in the world where lizards live but it certainly is one of them.

While this chase was going on, the great condors kept sweeping by in majestic flight. No one of the carrion-eating birds is so clean-looking and attractive, except possibly the 
King vulture of tropical America. There is nothing of the unpleasant appearance when you see them near by that marks our turkey buzzards or more particularly the vultures of the Old World, many of which are inexpressibly loathsome. But it was not the condors which gave us the greatest thrill but rather the giant hummers. Scientists know this bird as Patagona gigas; it is the largest member of that most numerous family of birds, the Trochilidae. Patagona does not share the beauty of form and color of most of the members of this group. It is purely remarkable for its size - considering that it is a hummingbird - for it is nearly as big as a robin. Of a dull, rusty gray-brown color, it sits stupidly perched on sticks and stones, is quite tame, and is awkward in shape. It is cylindrical in appearance as its rests with its long wings folded. It may not sound like a very exciting bird to behold, but it gave me an everlasting thrill.

While our colleagues on the trip had been transported from railhead to railhead in horse-drawn coaches, we traveled on horseback, reaching the Chilean side on a day when there was no train. By great good fortune we found that some of the railway engineers were going down to Santa Rosa in a gravity car and they took us "down the hill" with them.

We all sat bunched up on an open platform with nothing to hang onto - and how we jerked as we took the curves! From Juncal down to Santa Rosa is a vertical drop of about 10,00o feet: we took it at a rush through tunnels and over trestles with nothing but a hand brake between us and the blue. There was a burro on the tracks near the end of a long tunnel, but we shouted him out of the way just in time. The engineers had broken all rules in taking 
us with them, and when at last we were safely down at sea level, Rosamond and I repaid them in champagne.

The festivities in connection with the Congress at Santiago were cordial and extremely well organized, but of more interest to us was the visit to Valdivia and Corral, in the south of Chile. Here we succeeded in finding not only some new fresh-water Crustacea but some extremely interesting frogs and toads.

One day when we had run out of containers I purloined Rosamond's sponge bag and filled it with frogs, hung it up in our room, and went out to buy bottles. I hadn't tied it up very well and when I got back the floor, furniture, and walls were liberally besprinkled with tree frogs hopping about and climbing with their little sucking toes over everything, including the windowpanes. As usual I was penitent and unpopular, but this didn't catch the frogs.

Don Carlos Reed helped me secure our grand series of Rhinoderma. This strange little frog has a unique habit, inasmuch as the male picks up the eggs as the female lays them and packs them into the singing pouch in his throat. Here in due time they develop to the point where, when he opens his mouth, the little froglets leap forth into freedom. The tadpole stage is passed in the male parent's throat pouch. This frog is confined to southern Chile. Around Valdivia and Corral, we had some very fruitful collecting, finding not only lizards and amphibians but some extremely interesting fresh-water Crustacea as well, including a new fresh-water crayfish recorded from the most southerly station in America.

On our voyage north when we landed at Coquimbo we were invited to drink a glass of champagne with the city 
fathers of the old town of La Serena some miles inland. And while this is one of the driest and most deserty parts of the world, I spotted a little marsh not far from the inland town. As soon as I sipped down the warm sweet champagne and could make a polite getaway, I skipped out and found that the marsh was swarming with frogs. This was all to the good, and I caught a number of them.

A few days later at Pisagua a penguin which I had seen from a distance came swimming right up to our ship just after we dropped anchor. Here the water was crystal clear and the bird, nipping its head from side to side as it peered about, came right up to the side of the ship. Then it dove with a sudden plunge and passed straight under the keel, giving me time to run across the deck to see it come up on the other side of the vessel. Since boyhood I had longed to see a penguin at large. To me the sight was as memorable as that glimpse of the giant dolphin which, to rid himself of a sucking fish, rubbed it off against the side of our vessel in the harbor of Port Said and then, making a quick turn over backwards, snapped up the fish and ate it.

The great herds of sea lions along this part of the South American coast were also sources of amusement and interest. In those days ships anchored far off shore and one reached the town in longboats which were laboriously rowed shoreward. The sea lions leaping in the air and calling out with their characteristic raucous cries were jolly companions on every trip to land.

I recall one rather gruesome event, when all the lizards around Areca seemed to be concentrated near a graveyard which had been, shall I say, seriously disturbed by a recent earthquake. It was hard even for a rabid enthusiast to fol- 
low a lizard which had run into the boot on the foot of a corpse, even though the corpse was pretty well dried up and shriveled. This drying happens quickly in this excessively dry climate.

Some friends of ours, the Arthur Jacksons, had lived for many years in La Paz in Bolivia. Arthur had charge of the interests of the Boston and Bolivia Rubber Company. Through him I met a Mr. Dunleavy who mined placer gold at the junction of the Kaka and Beni rivers, far down in the Amazonian forest. He gave me a lizard which he had picked up near his gold diggings and one which was not only new but which was one of the most beautiful that I have ever seen. It was ringed with sharply defined bands of black and ivory white and the whole under surface of the beast was suffused with a rich rosy hue. I named it Diploglossus resplendens and it has never been found again from that day to this. By a curious coincidence my cousin Gordon Barbour now owns and operates this same gold field, flying in and out from La Paz with his own airplane instead of riding over the bitterly cold Andean passes via Sorata for days and days on muleback, formerly the only way to enter the region.

The Jacksons knew the railroad people well, and were aware of their hospitality to strangers. They arranged for a day at the ruins of Tiaguanaco. We had a car hitched to the early morning train from $\mathrm{La}$ Paz to Guaqui on Lake Titicaca. This was dropped off at a siding near the ruins, which are directly beside the railroad track. We lunched in the car and returned from time to time to deposit our plunder until the evening train picked us up and brought us back to La Paz. I had an unforgettable experience here 
chasing lizards in a snow flurry albeit at a mighty slow pace, for the ruins stand some 13,000 feet above sea level. We found, however, that these lizards tended to run in under one of the loose stones of masonry which had fallen from the ruins, scattered everywhere over the high plain. By turning over the smaller stones it was possible to catch the lizard with a quick slap of the hand. I caught an interesting new species of the same genus Liolaemus which I had first taken at the Honcones Valley and of which by this time, during our various collectings over western South America, I must have picked up a dozen different species.

Traveling on the west coast of South America was a leisurely process forty years ago compared to what it is today. We made three bites of the cherry, going first from Valparaiso to Mollendo in an old-fashioned Chilean vessel, the Limari. Then later we moved up the coast from Mollendo to Callao and then from Callao to Panama, the three laps consuming forty days. This of course gave a wonderful opportunity to see this most entrancing coast line, since we stopped, I think, at least once every day and cruised along slowly close to the shore. The abundant bird life and its relation to the Humboldt current have been described very adequately, but the beauty of the scenery has never been exaggerated. I include the birds as part of the scenery, the great long rippling lines of boobies which would cross right over the ship, and the unbelievable number of cormorants and pelicans.

Once on this trip we occasioned considerable consternation. We put up at the Hotel Ratti in Juliaca - concerning which I remember only that the pillowcases stuck to the pillows! But we had acquired a rare Armadillo at Viacha 
in Bolivia, which we had not been able to preserve as a specimen and which was not very efficiently caged. It escaped in our room in the hotel, rushed pell-mell out to the balcony directly over the front door, and plunged overboard - landing in the midst of one of those conclaves of city fathers who always appear to be discussing something very important. My unpopularity for a time was unbounded.

It was a bitter disappointment that limitations of time, steamboat accommodations available, and other circumstances prevented our going to Cuzco. Perhaps we were foolish not to have thrown up everything else and made the trip, but the railroad had been laid recently and had a way of sinking down along the stretches of boggy land. We were simply cowardly about it and missed a visit which I have regretted a thousand times. Of course Arequipa was charming, the mountains glorious, the vegetation exciting to a naturalist, and the traveling crescentic sand dunes called Medanos seen about halfway to Mollendo extraordinarily arresting.

One little event occurred at Lima which is perhaps worth recording. Our room was on that side of the old Hotel Maury directly across from one of the towers of the great cathedral. One evening I said to Rosamond, "Those are awfully funny-looking bats going in and out of that hole in the tower across the street." We stood there, leaning on the railing of the little balcony of our room, watching them, when all of a sudden, by the greatest good fortune, one of the bats detached itself from its companions and flew directly into our room. We slammed the doors and got it. It proved to be Amorphochilus schnabeli, a bat which 


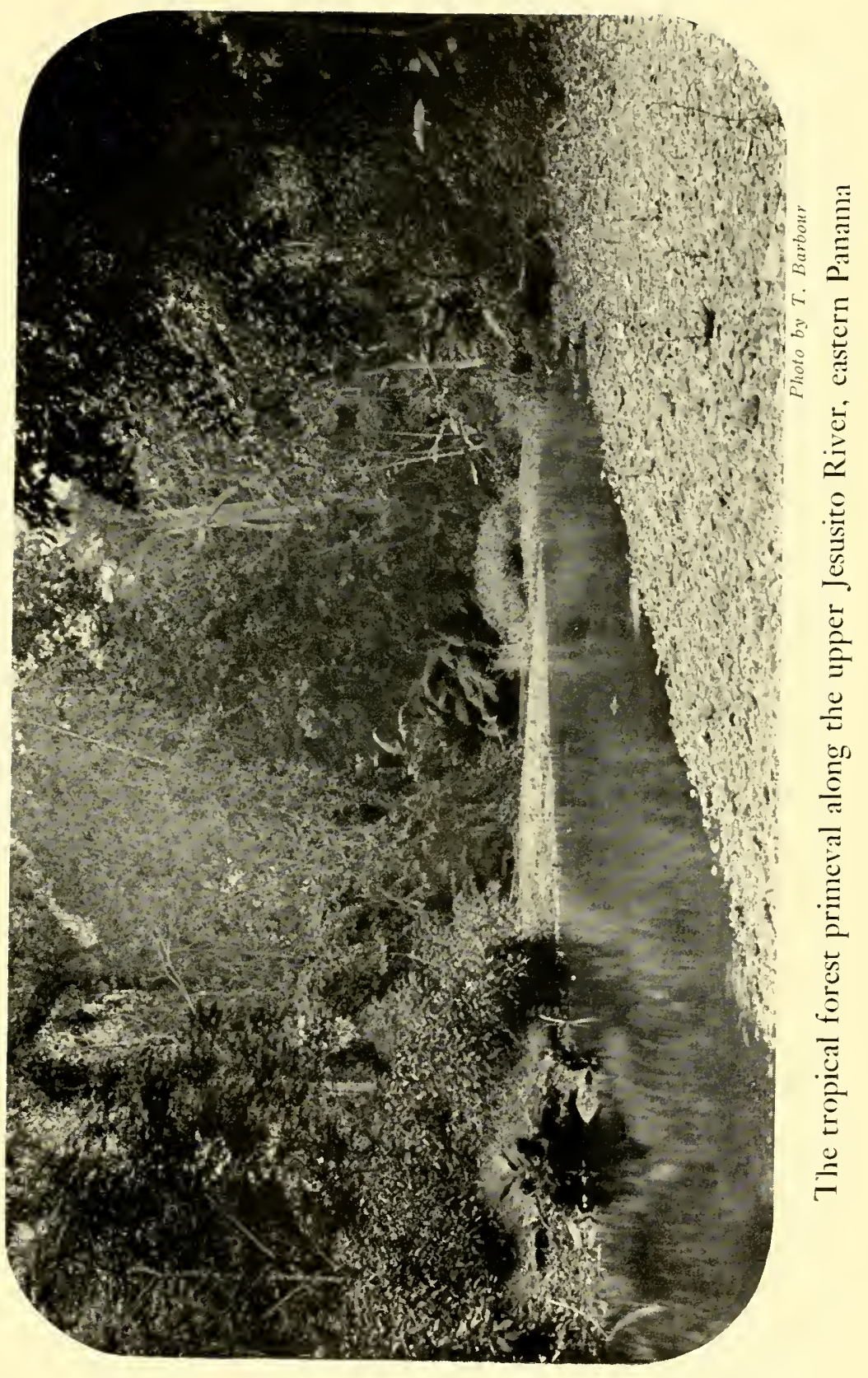



had been described many many years before by Peters from a specimen caught up at Tumbez near the Ecuadorian frontier and which had never been found again until we caught our one tiny windfall.

We returned from the Congress with General Gorgas and his family: they were bound for Panama but we were going only as far as southern Peru. We were together for two weeks on the old Chilean ship, the Limari. We hadn't been on board long when Rosamond found that one of the two bathroom doors was always locked. This was extremely inconvenient, and she spent some time spying out the cause. After some conniving she got a look into the room and found that the bathtub was full of water in which were swimming a number of goldfish.

Bishop Pierola, the shepherd of the enormous Indian diocese of Huánuco in the Andes of Peru, had been to make his ad limina visit to the Sovereign Pontiff in Rome. $\mathrm{He}$ had acquired the goldfish, and his chaplain, being charged with their safekeeping, had simply bribed the bath steward and taken up one of the two bathrooms in the ship for the Bishop's goldfish. They stayed there, too.

Later on General Gorgas, who did not speak much Spanish, came to me and asked me to tell the mozo in charge of the one remaining bathroom that he wanted clean water. The fresh-water supply was locked up and we couldn't run our own baths as the supply was limited; hence the necessity of calling the mozo. (Gorgas had not learned Spanish on purpose, because, as he said, he had so many difficult duties and such unpleasant ones, in connection with the sanitation of Panama, the burning of buildings and worse, that he did not wish to be able to understand 
the frightful curses which were heaped upon him.) I spoke a little Spanish and approached the mozo, who answered, "Tell the General that the bath water is sweet and nice. Nobody has been in it but those two young North American ladies, and they use such sweet-smelling soap." The General, however, insisted that he preferred clean water, and finally he got it.

When we reached Panama the Gorgas family was so kind to us that we felt we had reached home. The General ordered a place fixed up for me to work in the old Board of Health Laboratory. And one event of our stay was sufficiently exciting to record here. I had one of the first-class, all-wool, yard-wide frights of my entire life. Through Dr. Gorgas I met Mr. Le Prince, one of his most famous mosquito sleuths. Le Prince was a keen sportsman. One evening he suggested that we go deer hunting across the canal out in the country, which I suppose now would be designated as inland from La Venta Beach. He had an extra headlight for me and we borrowed an extra gun. Tracks in the mud showed that there were plenty of deer, but for some reason we did not succeed in shining a single pair of eyes. We walked and walked. Finally, far ahead down an old road, in the scrubby woods, I saw a pair of blazing orbs. I knew mighty well they were not the eyes of a deer but what they were I could not guess. I strongly suspected a jaguar.

I stood looking at them, when all of a sudden it became obvious that they were approaching me very rapidly indeed, rapidly and soundlessly. In less time than it takes to tell it, they rushed at my light and swept by over my shoulder, my face being fanned with the air moved by the wings 
of a big owl-Rhinoptynx, no doubt. The whole occurrence happened in such a short time that I had never thought of shooting. I can't say that fear bathed me in sweat, because I had been as completely wet with sweat as any human being could be from the moment our hunt began. But my knees were certainly rattling and I was as jittery as I have ever been, which is saying a good deal. We walked back, shining no more eyes excepting those of the enormous bird-eating spiders which are always aprowl at that late hour, and whose eyes looked like fiery emeralds. When we reached the spot where we had left our borrowed ambulance, we dealt out a stiff swig of quinine and clopclopped back behind our army mules to our quarters in Ancon.

I can hardly credit my memory when I think of a trip like this or the visit we made, also in an army ambulance, to the ruins of old Panama. As I remember it, Aileen Gorgas and I rode horseback; all the rest rode behind the mules. Can there be any spot in the entire world today which offers a more complete contrast than the Panama Canal Zones of 1908 and 1943? It is a safer place to live in today, as far as health conditions go, but, it was a far more amusing and delightful spot at the time of which I write.

In 1910, with a number of others, I represented the Association of American Universities at the reopening of the ancient University of Mexico in Mexico City. This coincided with General Porfirio Díaz's last inauguration as President. We were sumptuously cared for by the Mexican government. We American delegates had a house at our disposal, and motorcars at beck and call. The great 
banquet, given to all the assembled dignitaries, was one of the most extraordinary occasions of its kind that I have ever attended. The tables were set on the floor of an enormous cave near the pyramids at San Juan Teotihuacán, and not only were the silver and china-brought from the palace in Mexico - decorative in the extreme, but the entire floor of the cave was carpeted several inches deep with tens of thousands of gardenia blossoms. Of course these can be bought for a song in the highlands of Mexico, but the effect was amazing and the scent almost overpowering.

The inaugural festivities in Mexico ended with a procession in which General Díaz walked with the delegates, who wore academic costumes and made quite a show of color. The next day there was a military parade, and after seeing the ten thousand Rurales prance by on their beautiful horses and with their extraordinarily striking costumes one little dreamed that in but a short time Díaz would be leaving Mexico for Spain as a refugee.

Before returning north Professor Tozzer, Clarence Hay, Rosamond, and I visited the ruins of Xochicalco near the boundary of the states of Morelos and Guerrero. The things that stick out in my memory above all else are the buildings which the Indians at the village of Temisco in Morelos made to store their corn; the rock iguanas, big black lizards which decorated every stone wall; the dreary ride, and the uncomfortable night at the ruins. But topping all else, I remember the visit to a near-by cave in which, by the greatest good fortune, I managed to secure with my hat some specimens of a rare bat, Choeronycteris.

I became so interested in caves at one time that I suggested to William Morton Wheeler that we start a Society 
of Speleologists. He was enthusiastic, but we finally concluded that there was not enough of an interested group to make it worth trying.

I have had grand experiences exploring caves. In the spring of I9I I, Dr. Carlos de la Torre, of the University of Havana, found among the notes which he had inherited from his old teacher, Felipe Poey - a very great naturalist indeed, and one whose contributions to the natural history of Cuba are well known - the statement that there was a cave near Cojimar which had red shrimps in it. Don Carlos and I took a guardaño - one of those little canopytopped rowboats that ferry one about the harbor of $\mathrm{Ha}$ vana - and crossed over to Morro Castle.

On the little beach just by the battery of the Twelve Apostles there lived an old fisherman named Lesmes. $\mathrm{He}$ had been a collector for Poey and was knowledgeable in all sorts of ways. We questioned him and he said, "Yes, there is a cave back in the scrub, several miles from here, which has shrimp in it which look as though they had been boiled." The upshot was we started out to find the cave. We wandered through the hot, dusty growth of beach-grape trees for a couple of miles and came to what had obviously once been a small cave, the roof of which had fallen in.

Sure enough, swimming about in the crystal-clear water, which here stood quite near the surface of the ground, were to be seen fairy shrimps of the most heavenly crimson hue, slender and most delicately formed, with white tips to their appendages, as if they had stepped about delicately in white ink. We collected a number of these and in due season sent them to Miss Mary Rathbun, the famous carcinologist of the Smithsonian Institution. She wrote me 
that these shrimps were unique, the only members of the family Hippolytidae that had taken to cave life. The members of this family inhabit the deep sea and a vast number of deep-sea Crustacea are red. All other cave shrimps which I know of, like most other cavicolous animals, are pure white. She named this shrimp Barbouria poeyi, which pleased me very much.

I am going to digress for a moment at this point and say something about zoological names. There is always a generic name written with a capital, and a specific name, and sometimes also a subspecific, always written in lower case. The manufacturing or thinking up of generic names is not always easy, since you have to think of names which have not been used before, and the number of names that have been used mounts into many thousands. Therefore a person with a name which works up reasonably euphoniously is a good deal of a godsend to describers; so we have Barbourella, Barbourina, Barbouricthys, Barbourophis, Barbourula, and I think several other such combinations, all slipping off the tongue with reasonable comfort.

But consider the way Dybowski, for instance, has transgressed, and some of the names which he has proposed for free-swimming Crustacea in Lake Baikal: Leucophtalmoecbinogammarus leucopbtbalmus, Stenophtbalmoecbinogamtmarus stenopbtbalmus, Cornutokytodermogammarus cornutus, and, best of all, Brachyuropushkydermatogammarus grewinglii mememotus. I call this dirty ball. Thank God these have all been outlawed by unanimous consent of one of the International Zoological Congresses.

Not long ago I had occasion to make some rather nasty 
remarks about some perfectly good friends of mine who perpetrated such a name as Photichthys nonsuchae. Pretty terrible, for "nonsuch" can be translated into decent Latin. But my friends were not classicists; otherwise, naming a fish seen and not caught - in itself a mortal sin - Batbysphera intacta would not have been used and naïvely interpreted as "the untouchable bathysphere fish."

But to get back to our caves. Cuba, like many other limestone countries, abounds in caves and grottoes of all sorts, and I have explored any number of them. Three, however, stand out particularly.

There is a little range of limestone hills a couple of miles east of the Harvard Botanical Garden at Soledad in a pasture called El Portero de los Vilches. Here there is a shallow cave in the face of a cliff which was used years ago as a bivouac or lookout by both the Spaniards and the Cuban rebels - whichever happened to be in control of the area. This cave is known as La Cueva de la Macha. It is open to the light, a great domed chamber, the front of which fell off and crashed down the hill years ago. Windblown dust has been carried in in the course of the ages and the floor of the cave has been covered with a foot or two of dust.

We visited the cave often, as it was within walking distance of the Soledad plantation. Scattered over the surface of the dust in the cave were the remains of desiccated owl castings. These contained the undigested bones of introduced European mice and rats. It occurred to us that if we got down deeper in the dust we might find the remains of animals which existed before the coming of the Span- 
iards. This turned out to be the case, and we dug, sifted, and screened on many occasions. We found the bones of a number of extinct animals and, to top it all, the only absolutely perfect skull of the extinct rodent Boromys torrei which has ever been found anywhere.

A visit to a second Cuban cave also turned out to be extremely valuable. My young friend Victor Rodriguez and I set forth from Havana to Matanzas and there changed cars to a little branch railroad which ran down into the Black Belt of Cuba, the southern part of Matanzas Province. We got off the train at Alacranes, not far from the larger village of Unión de Reyes, and inquired for La Cueva del M.

We found it was in an area mostly planted out in cane and we chartered an old, broken-down victoria, drove as far as the road would allow, and then walked on. The cave was as easy to explore as any I have ever seen. We entered through a great open archway and descended by a gradual inclined slope until finally we came to a great body of water which completely covered the floor of the cave. There was no going beyond this point. We could not have done so even if we had had a boat, because the roof of the cave dropped down, so that there was only a very short space between the roof of the cave and the surface of the water. This subterranean lake simply swarmed with life. We got a wonderful collection of blind fishes, finding both of the known species living there side by side with blind shrimps.

When we reached the mouth of the cave on our return we were surrounded by rural guards and promptly arrested. But thanks to Dr. de la Torre, we had credentials 
from the Secretary of the Interior of Cuba and we were royally treated when the Rurales discovered our identity. They had thought that we entered the cave for the purpose of purloining treasure "known to be buried there." But they were content to let us have our peculiar "treasure."

A totally different sort of cave was that which a guajiro living near Madruga advised us to visit. This was one of those deep, dark caves, whose presence is made evident by the fact that the roof of one of the underground chambers has fallen in. In this cave trees had grown up and it was possible to clamber down to the floor through the branches of a tall, scraggly jagïey. Once down, we found that the cave spread out more or less in all directions and here one needed a ball of string and candles. We took off our shoes and stockings, rolled our trousers up, and slithered off through the bat dung. My companions were Professor J. Lewis Bremer and Eliott Bacon.

We went on and on, stirring up myriads of bats, creeping along at times where there was only a three- or fourfoot space between the surface of the guano and the roof of the cave. Then, farther along, we could just squeeze through a crack a couple of feet wide and forty feet high. Finally, when we were about tired out with the fetid heat and the mean going, we reached a deep, sluggish stream of water - water that had filtered down, most of it, through the lime rock, so that it had become supercharged with lime salts.

In the course of ages enough salts had been given up to form a crust on the surface of the water like thin ice on a 
pond in autumn in New England. We cracked this, carefully slipped the sheets of lime rock aside, and then could look down by the rather feeble light of our candles into a crystal-clear pool. There, to our delight, we could see numbers of pure white, quite obviously blind shrimps - new, too, to science! - swimming tranquilly about.

We collected a series of these in a dip net and then, to our delight again, found around the margin of the pool little sow bugs, or pill bugs, as we often call them here in New England. You see them here about Boston, slatecolored, swarming under brickbats or old boards in farmyard or garden. These, too, were pure white and completely without eyes. We bottled a supply of specimens and then retraced our way, winding up our ball of twine and making a good collection of bats during the return trip. It was a pleasure to get back to the surface and to breathe fresh air again. We clambered up the strangler fig by which we had descended, mounted our horses, and rode back to Madruga.

Cuba is honeycombed with caves. There are innumerable places where streams disappear underground. After the most torrential rainfalls many areas show no standing water at all. And, of course, the story of the marvelous Bellemar Caves at Matanzas is well known. A Chinese was working here with a crowbar, making holes in a rocky area to set out sisal plants. All of a sudden, after a particularly lusty stroke, his iron bar slipped from his hands and disappeared This is the way these famous caves were found, and now they are entered by a long flight of iron stairs lit with electric lights, and enchant with their beauty thousands of visitors from all parts of the world. 


\section{CHAPTER VIII}

\section{Cuba}

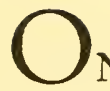

N OUR first trip to Soledad, Cuba, arrangements had been made for Rosamond and me to stay with a Captain Beal at Guabairo. He was a retired Danish sea captain who had charge of the colonia or section of the plantation with the lovely name, "The Whippoorwill." We went over from Soledad on a track car and walked up to the house. It was late in the afternoon. We ensconced ourselves very comfortably, found that evening that the captain had a most excellent cook, and looked forward to what the morrow might bring.

We arose early to a hurried breakfast and set out afoot as dawn was breaking, that loveliest time of a tropic day. Wisps of fog were rising from the fields of cut cane. Far away on the horizon a feather of smoke could be seen above the tall smokestack of the mill of the adjoining plantation, "Hormiguero," where we knew that before long Doña Luisa Ponvert would be having her armchair brought out to where her highly efficient eye could survey the trains of cane coming in and the sacks of sugar pouring from the centrifuges, as she had managed this great plantation for many years. The house at Guabairo was on the edge of a rough, scrubby woods, which grew on soil so rocky that it could not be put into can: but was useful for producing fence posts and firewood for charcoal.

It had rained during the night, and we turned and walked 
down a long lane bordered by the living fence posts so characteristic of Cuba. Fence posts here are placed in the ground to sprout and grow, and so are protected from the ravages of termites. I remember that the bien vestida or well-dressed lady - Gliricidia - was in bloom, and there were gaudy orioles pecking at the blossoms on the piñon posts - rich crimson flowers of an Erythrina. In the spring the hedgerows built of the Gliricidia are masses of pale mauve flowers, not unlike wistaria. These make the roadsides gay with color, for an enormous number of the tropical trees planted for roadside shade or for ornament are of somber dark green, a green far darker than we are accustomed to see here in the North.

We walked on until we reached the woods. In Cuba, you do not find a beech grove or a maple swamp or a clump of pines, as elsewhere in the tropics. There may be trees of a hundred different species in an acre, and as Spanish has absorbed much Arabic, so Antillean Spanish has absorbed far more Indian terminology than our English has done here. I often love to mouth over the sonorous Indian names of the trees we found about us. Are they not very lovely - ocuje, caoba, jucaro, yayajabita, acona, yaya, and innumerable others? I do not think we had been more than half an hour from the house when I found a rather damp spot in the woods where there were a lot of loose flat stones. I began turning these over and before long was entranced to find a number of tiny frogs, rich maroon in color with golden-yellow stripes which ran from the tip of the snout down each sice of the body. These were indescribably lovely little frogs, scarce a quarter of an inch long from stem to stern, and I knew at once that we 


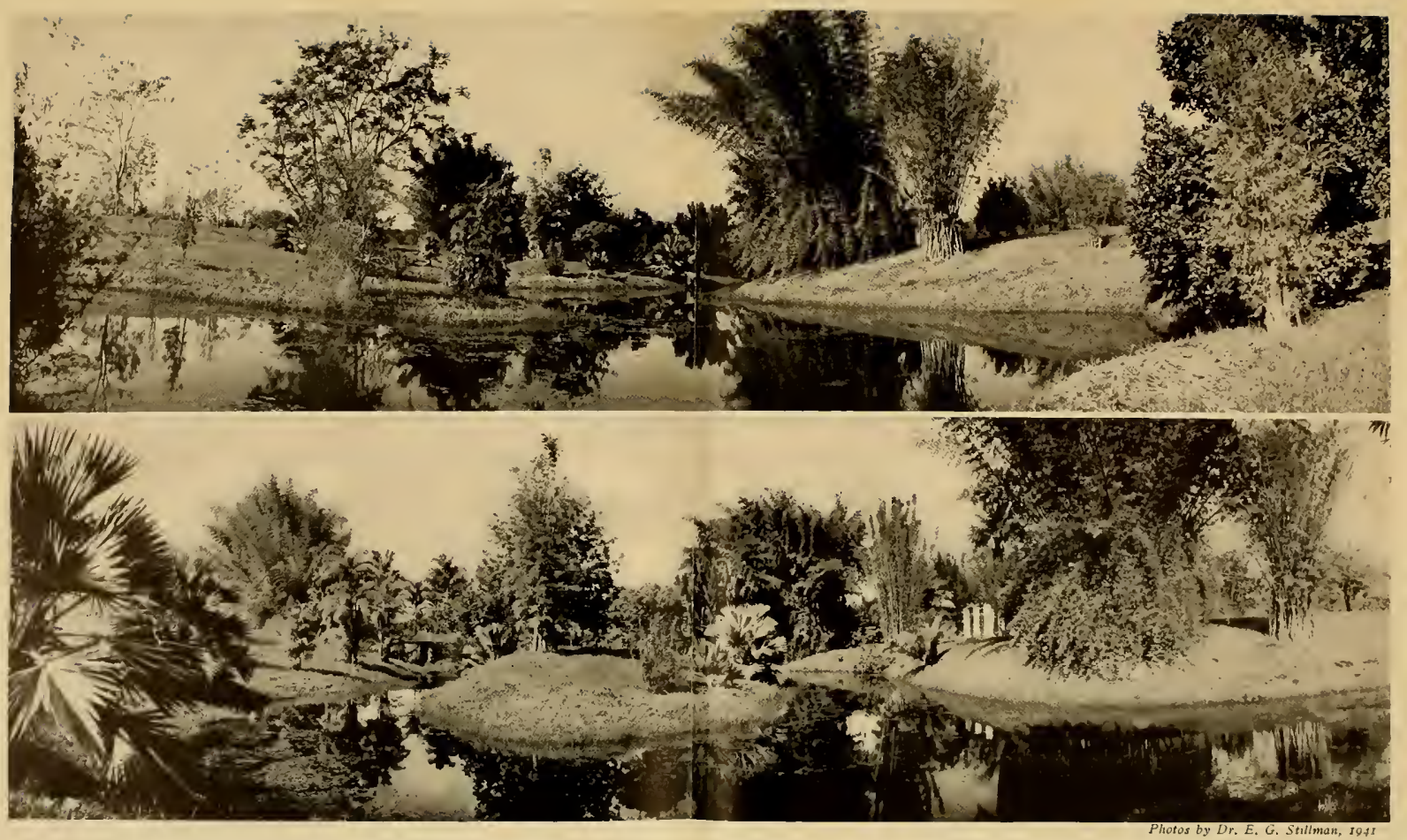

The Harvara Garden, Soledad, near Cienfuegos, Cuba 



\section{$C u b a$}

had rediscovered Pbyllobates limbatus. This particular frog had been lost sight of for sixty years. Cope in 1862 described it as originating in Cuba. But Stejneger and I suspected that it was wrongly labeled and that its home was Central American, not Cuban. Now we were proved wrong. We got a good series, and it was well that we did, as the type specimens in the U.S. National Museum from which the species had been originally described were dried up and worthless.

We collected other things - I remember a new freshwater crab - but the finding of this lovely little frog, the smallest frog which I know of in the world, was certainly the high light of this particular journey to Cuba. Later I found that they were quite abundant in the rocky area which we keep as a wild plant preserve in the Botanic Gardens and there countless students have had a chance to collect and observe this charming little creature, whose life history was finally worked out by Dr. Dunn.

Years earlier Stejneger and I in our conversations concerning the Cuban fauna doubted the locality of another creature taken there years before by Don Juan Gundlach, a German naturalist long resident in Cuba. Our doubts concerned the little lizard of a very archaic family whose representatives are rare denizens of scattered localities between the southwestern United States and Panama. We should have known better, as a matter of fact, for old Don Juan Gundlach did not make mistakes in the localities of the species which he described. He said this came from Cape Cruz, the extreme southern tip of the island. To verify this Don Carlos de la Torre and I set out on a survey trip, 
he to collect mollusks and I to see if I could turn up Cricosaura.

We went to Manzanillo and then by launch down the coast to Niquero, where we got a sailboat to go to the Cape. We were late getting started, and of course the wind died out. So our boatman and I rowed Don Carlos until about midnight, when we found a landing place behind the hook on which the great lighthouse stands. Our journey was delightful. The sea was as calm as calm could be, phosphorescent, like molten silver. I believe we could have read a book by the light produced each time we dipped our oars, and each fish that darted from our bow was like a meteor in the sky.

Once a pez agujon, one of those hopping billfishes, came skittering along on its tail, half out of water, and struck the gunwale of our boat. If it had been a few inches higher out of water it might have injured one of us badly, for these long, slim fishes (this one was two and a half feet long), with a beak like an ice pick and curious bright green bones, propel themselves with incredible speed. This one had been frightened by a porpoise or by a larger fish, and came skittering right against the side of our little dinghy. Of course we carried no light, as that would have invited visits from other billfish.

We came ashore to hear the clanging of iron shutters. The lighthouse keepers, who had heard the bow of our craft scrape on the beach, were taking no chances, and we sat outside on the concrete platform around the lighthouse for a long time before Don Carlos finally persuaded them that we were not bandits. In due season we were taken in and given hammocks. The next morning, bright and early, I was 
out rolling stones, and within an hour had turned up a tiny, slender lizard with a coral-red tail, which was very obviously our long unknown friend Cricosaura. I saw several others, but they were fast little devils and I got only the one. However, this one was as good as a thousand in establishing the fact that Gundlach was right. This creature has one of the most restricted ranges of any reptile in the world, being confined to an area in the immediate neighborhood of Cabo Cruz, not much bigger than Beacon Hill in Boston.

To me there is something particularly appealing about the scenery of the Cuban countryside. To be sure, the tropical vegetation is not breath-takingly inspiring, as is, for instance, that tropical forest which you meet between Puerto Armuelles in western Panama and the Costa Rican line. The wide sweeping cane fields, their dainty tassels blowing in the breeze, and the giant Ceiba trees, which are so often to be seen, since it is a custom never to cut them down, are a joy to the eye. These great umbrellas, their horizontal limbs each a garden of epiphytic curujeyes (plants growing on other plants), as the bromeliads are called in Cuba, are singularly pleasing, especially when the soft green foliage comes out with the first spring rains. Then there are the wide groves of stately royal palms, their pale gray stalks like stone columns surmounted by a section of polished green from which the long, graceful fronds sprout forth. These are used for thatching and the berries are gathered for pigs. There is a law against cutting them down, since the royal palm is the official emblem of the Republic. 
Cuba has been cleared for cultivation probably as extensively as New England was a hundred years agp and little of the land has yet begun to go back into second growth, as a large part of New England has already done. Cuban soil is unbelievably fertile and there are many fields on which cane has been cut for a hundred years without replanting. Indeed, I know a valley west of Havana where the topsoil is sixty feet deep, and while I miss now the high forests which I used to see on my visits to Cuba thirty or more years ago, I still enjoy the plantations of mango and other fruit trees which are found far and wide about villages and sugar mills.

The mango is one of the finest shade trees of the whole world, and the tender roseate hue of the long drooping leaves on the new-grown shoots is singularly lovely. It is strange how many tropical trees have this habit of putting forth quick-growing shoots with long, limp, slender leaves, pink or even bright red in color, which finally harden up and become the firm, typical adult foliage of dark green. I think of the Browneas, with their great red pompons of flowers, delicate little trees and hard to grow, and of that most glorious of all the flowering trees of the entire world, Amherstia, which we cannot make grow in Cuba. We only flowered it once in Soledad. Perhaps you may have seen it at Castleton Gardens in Jamaica or in Trinidad, or best of all in its native home in Burma. The flowers are borne each like a tiny bird mounted on a wire and each wire attached, as it were, to a long strand which hangs down from the end of the limb, each little bird crimson, with boldly painted golden spots.

Unfortunately Amherstia, even in Burma, seldom, if 
ever, sets seeds, and the little plants obtained by inarching or layering are extremely delicate. Thus its introduction into Cuba has proved very difficult because the atmosphere there is so dry and the rainfall so scant. All in all we have brought six or eight plants to the island but none survive today. I remember one really fine, well-grown plant given us at Jamaica when I was on the Utowana. Mr. Armour agreed to carry it direct to Cienfuegos. We did. A drop of salt water splashed on it while we were taking it ashore to Soledad and withered one of the main branches of the plant in an instant. However, the trunk and other branches were untouched and we found a damp spot for it under a giant Pithecolobium tree. This plant lasted for several years and flowered once, but was ruined with its giant protector by the hurricane of 1934. This was a sad blow. We have never since been able to secure a really well-established specimen.

Thanks largely to David Fairchild, Florida is beginning to provide us with good mangos, good alligator pears, and many other fruits long since staple articles of food in Cuba. Personally, I look forward to the day when we may have in our market here sapodillas. In the Spanish-speaking countries we call them sapotes or nisperos. They are "dillys" in the English-speaking colonies - fruit unprepossessing in appearance with a brown skin a good deal like a potato, though without eyes, of course. But break it open and the delicious brownish pulp has a delicate flavor of its own and the black polished seeds characteristic of the family to which the fruit belongs are quite artificial-looking and decorative. The Mamey colorado belongs to the same family, but this has never been established in Florida, 
although I believe there are one or two trees growing in Key West. This is a delicious fruit, which I believe some day we may expect to procure in Northern markets, almost as large as a Rocky Ford melon, the pulp bright red, with a delicious custardy flavor.

Who has not read Turtle Eggs for Agassiz? I have read it time and again. The yarn I am about to tell has no such charm. George Howard Parker was the best lecturer to whom I ever listened as an undergraduate, so I was naturally inclined to help him when he asked me for a boa. He wanted the longest unbranched nerve which he could lay hands on, to study the elaboration of carbon dioxide under electrical excitation. I was going to Cuba. With luck, I might get a large boa. When it was anesthetized and put under water, the long vagus nerve being dissected out and electrically stimulated, bubbles of carbon dioxide could be readily caught as they issued from the water and their volume measured. Now the vagus nerve activates the diaphragm and the diaphragm of a snake is well aft. Moreover, this nerve is unbranched. Parker yearned for a boa.

Before long I found myself at Soledad, in Cuba, and I passed out word through the countryside that I was interested in getting a large Maja, as boas are called locally, and was not in the least interested in small ones. Soledad in Cuba is the site of Harvard's only little ward of Paradise, a lovely botanic garden which I have been privileged to visit for years. While I was sitting on the front porch of Harvard House one hot and sultry afternoon two countrymen came up to the door, politely doffing their hats, and 
took from their shoulders a pole from which a large sack was suspended. The spokesman of the twain indicated that the sack contained the father of all boas. It wasn't long before we struck a bargain and the snake was mine. I dumped him out of the sack in the dark room, a little detached stucco-and-concrete building adjoining the laboratory. It was obvious at first glance that the snake had dined sumptucusly and I was not surprised when looking at him the next day to see that excitement or nervousness had given him indigestion, and a pile of highly aromatic corruption on the floor indicated that not long since he had consumed no less than three butías. These savory rodents abound in the wilder parts of Cuba and each one of these was about the size of an able tomcat. I got the hose and the broom and went to it, slicked the place up, and the buzzards took care of the situation in a few moments.

Time to leave. With some help, I crowded Epicrates, as I may call our victim, for this is his generic scientific name, into a strong carton, the kind that has four flaps, one on each end and one on each side, pressed them down, and tied up the bundle. I was forced to spend a few days in Havana, and Epicrates resided under my bed in the Inglaterra Hotel. The next day I crossed to Key West. Prohibition was in full swing and no customhouse official was going to pass a carton on my mere statement that it contained a snake; but one peek settled the matter and the bundle was re-corded and carried to the train. I had the southernmost lower in the north-bound car for Palm Beach. We left in the evening and the car was to reach Palm Beach early the next morning and to be placed on a siding for the convenience of its passengers. 
I walked around Key West to kill time, got aboard, and turned in about as the train was leaving. I went to sleep. I am a very light sleeper, and slept perhaps a little more lightly than usual on this occasion. At any rate, in the dead of night I heard a sudden sharp yelp. I knew at once that something was wrong and I reached over and twiddled the carton. It was obviously empty. Nothing to do but wait till morning. The hours dragged, but finally daylight came. I waited patiently until everyone had left the car; then I went and asked the porter what had happened. He said that he had been asleep in the men's washroom, having set his alarm watch so that he would have time to clean the shoes of the passengers who were to get off at Miami. He awoke and, lo and behold, there was the snake, which had escaped from my carton, crawled the whole length of the car and entered the men's washroom, where it frightened the Negro almost to death. Luckily, the diner was the adjoining car. The porter rushed in and got a cleaver, chopped the head off the snake, then opened the vestibule door and pushed it out. I pretended to be tremendously surprised. I was carrying the empty carton and told the porter it contained objects too fragile to entrust to anyone else.

After I had set it down and he had brought out my other impedimenta, I asked him how he could account for this extraordinary chain of events. He allowed he didn't know. I asked him if by chance he had left the car on the siding in Key West the day before with its door open. He said yes, he had. "And," I added, "you went up town sparking the gals." And again he admitted that I was right. I advised him that he should always shut the door of his car there- 
after. He assured me that he would never make that mistake again.

The history of the Garden at Soledad in Cuba has been written over and over again. The story of how Mr. Edwin F. Atkins acquired the Soledad Plantation is told in his book Sixty Years in Cuba, incidentally one of the best books on the island that have ever been written; how he consulted Professor Goodale and Professor Oakes Ames, got Mr. Gray to be Superintendent, hybridized sugar canes, and began the gradual accumulation of a collection of tropical plants over forty years ago.

I first visited Soledad in I909, and as I was specializing in a study of the fauna of the West Indies and for many years studied the fauna of Cuba intensively, I came more and more to avail myself most gratefully of the Atkinses' hospitality at Soledad Plantation. During the years of the last great war I was in Cuba all the time as a government agent and frequently spent week ends at Soledad. I became more and more interested in the possibilities of the place.

In time Mr. Lowell appointed me Custodian of the Garden and I have had to do with planning its development in a fairly intimate way for some twenty years or more. I have built dams and made ponds and watched their borders change from those of poor old worn-out cane fields to veritable fairylands. From time to time, until he died, I begged more and more land from Mr. Atkins, always with success, and since then from his son-in-law, William $\mathrm{H}$. Claflin. These friends have always given me wholehearted and enthusiastic appreciation of any plans I had 
to offer for the development of what is now one of the great tropical gardens of the world.

Harvard House, its laboratory, airy dining hall, and accommodations for six persons soon became outgrown, for while this offered sufficient accommodation for the visitors who came during the wintertime, in summer groups of students with an instructor began making increasing use of our facilities. So then Mrs. Atkins and I built Casa Catalina on the top of a high ridge looking out over the Garden to the Trinidad Mountains. Here there are a good big dormitory and several private rooms, so that now we can take care of as many students as we are ever likely to have.

Our collection of palms is only exceeded in variety by that of Colonel Robert H. Montgomery at Coconut Grove in Florida, and our ornamental and useful hardwood trees - teak and the like - are now big enough so that we can supply seeds to anybody who needs them. Soledad Plantation itself has flourishing forest plantings to provide future railway ties grown from our seed. For this Garden is not simply ornamental, but serves a useful purpose, introducing and testing economic plants from all over the tropical world.

One of the sure satisfactions of a life extraordinarily blessed with satisfactory events has been the many, many restful hours which I have spent alone watching the birds in a setting of entrancing beauty, a setting which changes every year. I thought the place was ruined when I saw it after the great hurricane of 1934 , but in 194 I, when last I was there, all signs of the hurricane were completely gone, such is the rapidity of plant growth in the tropics. The 
stately clusters of bamboo, the flowering trees of early spring, the ponds reflecting the magnificent trees which grow on their banks, afford scenes of extraordinary loveliness. Moreover, now there is a good road to our very door and one can motor out from Havana in about seven hours without unreasonable haste. As the beauty of the Garden becomes more widely known, the number of visitors increases, and anyone who is really interested in Harvard College cannot but be proud of its lovely outpost in Cuba.

Some years ago the University of Havana celebrated its two hundredth anniversary. After the party was over and the delegates had gone home, James Brown Scott of our State Department and I remained behind, for we had been told that a special convocation was to be held and we were to receive honorary degrees. I wired Boston, and my wife came down with my gown. No borrowed gown available in Havana would fit my bulk.

The fateful day was still and coppery hot - one of those spring mornings in the tropics when it wants to rain but can't and the trade wind forgets to blow. I put on my gown and fell in line. The ceremony was dignified and colorful in the extreme. Scott wore the red cape of a Doctor of Laws and I the sky-blue cape of a Doctor of Science. The placing of the biretta on our heads was the mark of the bestowal of the degree.

Scott went through his paces first, made a good speech, was orated at, and received the degree. He was just about the same size as the Rector of the University. Then came my turn. I made an oration in my most polite Spanish. My old friend, Don Carlos de la Torre, made me turn as red 
as a lobster by the things he said about me. And my wife, who was sitting in the front row before us buried in a mass of tropical floral tributes, blushed as Don Carlos recalled that the cannibals of New Guinea had said they preferred to look at her, which was why she was not eaten.

Don Carlos finally sat down, and I rose for the embrace. I stepped forward and put my arms around the Rector and patted him three times on the back, according to ancient usage. Well, when I did this he completely disappeared, for I am distinctly outsize, being almost six feet six in height, while the Rector was short even for a Cuban. A voice from the gallery said in Spanish, "There goes Cuba!" This was just about the time that the "Octopus of the North" was disciplining Haiti and San Domingo, for excellent reasons, and Cuba was inclined to take sides with its neighbors. However, in a second the Rector was unfolded and breathing again. I sat down, the biretta on my head, and as I did so the sweep of my ample sleeve tipped a gargantuan goblet of water into the lap of the Dean of the Faculty of Sciences, who was sitting beside me. He was extremely polite, but a little annoyed. I felt like an ass; in reality it was the proudest day of my life - the first really distinguished honor I ever received.

Now the scene changes. I am back in Boston and it is the Harvard Commencement season. On the Sunday evening before this event I sat in what was called the Sunday School at the Somerset Club, a pleasant after-dinner gathering. I was telling my friend Herbert Leeds about the Havana ceremony; I described the gown. This is of shiny, 


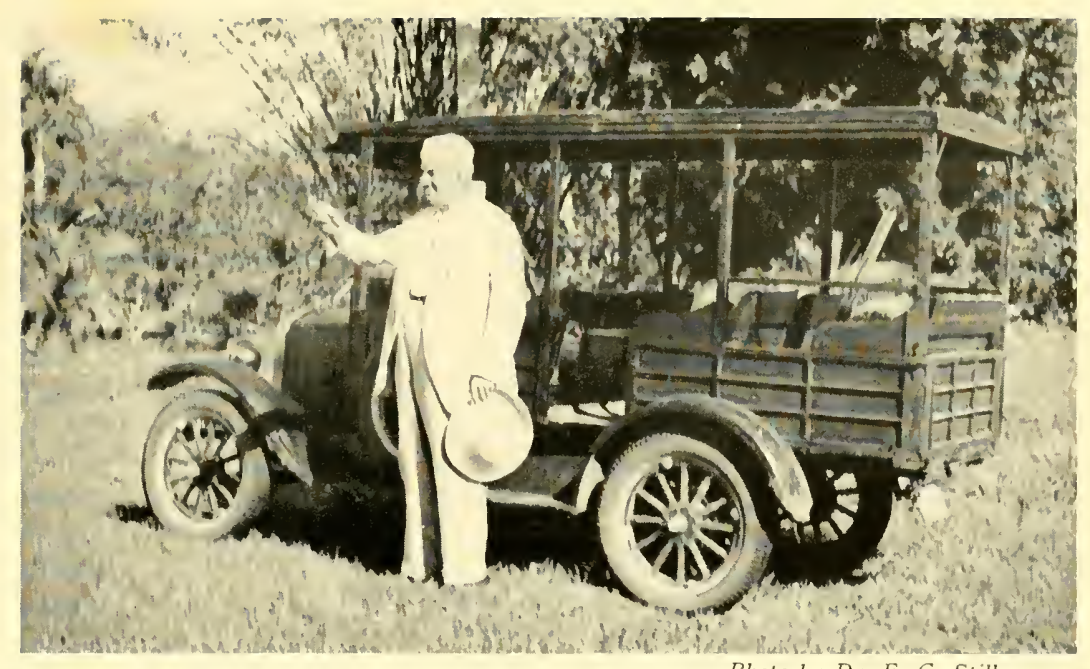

Photo by Dr. E. G. Stillman

The author and "Lizzie" at Soledad, I9f I

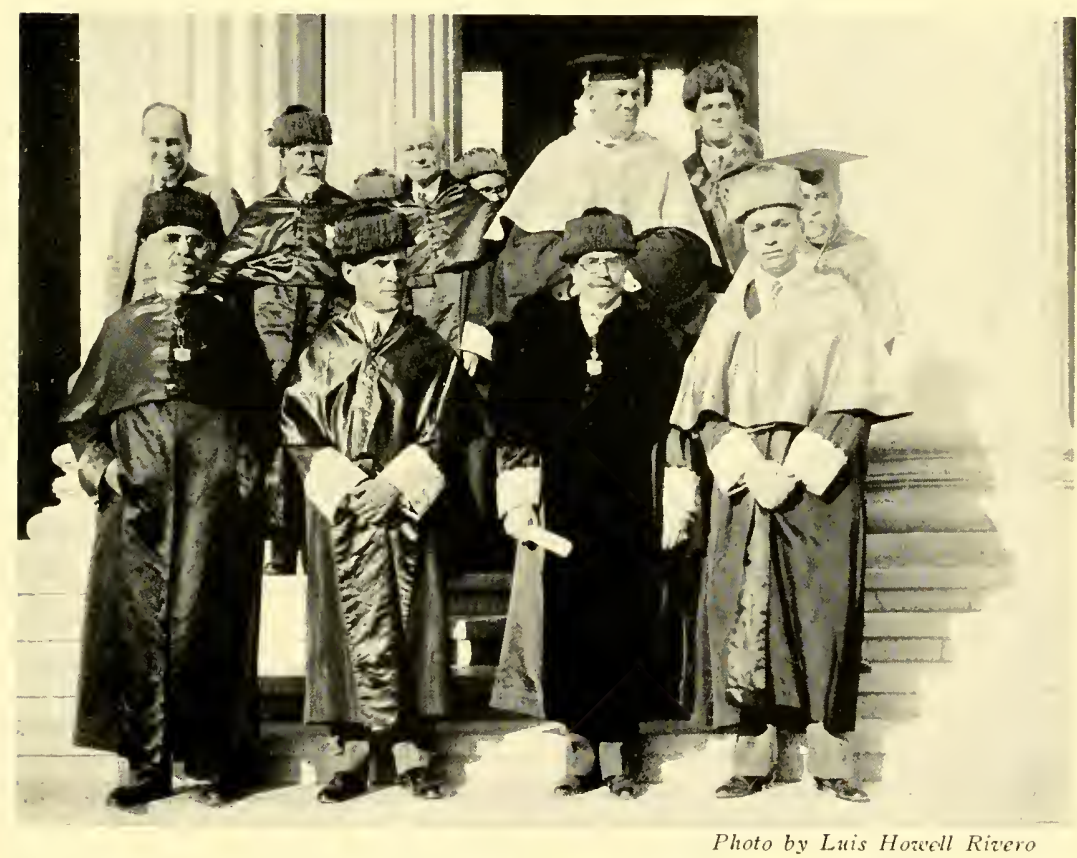

On the steps at the Aula Magna, University of Havana 

lustrous silk, full in the skirt but with tight sleeves, decorated with a deep lace cuff, white on the black. A sky-blue cape is worn over the shoulders, while the headdress or biretta is of blue silk with a large pompon of blue silk threads which reminds one somewhat of the rear end of a Pomeranian. Mr. Leeds said, "I have twenty-five dollars which says that you won't dare wear that next Thursday." I said, "You're on."

Commencement Day came. I went to Cambridge; put on my regalia. I was to be Marshal for the candidates for the degrees from A.M. to Theology; in other words, the second half of the candidates' procession. What I didn't know, however, was that because Harvard's ex-Treasurer, Charlie Adams, had been made Secretary of the Navy and was to receive an honorary degree, the press cameramen were to be allowed in the Yard for the first time in history. A platform had been made at the corner of University Hall on which they might stand.

Ten o'clock struck, the band started up, and Roger Merriman led off the A.B.'s. All went well until Lewis Bremer and $\mathrm{I}$, with our second division of the procession, reached the front of the press stand. Then something happened; the line halted. A rich Irish voice, subdued but yet quite audible, said to its neighbor, "Who the hell is the big bloke wrapped up in the blue diploma?" The other replied, "I'll go and find out." He jumped down, ran a few steps to the Yard cop, and whispered in his ear. He jumped back to the platform and said in a very audible whisper, "His name is Barbour and he runs the Agassiz Museum." No. I said, "He looks like the Pope's mistress!" The rejoinder to that was, "Would you say Pope Boniface or 
Pope Innocent?" "There's nothing innocent about that face."

At this point, thank God, the line began moving. I marched on, unbelievably relieved. I vowed never to wear that gown again, though I have from time to time sported the blue muzetta with my ordinary American doctor's gown. This does not have tight sleeves with a deep border of white lace and a skirt effect that looks extraordinarily as if one were wearing a bustle under a Mother Hubbard.

I suppose if we wanted to indicate that a man had become a real North Carolinian we should say that he had tar on his heel. In the same way the Cubans speak of a person as being aplatanado, that is, "bananaed," to indicate colloquially that he has become pretty completely acclimated. Well, my Cuban friends say that I am "un bombre bien aplatanado." Personally, I consider this a great compliment. If I grow loquacious and prolix when it comes to talking about Cuba I do not care a rap, for I love the country with a deep, passionate affection. I have no hesitation in saying so, and I do not care whether my friends believe it or not. My Cuban friends do, and that is all that counts. 


\section{CHAPTER IX}

\section{The Bahamas, Old and New}

I

HAVE been asked more than once why I have devoted so large a part of my life to studies connected with the Bahama Islands. The answer is that I have been governed partly by sentiment and partly by chance. The fact that Allison Armour liked to cruise in the Bahamas gave me a number of opportunities to visit islands which were normally inconvenient of access and I was swayed by sentiment because it was here that my grandmother first introduced me to the tropics, an experience which, as I have explained, played a very large part in determining my life's work.

The Bahamas are a happy hunting ground. To be sure they have a depauperate fauna but the question is, was that always so? I think the answer is no. We know from early historical accounts that some of the islands were forested and there are other reasons for believing that this was the case. Many a stately gateway now standing in what is pitiful scrub vegetation on rocky sterile soil is the only remains of the rich sea-island cotton plantations which existed before the days of British emancipation. I imagine that probably even before this time the temptation to clear land with fire had initiated the work of destruction. Burning and reburning have consumed the humus and most of the islands are now desolate indeed. If only the cave earth had not been so rich in fertilizing value that 
almost every single cave had been cleared out long ago we should have had an immense amount of evidence not available now.

What would I not have given to have had a chance to sift the earth out of those caves before it was all dug out and spread over the land! Recently a schoolteacher on the island of Exuma sent up to Cambridge the contents of a little pocket in a cave which had been almost, but not quite, emptied of its cave earth. This contained the bones of a number of fossil birds which when submitted to Dr. Alexander Wetmore, the director of the National Museum and our first authority on fossil birds, showed the presence long ago of species now extinct, and a genus, also, of birds completely tied up with a high forest environment - and yet we had only a tiny and pitiful sample for study. In the same way on half a dozen scattered islands I have found little remnant pockets of undisturbed earth which showed the presence of extinct forms of a genus of rodents of which today there is only a single remnant, the little population of guinea-pig-like rodents on East Plana Cay.

These little rodents are of the genus Geocapromys, and were probably once very much more widespread than they are now. One species is confined to the high mountains of eastern Jamaica and is very scarce. There was one in Cuba which is now extinct but of which I have found remains in many caves. Then there is another which swarms on Little Swan Island off Honduras, and of course the one which I have mentioned as occurring on East Plana Cay. There is no indication whatever that it ever occurred on the mainland, which may seem a surprising statement in view of the fact that I speak of one occurring on Little Swan 
Island, but these islands in the Bay of Honduras have a mysterious Antillean tinge to their fauna. When the Utowana stopped at Coxen's Hole at Ruatan I found there a tree lizard (which I call Anolis allisoni for our gracious host) which was closely allied to a species of Anoles with representatives on the Cayman Island, Cuba, Jamaica, Haiti, and the Bahamas. This group of lizards is so sharply set aside from the scores of others in the same genus that it almost deserves a generic name.

Allison put David Fairchild, James Greenway, and me ashore on East Plana, where as usual we made a grand haul of the land shells which abound everywhere in the Bahamas, and where also we collected some fine specimens of $G$. ingrabami. These were the only specimens which have been taken since the types were secured long ago. The remains in the caves may mean that these little rodents were eaten by the early inhabitants of the islands. Recent explorations have greatly increased the number of animals known to have existed on all of the Greater Antilles, but this evidence has mostly been derived from undisturbed caves or from caves where dripping supercharged lime water has formed a breccia that has protected the bones by encapsulating them with lime.

The northern Bahamas with their flat pine-clad plains probably never had a very varied vegetation; I suspect they have always been much less fertile than the southern Bahamas which supported what we know was a spacious and gracious plantation life. Planters could once afford to send their own horses to faraway Jamaica to participate in the big races there, but today the islands are completely poverty-stricken. The answer is of course fire. After eman- 
cipation days the planters perforce moved away and the freed slaves, being left behind, took the easiest way and as land grew up to brush they cleared and recleared by burning it off, until now on such islands as Cat Island, Long Island, Crooked Island, Acklins Island, Eleuthera, Exuma, Mariguana, and Great Inagua, only the most pitiful remnants of gardens remain. The considerable population naturally has to support itself to a large extent from the sea.

Many of the resident birds peculiar to the islands are extremely local and restricted in distribution. I think particularly of the beautiful Nye's woodpecker. This occurs in a sort of swale in the Victoria Hills Section of Watlings Island. Here there is a growth of large gumbo-limbo trees (Bursera guttifera). The area is so restricted that I doubt if the total population of this lovely species amounts to more than thirty to forty pairs. These big trees are no doubt a good sample of what once grew more or less everywhere. Elsewhere the forests were weakened by fire. The big trees not actually destroyed by the fire itself were removed by the devastating hurricanes which pass over these unfortunate islands more frequently than elsewhere.

How have the creatures moved from one island to another? The number of genera of reptiles with representative species on the various islands is really very considerable. However, I think this not really difficult to explain. There has been some fortuitous dispersal by flotsam and jetsam motivated by hurricanes no doubt. But during several glacial epochs when a large quantity of oceanic water was tied up in the form of polar ice the surface of the sea was certainly lowered sufficiently to change the Bahama Archipelago to its present condition. I believe this made large 
land masses of what are now groups of many separate islands. I also believe there may have been a lot of downthrusting of fault blocks in the Bahamas. It is impossible even to guess when this occurred but there are many reasons to postulate isostatic disequilibrium in the whole Bahamas-Greater Antillean area.

I agree with those geologists who believe that the Yunque of Baracoa in Cuba (well-named the anvil because it is a great steep-sided block of a mountain) and the similarlooking Morro of Monte Criste in the Dominican Republic are upthrust fault blocks, and the channels between the islands with their steep walls dropping off quite close to shore are perhaps compensatory downthrust blocks. While the Bahamas are flat the Greater Antilles are mountainous. A vast predominance of limestone has gone into their make-up. Of course this limestone has made possible the perfectly unbelievable variety of mollusks that are to be found there. Hundreds of valid species have been described and the end is not yet by any manner of means. Collecting mollusks in this part of the world is a most fascinating pastime. The species, many of them, are unbelievably beautiful and although they have a tantalizing way of disappearing in dry weather it only takes a shower or two to bring them forth in utterly incredible swarms.

I had an opportunity to visit the island of Great Inagua on several occasions. Matthewtown, its principal settlement, was a dreary relic of what once obviously was a place of some importance. The great salt pans behind the town were interesting only because of the presence of a few straggling flamingos, while the animal life of the island had 
suffered from the introduction of a more curious job lot of beasts than most island faunae have to cope with. Feral cats and rats abounded; also donkeys, wild cattle, and, I have heard it said, even hogs and horses. At any rate the scrubby vegetation surrounding the great saline ponds in the middle of the island reminded one a good deal of East Africa as a drove of timid jackasses would scamper off ahead of the intruder.

James Greenway, who was much more agile than I, succeeded in landing on Sheep Cay, a tiny isolated remnant of the greater islands separated by but a short strait of salt water from Inagua itself. But this stretch of salt water had saved the day as far as I was concerned, for Jim waded out to where we could pick him up, carrying a canvas bag which he had taken ashore, and which now contained two treasures. One was a handsome little species of boa which turned out to be completely new, the other a very distinct Alsophis. I suspect that these once were abundant all over Inagua and that they have been extirpated by the introduced vermin. At any rate as far as I know no one had ever found them on the large island and it had been visited by a number of naturalists.

Now comes the remarkable part of my story. William, Josiah, and Douglas Erickson made a careful scientific search of the possibilities of utilizing the old salt pans, and through Josiah (whom we all call Jim, and who was one of the first of my many honorary nephews) I have been able to keep track of what these wonderful young men have done. To be sure the name of Erickson is synonymous with ingenuity. Think of the Monitor in the Civil War and the screw propeller on every steamer. I need say no 
more. I wrote Jim and asked if he would be willing to tell the story of what he and his family have done with Inagua. Here it is: -

West India Chemicals, Limited Matthewtown, Inagua, Bahamas February 14, 1943

Dr. Thomas Barbour, M. C. Z.,

Harvard University,

Cambridge, Massachusetts.

Dear Uncle Tommie:

Sorry to have had to delay this but the pressure of work has been considerable and time has just not been available. You asked for an account of the changes which have taken place here since your last visit and I will try to give you a rough picture of what we have had to contend with and what developments have taken place.

You were quite familiar with the physical aspect of the town as it existed upon our arrival. To go with the picture of an almost nonexistent standard of living, we found the usual accompanying lawlessness, an attitude which was shared by practically all individuals of the local population. Everyone was gathered more or less tightly under the leadership of three or four individuals who tried to hold local superiority by means of an apathetic sort of gang warfare. The one business was that of stevedoring on steamers plying to South America and Europe. As Matthewtown was a port of call for several steamers each week, there 
was a considerable turnover in the resident population.

It was the general practice of all local leaders to have a man's total wages for a coming trip completely swallowed in trade before that individual ever embarked. This practice definitely assured the men that they would earn nothing if they depended solely on the rewards of honest labor. Thievery of cargo in vessels' holds and, for the more daring, from warehouses in southern ports, led each individual to a common understanding that the only way a man could possibly profit was by dishonest means. The resultant situation on Inagua was that of men vying with one another to show their prowess at various forms of gangster technique. This was evidenced in a blatant, bawdy sort of life in which Saturday-night wife beatings, drunkenness and various rather futile attempts at knifing were the common order of the day.

It was a particularly unsatisfactory situation in that no one valued money as such, and no one seemed able to conceive how they might be benefited by what we think of as a higher standard of living. A standard of living to them was nothing more than an abysmal poverty which had its one soul-satisfying outlet in boastfulness of how tough one could be. No one was anxious to earn money in excess of that required to fulfill the most meager purchases of food and clothing; all the so-called luxuries such as cheap rayons, silks and gaudy wearing apparel having been acquired through the aforementioned pilfering. No one dreamed of having money in terms which could possibly mean a decent house to live in and, for that matter, even a decent 
bed to sleep in. No one thought of money in terms of food other than rice and grits. No one thought of children's schooling as a large percentage of the population was illiterate.

If you paid a man the miserable daily wage of 50 cents, he would probably work six days out of the seven. If you were sufficiently insane to pay him $\$ 1$.oo a day, he most certainly would not work more than three days per week. In other words, there was no means by which one could stimulate a desire for education, for better food, for better housing or for better anything. Everyone was at zero level, and having always been there were perfectly content to remain there. I could only think of the story which one of my professors at Tech used to tell about the manager of a sawmill in Arkansas who was faced with the same problem when executives of his company, having offices in Chicago, decided that wages in the Arkansas mill should be doubled. The result was a halving of production as it is simple arithmetic that if you get twice as much you need only work half as much to get the same net result. As the story goes, the manager solved his difficulties by a present of a brilliant red silk dress to the boss Negro's wife, at the same time supplying a stock of similar dresses priced at fabulous figures to the commissariat. Within the week feminine desire not to be outdone drove reluctant husbands and aspiring swains to a full six-day-per-week schedule of operation.

It was an example that was difficult for us to put into effect in Inagua as the light tinsely trappings that 
fulfilled the population's desire for adornment were all to be had in ample quantities simply at the risk of a little daring. To turn to the more solid things of life such as greater creature comfort in the form of homes, etc. was so remote from hope of attainment that we could induce no individual in the community to as much as attempt to struggle for same. It took years of carefully planned control - control of lawless activities while men were on shipboard, control of local commodity buying and selling, control of living conditions, and virtually the way of life before we had the final satisfaction of seeing personal initiative, the rudiments of self-respect, and something closely akin to character begin to develop on the island.

To counteract exorbitant local prices for food and clothing, we found ourselves with a general store on our hands, we bought in bulk at wholesale prices and resold at a price just sufficient to defray overhead. We found ourselves running a restaurant business, a rudimentary housing project, a medical clinic, and many similar organizations, all of which slowly and painstakingly began to have their respective influences on the wants and opinions of the public.

New types of food were edged in at the store, were sometimes given away as gifts with other purchases, and ever so slowly new tastes were cultivated for nutritious, healthful foods that had never before been tried or tolerated on the island. In the same way our restaurants provided meals in which our company absorbed the major part of the cost, so that regardless of whether some of the dishes served were new, 


\section{The Bahamas, Old and New}

and regardless of whether they were particularly liked at first, the general run of the men found that they got so much for so little that they could ill afford to provide their own wretched type of meal for which they had a natural liking in place of the more properly balanced meals which were somewhat strange and under normal conditions would be unacceptable to the uninitiated palate. Through better feeding our men have found that they are less prone to sickness, that they are less susceptible to cold, and that they have a greater abundance of vitality than ever before.

The same has been true of our attempts at proper housing, of our attempt at maintaining a proper clinic, where it is now quite plainly evident that the benefits received are worth while, that they lead to actual greater enjoyment of life, and we have in the making a tentative acceptance of the fact that a higher standard of living is something worth striving for, that although to be industrious requires a considerable expenditure of personal effort, the returns from such industry begin to lead toward something approximating home life, toward an atmosphere less laden with the wretched squalor and misery that was so generally accepted as being the only form of life obtainable.

Concurrently with this slow awakening of interest we have carried on an educational program which had its foundation in our garage and maintenance shops where our youngest and, per se, most intelligent labor material was started in chipping rust, cleaning machine parts and finally, though slowly, learned not only the 
visual aspect of the inside of a piece of machinery but also learned something about the value of caring for that equipment. From this stage they were carried to that of learning to drive trucks, run pumps, operate power shovels, drive tractors - in short, carry on practically all the mechanical operation of our plant's equipment, and that, too, with a considerable degree of skill and success.

Imperceptibly this group of men and boys were the forerunners of an upper class in the island's native society, a class which had heretofore known no marks of distinction, no gradation of education, no differential as to degrees of ability, all because the class as a whole were what was locally known in Nassau as being behind God's back. This awakening of class consciousness has been a stabilizing influence for the community as a whole. Just as the first group of truck drivers were looked upon by all and sundry as being people quite specially favored and quite admirable to emulate, so also have been the actions of this upper class of society. It is seen that they have better homes, homes which are tangible and possible of attainment. It is scen that some of this group are acting even now to get a better education. It is seen that this group as a whole are being invested with local authority and as such, shall we say, perhaps like the bureaucratic regime in Russia, it is a position worth striving for. Not only is the financial recompense appreciable, but so also is the standing which this group has in managing local affairs.

Our whole purpose in handling this group of Ne- 
groes as we have has been in an attempt to place them in a position where they will of their own volition develop themselves and make of themselves something more than goods and chattels, which are the perpetual care of government. I remember an old sea captain who in his training of a young lieutenant said: "Hunt him until he hunts himself and then ye'll no stop him." It is in this same sense that we have tried to drive, to push, to exert until such a point is reached that this group of fellows with whom we are dealing will take this momentum and carry it to greater speeds for themselves.

I can truthfully say that the Inagua group as a whole have begun to repay us for our efforts. The younger members in particular have developed some mighty fine characteristics. There is an esprit de corps which, I am sorry to say, I have not found equaled in any labor group with which I have had dealings in the U.S. There has been a conscientious effort on their part to enter into discussions on company affairs and, what is most gratifying, there is the general feeling that this is their company. If you as a stranger talked to one of our truck drivers or, for that matter, to any one of our employees, you would probably be told that we do thus or that we do so, simply because almost every individual now begins to feel that he himself is in some way responsible for the developments of this concern.

Within the year we have assisted our men in their formation of a labor union which it is hoped will have Sir Ernest Bevin's recognition. This is a long step 
to have taken in seven years from a time when local, self-seeking interests tried to drive us from the island by killing one of our men and wounding others. It's a long step to have taken in local mental outlook when you stop to consider that the newly formed labor union of their own volition took the name of "Association" instead of "Union," as to their minds the word "Union" symbolized a condition of strife and ill feeling between employer and employee and in this case it was their special wish that no such connotation should exist but rather that we should always feel that everything done by our concern should be an expression of extreme and loyal co-operation between employer and employee.

From the Inagua which you knew during your last visit I think you would find it strange to see a condition wherein a company labor union maintains its own clubhouse, has interest enough to desire educational features such as lectures, displays of laboratory experiments, health talks and, in short, practically everything pertaining to that higher standard of living which was such a far cry when we first landed on the island.

Of equal interest to this development of an erstwhile uneducated, totally forgotten group of people is the development of the natural resources of the island which not only made the foregoing possible but also, what is more, practical. Originally the island produced a fairly large quantity of salt by means of solar evaporation. This commodity was shipped almost exclusively to the Eastern Seaboard of the United 
States and Canada. With the development of the salt mines in New York State the price of salt fell from about $\$ 30$ a ton to a figure little more than $\$ 5.00$. With this decline in price little effort was made to alter manufacturing methods sufficiently to keep the then existent companies solvent. Each followed the other in a succession of bankruptcies until the industry was totally at an end. In our own case we have been fortunate enough with certain new developments to make the manufacture of solar salt a successful undertaking. The salt now being produced at Inagua is of extreme high purity and for the most part all that is shipped from the island is of C.P. grade. In other words, our main attempt has been to get away from the old methods of solar salt manufacture which almost invariably precluded bulk shipments of a chemically pure product and in many cases went far in straining the fair limits of Technical Grade.

What was known on old maps as Lake Rosa, a desolate mud flat of a lake which was the breeding ground of a dying flock of flamingos, has with its new name of Lake Windsor become the chief object of company development. Vast quantities of sea water are being pumped into this lake. Salt pans are now being built on what was known as the Savannah, roaming ground of countless donkeys, the progenitors of which were brought from Spain by Mr. Matthew Clark of London. Oddly enough, these donkeys were to be raised for use primarily in the salt mines in New York State.

To facilitate the operation of this new salt area, as 
well as a magnesite plant which is part of the new development, we have built a road from Matthewtown to Northwest Point. This road follows the shore up to Devil's Point where it cuts across and again touches the sea along the inner edge of Man o' War Bay. With the building of this road we have also completed a continuous stretch of dikes which join all the caps on the western side of Lake Windsor. On your next visit to our island I am sure you will find these embankments excellent vantage points from which to view the tremendous quantity of wild fowl which the lake now supports. The new salt water entering the area has provided the lake with a teeming supply of fish and small Crustacea which should greatly increase our even now sizable flocks of white heron, egrets, ducks and flamingos.

I hope this will give you some idea of the changes which have been taking place at Inagua in the last few years.

Ever sincerely,

JIM

This letter of Jim's is a monument of understatement. He has built up an enterprise unique in all the British West Indies. Built it up in the face of governmental apathy and of native ignorance that are almost unbelievable. Fortunately the Duke of Windsor gives him sympathetic and most intelligent consideration. The Ericksons and their families, who are with them, may indeed be proud of having revolutionized a community, revived an industry, built it to do a greater and better work than was ever conceived of when the industry began. 


\section{CHAPTER $\mathrm{X}$}

\section{Reptiles in the West Indies}

\section{ManY years ago I acquired a strong impression that}

the number of species of reptiles and amphibians on the Greater Antilles was distinctly limited, and for years I made the serious mistake of interpreting as indvidual variants, or different sexes, adults and young specimens which in reality have proved to be totally distinct species. A great deal of the proof concerning the true state of affairs is due to a former student of mine of whom I am inordinately proud, Professor Emmett Reid Dunn of Haverford CoIlege. But years ago in Cuba my friend Dr. Charles T. Ramsden tried to set me right. He insisted that I was not recognizing a sufficient number of frogs of a certain genus when we were preparing to write a book together on the reptiles and amphibians of Cuba. ${ }^{1}$

I began to err in this way most conspicuously on our first trip to Jamaica in 1909. We went there after a rather long stay in the Canal Zone. We had been seeing a lot of the Gorgas family - the Colonel, as he was then, Mrs. Gorgas, and Aileen. We had all been to Chile together and when I came back to work in the Board of Health Laboratory at the Canal Zone, the General and Mrs.

${ }^{1}$ I know that I was unconsciously influenced by what Gunther and Boulenger had written when Garman multiplied the species of Lesser Antillean lizards. Time proved that Garman was entirely correct. 
Gorgas were hospitable beyond measure. When we went to Jamaica they passed us on to friends there, the Lagardes. I wrote my first paper which ever really amounted to anything as a result of the material we got in Jamaica. This paper would have been better had I known as much as I know now about the limitations of individual variation in amphibians, but even so, we spotted some good things and described them.

Most of these we got at Mandeville, a heavenly spot in the hills of west central Jamaica, where the Lagardes had a lovely house and where it was a delight to be alive and one keenly regretted the passing of each hour. The damp winds blowing over the hills in Jamaica cause a lot of rain and the growth of what are called "wild pines" is often extensive. These are what in our South are called "air plants," only more luxuriant and more abundant in species than the bromeliads of Florida. In the cup formed by the long recurving leaves of each individual wild pine plant is usually a half pint or so of water, and these epiphytes support a characteristic and extremely interesting fauna.

Our method was to spread a sheet on the ground, send up a Negro boy into the trees to throw down masses of the wild pines, and shake them vigorously over the sheet. All hands stood by, for Lewis and Mary Bremer were with us at this time, and Mary Clark as well. They helped catch the frogs before they escaped, and picked up such insects as did not appear too noisome. The venomous-looking critters were left to me and my metal forceps.

We had an amusing experience in Jamaica. When I was a sophomore in college I had visited my cousin Robert S. 
Johnstone, who was a judge at Nassau in the Bahamas. I knew that he had been transferred but did not know where he had gone. Years passed. Then at dinner one evening at the Gorgases', Sir Claude Mallet, the British Minister to Panama, mentioned Mr. Johnstone as being Colonial Secretary in Jamaica. I assumed instantly that this was my transferred cousin, little knowing that the latter had been knighted and sent to the Windward Islands to be Chief Justice. When we left Colon to cross to Kingston, I sent a cable to the Colonial Secretary saying, "Meet steamship Trent arriving such and such a date," and thought no more of the matter. When we got to Kingston I looked about for a familiar face, but in vain. Several hours were consumed while we scarched for the Secretary and he for us. The next day I called at the Colonial Secretary's office. After being ushered into the presence, for in British colonies the Colonial Secretary ranks next to the Governor, I found an irritated and rather awesome personage. I gave him a long explanation. He finally got a Colonial Office List, looked up, smiled broadly, and admitted that there was another person whose name was exactly the same as his own, even to the rather unusual spelling. Moreover, the fact that my cousin had been knighted showed that he was a person of repute. Mr. Johnstone asked us to his house and a most pleasant acquaintanceship ensued.

One of the most interesting animals in the world to zoologists is that creature called Peripatus. I use this name in a very inclusive way, for there are a lot of genera and species scattered over the world, all more or less closely related and all forming together a group of the utmost 
scientific interest. These creatures are wormlike in many respects, but with the breathing apparatus of insects and with the power of ejecting two jets of viscous and irritating slime from pores in the head when they are disturbed. Today they are well known and well represented in collections. This was not the case when first we visited Jamaica, but we knew that two species were known to occur on the island and were supposed to be extremely rare. We had almost nothing representing this peculiar group of animals in the museum in Cambridge and one of the special reasons for going to Jamaica was to get Peripatus. Dr. Michael Grabham was a distinguished physician in Kingston and an excellent amateur entomologist. I knew that he had collected a few specimens and went to him for information as to where they might be found. He advised going to Bath, where there was an old mineral spring and hotel of sorts. He said that Perips, as we call them, occurred only, so far as he knew, on the summit of Beacon Hill, a peak in the Blue Mountains to the top of which there was a path leading up from near the Bath Springs House.

Journeying in Jamaica in those days was a pleasant contrast to what it is now. We got a team of mules and a big three-seated canopy top at Port Antonio and drove leisurely along the narrow road to our destination at the east end of the island. The scenery was superb and the method of traveling permitted the most complete enjoyment of it. We reached Bath after a long day's drive, got ourselves settled and, fortunately, found exactly the right boy for a guide. During the ensuing days we made daily trips, Bremer and I, to the summit of Beacon Hill, where we 
scratched around in the banana trash and the holes in the ground out of which one could pull the rotten stumps of plants from which the bananas had been cut. By great good fortune we came up with a really wonderful series of the animals, whose peculiarities are not discoverable to the naked eye. They look like velvety brown caterpillars about two inches long. We killed them in hot water, which expanded and relaxed them, and preserved them for permanent study in various ways - a fine collection. We were well satisfied and returned to Port Antonio. There I assiduously collected an enormous series of sea urchins of the genus Cidaris, which Professor R. T. Jackson, my old freshman adviser, wanted for statistical study. As I remember it, we then spent several weeks at Port Antonio, awaiting a boat to Santiago, Cuba.

Several days before sailing Ros said to me, "I have a funny lump under my toe." I said, "Let's see it." The skin was tight and shiny over something which looked as if an acorn had been pushed under it. Without saying what I was going to do, I gave the thing a pinch and out popped a mass of little white animals that looked like chestnut worms, and which Ros declared had black eyes that actually blinked. Without discussing the zoological improbabilities involved, I washed the cavity where they had developed with formalin, which caused her acute discomfort but cured matters at once. I found out that while I had been absent on Beacon Hill the young ladies had wandered up the valley of a lovely brook, being extremely bored sitting about Bath, and having found a shady pool far up in the woods they proceeded to spend their days dallying about and swimming in puris naturalibus. And of course, 
while they were sitting about on the sand, a chigoe, or nigua, as they are called in Spanish, had crawled in through the skin under Rosamond's toe and proceeded to raise a brood.

As is my usual custom, I read the account of this episode to my wife last evening. This is worth-while insurance. She listened to me and then snapped out, "I think it's perfectly disgusting to write about such things. And anyway, it wasn't you; it was Lewis Bremer who poked those worms out with a nail cleaner." I shudder when I wonder what my dear old friend will say when he reads this, for he is a genuine doctor, and of course this was not first-class surgical practice.

I have been back to Jamaica a number of times since this visit, once or twice on the Utowana and twice or more on steamers of the United Fruit Company. I was usually inveigled into a stopover to visit another very old friend, the late Mr. Frank Cundall, a real antiquarian and a capital historian. Once I returned to Bath with Frank Cundall and David Fairchild and we found still standing a mango and a giant Barringtonia tree, which were the actual individuals brought back by Captain Bligh on his final and successful voyage for plant introduction. They had been planted when there was a botanical garden at Bath. Although he left some of his introductions in the garden at St. Vincent, I could not find any evidence that any of Bligh's trees were still alive when I was there several years ago. But there are two or three unquestioned survivors in Jamaica.

I have made so many journeys among the West Indies fifteen or twenty - that I have trouble keeping them sepa- 
rate in my mind. One of the pleasantest of them, however, came as a distinct surprise, and I am sure that my delight when I heard that Allison Armour planned to take the Utowana on a long cruise through the West Indies may be well understood. There were many islands which I had never visited, although I had studied collections made on almost all of them and I had a great desire to see those localities even for a short time.

This cruise was undertaken primarily to secure confidential information for one of the government departments in Washington, and I had a long list of seeds which the Office of Plant Introduction wanted me to secure in the Lesser Antilles for introduction into Florida. The zoological collections of vertebrate animals from the West Indies in the Museum at Cambridge are so complete that there was no object in collecting on a wholesale scale, but there were special things here and there that I wanted very much.

Actually more good accrued to the Museum than might have been reasonably expected. I will cite one or two conspicuous examples. For instance, we reached Pointe à Pitre in Guadeloupe not long after a devastating hurricane. The little local Natural History Museum in this town was long ago named for old l'Herminier, a French naturalist who first made known the fauna of this very interesting island and its dependencies. The roof of the museum had been blown off and his collection of birds left in pitiful condition. They had been removed from their cases and stood about the floor in the hope that they would dry out after the tempestuous rain which had fallen upon them. It took but a glance to see that l'Herminier's two specimens 
of the rare black-capped petrel were beyond saving. On the other hand four specimens of the local burrowing owl were in very fair condition. I arranged to make a substantial contribution to repairing the roof and took two of the burrowing owls. Our Museum had one already and with one of this pair I made an advantageous exchange with Lord Rothschild, which still left us with a pair. The bird is long since extinct.

A few days later a visit to the Island of Marie Galante made it quite evident that this little owl really had been confined there, never occurring on Guadeloupe. Marie Galante is low, flat and sandy, typical burrowing-owl country. Guadeloupe is high, mountainous, and heavily forested. It is a pity that the bird was named Speotyto guadeloupensis - one of the myriad unfortunate zoologic names which are misleading but which have to remain in use if we are to have any stability of nomenclature at all.

Incidentally I had a chance to see alive on Marie Galante, and indeed to collect, a series of the most magnificent of all the tree lizards - the genus Anolis. This Garman collected and described from this island when he visited there with Mr. Agassiz on board the Blake, over half a century ago. No one since had collected reptiles here and this was fine exchange material. It is strange that so many of these little islands which at first sight appeared to be but recently separated from their larger neighbors should support so many extraordinarily distinct lizards. The Anolis of Marie Galante is a truly beautiful lizard, and if there were not other species which more or less intergrade with the general run of the species in this enormous genus, it might be set forth itself as being generically distinct. 
A visit to Dominica brought a chance to meet $\mathrm{Mr}$. Joseph Jones, long the curator of the lovely botanic garden, and this meeting engendered a pleasant correspondence which lasted for years. On our visit to Grenada, I fell in with Father Gates, a descendant of General Gates of Boston Revolutionary fame, a naturalist and an artist of great talent. When he died years later I received a large album full of colored drawings of insects, plants, and other creatures, all of exquisite beauty, with a card saying "Sent at the request of the Rev. Sebastian Gates, O.P." I was touched by his thinking of me in this way although I knew I had made him very happy by fencing his little house and chapel at Piedmontaine to keep stray goats out of his garden. These exquisite sketches may easily serve to illustrate future publications of the Museum describing material from this enchanting isle.

Our visit to Port-of-Spain, Trinidad, was a great event, for I met then for the first time Fred Urich, with whom I had corresponded for years. Someone had just brought him a living tiny frog of the genus Amphodus, hitherto unknown from Trinidad, a lovely little golden-yellow creature, tiny but with eyes like jewels. This is found in bromeliaceous plants in the highest lands of the island, and he generously gave it to me to take back to Cambridge. $\mathrm{He}$ was always doing things of this sort. I visited him again several years later in his home outside Port-of-Spain, and was saddened later on when the news came of his death.

Herbert Stabler, an old friend, was living in Caracas, the representative of the Mellon oil interests. He asked me to stay at his house while some minor repairs were being 
made to the Utowana at La Guaira. His wife and sons were in the States and we were quite foot-free. Allison felt that he should stay on board the boat, only coming up to the capital from time to time for the day. Finally Allison set a certain day and suggested that we meet him in Puerto Cabello. From my point of view this arrangement was perfect, for it made possible a motor trip from Caracas to the port with visits to Maracay and Lake Valencia en route.

Maracay is one of the unique cities of the world. There is a great ready-made stronghold with a sumptuous hotel and beautiful buildings, all because the famous dictator General Juan Vicente Gómez disliked the climate of Caracas. Here he had his model farm and his extraordinary zoological garden. This was in charge of one of the younger members of the well-known Hagenbeck family of Hamburg, who by chance knew who I was. Herbert Stabler naturally knew Gómez well and at this particular time was teaching some of the old General's boys to play polo. I don't think to the day he died that Herbert even dreamed what an unbelievable beast the General really was.

At last it was arranged that I should meet the old tyrant and see his zoo. At the hour appointed we drove out to his, farm some miles from the city and waited near the umbrageous rain tree under which he held his audiences. Before long a host of his Andino cowboys, armed to the teeth, rode up in a cloud of dust and in the middle of the great straggling group rode the General on a beautiful horse. He held a large umbrella over his head and carried a little grandchild in front of him in the saddle. The 
cowboys all took up places on fence posts hither and yon, for Gómez was in terror of assassination. After the General had spoken to several other people, Dr. Riquena, his personal physician, came up and motioned for Herbert and me to step forward. We did. The General shook us cordially by the hand, his own being encased in thin, purplish silk gloves. It was said that he wore these and changed them frequently to make it difficult for anyone to rub poison on his fingers which he might afterwards get in his mouth. This of course is pure hearsay; nevertheless the gloves were there. When he found that I could speak Spanish, he began asking questions. Before long Hagenbeck was sent for and he and I started to make a tour of the zoo, charged to return later on and report to the General on what we had seen.

The zoo was something which I shall never forget. It was utterly unlike any other. For instance, its several enormous specimens of hippopotamus lived in a pretty little lake in a vast field where giraffes, zebras, and a host of other antelopes wandered about quite as if they were at home and in country similar to East Africa in appearance. He had truly an extraordinary collection. A few specimens stood out particularly. He had a remarkable lot of the rare spectacled bears found in the Andes of several South American states and the only bear south of Mexico. His pacaranas, which look like nothing but overgrown black beavers with stubby tails, were his most priceless zoological gems. They are the largest of the strictly terrestrial rodents and they represent the monotypic genus Dinomys.

While we were looking at the Dinomys the General walked up. Of course his animals were not labeled and 
he said to me, "I bet you don't know what those are." I replied, "My General, you have lost your bet," and proceeded to tell him. He was quite amused. But it was by sheer chance that I happened to know, for to this day we have never been able to get anything more than a skull to represent this genus in the Museum in Cambridge. The animal has a wide distribution but seems to be excessively rare throughout its entire range.

We at length drove on to Lake Valencia which I wanted to see on account of its birds. They were interesting, but as a show not up to those of Florida. We finally reached Puerto Cabello, that famous harbor which was given its name, the Port of the Hair, because it was so well protected that a ship could be moored with a thread. We found Allison in port cruising frantically up and down in the yacht's launch, passing back and forth along the waterfront holding a yellow flag in his hand. He had been in the harbor for hours and in spite of frantic signalings had been unable to get the attention of any officials to be formally received.

I went into the customhouse, for of course my baggage had to be passed out of the country with a good deal more in the way of inspection than when it came in. The customs officer was sitting at a high desk writing industriously in a ledger. I told him that I had been lunching with the General at Maracay and that he had asked Dr. Riquena to notify the port officials that we were not to be interfered with in any way. The collector of the port said that he had had no such news. I was too old a hand to be much surprised, but I was somewhat incensed when 
he said that he doubted the luncheon story. I said, "Fine, but I should hate to be in your shoes," and grabbed at his telephone. This called his bluff completely, and bidding good-bye to my host I seized my bags and threw them into Allison's launch.

I waved to Stabler, pushed my way down the steps of the quay, and jumped aboard. On the quay were a crowd of the most pitiful-looking convicts I have ever seen: loaded with chains, they were being taken out to an island prison in the harbor. After Gómez's death the prison was finally dismantled and abandoned, the frightful terrors there having been revealed to the world. We went quickly out to the launch, got aboard, hoisted the gangway, and started the engines. We had not gone far when there was a good deal of sudden activity on a small Venezuelan man-of-war anchored not far away. She whistled frantically but obviously had no steam in her boilers. Fortunately she refrained from firing on us. We felt distinctly more comfortable, however, after we had turned the point and left the mouth of the harbor.

A visit to Cartagena followed. Then came the Canal Zone and Barro Colorado Island, where more repairs to a troublesome engine gave me needed time to prepare our annual report. After this visit we went on to Cienfuegos Harbor. I disembarked for Soledad and thus ended a memorable and most delightful voyage. 

PART II

THE SEDENTARY NATURALIST 



\section{CHAPTER XI \\ Naturalists in Dispute}

TENERALLY speaking, the naturalists of today are a friendly clan not given to bickering and to reviling one another. Two generations ago they were quite different. The turmoil which followed the appearance of Darwin's Origin of Species is familiar to many, but the scientific feud which accompanied the opening up of our Western country is less well known. When the fossil fields in the badlands of the West were accessible to exploration and the Army had the Indians more or less under control, the rush to collect and describe the treasures which were uncovered by each succeeding rain as it washed down the banks of ravines makes a story almost unbelievable today.

The principal competitors were Professor Othneil Charles Marsh of Yale and Professor Edward Drinker Cope of the University of Pennsylvania. Marsh had wealth at his command, was an honorary member of forty-one scientific academies in twelve different countries. For many years he was President of the National Academy of Sciences and used the power of this office to keep Professor Cope from being elected. Not until after Marsh's death was Cope admitted to the Academy, and this despite the fact that he belonged to one of the most distinguished Quaker families in Philadelphia, was a great naturalist and a kinsman of all the various and sundry Drinkers whom we admire today. 
Both these men, wealthy, fashionable, and learned, stooped to any depths to steal a march on one another. Their rivalry was so bitter, their hatred of each other so intense, that to us the feud seems almost incredible.

Cope had an uncanny visual memory. I remember Leonhard Stejneger, late Head Curator of Biology in the U. S. National Museum, telling me that Cope stood looking over his shoulder at a curious little lizard which the old collector, John Xanthus, had sent in from Lower California. Stejneger was studying this lizard when Cope entered the room, indeed he was preparing to write out his description, for nothing like it had ever been known before. Cope glanced at the specimen for a few moments, put on his coat, walked to the telegraph office, and wired a perfectly accurate description of the beast to the American Naturalist, thus gleefully stealing the credit of the discovery for himself.

In addition to their own efforts, both Marsh and Cope employed other collectors who traveled far and wide, gathering fossils and ruthlessly destroying material which they did not have time to take up before the approach of winter so that no rival would chance to find it subsequently.

Samuel Garman was a protégé of Alexander Agassiz, who was also sent out into the field. On one trip he reached Fort Laramie just as Professor Marsh brought in a collection which was to be shipped east. As I remember it, neither Marsh nor Garman knew that Cope was in town. Since lodgings were scarce, Garman bunked in the empty station.

Late one night, after he had turned in, he heard someone stealthily enter the room. The intruder made a careful examination of the slatted crates containing Marsh's material. This went on for some time, then at last the figure 


\section{Naturalists in Dispute}

departed empty-handed. In the morning Marsh arrived. Garman described what had happened and Marsh said, "Oh, I foresaw that possibility. That was Cope. He likes to describe from skulls, and all the good skulls I got this season are in the stove." Marsh then went to the stove, opened the door, extracted a bushel or so of treasures, wrapped them, boarded the train, and went east with the cream of his catch. Marsh didn't dare keep them in his lodging, but put them for safekeeping in a place where he felt sure they would be undisturbed - as they were.

Garman himself was an extraordinary character. After such training it was no wonder he was secretive about everything. He seldom talked about himself, but, working with him as I did for many years, I picked up bits of information now and then. He had run away from home as a boy. He told me he was brought up as a Quaker. I imagine he had a German father and a Quaker mother, for the notes in all the volumes of his library acquired during his earliest years were written in German and in Gothic script. Be that as it may, he drifted west, became a professional hunter for a construction gang on the Union Pacific Railroad; he shot buffalo and, he told me, though it went against his Quaker upbringing, he shot Indians too on more than one occasion.

Reading in a paper that Louis Agassiz was to land in San Francisco at the close of the voyage of the Hassler, Garman trekked out to meet him and was on the wharf when the ship pulled in. He introduced himself and told the professor of his interest in natural history and of his ambition to be a scientist. Agassiz brought him to Cambridge where he remained the rest of his life. David Starr 
Jordan records that Garman was one of the little group who, with Professor Agassiz, with their own hands laid the floor of the barn which became the first Marine Biological Laboratory at Penikese Island on Buzzard's Bay. Garman kept the books of the Laboratory. His costume was singular: at first he wore a broad "Western" hat and a flaming red four-in-hand necktie. Later on he dressed in a curiously somber and semi-ecclesiastical suit, somewhat like that affected by the late David Belasco.

In 1873 Louis Agassiz died, and so did his daughter-inlaw, Alexander's lovely young bride. Alexander Agassiz was a distracted man and, to escape his grief, he set sail to make a hydrographical survey of Lake Titicaca in Peru. He took Garman with him and I well recall Garman's tales of the glories of the Andes. The Agassiz Museum still has the skin of a magnificent condor which Garman says sailed by him as he was perched on a high crag overlooking the lake. The bird had its regular beat and came by every so often. Garman's shotgun shells were loaded with fine shot, for he was collecting small birds. Feeling sure that the condor would be back before long, he took his penknife, cut his suspender buttons off and pushed them into the barrel of his gun, tamping them down with some of the paper he had to wrap his birds. Before long the great condor swept by again and with a quick aim Garman killed it. This was his last adventure. He returned to Cambridge and, so far as I know, never left it again.

His early experiences with the way Cope and Marsh treated one another's researches evidently soured Garman, for it was many years before I could come into his room without his spreading sheets of newspaper over the table 
where he worked. He made beautiful dissections, and became a most accomplished comparative anatomist, chiefly interested in the sharks and skates and rays. He had quarters in the basement of the Museum which could not be reached except by a grilled door. One rang a bell, there was a rustle of papers (the shades were never pulled up, so you couldn't look in the windows); after a while Garman came to the door and opened it, the grille outside meantime being fastened. After he had verified the identity of his visitor, he might let him in and be quite friendly. Just as often he was too busy, and closed the door.

I worked with Garman for many years and probably came to know him as well as anyone. I little realized what an oddity he really was until after his death when I found in a cupboard in his room a jar full of little stickers bearing his name and address which he had cut from each copy of the Nation. Another giant glass container was filled with his old rubbers. Whether this was prophetic, in view of our present shortage, or simply the pack-rat instinct, I leave to the reader to guess. Still more unsavory was another jar, at least three feet high, which contained bits of bread, the uneaten corners of the sandwiches which Garman had brought for his luncheons for years and years.

You see, my thesis is that working in a museum used to make people odd. Of course, that's not the case of my colleagues or me. As one of my daughters said of us, "You don't have to be crazy, but it certainly helps." 


\section{CHAPTER XII \\ Three Friends}

\section{I}

CANNOT remember where I first met John Phillips, but I became his devoted slave and admirer from the very first. John was everything that I was not-stunningly handsome, with a wonderful disposition, infinitely at ease. I have never known anyone who more completely satisfied every test of perfect friendship. I remember admiring him particularly for his independence of mind. For one thing, he was willing to admit that he was more inclined to ruffle his feathers with pride after shooting a New England partridge sitting than on the wing. I had felt this way for years and hunted in moccasins so as to creep about the woods as noiselessly as possible.

Once, walking down a wood road in New Hampshire, I happened to be trailing John and his wife, Eleanor, by perhaps fifty or sixty yards. I saw a partridge sitting in a birch sapling about forty yards in from the road. The bird had his neck stretched out straight up in the air and his feathers pressed down until he looked just about the size and shape of a rolling pin. I snapped my gun on him and killed him the second my eyes spied him and, to my tremendous relief, found that John heartily approved of what I had done. I do not think he would have approved had I ground-sluiced quail, but he knew, of course, that one gets a hundred chances to kill a partridge in this country on 
the wing to every chance to get one sitting, and we were both pretty good wing shots.

John Phillips had a keen and extraordinarily versatile mind. He was a learned gentleman in every sense of the word. Trained as a doctor, he knew that his heart was untrustworthy but made up his mind to continue to live as he always had, and he died in the woods while grouse shooting on Monday, November 14, 1938. His dog had pointed and his gun was cocked when he fell. He went exactly as he would have wanted to go. His family asked me to write a few lines for the Boston Transcript. I called up the editor's office and found that I had but a few moments to say what I could think of before the forms were closed. Under the stress of the deepest emotion I wrote these lines: -

Yesterday afternoon my wife and I went to see a picture taken in the Belgian Congo. It was beautifully done but, as I sat, I kept thinking to myself how different it was from John Phillips's story of his visit to the pygmies. In his story there were no fanfaronade, no hooey, no hardships, no dangers passed, and yet I saw in the picture one little man tapping his drum who, I feel quite sure, was the same one whose funny little face John and I had often laughed at when thumbing over his albums.

When I came home and unlocked the front door, my daughter Mary stood in the hall and her voice cracked as she said to me, "Dr. Phillips died this afternoon in New Hampshire while out gunning with Wayne Colby." 
In the best tradition of all our museum people, John traveled widely to collect, or for sport, but never had an adventure. He went to the Blue Nile, to Kenya, to Arabia Petraea, to Greenland and Mexico, often to the Northwest and pretty much all over the United States. He never wrote much about his travels. We all wish that he had, for, during his later years, he developed a highly characteristic and extraordinarily charming style which came only after long practice and good hard work, for John was not a natural-born writer. His essays on New England field sports, the story of the woodcock cover and the birch hillsides and swamps where our New England ruffed grouse gather, will live as long as men go gunning in the autumn.

John was eight years older than I am and I have looked up to him ever since I came to Boston as an example to be adnired but by no good fortune ever to be equaled. He was so modest, so selfless and so utterly courageous. I constantly felt - and I think many of John's friends did - that he was made of a finer clay than went into any of our make-ups.

New England did one first-rate work when she produced him and I do not believe that any country anywhere has done better. He, of all our generation, stood out as talented and versatile beyond us all. His thorough medical training brought him to the command of a field hospital of a Regular Army division during the World War. I think the only time he ever spoke sharply to me was when I once said "base hospital" instead of "field hospital." His contributions to genetics were timely and significant, for he worked in that 


\section{Three Friends}

field when it was still possible to squeeze a lot from a sponge which is now pretty dry. The four stately volumes of his Natural History of the Ducks he produced in his stride, preparing them with singularly little effort or talk, though he turned out a better and probably more lasting monograph than any of his colleagues have ever done.

Phillips has gone as he would have gone had he chosen for himself, but he leaves us the shadow of a great name and the benediction of a great friendship and all those in whose hearts he will ever live are the better for his example.

"And now the Sun had stretch'd out all the Hills, And now was dropt into the Western bay; At last he rose, and twitch'd his Mantle blue: Tomorrow to fresh Woods, and Pastures new."

Henry Bryant Bigelow has been another friend whose example has swayed me more than he, or I, for that matter, will ever realize. I met him just after I came to college and recognized him at once as a great naturalist. He was enough older than I so that he exercised a natural leadership without either of us knowing it. He loved duck shooting and used to go with me to Barbour's Hill, on the border of Virginia and North Carolina on the beach. This place then belonged to my father; it has now passed into the hands of my cousins. We had some wonderful adventures together, for the shooting in those days was memorable indeed. Henry and I shot about equally well, but as a fisherman he was infinitely more skillful than I. I envied him his journeys with Mr. Agassiz on the Albatross, 
but much more for the principal reason why Mr. Agassiz took him as a companion. For Henry is an artist who could have done far more than paint the exquisite illustrations of the jellyfishes, concerning which he is the world's authority. Henry's manual dexterity with any tool, as well as brush or pen, is in sharp contrast to my inept pair of hands. He has been a wise and sagacious counselor.

He made two journeys with Mr. Agassiz, once joining him in Ceylon, to board a small ship belonging to the British India Steam Navigation Company, which was chartered for a visit to the Maldive Islands, certainly one of the leastknown quarters of the world. In fact I have never even spoken to anyone else who has ever been there. On my wall hangs a picture of Mr. Agassiz seated beside the Sul. tan of the Maldives, one Abdul Abou Hamadudu with whom Henry carried on a correspondence for some time, The poor Sultan must have fetched up in some sort of jam with the British Raj, for the last letter Henry received said the Sultan was in exile in Cairo.

His other journey was on the old Albatross, a research vessel belonging to the United States Bureau of Fisheries but manned by the United States Navy. Mr. Agassiz arranged to use her for a number of long voyages on a basis of sharing expenses, and then sharing the collections made, with the government institutions. Henry was on the cruise known as the Eastern Tropical Pacific Expedition and it was during this voyage that he laid the foundations for the world-wide reputation which he now enjoys as an oceanographer. His definition of the effect of the Humboldt Current on the distribution of marine life brought forth the highest praise from Sir John Murray, the greatest oceanog- 


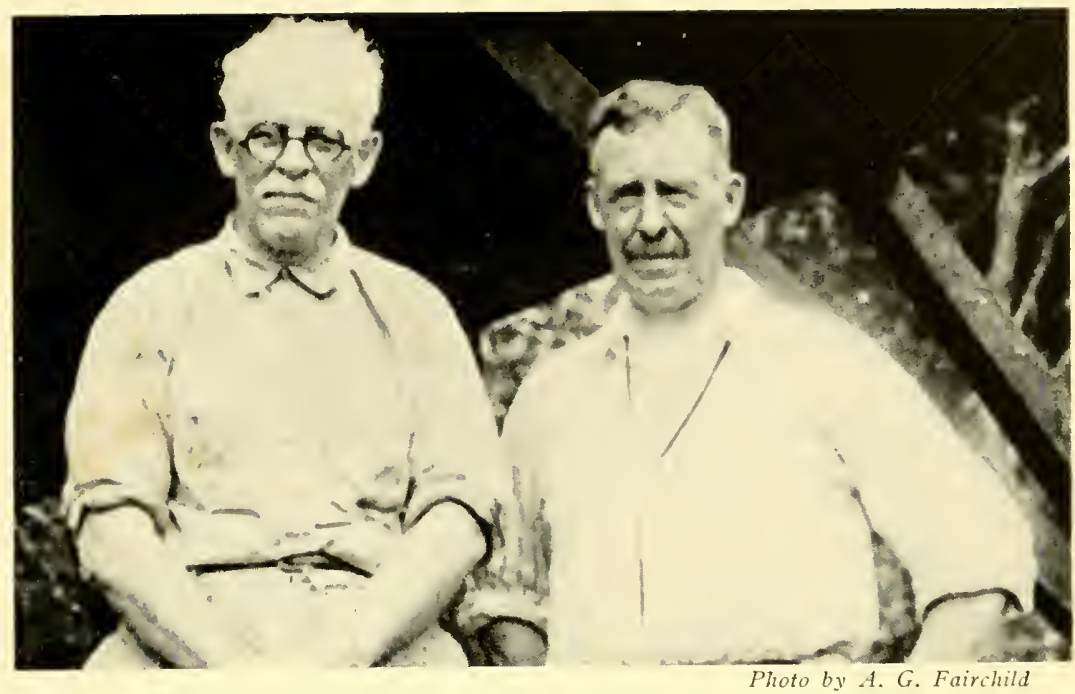

Darid Fairchild and William Morton Wheeler At Barro Colorado Island, 1924

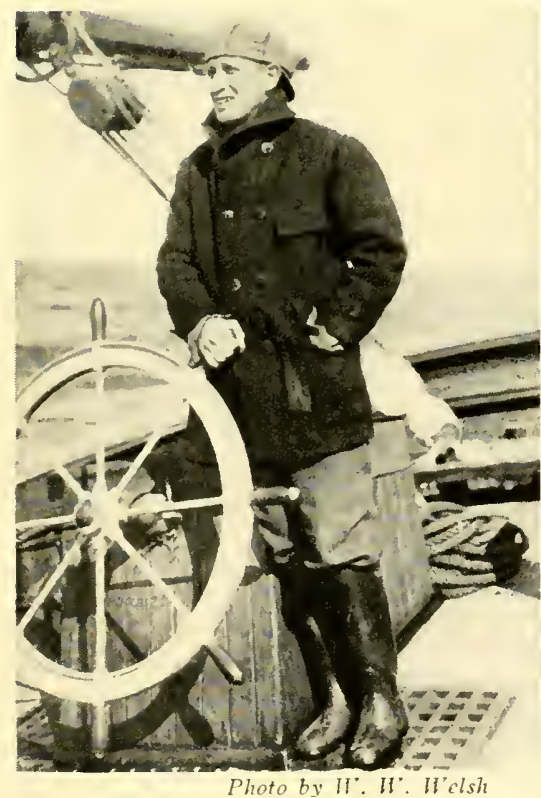

Henry B. Bigelow

Aboard the "Grampus," 1913

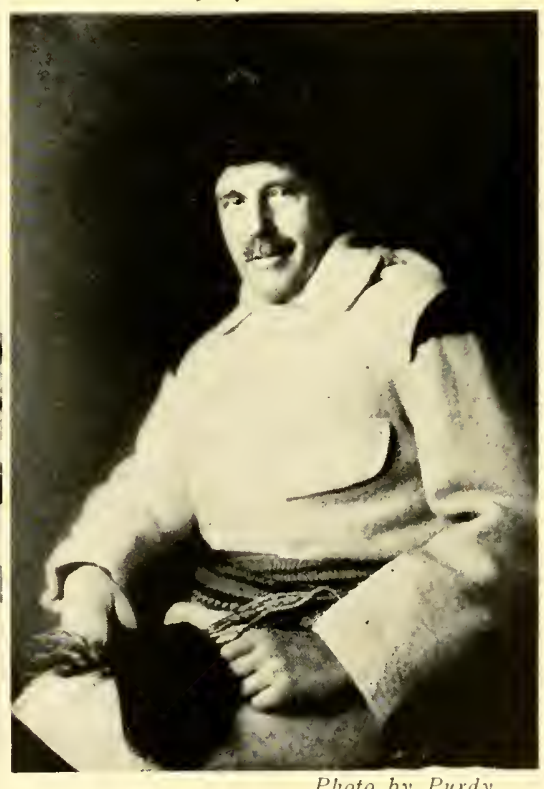

John C. Phillips 1934 

rapher of his time. Sir John told me of his opinion of Henry's work on a number of occasions.

Henry built up the Woods Hole Oceanographic Institution out of nothing. The report which he prepared showing the need for such an organization induced the Rockefeller Foundation to endow it, and the Institution is now doing admirable research for the United States Navy.

A third friend has won for himself a place quite as deep in my affections as John or Henry. This is David Fairchild. I am fortunate in that my best men friends were all handsome and David has the temperament of an angel. No more lovable human being ever lived, nor anyone who could write more delightfully charming English prose. Every sentence he writes is crammed with unbelievable grammatical errors, yet everything he writes holds one's breathless attention. His two books, Exploring for Plants and The World Was My Garden, have made him, if possible, more widely known than he was before.

Marrying Alexander Graham Bell's daughter put him in touch with all that was best in Washington. The fact that he later traveled all over the world for years on end simply meant that he left a stream of friends behind him on every continent. As Chief Agricultural Explorer in the Department of Agriculture, he has affected in some degree the life of every American. The very wheat of which our bread is made is a better wheat than was grown years ago, and David had a hand in bringing it to America. I make fun of him because he has no bump of locality, because he loves to tilt with windmills, because he would like to be a reformer and crusader, which I am not, but I am sure he 
knows in the bottom of his heart that I am his loyal and loving friend.

Every time the postman comes to the door I wonder whether, by great good fortune, he will bring me a letter from David. Here is a sample, picked at random from among hundreds that I treasure: -

The Kampong

Coconut Grove, Florida July $3,{ }^{\prime} 42$

DEAR TOM:

This is the month for the Kampong. It's the month for mangoes beginning to ripen, for white sapotes, for guanabanas, for Poincianas in full bloom, for palms in their full glory of luxuriance, for Baubinia galpinii - handsome as the "flame" Azalea - for Heliconia sp. at the swimming pool, for Cereus of various sorts, for Aechmeas and Bromeliads and native orchids and "Natal" pineapples ripening in the pineapple patch.

But last, not least by any means, it's the month for mosquitoes. If you swell up when they bite you, it's a month to avoid, just as June in the North Woods is a poison month for me who swell up and go blind when a black fly bomber strikes me.

I spent a forenoon at the Fairchild Tropical Garden a few days ago and find things are in pretty good shape. Planting is going forward, Mathews is keeping the weeds away from the young palms pretty well, and an amazing growth of palm fronds is being made. Slowly the Palmetum part comes up out of the little- 
plants-all-about stage and enters the palm-grove one where patches of shade are cast by larger leaves.

Don't let anyone try to convince you, Tom, that most young palms grow well in bright sunlight. They need plenty of dense shade at the start off.

The Bailey Palm Glade is taking form and although the stonework looks now rather glaring, a year of vines will make it look a century old. The front walls of the Garden now are nearly hidden by a mass of beautiful vines as luxuriant as they can be.

You know there has been some criticism of the fact that no signs were set up to mark the site of the Fairchild Tropical Garden. Well, now there are enough to stop any traffic and divert it. The signs are large and well made and in lots of good style. They would do honor even to the Arnold Arboretum. There are four of them forming a complete stop to traffic. And there is no suggestion whatever of their being signs to catch suckers. I am much pleased with them aside from a certain feeling of embarrassment at seeing my family name played up so prominently. "Kellogg's Sanitarium," "Kresge's Chain Stores," "Ford Cars," etc., etc. You know how I feel.

Of the human happenings on the porch too many have occurred even to outline them. Danish Commando fliers from the Burma Road three weeks by air from the fighting zone; Cabot Coville from his month in Corregidor with MacArthur, and Quezon and Sayre; callers from Cuba who describe a country house there of a wealthy Cuban family where twelve dogs dine in the dining room with a family of ten, 
all together; Dr. Bugher from Bogotá going back with thousands of hypodermic needles to inoculate the people there against yellow fever, etc.; a tea planter from Assam living on $\$ 50.00$ a month with $£ 2000$ sterling frozen in New York.

Crash!! I hear a big branch fall and Sands calls up from below to say it's an overloaded Haden mango branch. So we will bave green mango pie for dinner tonight - don't you want a slice? Loomis is in Washington but Sis and Jimmie and Marjorie are helping on the mango crop here and also cross pollinating the Pochote flowers at 9 P.M. by flashlight.

We use the fancy salts every morning and so have a different egg dish each time!

Mangoes will come along soon now. They aren't quite ripe yet.

A funny thing happened June 3oth. The censor called up and asked me, "Have you any relatives in Panama?" "Yes, indeed," I said, " a son Graham Bell and his wife and baby, and a daughter, Nancy Bell Bates." "Have you no other relatives? Do you know of any other David Fairchild?" he asked. I said, "Well, to tell you the truth, I thought when I came to the telephone that my son might have cabled me that a new baby boy had arrived and that his name was 'David Fairchild,' and that the phone call was to take the cable message." The censor laughed and hung up.

An hour or two later came the cable from Graham, addressed to me: "David arrived safely and well. Graham."

The poor censor was puzzled and thought he had 
discovered some person stepping into the Canal Zone without advising him.

It stands about $80^{\circ} \mathrm{F}$. now at night but with a fan it's not so bad. Did you ever hear of a big crab making right for you? I went barefooted with a flashlight about 3.30 last night to read the thermometer and an enormous crab started right for me. I had no other tool than my flashlight so I struck at it with that. It fought fiercely and I had the terrible feeling - "What if the flashlight goes out and leaves me there in the dark barefooted to fight this crab?" Luckily I knocked him out before the flash went out and retired behind the screen door. The thing was so sudden and so fierce and exciting that I got a big thrill from it that kept me awake until dawn. Strange how one's environment impinges on one when he least expects it! I fell over a big oak tree root below my study and busted a vein in my leg and the leg swelled up to a big size but is all right now.

That fight in the desert sands [Libya] must be the nearest approach to Hell that humans ever have experienced. And for what? Because of an insane vision of the world by a paranoiac and his fanatics.

Love to you all up there from us all here.

DAvid 


\section{CHAPTER XIII \\ Mr. Justice Holmes}

I

FIRMLY believe there is a blind spot in the eye of every man and, although I know that I shall be accused of lèse-majesté, I was never more completely convinced of this truth than with Justice Oliver Wendell Holmes. Most of his friends maintained that he was entirely aware of his own intellectual powers and their limitations, but his friends were only partially correct. He read constantly, quickly, and he had a retentive memory. But he knew of science only from hearsay, so to speak. He had a curiously definite idea about science - an utterly erroneous onewhich is one held by many laymen. He lumped together those sciences which may really be called exact with those which are much more arts.

Let me exemplify. Mathematics, physics, chemistry, that combination of biology with physics and chemistry which we call physiology, all these may theoretically become open books complete to the last word. It is theoretically possible to conceive that all of the possible questions which concern them may be answered. This is not true of, say, systematic botany or systematic zoology. Here we may record the end results, perhaps all the end results, in the formation of genera, species, varieties, and races, but we can never expect to postulate a knowledge of all the reasons which have gone into the making of each of these cate- 
gories. The motive force of evolution is beyond our ken.

This view Mr. Holmes could not or would not understand. He often spoke of the promise which science held for the cosmos of the future. He was a sincere, confirmed, and in some respects quite simple-minded atheist. He believed that the scientist, given time and painstaking research, could reasonably be expected to solve all problems. He saw no reason to personify a mystery, and it never would have occurred to him to pray to "Him to whom all hearts are open, all desires known, and from whom no secrets are hid." I have heard him explain his attitude, often in a very naïve way, on many, many occasions. I never felt like arguing the matter with him because I was usually too fascinated listening to what he had to say. His sparkling choice of words, his superb voice, and his personality held one spellbound.

I still believe that had Justice Holmes known as much about science as he knew about philosophy, ethics, logistics, or history, he would have been forced to admit that there are certain categories of facts for which science holds no key. And this is where the deist, the humble soul who makes no parade of his religious belief, feels positive that he has something quite tangible, which the atheist has not.

Justice Holmes was completely happy and satisfied but, in regard to science, he was extraordinarily trusting and uninformed. With all his learning, with all his vast and mature scholarship which gave him that superb beauty of utterance, of imagery, and of apt quotation which decorated the ornate loveliness of his literary style, Mr. Holmes still had his blind spot. 
Justice Holmes was fond of the ladies and he made no bones about it. I remember once walking with him past a war-bond poster by Howard Chandler Christy. It was pasted up on a billboard in Washington. The Justice hesitated before the extraordinarily lovely feminine figure and then remarked, "Gad, if we could only see her without those clothes!"

I came to know him well because my mother-in-law was not only a relation of his but a great favorite - she was a person of the most stunning beauty. As years passed he transferred his affection to my wife, saying to me on more than one occasion, after Cousin Fanny's death, that he loved Rosamond better than anyone in the world. He tolerated me, liked to go walking with me, and talked to me for hours at a time on innumerable occasions. In the first place we were next-door neighbors at Beverly Farms, and in the second place I represented a point of view and a vocation with which he had little familiarity. His intellectual curiosity being what it was, I think he was interested in knowing why anyone should do the odd things that I constantly did.

I often felt that it was a strange thing that Mr. Holmes was disinclined to admit the extraordinary excellence which was personified by Robert E. Lee. The mere fact that Lee was a "Rebel" damned him completely. Mrs. Theodore Roosevelt once had her secretary call up Mrs. Holmes, asking her to come to a tea which she was giving on short notice to meet General Stonewall Jackson's widow, who happened to be in Washington. Mrs. Holmes declined the invitation and gave her reason. The secretary 
protested that Mrs. Jackson was completely reconstructed. Mrs. Holmes replied, "But I'm not." And being a most completely independent being she stayed away, invitation to the White House notwithstanding.

The Justice was very frank concerning his likes and dislikes and the things of which he felt himself completely a master. He was extraordinarily sentimental. I have seen him break down and cry so that he would have to discontinue reading some of the poems about the war, which I will frankly confess I could not have read myself without acting in just the same way. For while at first sight he was austere, apparently inflexible, indeed the personification of the ideal judge, he nevertheless had a warm and tender heart. I can see him now as he sobbed unashamedly when he came immediately to call on Rosamond after our only son died on September 3, 1933.

The Justice was an inveterate correspondent. He wrote, always in longhand, rapidly and easily for hours and hours at a time. Rosamond knew that he liked a box of good New England apples in the autumn, roses at Christmas, a salmon when we went to Canada in the spring, and oranges from Grandmother's grove at Eau Gallie. Each gift brought a charming and affectionate letter, like the one he wrote on January I, 1927: -

\section{MY DEAR Rosamond:}

The first letter of this year is to wish you a Happy New Year and to thank you for the beautiful roses that were put upon my desk half an hour ago. We began to be cousins in good earnest last summer and it 
made me very happy. You and Tom are both dear to us, and thank you for this evidence that you remember me.

Ever affectionately yours,

\section{O. W. Holmes}

That was the summer we became next-door neighbors at Beverly Farms.

On January 29, 1932, he answered my wife, who had written begging him, as she often did, to put his reminiscences, particularly his war experiences, on paper. He replied: -

\section{MY DEAR ROSAMOND:}

If any magnet could draw me from the mud of silence, you would do the trick, but I should no more think of writing an autobiography than of writing an epic. I suppose you know it and that your letter is quasi-chaff. It was a delight to see you the other day. It always is. I am a pretty well preserved old cove and I still know a charmer when I see her. My love to Thomas.

Your affectionate,

\section{O. W. Holmes}

During the last few years of his life there were times when correspondence went through his secretaries, as writing became difficult for him. In January 1933, I sent him a copy of a little notice which I had privately printed after my colleague Outram Bangs's death. I thought it had a flavor which possibly might please the Justice, as he had 
heard me talk about Outram so often. His secretary (at that time Donald Hiss) replied for him as follows: -

My deAR Mr. Barbour:

The Justice asks me to say that he is sending a copy of The Speeches to you for Professor Lowes. He found that he had two copies and therefore is sending you this one, since you requested it. Also the Justice asks me to thank you for your notice concerning Mr. Outram Bangs, which impressed him very much. But he says that he notes with sorrow that you use the word gun as a verb, to wit: gunning. The Justice says that he does not feel positive about this word, but he does know that he has nursed a prejudice against it since childhood. He considers it, however, only "partial and not utter damnation." I was delighted, personally, with your use of gun, as earlier in the year I had been called to account and had stated in a plea for mitigation of the punishment that it was a term used by duck shooters rather generally and therefore should be accepted to a certain extent. But, of course, I held little hope! The Justice sends you his love and hopes to see you very soon.

I am,

$$
\text { Sincerely yours, }
$$

Donald Hiss

I playfully replied: -

Dear Mr. Hiss:

You give the Justice my love, my thanks for the book, and my most complete and vigorous scorn at 
his not liking one of my favorite verbs. If I say I am going "shooting," there is always the implied expectation that I will find something to shoot, whereas when I take my dog and go "gunning," I may shoot something but I may equally well walk a peaceful day with simply a little added weight on my shoulder. Also, praises be to God, I note that the dictionary treats the word with distinguished courtesy. What's more I like it and always have liked it and I love to use it - but I love the Justice a thousand times more. Tell him just this.

Hiss answered: "The Justice read your reply to his letter with much pleasure and amusement. His message to you concerning that dispute is, 'When he goes to Purgatory he will get rid of gunning.'

Justice Holmes was one of the greatest men I ever knew well - if not the very greatest. What made him seem the greater was the fact that he was not omniscient and that his trifling foibles and frailties accentuated his warmhearted humanity. 


\section{CHAPTER XIV Lifework}

T

LHERE are many different kinds of museums and I know little or nothing about museums of art or of history, and not so much as I should like to know about museums of archaeology and ethnology. But of museums attempting to aid public instruction or advanced instruction in biology, I think I can speak ex cathedra, for I have visited certainly a hundred of them and have worked in one pretty much all of my life. It is quite natural that I should have asked myself a thousand times, "Why bave the damn things anyway? Am I simply caring for an accumulation of junk in the final analysis, or is what I am doing serving a useful purpose?" However, when I look back on the number of intelligent questions which have come from all sorts of persons, and which I think I have answered, I feel a little more encouraged about things.

Of course, there are the economic aspects of museum service, the help we give the economic entomologist, the physician, particularly the physician in the tropics, who is up against insect-borne diseases and snails carrying intestinal parasites, and poisonous snakes, and indeed poisonous animals, running from vertebrates to jellyfishes. Some bats convey rabies and transmit trypanosomiasis, a parasitic disease in horses, and so on ad infinitum. These beasts cannot be talked about or discussed without having a name 
to call them by and that name has got to be the right name; otherwise someone reviewing the work done twenty years later interprets that work in terms of another animal and it all comes to naught.

These, however, are the purely practical aspects of the usefulness of a museum. To my way of thinking, they are utilitarian and infinitely subservient to a point of view set forth by Mr. Eliot in his essay on The Aims of Higher Education:-

The museums of a great university are crowded with objects of the most wonderful beauty - beauty of form and beauty of color, as in birds, butterflies, flowers and minerals. They teach classification, succession, transmutation, growth and evolution; but they teach also the abounding beauty and loveliness of creation.

I have often felt the stimulus of the beauty of the things which it has been my privilege to handle. Sir Henry Miers said in a report to the trustees of the Carnegie United Kingdom Trust: -

It is by means of exhibited objects to instruct, and to inspire with the desire for knowledge, children and adults alike; to stimulate not only a keener appreciation of past history and present activities but also a clearer vision of the potentialities of the future. They [and here he is speaking of museums in general] should stir the interest and excite the imagination of the ordinary visitor, and also be for the specialist and the student the fruitful field for research. 
I cannot emphasize too strongly the fact that the purpose of a museum like the one in Boston is as different from that of the one in Cambridge as chalk is from cheese. For financial reasons, the Boston Museum must limit its field to public instruction, to support such activities as the Junior Explorers, to provide decent service for publicschool classes. The Museum in Cambridge supplements university instruction in general zoology, comparative anatomy, and paleontology. It trains curators for other museums. Incidentally, without interfering with its more important activities, it provides opportunity for instruction to the public-school children of Cambridge and educational exhibits on a limited scale for persons of more mature years. It is, however, primarily a museum dedicated to investigation and to the publication of the results thereof. It deals primarily with what is called systematic zoology - taxonomy, in other words; and Mr. Charles Regan Williams in England has set forth concisely and explicitly what taxonomy is: -

The value of Systematic Zoology is generally understood, though perhaps still occasionally liable to deprecation. The first requisite in zoological work of any kind - morphological, economic, or any otheris to know what one is dealing with; before we can so much as begin on any other problem, we must know what our animals are-must have them described, named, and classified; and Systematic Zoology, which does this, is thus the bed-rock on which all other zoological research ultimately rests. Such work stands for all time; the first adeqquate description of a new 
animal is something which can never be duplicated, never repeated; it is there, once for all, as something to be appealed to, something that cannot, by the rules under which the systematist works, be superseded. It may seem to be of little interest at the moment; it may not be recalled for years; but it will be required, and will come into its own when much work in other branches has become obsolete through change of fashion or improved technique, or has been shown to be useless for any further advance.

One year when I was feeling homiletical I decided to head my Annual Report with a text and I chose this line: "A satisfied curator, like a finished museum, is damned and done for." That is exactly where the museum is like the library. It has got to keep growing; otherwise its significance ceases. One gets more books and the other gets more critters. There is no great difference between the two.

Our science museums at Cambridge form such a patchwork quilt that a great deal of confusion exists concerning the organization. The Museum of Comparative Zoology, built from money appropriated by the Massachusetts Legislature and that donated by friends of Professor Agassiz, is housed in a building which was commenced in 1859 . A gift of Mr. Francis Calley Gray settled it with an unchangeable name and a cumbersome one, too - the $\mathrm{Mu}$ seum of Comparative Zoology at Harvard College. Then in $1876 \mathrm{Mr}$. George Peabody chose Cambridge, along with Salem and New Haven, for the establishment of museums of several sorts. The one in Cambridge became the Peabody 
Museum of Archaeology and Ethnology. These two institutions were originally independent, affiliated with Harvard College but not controlled by it, having their own boards of trustees, and hence autonomous. Later they conveyed their possessions to the College, each forever to have a self-perpetuating governing board, confirmed by the governing boards of Harvard College, and each having the rights and prerogatives of a faculty in the University. These two museums are governed in this way to this day. Years passed and other buildings to house Botanical, Mineralogical, and Geological Museums were constructed, and finally the whole formed one continuous structure.

The three museums last mentioned are not governed by a faculty. The general control of the building, the distribution of space therein, and matters affecting more than one section, such as repairs, hours of opening and closing, etc., etc., make it desirable to have one official responsible for such matters, so that while each Museum has its individual director, I have the title of Director of the University Museum as well as of the Museum of Comparative Zoology. This situation might conceivably lead to friction. As a matter of fact, it leads to nothing but the pleasantest and most friendly associations. The Museum of Comparative Zoology is widely and very happily known as the Agassiz Museum; the others have no occasion to use other than their own official styles. As with so many of the institutions connected with Harvard University, which, like Topsy, just growed, the complicated setup, which might be expected to be cumbrous and unhandy, works extremely well. 
One of the pleasantest features of life in the Museum grew entirely by chance. During one long spell of bad weather Henry Bigelow and I began to bring our lunches to the Museum and ate together in my back office. Then it occurred to me that we had in Gilbert, working here in the Museum at odd tasks, a most courtly old-fashioned colored servant who, as he put it himself, had been left to the Museum with Mr. Brewster's collection of birds. We installed an electric stove, proper sink and electric refrigerator, and screened these objects away in a corner of my office, which is a large one, so that they do not obtrude.

William Morton Wheeler joined our group and in time the Eateria became quite an institution. As long as Mr. Lowell was President of the University he not only called up frequently and said that he was coming to lunch but brought guests who he thought would be interested in learning about the Museum under entirely informal circumstances. I remember one day he brought Sir Frederic Kenyon of the British Museum and Sir Henry Miers with him and they paid us a most enjoyable visit. My friend William Claflin, now the Treasurer of the University and its most useful officer, has taken up this same practice to our great advantage and joy.

Rosamond provided a lunchbook, a beautifully bound parchment volume. Each person who lunches in the Eateria for the first time signs his name in full, thereafter only his initials. From September 2, I930, to September I8, I 942 , there have been over 20,800 signatures in this book. We have kept a separate book for distinguished visitors in which there are about 300 names for the same period of time. A casual examination shows that these visitors have 
come from Honduras, Canal Zone, Cuba, Norway, Italy, Panama, England, British Columbia, Ontario, Siam, Belgium, Holland, New South Wales, Germany, Trinidad (B.W.I.), China, Sweden, Japan, Brazil, Federated Malay States, France, Transvaal, Cape Colony (South Africa), Korea, Denmark, Scotland, West Australia, Philippine Islands, Colombia, Venezuela, British North Borneo, and Bermuda, but without checking through carefully I should say there had been more visitors from Holland than from any other foreign state. These books have proved unexpectedly useful on many occasions. When was so-and-so here last? Was I in Cambridge on May Iо, 1938? On dozens of occasions they have solved problems which loomed big at the moment.

The luncheons provided opportunity to ask members of the staff in for informal discussions and took the place of formal and rather stilted staff meetings. I find, to my surprise, that the Eateria has acquired a considerable fame and that scientific visitors to the Museum look forward to an invitation with real anticipation. It has been, of course, a bit of trouble at times but it has certainly served a most useful purpose. The women on our staff have been courteous and considerate in helping to serve and have made themselves generally useful; I know they have enjoyed the institution as much as the rest of us.

On January 7, 1942, poor Gilbert died and the Eateria has been maintained on a rather reduced basis ever since. But as long as my colleagues live they will remember his beautifully cooked venison and ducks after my shooting excursions. On state occasions we had terrapin prepared at the Somerset Club in town and brought out by motor. 
I have tanks in the basement where terrapins and turtles may be kept against the visit of some distinguished visitor.

David Fairchild has provided innumerable tropical fruits: white sapotes, aegles, canistels, mangoes, and many others, and a grower near Homestead, Florida, who has a particularly fine strain of papayas, has supplied these frequently.

Thanks to Wilson Popenoe, a disciple of David's now in Guatemala, we have had mangosteens. The Department of Agriculture once put a stop to their importation on the ground that they were hosts of a pernicious fruit fly. I knew that this was obvious nonsense and now, after long argument with the Department and after much experimentation, we have permits to import mangosteens and will eat them frequently, I hope, when the war is over.

I only wish that we could look ahead fifty years and see the mangosteen, queen of all tropical fruit, abundant in the Boston market. The United Fruit Company has a big grove of bearing trees at Lancetilla, in Honduras, and can easily plant more if the demand makes it worth while. The American people, however, as David Fairchild has long ago found out, are slow to change their feeding habits. Any number of excellent fruits and vegetables from all over the world have been brought to America, propagated for a short time, and then allowed to die out. I cite for example the Dasheen, which is much better than any sweet potato, the Udo, and the giant radish of Japan.

When I became Director of the Agassiz Museum, I was highly dissatisfied with the situation which I found awaiting me. Luckily, at that time I had the means to make 
changes which permitted a great expansion of our research activities. The Rockefeller Foundation had provided money for a new biological building, which took most of the old laboratories out of the Museum where they had been for years, but the space so vacated was still not enough.

I had long had the idea that we exhibited many more objects than there was need to show to our rather limited public, and I felt that by condensing our exhibits we could eliminate obsolete and badly prepared material and at the same time gain space for expansion of the research collections. This I did by flooring over the galleries in nine rooms and rearranging all of the exhibitions on the third floor of the building, with the exception of our paleontological specimens. This scheme has worked out very satisfactorily. Our research collections, which are now expanded, well-arranged, and quite accessible, are as much a credit to the University as is its great Library. Of course, I can take only small credit for this. It was a labor of love for many. In 1926 electric lights were installed throughout the building (there had only been gas before!) and they and an electric elevator improved the working conditions.

Professor Louis Agassiz designed the standard tray which we have used throughout the Museum except in the Departments of Birds and Mammals, where we have received many good storage cases which came to us with the Brewster, Thayer, Bent, Kennard, and Batchelder collections. Since birds are so different in size, our arrangement in this department is more or less haphazard. The same applies to the mammals except that with these we tan 
the hides of the larger forms and hang them up on rods in a large room which we keep sterilized against moths and other pests. But generally speaking, standard trays are used for fossils, alcoholic material, and all of the myriad types of material which are gathered in the Museum primarily to aid investigators and not to instruct the public.

The trays measure $18 \times 271 \frac{1}{2} \times 3 \frac{1}{2}$ inches, except those in the Mollusks Department, where they use a good many thousand. Theirs are only an inch deep on account of the small size of most of the material involved. These trays are contained in tall, narrow, glass-door cupboards, placed side by side, each containing twenty runners spaced so that the trays slide in and out. For very heavy objects we simply put the tray in upside down and thus it becomes a shelf. Where tall jars of fish or reptiles are stored, we have to use a tray to each four or five or six spaces. Of course no system is universally convenient, but our trays, now that we use galvanized-iron runs to support them, slide in and out quite easily even when loaded with very heavy material. We use about 500 new trays a year and estimate that at the present time there are 50,000 in use in the building.

It is idle to speculate on the number of specimens, for it would be sheer guesswork. Mr. Nathan Banks, for instance, estimates that there are three and a half million insects in the collection and knows that there are at least 30,000 types - that is, specimens from which new species have been described. This number has been definitely located; no doubt there are several hundred more in the collection not as yet found. Our insects are gradually all being worked into standard, glass-topped, airtight trays 


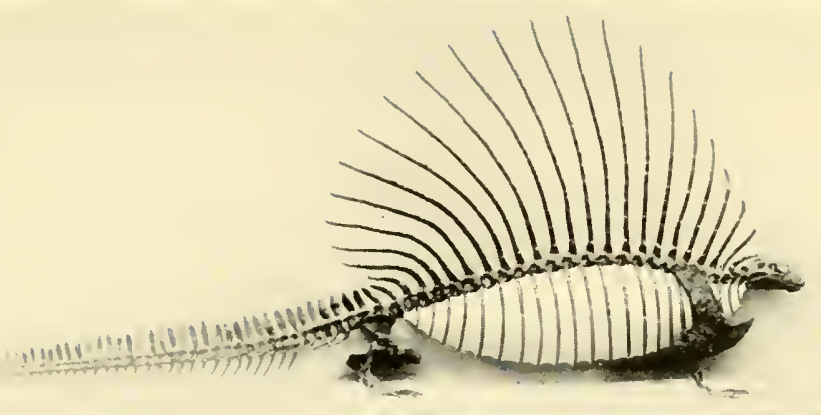

A sailback lizard, Edaphosaurus

Almost six feet long, from the Red Beds of Texas. The only one with perfect skull and all skeleton from a single indiridual

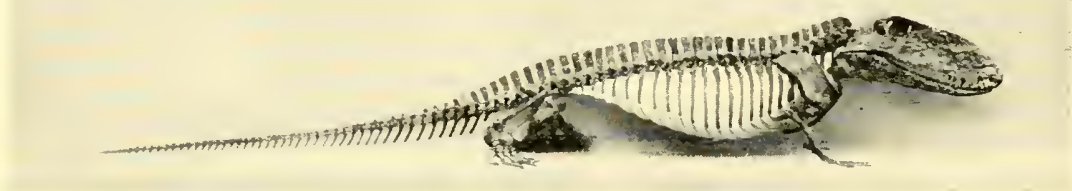

Unique mount of Ophiacodon

About four feet long, from the Red Beds of Texas. Laid down abont one hundred and eighty million years ago

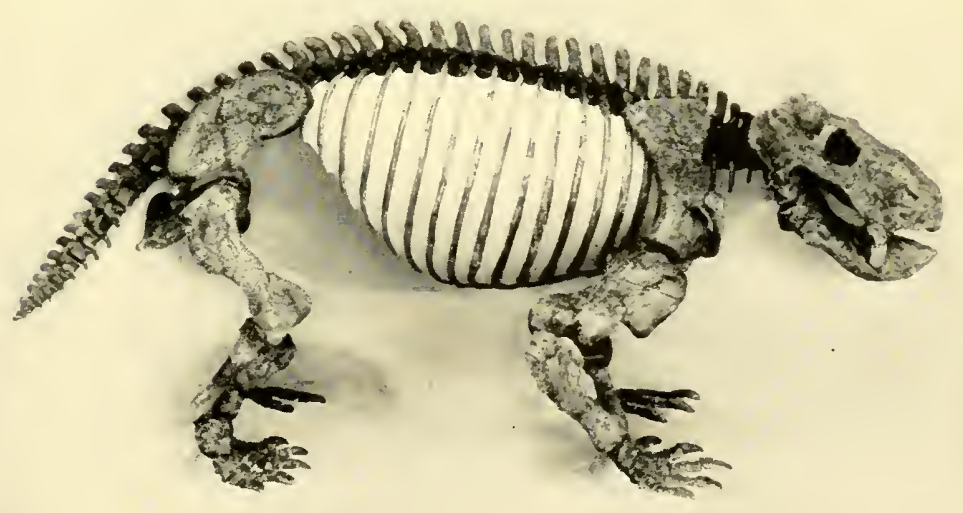

Photos by G. Melson

Unique type of Dynodontosanus olizeroi Romer from southern Brazil

Three of George Nelson's finest fossil reptiles 

I $5 \times$ i 8 inches, of which we have about 5000. Many, many insects, however, are still in various other types of cork-bottomed boxes, since our trays are rather expensive and we cannot buy them in sufficient numbers.

In view of their fragile nature, and contrary to our practice with all other groups of animals, we are inclined to mount our vertebrate fossils and put them on public exhibition. Our Chief Preparator, Mr. George Nelson, is unexcelled in his ability to make graceful and lifelike mountings and restore missing parts with perfect accuracy. Of course there are many fossils where our material is too incomplete to treat in this way.

In all other groups, types are preserved for the use of investigators and are not placed on exhibition. A recent count shows that of reptiles and amphibians we have typical material of 2173 named forms. 


\section{CHAPTER XV \\ The Glory Hole}

\section{$\mathrm{T}$}

HE MAN in the street has always been inclined to look down his nose at museum curators, and for as long as I have been one of them I have been pondering the reason. I think I have it. The average man doesn't like a miser and, one way or another, the curator cannot help appearing miserly. When I first took charge of the Agassiz Museum, I found one big glass jar filled with chicken heads, another with burned matches, another with old rubbers. The chicken heads were potential material for dissection, and the fact that a dollar's worth of heads filled a twenty-dollar jar never occurred to the man who ate those chickens, who was no other than Louis Agassiz himself.

The Museum at one time housed an unbelievable number of strange odds and ends accumulated through the years and saved because the old-time museum man thought it was a sin to throw anything out. I have been accused of erring in this manner myself. It is true that if you look at a thing long enough you lose perspective. Any object, no matter how revolting and loathsome, seen sufficiently often, blunts the senses, and one becomes disinclined to the effort nccessary to destroy it or get rid of it.

Pride of possession is a curious attribute of mankind. This was brought sharply to my mind recently when it occurred 


\section{The Glory Hole}

to me to ask myself, "Why didn't Mrs. Chase give the Peabody Museum her gallstones?" Many other people had, for there were a pint or more of miscellaneous gallstones in the Peabody Museum in Salem, curiously enough in the case with an old reindeer. But these were donated gallstones; it was only Mrs. Chase's that were on loan. The answer is, Mrs. Chase's gallstones were larger than any others in the whole place and she obviously just couldn't bear to part with them permanently. I bethought me, Has this situation ever occurred before? And then I remembered that not long ago I was reading the last Annual Report of the Curator of the Museum of the Royal College of Surgeons in London. This venerable institution, containing much material that was priceless indeed, suffered a direct hit from a German bomb. It was almost completely destroyed, and the story of the catastrophe was told, sadly and meticulously, by its distinguished curator. But if our friend in the street were to read this report he might be inclined to laugh heretically at the cool and unemotional statement that along with the many terrific losses suffered by that venerable institution were listed the facts that the jar containing Napoleon's bowels was cracked and that the rib of Robert the Bruce was broken.

I have found myself justifying the preservation of objects which were inherently unpleasing to the eye by saying, "That illustrates the taxidermy of a hundred years ago." Or the preservation of a codfish pickled in alcohol by saying, "Someone may want to dissect that fish sometime," forgetting that fresh cod, infinitely preferable for dissection, are plentiful in the Boston area. And so it goes. The more I think of it, the more I believe that the average 
man is entirely entitled to his opinion and the average curator is a queer fish.

Now granted that the curator is a queer fish, is he a rare fish? I fear me the answer today is nay. My friend Alexander Wetmore, Director of the United States National Museum, in an address at the opening of the Dyche Museum at the University of Kansas, remarked, "There are today throughout the world more than seven thousand museums, of which more than a thousand are in the United States." Every museum has at least one curator, and the breed came into being, no doubt, back in the days when the "Repositerry of Curiosity," the Anlage of our University Museum here at Harvard, was visited by Francis Goelet on the twenty-fifth of October 1750. Unfortunately, Mr. Goelet does not tell us how old the museum was at that date. He does, however, tell us that its treasures included "horns and bones, fishes' skins and other objects, and a piece of tanned Negro hide." 1

Professor John Winthrop, Hollis Professor of Mathematics and Natural Philosophy, evidently had started even at this early date to make what we call a "Glory Hole." I have had some interesting experiences cleaning out "Glory Holes" in Cambridge, Boston, and Salem. Only a few months ago I opened a parcel in Salem, the wrapping paper of which was superscribed, "Please do not disturb these shells. Caleb Cooke, February i 857." This behest had been scrupulously obeyed for eighty-five years and six months. The parcel proved to be pure gold, for the shells were

${ }^{1}$ It's a pity this burned. Wendell Phillips could have waved it instead of the bloody shirt. 
collected from one of our New England rivers in which today it would be impossible to collect a single living thing, so polluted have its waters become. I hold in my hand a little vial in which is a label saying, "This vial contains two feathers of a large penguin." One wonders why these two feathers out of the tens of thousands which that penguin carried were singled out for preservation.

The only old museum I ever saw where, so far as I could see, there was no Glory Hole was the museum in Charleston, South Carolina. This venerable institution, founded in 1773 , has had plenty of time to accumulate one, but the gay and carefree cavaliers of the South were willing to throw things away even when they became museum curators, while the penny-pinching men of the New England states fairly reveled in the making of Glory Holes. Certainly nothing equaling the collections of zoological atrocities once preserved in Boston, Salem, and Cambridge has ever been known in America, and probably but seldom in Europe. I remember one of my colleagues, now passed to his reward, pointing regularly to a certain cask and saying, "That's filled with the pickled heads of Chinese." Well, it was. They were garnered on the beach at San Francisco years ago after a battle, by Thomas G. Carey, no less. Now after some seventy years these heads, boiled out and the skulls bleached and cleaned, serve a useful purpose: Hooton of Harvard uses them in teaching physical anthropology.

Alexander Agassiz collected but one living spirula, a little squidlike mollusk whose dried shells may be found along the beaches of the tropics in countless thousands. The living spirula carried an important message, for its shell was like certain fossil shells of ages ago and gave us a clew 
to what the soft parts of those fossil animals were like. That spirula disappeared about forty-five years ago from the very desk at which I now sit writing these lines and it has never been seen from that day to this.

Mr. Alexander Agassiz always said that Professor E. D. Cope was the greatest thief in the world, for the reason that he stole the largest object ever stolen. The story ran something like this: Captain Atwood of Provincetown, who did the Museum many good turns, once notified Mr. Agassiz that a strange whale had drifted ashore on the Outer Cape. Mr. Agassiz asked J. A. Allen and some students to go down and rough out the skeleton. This they did, and laid out the partially cleaned bones on a flatcar. They little dreamed that Dr. Cope from Philadelphia also had a scout on the Outer Cape, and Cope was a canny man. He went to Provincetown, hired a room in a farmhouse, where he could watch proceedings, and waited until the Cambridge crew went home. Then he greased the palm of the station agent to the end that a Philadelphia waybill instead of a Cambridge waybill was affixed to the flatcar and the whale ended up as the type of a new species which Mr. Cope described, its skeleton still being preserved at the Academy of Natural Sciences in Philadelphia. So the story runs, and I have often heard it told in the past.

I can hear the reader mildly say, "Why on earth does anyone want to be a museum curator?" This question, however, I can answer bravely and with positive assurance. To one who has by inheritance or training acquired the pack-rat instinct it is the most exciting calling in the whole world. For who, having a spark of imagination, 
could fail to be thrilled to hold in his hand our specimen of Drepanis pacifica? This was the bird from which the feathers were taken to make the royal robe of Kamehameha the Great. The bird is extinct and our specimen was collected by Bloxam, who sailed on the Blond. It is, moreover, the cotype of a species. Any naturalist will know what I mean.

Edward S. Morse wrote an article for the Atlantic Montbly in July 1893 , entitled "If Public Libraries Why Not Public Museums." I think Morse was entirely wrong in the type of museum which he outlined as being instructive to the public. Morse's all-consuming intellectual curiosity led him to believe that all of us were similarly endowed, as of course we are not. Bits of desiccated slime in a row of bottles carefully labeled captured Morse's interest just as rows of rock samples, all looking more or less alike, enabled him to point with pride to the fact that this exhibit included a piece of every sort of rock found in Essex County. This sort of material has no value for purposes of public instruction; nothing has except that which is inherently attractive.

The Mineralogical Hall in the University Museum in Cambridge contains a vast number of objects of the most extreme beauty and rarity, yet not one person in a thousand who comes to see the glass flowers in an adjoining hall steps across the threshold to look at the minerals. This was even more conspicuously the case in the museum in Salem, where the minerals were relatively inaccessible and really only displayed for the instruction of public-school classes, and the number of visits made by such classes had 
dwindled to one a year and that class only looked at about half a dozen minerals. The glass models of plants in Cambridge and the equally beautiful botanical models in the Field Museum in Chicago interest and attract the public. Samples of wood and dried foliage have absolutely no value for exhibition.

This is how I came to think up a new kind of museum. The trustees of the Peabody Museum in Salem voted to restore East India Hall to its original monumental simplicity and to display here figureheads of ships and other objects that are best seen from a distance. The Hall for years had been filled with a jittery miscellany of zoological objects. There was a good representation of the fauna of Essex County, specimens excellently prepared. All else was a miscellaneous accumulation, acquired through the years from sea captains and others, of specimens which varied in quality from the utterly revolting to a few really fine things. It was easy to dispose of the repulsive material. Some of it had scientific value and the rest of it, when tossed out of a second-story window into the back yard on Charter Street in Salem, was fought for by a swarm of urchins, who carried the critters off in triumph. The police, at first unbelieving and suspecting theft, soon became acquiescent.

The question was what to do with the few good things which did not illustrate the zoology of Essex County. These naturally presented a dilemma. I proposed discarding them all. Then one day I chanced to lunch with Gus Loring and Stephen W. Phillips, men of original mind and deep learning, who had an honest sentimental feeling for some of the objects I proposed to discard. It was quite ob- 
vious that I could not proceed without seriously wounding feelings. I suddenly thought, "See if we can't make a human-interest story out of each one; display the object with its relation to man." A sort of rough classification gradually grew on me. There was a good skylark, and a good wandering albatross. Get a nightingale and set up a display. Label it "These birds have inspired great poetry." Use pictures of the poets, facsimiles of the poems, and some of the most superb verses in boldly typed labels.

What do domesticated animals teach us beside carving at table? Domestic fowl and the pigeon have been extraordinarily plastic in man's hands. Think of the contrast between a Shanghai rooster and a Seabright bantam. The Shanghai and the Langshan are the largest of the so-called Asiatic breeds of fowl, enormous creatures standing over two feet high. The breeds are now out of fashion and almost extinct. Luckily the Museum had some really historic fowls. Here was the rooster brought back over a hundred years ago, the progenitor of the stock which gave rise to the Rhode Island Red. And I found a wild jungle fowl which could be spared from the collections in Cambridge. With the help of my neighbor Harry McKean, I soon had plans for this exhibit well under way.

Various species of jungle fowl, which look exactly like small game chickens, are found all over southeastern Asia. When you are living in the country where they occur, you seldom see them, but their crowing at morning and evening sometimes becomes a positive nuisance. Now, conversely, although there is no reason to believe that the Aztecs did not hold the turkey in domestication for as long a time as 
any of the peoples of Asia had the fowl, the turkey has not proved plastic at all. Cortez sent domesticated birds which he found in Mexico back to Europe. From there they spread all over the world. They came to New England, and to this day domesticated turkeys, most of them, are hard to tell from wild birds. A few varieties have been produced, but only by the chance dropping out of elements of the normal pigmentation of the bird's plumage. In the reddish-colored turkeys, the black or the dilute black pigment - the gray - has gone and the red element alone remains. In the white turkeys all pigmentation has disappeared; albino races are always easy to produce in domestication. White rats and mice and guinea pigs come to mind, as well as leghorn fowl and fantail pigeons.

I visualized an exhibit around William Endicott's magnificent bull bison, not using the animal as a zoological object, a member of the Bovidae, but as a creature which provided food, shelter, sport, and even an object of worship to many tribes of Indians. And here illustrative material is abundant and spectacular.

The Museum had a first-class ostrich, given it some years ago by Mrs. Stephen Phillips - an ostrich far too good to throw away. By good fortune, I had a sample of dried ostrich meat, one of the various kinds of "biltong" carried by the Boers as rations when at war or on trek. An ostrich feather fan, an old-time bonnet, and headdresses of the Nandi Masai all proved obtainable.

Think what a story you can build about the giant tortoise of the Galápagos. The old whalcrs called them turpin. For generations all of the ships that chanced to be near the Galápagos Islands, about six hundred miles southwestward 
of Panama, went ashore turtling. The crews carried the beasts down to the beach, boated them to the ships, and piled them up in their empty holds. Here, being the strange creatures that they are, they survived for months without food or water. When scurvy appeared the turtles were butchered. The flesh was savory even when poorly prepared. There was enough fat in each one to shorten a mess of "duff," and the water in their bladders was cool and clear. I have seen a compilation made from about thirty whalers' logs which shows that they carried off more than eleven thousand of these animals. Once they occurred in countless multitudes on no fewer than nine of the islands. Seventeen zoological species of turtles have been described. But this is not the point which we want the magnificent specimen at Salem to illustrate - rather, what turtles like this meant to seamen from the time of Dampier down to about 1867 , when petroleum knocked out whale oil. Probably no less than half a million turpin were carried away, and now all the races of the creatures are rare or extinct.

Captain Phillips brought back from Fiji an enormous giant clam. The superb pair of matched valves are at least three feet long and weigh over a hundred pounds each. But I don't want this to be a malacological specimen rather, the terror of the pearl diver. For if a diver inadvertently thrust a hand or a foot into one of these gaping shells as it yawned open, the instant reaction was for the animal to close up, like any other clam, and the death of the diver ensued.

These giant clams were undoubtedly eaten, the meat being chopped fine and stewed. No doubt it was as good 
as conch, most delectable of all sea viands, unfortunately unprocurable in New England. What a dramatic underwater scene could be depicted with modern methods of creating illusions! Mold a lovely Polynesian maiden vested only with a net reticule of pearl shells tied to her waist and struggling for release from the clutch of this giant mollusk. I fear, however, such pageantry is beyond our means - and might shock Salem, anyhow.

It is probable that all of the various races of domestic duck are derived from the wild mallard, and where man first began to breed ducks for food is doubtful. It was probably in China. Anyone who has traveled into the interior of China, say up the Si-kiang River from Canton to Wuchow, will recall the floating duck farms. These great arks built on rafts move about from place to place, a gangplank is let down, and the ducks scuttle overboard and dip and dive and feed. At evening the proprietor of the establishment stands by with a bamboo wand and beats a gong and the ducks rush up the gangway, for they know from bitter experience that the last few ducks will be assiduously whacked with the bamboo just for being last.

The people in Bali have had the duck for years. The characteristic race is a white one with a large fluffy topknot, and the Balinese positively assure us that unless a bunch of cotton wool on top of a twig is put before the setting duck where she must observe it constantly, the young will not be bedecked with the much admired pompon of feathers on their heads. And though unquestionably man has played with the duck for a long time, no such enormous variety of named races has been produced 


\section{The Glory Hole}

as in the case of the fowl. The Muscovy duck is far distantly related to all the rest of its kin. This bird is found in a wild state through the tropical lowlands of Central and South America. By this I mean, of course, the forested areas. It was domesticated in Mexico, and possibly by other Indian tribes than the Aztecs. When it was brought to Europe, the tradition of its origin was apparently lost, but just why it should have been considered to be of Muscovite origin I can't remember, although I have been told. Except for albino and pied individuals, most of the Muscovy ducks are essentially the same as their wild ancestors. This is also true of the guinea hens which came to America on the slave ships from West Africa. As everybody knows, these can hardly be called domesticated. They have a tendency to run wild, and indeed in many localities in Haiti and Cuba they afford good sport with a shotgun, being strong, fast flyers.

Look at the pigeons on Boston Common and you will be struck by the fact that the vast majority of them are essentially like the blue rock dove, which is their wild ancestor. Man has produced an extraordinary number of bizarre and curious types of pigeon, but let them become feral, as they have in Boston or Venice, and they revert to the ancestral type, at least in a vast majority of cases. And the accidental additions which come from escaped fancy pigeons are soon bred out and absorbed into the essentially blue rock mass of the population. But I don't want to crowd our museum at Salem to where it appears to overstress the exhibition of domesticated animals. This aspect has been treated elsewhere. There is a wonderful collection of all sorts of domesticated types at the British 
Museum of Natural History in London, of dogs at Yale, and a fair synoptic collection in Cambridge.

A good many dyed plumes of birds of paradise seized in the Customhouse and turned over to the Peabody $\mathrm{Mu}$ seum for exhibition recalls the trade in birds of paradise. When the Dutch and Portuguese first arrived in the Moluccas, they found some of the Malay sultans receiving dried skins of birds of paradise as tribute from Papuan tribes of savages who owed them suzerainty. These skins were legless, and the notion grew that the birds spent their lives flying in the air and admiring the sun. During the last years of the last century and the first decade of this the number of birds of paradise which were garnered from the western part of New Guinea and the Aru Islands was stupendous. Queen Wilhelmina stopped the slaughter some years ago. But birds of paradise were still abundant, even considering the enormous numbers killed for trade, because the females were so inconspicuous and so utterly unlike the males that they were never disturbed and all the species are highly polygamous.

And so, to my great surprise, I find myself at last engaged in building up an entirely new type of museum. There will be many objects displayed beside the ones which I have indicated. I believe that with thoughtful labeling some zoology, some history, some folklore, and some poetry may be taught in a very attractive way. And I wish we could find a good name for our innovation. I can think only of "Museum of Ethnozoology," which sounds utterly loathsome. 


\section{CHAPTER XVI \\ Those Who Help}

Jus

UST as I have had great good fortune in the support given me by my colleagues in the Museum, so I have been aided in many unexpected ways by natives of all sorts in the field. When Rosamond and I landed in Singapore, we had a letter of introduction from Dr. George Lincoln Goodale of Harvard to Dr. William H. Ridley, Director of the Botanic Garden. Ridley was very kind and friendly and helped us to find $\mathrm{Ah}$ Woo, a tall and stately Chinese boy who had been a mess servant at the military barracks at Tanglin. Ah Woo's queue was a joy to behold. Long and thick and black as a raven's wing, pieced out with a sort of a whiplash of red silk, it extended to his heels. When he was at work it was cunningly coiled on top of his head, to be pushed off to a hanging position if one of us approached him, because to speak to a superior with one's queue coiled up was extremely impolite.

Ah Woo traveled with us and only left us to return home when we left Peking for Japan. He became a superb butterfly collector and was perfectly faithful and loyal, although he never really liked to take orders from my wife. He was so loyal that it was very dangerous to admire anything in the museum at Buitenzorg, because the object was likely to be missing in the museum and to turn up presently in our lodgings. He was a slightly bloodthirsty rascal and if there was a tree kangaroo or some other animal 
to be put to death, that its skin and skeleton might be preserved, Ah Woo always begged for the chance to perform.

He nearly got us into trouble one day at some small town in New Guinea, where one of the natives had just died. We of course knew nothing about this, our interest being centered in some carved wooden drums which we bought for the Peabody Museum. Getting into one of the big outrigger canoes to carry the objects out to our ship, Ah Woo began a joyous tattoo. Everything changed in the flashing of an eye. Angry Papuans swarmed from every house, and it was not long before we learned that you must not beat drums in the hearing of their dead. Souls might be called back from their wanderings.

Indit and Bandoung came to us through the good offices of Dr. Treub. They were mild, gentle, friendly Javanese. They had been naturalists' assistants on board the Dutch exploring ship Siboga and literally knew almost every nook and cranny of the Indies. They made very passable bird and mammal skins, although we were in such a rush collecting everything - reptiles, amphibians, insects, and marine invertebrates - that they never had a chance to do their best work. They were patient beyond belief, and when I left Java one of them wrote me a most charming and touching letter in Malay, in the Dutch transliteration, perfectly spelled and like copperplate. These two "boys" were nature's gentlemen.

As I look back over the many years when I used to go bug hunting, an innumerable pageant of kindly companions passes before my eyes. I think particularly of Juicio and Churima. These were probably not their right names, 


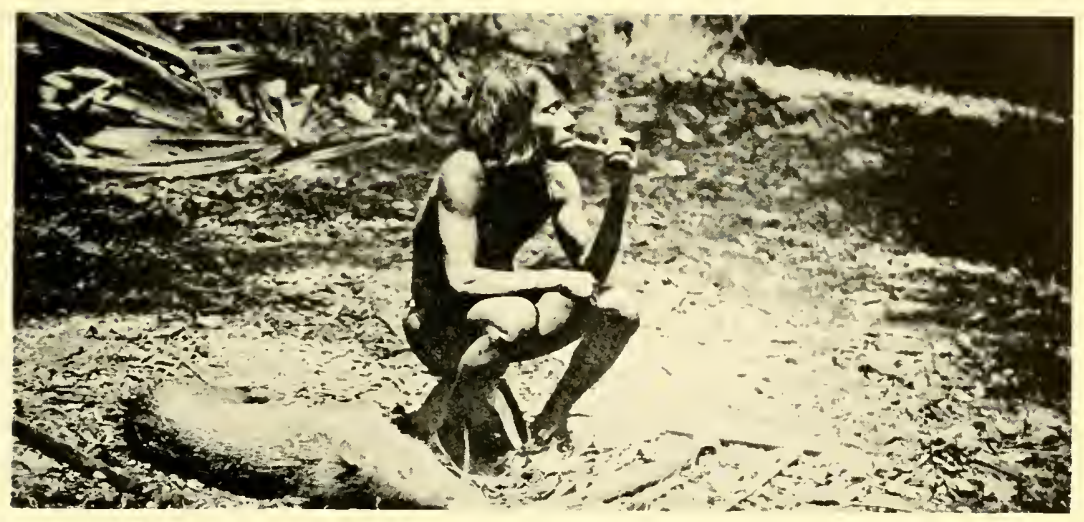

The Hunter home from the kill. Churima rests after bringing in a peccary to camp

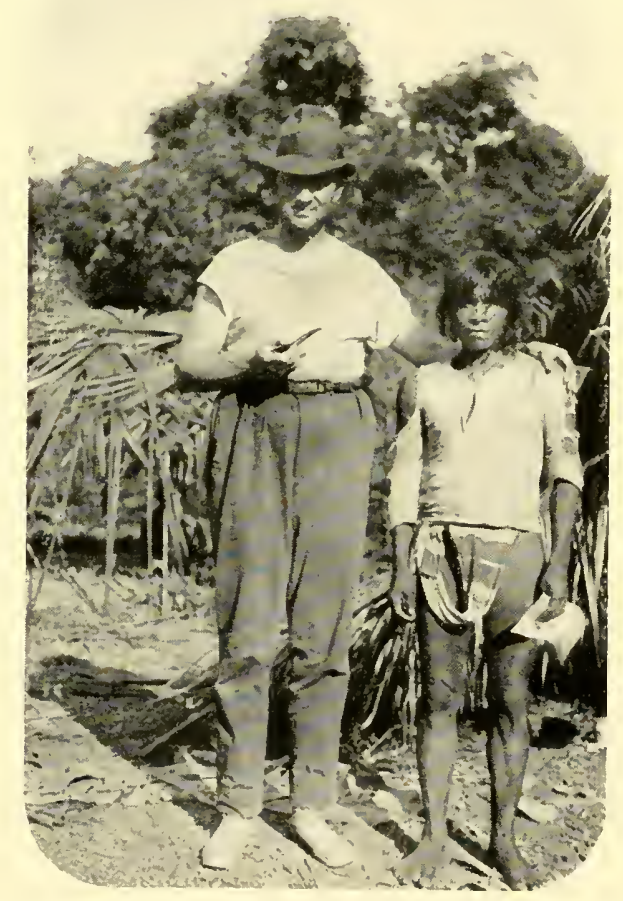

The author and Juicio, the chief of all the Chokoi Indians with whom we came in contact

It is a pity the facial painting with red anotto juice does not show in either photograph 

for primitive Indians don't like to give away their names any more than they do nail parings or bits of hair, which might be used to bewitch them. Dr. Alfaro, a high official of the Panamanian Government, went to Darien in 1922 in a schooner which he chartered, to adjudicate a disputed boundary between the claims of two oil companies. He offered us a ride. Winthrop Brooks and I were dumped, with our considerable gear, at a little village called Boca de Sabalo, at the head of navigation on the Sambu River. We went ashore, found a vacant palm-thatched hut with a pole floor, and hired it for a few cents. We laid down our floor cloth and set up our mosquito bars, for the place was a hotbed of malaria.

We had been advised in Panama by a friend in the Survey Department, Major Omer Malsbury, to ask for Juicio, who stood high in the councils of the Chokoi Indians. These Indians lived in the forests of this section of Panama and the adjacent portion of Colombia. The population of our little village was of mixed Indian and Negro blood, but they traded with the Indians who lived farther back in the woods. Next day Juicio appeared and Churima, and a number of others of less import, in a band. We took to each other at once. Juicio wore his hair in a long, straight black mane, with an orchid stuck over his ear and his face painted dizzily with the red derived from anotto. We explained what we wanted and he advised us where to camp.

We spent some time in Darien, moving our camp every seventh day and pitching our tents well away from any permanent Indian habitation. In this way even if we infected the local mosquitoes, for probably most of our 
camp followers were carriers of malaria, we kept one jump ahead of infection since it takes eight days for the mosquitoes to become vectors. Before long, a number of our Indians, including Churima, sent for their wives. This is a sign that one has won their complete confidence. As a matter of fact, they rather like Americans and distinctly dislike Spanish-speaking people, who were, and I suspect possibly are still, inclined to be afraid of them, or at least to patronize them. We possessed such mysteries as desiccated vegetables and dried soups, so that every meal was an adventure to the Indians, and they greatly appreciated the beads and other trinkets which we brought with us.

Mrs. Churima, as we called her, was a sleek, buxom damsel of tender years, very pretty, with a tiny baby slung in her bark-cloth scarf. She had a short skirt of trade cotton, I suspect a flour sack, and was industrious beyond belief. She rolled stones in search of frogs and lizards while the baby dozed. I never heard it cry, and never saw her put it down, even when she was hanging over the fire cooking.

Darien is warm and moist and we were there in the spring, when it was raining a good deal. I am pretty heavy and I remember a number of occasions when my Gold Medal cot sank down so that before morning I was in a puddle of water well tinged with humic acid, which seeped up through the canvas of the cot and greatly irritated my prickly heat. We got nearly a thousand birds, a number of them new, quite a lot of mammals, including a new arboreal mouse, and a wonderful new genus of lizards. We considered ourselves richly rewarded.

That mouse was a veritable gem among mice, a lovely 
little creature; the richest golden brown above and pearly white beneath, the line of demarcation between the two colors being sharply drawn. It fell to the ground from a tangle of vines pulled out of a tree to get a monkey which had been shot and which had lodged among the branches. Now this little mouse, which is evidently an arboreal species, was dazed when it landed and we caught it easily with our hands. We never saw anything like it again. It was not only a new species, but a genus new to Central America. Its nearest ally comes from Ecuador, and when Dr. Allen and I described it we called it Oecomys trabeatus, the adjective signifying in Latin "of regal dress."

The lizard was really something to brag about. I named him Diaphoranolis brooksi. Some of our Indians cut down a tree of a species that looks a good deal like a poplar and grows sparingly throughout the Darien region. It burns green with a good hot fire, although there is nothing which looks like rosin or pitch in it to explain its inflammability. This lizard, which fell out of the tree, was also an arboreal form, related, but not very closely, to the "chameleon" of our Southern states. In other words, naturalists would call it an anoline lizard. It was pallid white, with many black markings sharply defined. The pendulous dewlap, which in this case was not extensible as it is so often, was not decorated with flash markings. The head and the neck and the dewlap thus were all similarly marked with a network of coarse black lines. There were two black saddles on the back and nine black rings on the tail. The most interesting feature of all was the fact that the limbs and the digits bore many pairs of sharply defined black lines occurring as rings, which, however, did not quite meet on the inner surface. 
Thus the little lizard looked as if it wore old-fashioned lace mitts. I never saw anything like it. At the risk of being prolix, I quote from my notes: -

The region is one of high, damp, humid forest, gloomy and stifling except where some watercourse cuts through the wooded lowlands, letting in the sunlight. Decay of fallen wood and leaves is very rapid and the dark forest floor is sodden and slippery. In general, reptiles were surprisingly rare, and often a day would pass when none of us would see a lizard, unless when coming to the shore of some small stream the bipedal basilisks would scurry away. The young far outnumber the adults and all are well able to run with equal ease over land or the face of the water. While they are running over either surface the body is held almost upright, the tail is raised as a balance, and the fore limbs are tightly pressed to the sides. They move and stop with a speed and precision which seems mechanical rather than animate. The paucity of adults and the shyness of both young and old bespeak abundant enemies, but of what nature we were never able to learn.

One afternoon an Indian who had been gathering firewood came in carrying a small lizard, and we then saw for the first time the young of Diploglossus monotropis, already known from Costa Rica and Colombia. This little creature, about seven inches long, was so gorgeously colored while alive and so different from the preserved examples that my field notes are again worth quoting: "This specimen, seven inches long, has a gray-green head, bril- 
liant carmine sides covered with anastomosing black lines; belly yellowish; back and tail black with beautiful narrow blue-gray, almost mauve crossbars." I have never seen such a gaudy little critter except my Diploglossus resplendens from Bolivia.

A few days after our Upper Jesusito camp was made we began to fell trees to let in sunlight and breeze. As it turned out, there was no breeze and the sun was almost constantly obscured by rain clouds. One tree came down with a crash and brought with it a living and uninjured Corythophanes cristatus. The interesting point in connection with this capture was that we kept the lizard alive long enough to find that its actions were singularly chameleonlike.

It was sluggish and deliberate in its movements, and when angered it reared upright, flattened its body vertically, and bent down its head. Its mouth meanwhile was opened widely in a way that recalled at once captive and angry African chameleons. That the very peculiar superficial similarity of appearance should be accompanied by such similar sluggish movements and curious attitudes is most noteworthy and almost incredible when the protean zoologic gap between the two genera is considered.

In a few places where the forest roof leaked spots of sunlight the ground dried out and the great, curly, newfallen leaves made noisy walking. In these little dried-out spaces we found some tiny lizards. They crept swiftly and stealthily over the big dead leaves, and when the sun was hidden, as it often was because of the frequent showers, these little lizards hid at once, to reappear when their moldy abode became dry again. They were not easy to 
catch, and even when caught a decent specimen was by no means assured, for their skin tore like wet tissue paper and their struggles usually left them sadly unfrocked.

These, like other slim-toed Gekkos or Eublepharids, as they once were called, are far more agile than their allies with dilated digits - more alert and less deliberate in their movements. The species proved to be the rare and little known Latbrogecko sanctae-martae Ruthven.

At the end of our stay in the Sapo Mountains a message came that my daughter, Mary B., had been operated on for a tracheotomy and was not expected to live. A tiny launch, in bad condition and belonging to the schoolmaster, was the only transportation to be found. Into this we piled our precious gear, which filled it completely except for a little space for the engineer and for the steersman for'ard, while we stood on the tiny deck aft, with our elbows resting on the canopy top, and here we dozed, taking turns at watching one another so that neither of us fell overboard, for about thirty hours. Once our engine went dead and we drifted out of sight of land and were unutterably pleased to hear it start sputtering again.

At long last the flashes of sunlight reflected by the pearl oyster shells embedded in the stucco of the cathedral towers of Panama told us we were nearing our destination. And when we learned at the Legation that Mary B. was well and had been for weeks, I leave it to your imagination to guess how much champagne we consumed. Before this process began, be it said, I walked up to the desk of the Tivoli Hotel to sign for a room and the clerk never even recognized me, although we had known one another for 


\section{Those Who Help}

years. We were a couple of tired and gaunt-looking shadows, but supremely happy.

Years later I went back to Darien with a party of friends. We chartered a terrible old hooker called the Augusta Victoria. After we appraised the rat bites and insect bites incurred during the voyage, we changed her name to the Angustia. Things had changed when we got to Garachine. One of the big oil companies was drilling on a considerable scale and a lot of rather rough diamonds from Texas and Oklahoma dwelt in well-screened houses near where once we had camped. A muddy track ran inland from the "port," and a Ford truck drove us through the forest to one of the camps for luncheon.

I was sitting on the back of the truck with Ned Hammond and Frank Hunnewell, when whom should I spy but Juicio. I stopped the truck. Juicio stepped forward with that entirely self-possessed manner which is the inimitable attribute of the American Indian everywhere, came up to me, put his arms around my neck, patted me on the back, and said, "Que bay, viejo?" (How are you, old man?) Then he went on to tell me how times had changed and how he and his people loathed the Americans who had settled on their lands.

Some of the drillers, however, had seen the little drama of our meeting and were unbelievably surprised. One of them said, "We can't buy fresh meat for love or money from those Indians." I said, "What do you want?" "Venison," he replied. "I will see what I can do." Juicio and a number of his friends had gathered, squatting at the foot of a gigantic quipo tree, and I walked over and joined the group. I asked them if they would sell me some deer meat. 
They said, "Certainly. We have a deer which we killed this morning hidden within a hundred yards of where we are now." I told Juicio to give it to me for old times' sake. Within ten minutes he turned up with a brocket, dressed and with the head cut off. I gave the little deer to the drillers and they certainly thought that we were magicians.

In Darien Brooks and I suffered several times from finding the larvae of a botfly in our skin. Curiously enough the eggs seemed to be laid usually between our shoulder blades in a particularly difficult place to scratch. The larvae grew fast and caused great discomfort, and being beset with sharp, spiny hairs they cannot be gotten out by ordinary pinching and squeezing. We knew from the natives that they could be narcotized by tobacco juice and we chewed up pieces of cigars, rubbed the tobacco juice on the area, and when we ceased to feel the larvae wiggling under our skin we found that they were stupefied by the nicotine and could then be popped out.

The grubs of this botfly were relatively few and far between until years later a lot of infested cattle were brought into the Canal Zone pastures from the Orinoco River district in Venezuela. I of ten saw these in the pastures near Summit in Panama. The flies which they brought in with them multiplied until the cattle became a fearsome sight, covered with festering, running sores so that they became thin and poor from the pain created by the wabbles, and their skins were worthless when they were slaughtered.

I didn't learn until some years afterwards the curious life history of this horrid pest. The fly itself, Dermatobia 
bominis, apparently does not lay its eggs directly on its host but captures other flies, usually of the genus Limnophora, or mosquitoes, and lays its eggs upon them, releasing them immediately. These then light upon man or beast and the egg, adhering to the skin of the host, hatches at once and the larva quickly dives beneath the hide of its victim. The most complete account has been given by my friend Lawrence Dunn, a medical entomologist in the Gorgas Memorial Laboratory in Panama. Seated at the edge of a small stream near Summit in October 1929, he was infested by six of these larvae, two on each forearm and two on his right leg. He recognized at once that here was an opportunity to study the emergence of these creatures in great detail. He returned to the laboratory and in spite of the most exquisite torture and the revolting fetid discharge from the wounds as the larvae increased in size, he patiently waited no less than fifty days until the creatures finally emerged. They weighed each about 0.725 gram and were each about 25 millimeters long and i m millimeters in diameter. His account of the final stages is worth quoting, for while innumerable travelers have suffered from these beasts, never before has the exact time between the laying of the egg and the emergence of the larva been made known. After they dropped from his skin Dunn placed these larva in damp sand and twenty-five days later the adult flies appeared.

Brooks and I never were infested more than a few days before we got rid of the beasts. Dunn's incredible patience and penetrating observations mark him as a pioneer with the spirit of a born investigator. 
November 27. Larvae Nos. I and 3 were quiet and gave very little trouble during the night, but this morning they became active and protruded so far that I thought they were about to emerge. No. 3 continued more or less movement during the early morning and the dressing was removed several times to see what was taking place. At each time the larva was partly out of the hole, but it always withdrew again after coming out about so far. At io A.M. a movement was felt on my skin at the lesion and upon examination the larva was found to be coming out. It appeared to be doing very little struggling, yet it slowly came from the hole and dropped over on my arm.

I may add that I have never yet seen a howler monkey that was not infested by these botflies, nor have I ever seen a marmoset or other species of monkey that was. The howlers evidently do not know how to get rid of them and I have, on two occasions at least, found a howler monkey that had fallen in a dying condition to the forest floor, evidently seriously weakened by a heavy infestation of these awful fly larvac. 


\section{CHAPTER XVII}

\section{Panama}

I

THINK nine friends out of ten, if asked to speculate on the best job I had ever done in my life, would agree that the help I was able to give the Barro Colorado Island Laboratory ranked first.

The story is not without drama. It began in a drab, bickering meeting of scientists in Washington, and was followed by the organization of an "Institute" which existed only on paper and which apparently was unlikely ever to serve a useful purpose. Then, with the flooding of Gatun Lake in Panama, came the realization that an island was created out of what had once been a tropical hilltop. James Zetek, Richard Strong, and William Morton Wheeler persuaded Governor Morrow to set the island aside for scientific purposes, and thus in 1923 imaginations began to kindle. This letter of Dr. Wheeler's tells its own story: -

$$
\begin{gathered}
\text { Washington, D. C. } \\
\text { July } 7,1923
\end{gathered}
$$

MY DEAR FAIRCHILD: -

I have just returned from Woods Hole where I had a long talk with Dr. Schramm in regard to the Barro Colorado Laboratory. On my return to Boston I also talked over the matter with Dr. Barbour. Both of these gentlemen feel, and I heartily agree with them, that it would be advisable for the Tropical Plant Research 
Foundation to incorporate and take this laboratory under its wing as one of the places in which researches in tropical botany and zoology could be carried on. We also feel strongly that you ought to take over the supervision of this laboratory and probably other tropical laboratories, such as the new marine laboratory which President Porras is founding in Panama City, and let us help you in developing them. ...

I take it that students of plant diseases and the economic entomologists would be glad to have a number of stations in which they could carry on investigations under different conditions in the American tropics. The zoologists have usually taken the lead in the development of marine stations but have always made room for the botanists who desire to carry on investigations in these institutions. Since botany and zoology can no longer be separated, I believe it would be admirable if the botanists could take these various tropical laboratories under their wings and let the zoologists come in to help them. This seems to me to be the more proper because the plant life of the tropics is such a tremendous and basic affair and so essential to the development of all animal life in those regions. ...

I do hope that you will think favorably of this matter, which I should like very much to present to you in greater detail. This would be best accomplished in conversation. I am so glad to learn that you are enthusiastic about the Barro Colorado proposition. We can get Mr. Zetek to look after the laboratory when no investigators are there. I contemplate going to Pan- 


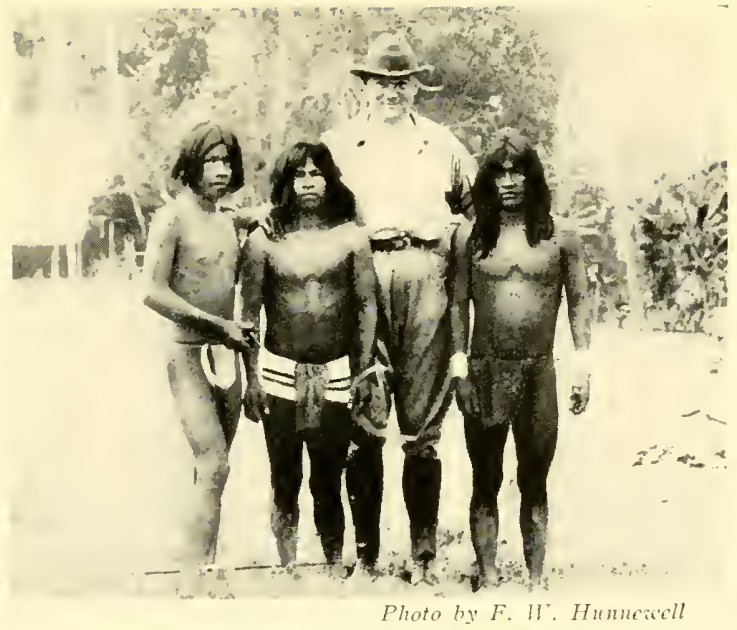

The author with three Indians near Garachiné, western Panama, 1922

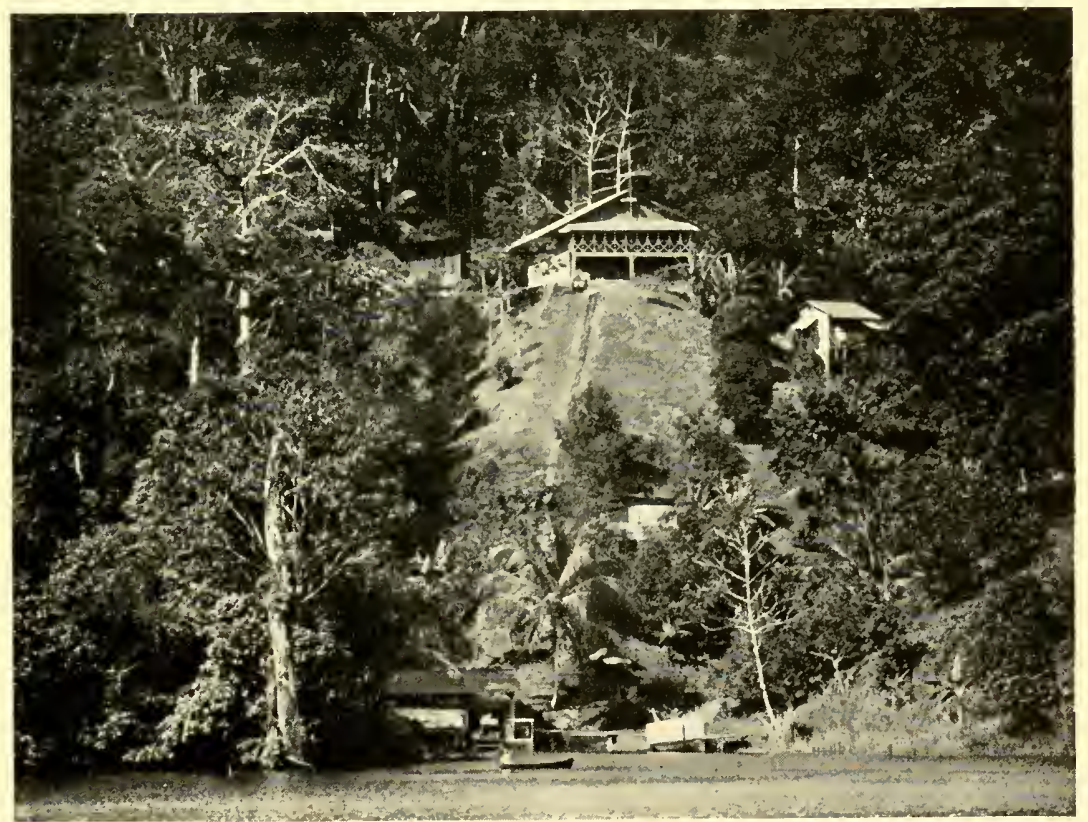

Photo by James Zetek

The Laboratory at Barro Colorado Island

To the left of the main building may be seen the roof of the anthor's little cabin. Directly bebind it and a little farther up the bill is Frank Chapman's loonse. James Zetek's is to the right and shortly below the main building 



\section{Panama}

ama during the summer of 1924 with one or two of my students, and was delighted to hear that you are thinking of being there with your son. Dr. Barbour and I have arranged with Zetek to have one of the Canal Zone buildings taken down and put up on the island, so that probably within a few months the station will be open for work. Even at the present time Mr. Shannon of the Bureau of Entomology in Washington is living in a shack on the island and doing work on mosquitoes for Dr. Dyar. We may say that the laboratory is actually operating. It is now up to you and the Tropical Plant Research Foundation to give it a good boost.

With kindest greetings to yourself and Mrs. Fairchild, I remain

Yours sincerely,

\section{W. M. WHEELER}

The fact that Wheeler planned to be in Panama the summer of 1924 meant that, if any building was to be done, then was the time. So James Zetek and I put our heads rogether. The idea that this marvelous stand of virgin forest, nearly eight square miles in area, might be made permanently available for biological studies gave impetus to us both.

There was no appropriation, but gifts of cash came in from David Fairchild, Barbour Lathrop, and others. For my part, the building was made possible by the fact that I was particularly flush in 1923 . In those days, if you were willing to speculate you could make money, and I had quite a lot on hand at the time - enough to buy out the 
settlers who had homesteaded and started to grow bananas on the island, and also to put up the buildings, lay a track, and set up a hoisting engine to carry supplies up the 362 steps from the lake shore to the Laboratory at the crest. A tremendous amount of credit goes to Zetek for his ingeniousness and foresight. He and I bought an amount of material from the Panama Canal's obsolete stores. The begging and borrowing we did from the Army and Navy as well as the Canal officials - borrowing especially in the shape of brains - put us in debt to many people.

The question in the beginning was how we were to receive the Federal recognition which was necessary if we were to operate efficiently in the Canal Zone. Someone remembered the paper "Institute for Research in Tropical America," and the Barro Colorado Island Laboratory was committed to its care. From then on, the annual reports were made to and circulated by the National Research Council, and to all intents and purposes the Laboratory was the Institute.

This arrangement made it possible for us to give visiting scientists commissary privileges, hospital facilities, railroad passes, free entry through the customs, and the right of residence in the Canal Zone. It also made possible the purchase of ice and all other supplies and their delivery at the Frijoles Station of the Panama Railroad by the Commissary Department of the Panama Canal. If it had not been possible to devise this quick tie-up, the whole development of the Laboratory would have been long delayed.

The Laboratory and its work have now become widely known. Thousands of people have read My Tropical Air 


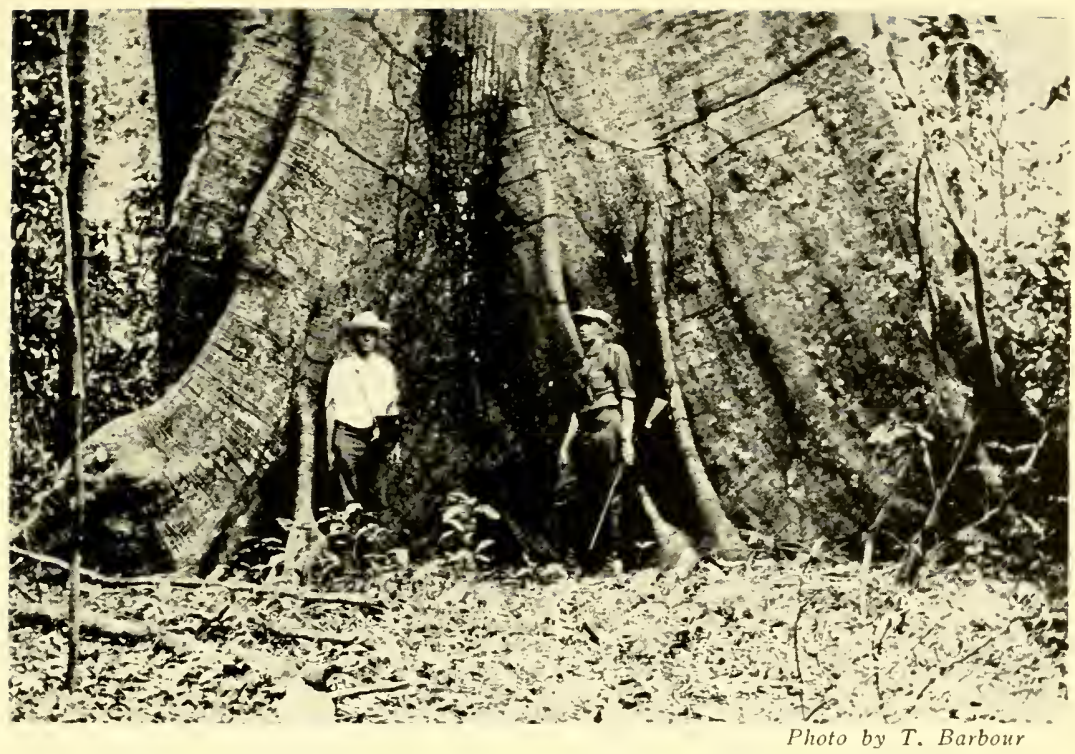

One of the giant Bombacopsis on Barro Colorado Island

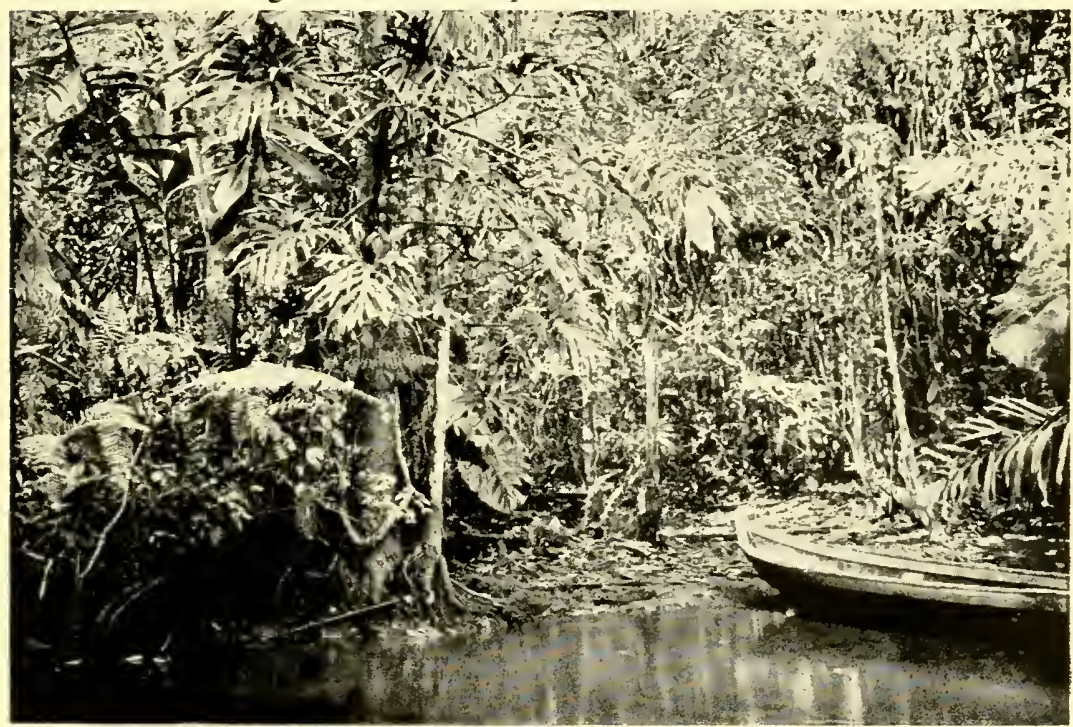

Photo by J. Zetek

Shore-line vegetation at Barro Colorado Island 

Castle by Frank Chapman, the great ornithologist. My pride in having built the castle is very deep, not only because it provided the setting for Chapman's matchless stories, nor because at least four hundred scientific papers have been based on studies made there, but for an entirely different reason. The building of this Laboratory has made it possible for the teacher of biology with a small salary to have the thrill of Wallace, Bates, and Spruce when they first set foot in the Amazon jungle.

Our incomparable forest, within a hundred feet of the Laboratory door, is as fine as anything to be seen in Brazil. The great espavé trees tower up almost out of gunshot to where their side branches stretch out and interlace with those of other trees, each branch as large as a giant white oak and covered with a garden of ferns, orchids, and bromeliads. Near the spot which I have in mind there is a giant Bombacopsis tree, its trunk supported by natural flying buttresses, making stalls where one could stable elephants.

To see these trees and to walk our carefully marked trails provide all the illusion of exploration, but with this great difference: we have pure drinking water. By care. fully testing the blood of our employees, we can keep malaria off the island so that students can walk our trails at night with a headlight; if one is ill, our launch crosses the Canal in forty minutes to Frijoles Station on the Panama Railroad; there is a hospital car on every train, and less than an hour's ride is Gorgas Hospital at Ancón, as fine as any in the world. Our establishment provides comfort but nor luxuries. Our food is simple, hence served at a small cost. A high-school teacher of biology who had 
saved up \$250 before the war could go and live in the midst of the jungle, with monkeys, parrots and toucans, trogons, motmots, and innumerable other denizens of the lowland tropical rain forest easily observed on every hand.

Strictly speaking, the Canal Zone of Panama is not a possession of the United States. It is, however, a perpetual leasehold, and differs from all other American interests in the tropics in that it is on the mainland. There are two bits of mainland tropical rain forest in the possession of the United States: one is Barro Colorado Island and the other is the forest reserve which I persuaded Governor Harry Burgess to set aside along that stretch of the road from Summit to Madden Dam which is within the Canal Zone. The rest has been cut down to provide room for cultivation. The climate at Summit is somewhat drier than it is on the island, and the two spots of forest are quite different, botanically and faunally.

Until a year ago the Laboratory was supported by table fees, small sums paid by ten or a dozen institutions to enable officers and students serving them to stay at the Laboratory at special rates. The Governor of the Panama Canal allowed us railroad passes, the right to purchase at the commissaries, and hospital privileges. But a year or more ago the island was taken over by the Government and renamed the Canal Zone Biological Area. The Institute is now an independent entity like the National Academy of Sciences and the Smithsonian Institution.

We are no longer tenants at will who could be ousted by an unsympathetic governor, and we have a permissive appropriation of $\$ 10,000$ a year which Congress quite characteristically fails to appropriate. Now, of course, the 
institutions, being eager to save a dollar wherever possible, have tried to welsh out of paying their table fees on the ground that we are on easy street financially. Just the reverse is true, and it looks as if the old familiar pastime of making up deficits might continue. The island is now governed by a board consisting of the Secretaries of War, Interior, and Agriculture, and three Naturalists, with the President of the National Academy of Sciences as Chairman of the Board. If it were not for the amazing wizardry with which Paul Brockett weaves his way through the intricate maze of Washington red tape and the equal skill with which James Zetek treads the same path in the Canal Zone, my unpaid job as the Executive Officer of the Canal Zone Biological Area would be a far more arduous pastime than it is.

I was in the Canal Zone frequently between 1916 and I 936 and was often included when parties were made up to visit the Chillibrillo Caves on the headwaters of the little stream of the same name. These caverns were the objective of many a pleasant picnic. I went several times with Meriwether Walker and his wife, Edith, when he was Governor of the Canal. We assembled at Gamboa, took a police launch, went up the Chagres River, then the Chilibre, and so into the Chillibrillo and to the caves.

My hosts allowed me to wear old clothes, and I collected in the caves while the picnic luncheon was being prepared. Of course on these excursions I had first-class electric lights, one on a headband and one portable. The unbelievably large bat population in these caves was extraordinary, not only for the number of individuals but 
for the tremendous variety of species. In fact, on every visit I found a bat or two that had not been taken previously, and I suspect the same thing would happen if I returned there tomorrow.

The caves were incredibly noisome and hot, and I was certainly a mess at the end of each sortie. I recall that one day I rode back on top of the launch because I was in no wise fit company for the ladies inside. The Governor joined me on the roof, and we sat looking at the scene of exquisite beauty which unfolded itself as we passed bend after bend of the Chagres River. The little clearings were not conspicuous, and great stretches of untouched tropical forest billowed away on either hand. The guayacan trees were in bloom and the whole scene looked as if some giant had passed over it with an overflowing bucket of molten gold, big blobs representing giant forest trees and little spatters the lesser trees poking their heads up through the roof of the jungle. This is one of the most spectacular shows staged by nature anywhere in the world. It is a pity the bloom lasts only a few days.

Looking out at this scene, the Governor said to me, "If only this country wasn't cursed with malaria." That remark set me thinking. There we were, riding on the river whose very name is synonymous with pestilence. I suppose there are millions of people who have heard of Chagres fcver and who have never heard of the Chagres River.

If only malaria had not come to America, how different everything would have been. Is it not a fair assumption that when Alexander's army brought it from India to Greece the light of Greece waned? It is not unreasonable 


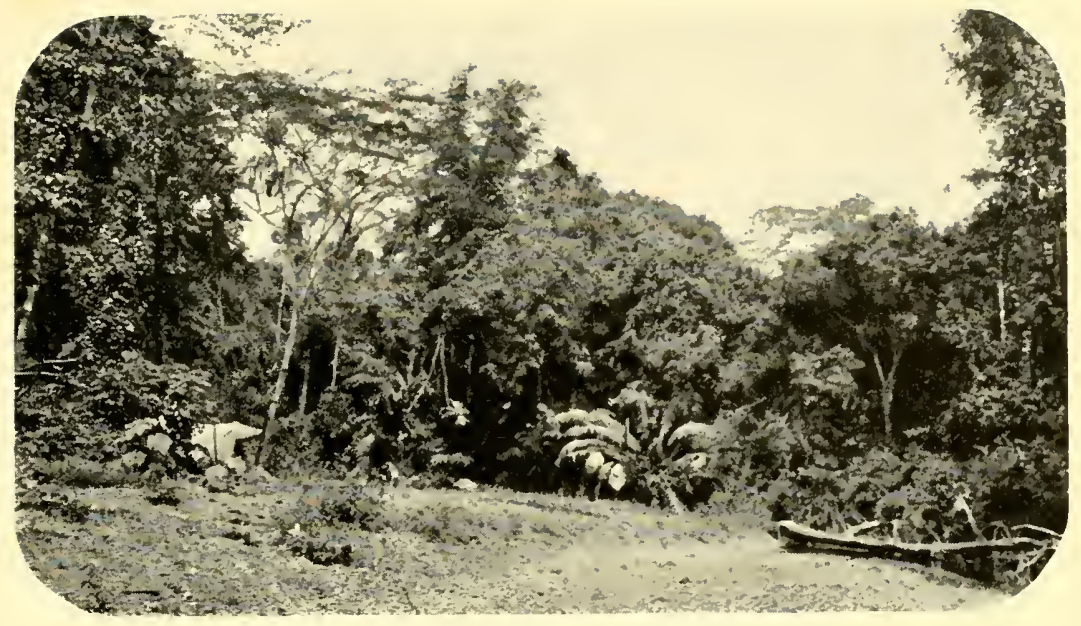

Our tent (on the left) by an almost dry stream in eastern Panama

The Indians made us change the location of this camp as they feared a sudden "cresciente" at night

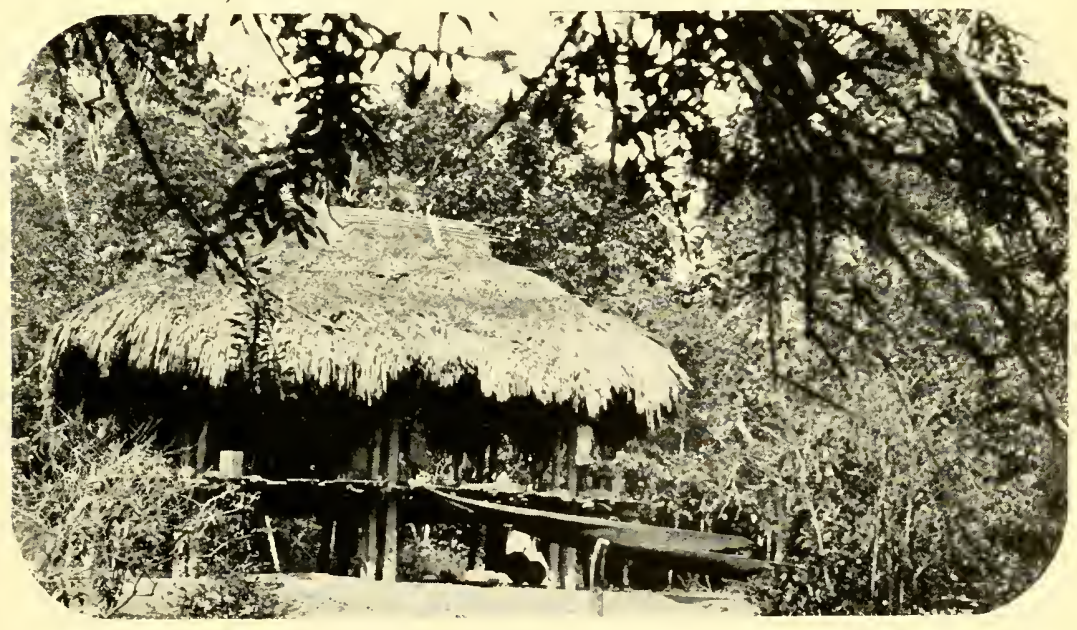

Churima's house, where we hung our mosquito bars on various occasions 

to suppose that the same thing happened with Rome. Whether it reached America with Columbus or not seems very doubtful. I am not a medical historian, but it is quite obvious that Cortez, equipped as he was and with the number of followers that he had, could never have marched from Mexico City to where Trujillo in Honduras is now, if malaria had stalked abroad in the land. No disease in the entire world causes so much suffering and incapacity as does this one; and for the untold number with whom quinine does not agree, the use of this drug, either as a prophylactic or as a curative agent, means suffering almost as bad as that of the disease.

One dreads the temptation which some day is going to come to many people to motor over the Pan-American Highway when it is completed. They little realize the misery which will be theirs from carelessness or lack of knowledge in warding off this disease. It can be done, but it cannot be done easily.

Probably the fault is entirely mine, but the published reasons that moved the Peabody Museum to excavate at the Sitio Conte in Coclé, Panama, are not correctly set forth in the Memoirs describing the finds. The matter is not important, but it illustrates in a peculiar degree how chance governs all sorts of things besides our digestion. My wife and I were in Panama in August 1928. We were house guests of Meriwether and Edith Walker. I remember the question of shopping came up one morning at the breakfast table, and I said to Rosamond and Edith that I hoped they would stay out of shops in the congested center of Panama City - because there was an 
epidemic of severe influenza running riot at the time. Fortunately they paid no attention whatever to my advice and, poking about, they went into the funny little rat's nest of a curio shop kept by an old German named Peter Hauck. It was the most slovenly, messiest little hole in the wall that anyone ever saw. But Peter Hauck, for all his squalor, was a shrewd, intelligent person. They bought a few objects as ornaments. I recall an interesting little stone figure which Rosamond gave to Edith as a memento of our visit. At noontime I admired this and asked where it had come from. I was told, and Rosamond added that she had seen an extraordinary little stone pelican partially ensheathed in gold which looked utterly unlike the gold figures which are frequently dug up in the Province of Chiriqui and are even more frequently faked for sale to tourists. She said that Hauck had a number of other things from the same locality, but that he would sell them only to a museum and that he did not want the collection dispersed.

Well, I could not wait to get to Peter Hauck's shop after luncheon was over. I found that he quite obviously was securing material from a region that promised to be a rich treasury. I bought the collection and had it shipped to Cambridge. My address being given in care of a museum, he was entirely willing to dispose of it at a quite reasonable figure.

When the specimens arrived and were examined, considerable correspondence ensued with Mr. Karl Curtis, an ardent amateur of archaeology and an old employe of the Panama Canal, a warm and sterling friend of us all. He it was who found that the floods of 1927 had washed deeply into the sides of the river in the pastures of Don Miguel 
Conte, near Penonomé in the Province of Cocle. Dr. Edward Reynolds, then Director of the Peabody Museum in Cambridge, persuaded Professor Tozzer and Professor Hooton to go to Panama, to visit the Conte family and to draw up a contract allowing the Peabody Museum to carry on explorations. These excavations produced vast stores of pre-Columbian objects in pottery, stone, gold, and even emeralds - and the whole discovery was the result of not taking my advice about Panama City and the influenza epidemic. I may add, also, that no one got influenza.

I wish I had my daughter Mary's ability to paint a picture in words. If I had, I could make it possible for you to see with me the loveliness of the coming of day on Barro Colorado Island. I have a mind to try. I will assume that you, my gentle reader, are another mere man, of course. Otherwise I could hardly say what I am going to say with propriety. How would you like to come and spend the night with me? I have a spare Gold Medal cot which can be set up in a moment, and the Spaniards taught us generations ago that canvas drawn taut was the ideal substratum on which to sleep in the tropics. Anyone who camps in the North knows that you get colder from below and must sleep on blankets more than under blankets. But not down here. You can have a thin sheet to pull up just before dawn, but otherwise we won't have to bother about bedding.

I have insomnia and awake with ease, so that if I hear any footsteps on our roof I will call you and we will step out with my big electric flashlight. It is likely that you will get a glimpse of one of our several species of pretty little opossums, or a night monkey, brown and furry, with 
the puckish little face of a very imp. Of course if it should be rainy, you would hear some interesting frog calls, but I can promise you nothing in the way of an amphibian chorus to be compared with the unbelievable roar and din, a veritable biological boiler factory, which you can hear around the University of Florida at Gainesville - in the spring - and learn a lot about if you have Professor Archie Carr to identify the calls for you. This, as I say, I cannot promise, but you will hear some frogs and toads, and innumerable insects. I shall set the alarm clock for about five forty-five. We are near enough to the Equator so that there is only a few minutes' difference in the length of days through the year and, as you no doubt know, day comes and night falls quickly in the zone between the Tropic of Capricorn and the Tropic of Cancer.

We will assume now that the alarm has rung and step out on our little screened porch, which presses directly against the front of the great forest. Sit down with me in your pajamas, so as not to waste time, as the sky begins to pale, just as the first pair of parrots flies overhead, their acrimonious vituperations, one to the other, bespeaking their haste to reach some distant feeding tree. By great good fortune a pair of macaws may fly over, but they are rare and have almost disappeared from this part of Panama. If they should pass, they will give a demonstration of avian billingsgate completely unrivaled. If you want to hear paroxysms of connubial discontent shrieked out over the treetops, listen now. It is too early to watch for the toucans, but they will volplane over our heads before long.

Look out and see that great white balsa-tree blossom tremble. Its pallid chalice seems to tip sidewise. As it grows 
a little lighter, you will see a white-faced monkey sipping his eye opener. The great blossom contains rain water, some nectar, no doubt, the mixture generously spiced with drowned insects, so that the draught is surely nourishing. $\mathrm{He}$ is only one of a dozen or more that spent the night roosting near by. A pair of marmosets bicker on a great vine. Now it is light enough for the howling monkeys high overhead to open their roaring competition. Each one, great and small, sounds certainly as if pre-eminence in roaring had suddenly become a most ardently desired attainment.

Wild figs, so-called (they are not figs at all), begin to sound like giant raindrops hitting the jungle floor. This means that the Pavos are up feeding in the tall tree and shaking off more fruit than they devour. These great birds, locally called turkeys, are in truth not distantly related to those birds. Ornithologists will recall them as Penelope. Now the colony of oropendulas awakens, enormous orioles, their great nests swinging, not from the breeze, for the morning is dead still, but as the birds hop in or out and thus set them in motion. They keep up a constant musical clatter, quite like the jangling of a peal of bells, and Panamanians declare they are talking Chinese. What they do they certainly do incessantly.

Coatis, their long tails erect and curved and their long Paul Pry noses sniffing about the lawns, jump for a cricket or mumble a fallen fig with equal gusto. As with all the tribe of the raccoons and bears, their appetite is as liberally omnivorous as my own. Perhaps this morning, as often happens, there will be a short, sharp shower of rain and everything will become hushed and still, and as the shower 
passes the pageant of sounds, if one may use such a simile, is re-enacted and you have the fun of listening all over again.

Nothing ever impressed me more than when Johnny Sessums, who was General Preston Brown's flying aide, once told me that 5000 feet over the island he could see what looked like blue sparks snapping against a background of green velvet. I knew at once that it was the sun striking the wings of the giant Morpho butterflies, the upper surface of whose wings is a solid sheet of metallic azure. This sight I have never seen, though my daughter Mary B. and my wife have flown with him high enough to see far out into both oceans. But they do not get seasick as I do.

There are twenty-five miles of shore line to our six square miles of island, which shows that it is deeply embayed. The island supports 1800 species of flowering plants, about 70 species of mammals, and something over 275 species of birds. This is the equivalent of what might be seen in Massachusetts in a year of observation of resident and migrant birds together, and Massachusetts is 1366 times larger than Barro Colorado Island. But these figures help no impression of the beauty of the place.

Probably few spots in the world have provided more intellectual thrills or satisfied more intellectual curiosity than has Barro Colorado Island. Every naturalist, be he high-school teacher or independent investigator or college professor of biology, craves a chance to see a tropical rain forest, if only for once in his life; and many who have had their first chance on Barro Colorado Island have returned there again and again. 
The Laboratory is now closed, maintained by a skeleton crew in charge of Mr. Zetek. The tropical forest is so intolerant of the invasion of its realms by man that all vestiges of our occupation would disappear in a short time if we did not keep a crew there. Even our "graveyard" would soon disappear. This consists of stumps of wood prepared with all sorts of materials supposedly or actually useful in protecting the wood against the ravages of termites, the greatest scourge affecting wooden buildings in the tropics. These test sticks, planted in the ground at exactly the same depth, under the same conditions, and carefully watched, are now, after fifteen years of Mr. Zetek's penetrating observation, beginning to produce information of great value.

I don't know whether I shall ever see Barro Colorado again, but I certainly hope that I may, if only to sail by it through the Canal in the month of March, when the guayacan trees lift their lofty heads above the forest top, each as glittering as a golden dome, while the purple Jacarandas, the pale pink almendros, and the Palo Santo with flowers as crimson as arterial blood make a scene of incomparable splendor. 


\section{CHAPTER XVIII \\ Scientists and Philosophers}

\section{I}

NEVER could see eye to eye with my Grandmother Barbour in her great admiration for Thoreau. As I said in my introduction to Concord River by William Brewster, I feel that Thoreau's ego was always too near the surface and he was too constantly crusading. He seems to me smug and self-satisfied, preening himself for his "passive resistance," though why one should seek credit for not paying one's taxes is hard to see. Civil disobedience was as natural to Thoreau as it is to Gandhi, and however saintly the latter may appear to his followers, to most Americans in this struggle for survival he cuts a slightly ridiculous figure.

Thoreau loved to philosophize, and it has always seemed to me that his natural-history notes, though written in a charming English style, were those of a man with a very inadequate background. William Brewster, for many years the Curator of Birds at the Agassiz Museum, was much better, a peerless observer and one not given to moralizing.

Some years ago my friend Lawrence Henderson got all tittered up about Pareto. I had my tongue in my cheek, but finally consented to buy Pareto's two huge volumes, Traité de Sociologie Général. I simply could not suffer through it. David Fairchild and others of my friends, including Wheeler, ate it alive, but my poor mundane mind saw 
nothing but the words. It was said that Mussolini had been considerably influenced by studying Pareto. As I look back on it, it may perhaps be concluded that this was not an overwhelming recommendation for the book. I like to read books concerning history, biography, travel, adventure, detective stories, and shrewd observations concerning animals or plants. But philosophy is completely beyond my ken; it not only bores me, it irritates me, and after a bout of Pareto I become absolutely unfit for human companionship.

The men whom I have derived the deepest satisfaction from meeting and thinking about have usually not been thinkers in the strict sense of the word. Time and again I have recalled the delight of meeting William H. Ridley. He was Director of the Botanic Garden at Singapore when David Fairchild and Barbour Lathrop visited the Garden in I 897. He was still Director when I presented my letter of introduction to him from Dr. George L. Goodale. It was Ridley alone, among all the directors of the gardens in British colonies throughout the tropical world, who began to experiment with the rubber seedlings distributed by Kew Gardens after the first batch of seed was bootlegged out from Brazil. He studied the variation in quality of the latex in the different trees and methods of tapping. Although it was slow in coming and the British and Dutch planters of the Malayan region took a lot of coaxing, when rubber culture once took hold it went forward with a rush. About the time Brazilian forest rubber reached $\$ 2.10$ a pound, plantation rubber began to appear on the market and in a few years the Brazilian rubber town of Manaos was a deserted city. Probably not one person in a thousand has ever 
heard Ridley's name, but yet the development of Malayan rubber owes more to him than to any other man.

Chatting once with Mr. Lowell in the President's office a few years ago, after we had been talking about some of the peculiarities of my older colleagues, I said to him, "Why doesn't the present generation produce any of the curious figures that stalked across the Harvard stage a generation ago?" He turned and, with his charming and whimsical smile, said, "Buy a mirror."

While I received my Bachelor's and Master's degree at the hands of President Eliot, I received my Doctor's degree the first year that Mr. Lowell presided at Commencement. I had already become connected with the Museum at Harvard in a modest way, so that I served Mr. Lowell during the entire time of his presidency, a fact which I look back upon with the greatest pleasure and satisfaction, for no one ever served a more worthy master.

I remember the day before he was to be inaugurated. We walked together across the Yard. He stood for a moment near Massachusetts Hall and surveyed the sea of seats which had been set up for the benefit of spectators on the morrow. He remarked, "It's hard for me to believe that so many people should want to come to see that show tomorrow." I replied, "Mr. Lowell, if there were a gallows set up in the Yard and you were to be hanged on it, there would be five times as many people who would want to be here." He replied, "I guess you're right." Now this is not a very touching story, but the point is that Mr. Lowell was sufficiently humble-minded not to take offense, to 
observe that I was a bit of an ass, or make any other such remark, which would have been perfectly justified. $\mathrm{He}$ was a realist then, as always.

Professor Nathaniel Southgate Shaler was a curious, lovable figure. He offered a so-called research course and I happened to be the only student in it the year of his death. It was during my study with him at his home that he told me a memorable story. I wish I could conjure up a picture of our meeting. Shaler was slender, all wire. He spoke rapidly and with great precision of utterance, and from time to time he stroked his beard and then ran his hand up the front of his head, so that his hair frequently stood up in a way which matched his beard quite strikingly. His plan was to prepare a simile to present in one of his lectures in Geology 4; he wished to illustrate the fact that it was fortunate indeed that we had the phenomenon of death. What, he argued, would the earth be like if every animal that had ever been born had continued to live forever? I allowed that it might be difficult to make this most unhappy possibility very vivid. "Nonsense," replied Shaler, "I have thought of an example. Given a single parthenogenetic plant louse, one of those little bugs which can reproduce its kind without the presence of the opposite sex. Now, if all the progeny of a single plant louse should live, I have calculated that at the end of a year we should be faced with a column of plant lice having a diameter equivalent to the distance from Quincy to Brattle Street and thrusting itself upward through space with three times the velocity of light." Having made this perfectly astound- 
ing statement, Shaler looked at me sharply. I said, "You win, Professor. You have certainly made this as vivid as it could conceivably be" - which certainly was true.

I had a letter not long ago from an old friend who knew that I was writing some of my recollections. He said, "I think that a chapter would not be amiss laying stress on the importance of scientific education."

Well, that's just what I'm not going to do. If there is anything that is being overstressed at the present time it is the importance of scientific education. I should much rather advise every boy to prepare himself with all the Latin and Greek which he can pack in, round this off with good English reading and a modern language or two, and he will have the firm basis for any education.

I think the scientist is born, not made; I know the mathematician is, and the physicist and the chemist as well. These sciences are so inherently unattractive in themselves and involve so much drudgery that no one ever tackles them seriously who is not born with an innate urge to study them.

I entered Harvard College, of course, under the old plan with lots of separate examinations during several consecutive days. I am happy to say that I passed well in Latin, Greek, and German, though I failed utterly in physics - a condition which I should still be trying to work off if it had not been for the sympathetic understanding of Professor Wallace Sabine. I remarked once to Mr. Lowell that I regretted never having studied history or government while I was an undergraduate. He replied that he could not see why I should feel that way about 


\section{Scientists and Philosophers}

it considering the variety of my reading since I left college. He added, however: "You wouldn't have made up your Greek and Latin that way." Of course he was entirely correct. I think Latin and Greek have to be drilled in as the foundation on which to build later studies of foreign languages. Although I can't read either of the ancient tongues at all fluently now, they help me make pleasant new generic names like Hoplophryne or Pomatops or Suillomeles.

During my Harvard years I have been asked a hundred times whether Louis or Alexander Agassiz was the greater man. The mere fact that I am the unworthy occupant of their chair does not necessarily make my opinion of value. Nevertheless, because I knew many of their pupils, and had the great privilege of knowing Alexander myself, I might reasonably be expected to have formed an opinion. But I was always noncommittal until one afternoon I had a long conversation on this subject with Mr. Lowell just a short time after he had resigned as President of Harvard College.

Mr. Lowell argued in this way: Both men had been interested in geology at one stage of their careers. Louis as a young man gave to the world his immortal studies of glaciation with all they implied. Glacial geology has now come to be a science by itself. The effect of the concept that there was a polar ice cap has had a bearing not only on modern interpretations of geology and oceanography, but on zoography and the modern interpretation of the distribution of plants as well. This work alone would have given Louis undying fame. Alexander's studies of coral 
reefs were carried on later in life, and resulted in the accumulation of an enormous number of data which have been useful, but he died without ever correlating and synthesizing his findings for the benefit of others. And therefore, Mr. Lowell concluded, Louis was the greater man.

Professor Stanley Gardiner conveyed more information as to the probable origin of atolls in the little bulletin published by the Museum in Cambridge than was contained in the many memoirs of Alexander Agassiz. No doubt Mr. Agassiz's untimely death kept him from completing his work, but the fact remains that he did not finish it. Both men were artists. Here, in my opinion, Alexander unquestionably excelled. Both did important work in embryology, and here again I think Alexander's work is superior. For one reason, it was done with more modern microscopic equipment than was available when his father did his work on the embryology of the turtles.

Both were really great taxonomists. Louis Agassiz's work on the fossil fishes stands to this day. His descriptions have never been excelled. The classifications have of necessity changed with the advance of knowledge, but his great volumes on the fossil fishes, written when he was a young man, are extraordinarily fine contributions to knowledge. Alexander's work on the sea urchins, of which group he was the world's authority, stands out with the same preeminent brilliance as his father's work on the fossil fishes. To this point I think we may truthfully say that both men have run neck and neck, with Louis a little in the lead, in that his geological work was far more impurtank. 


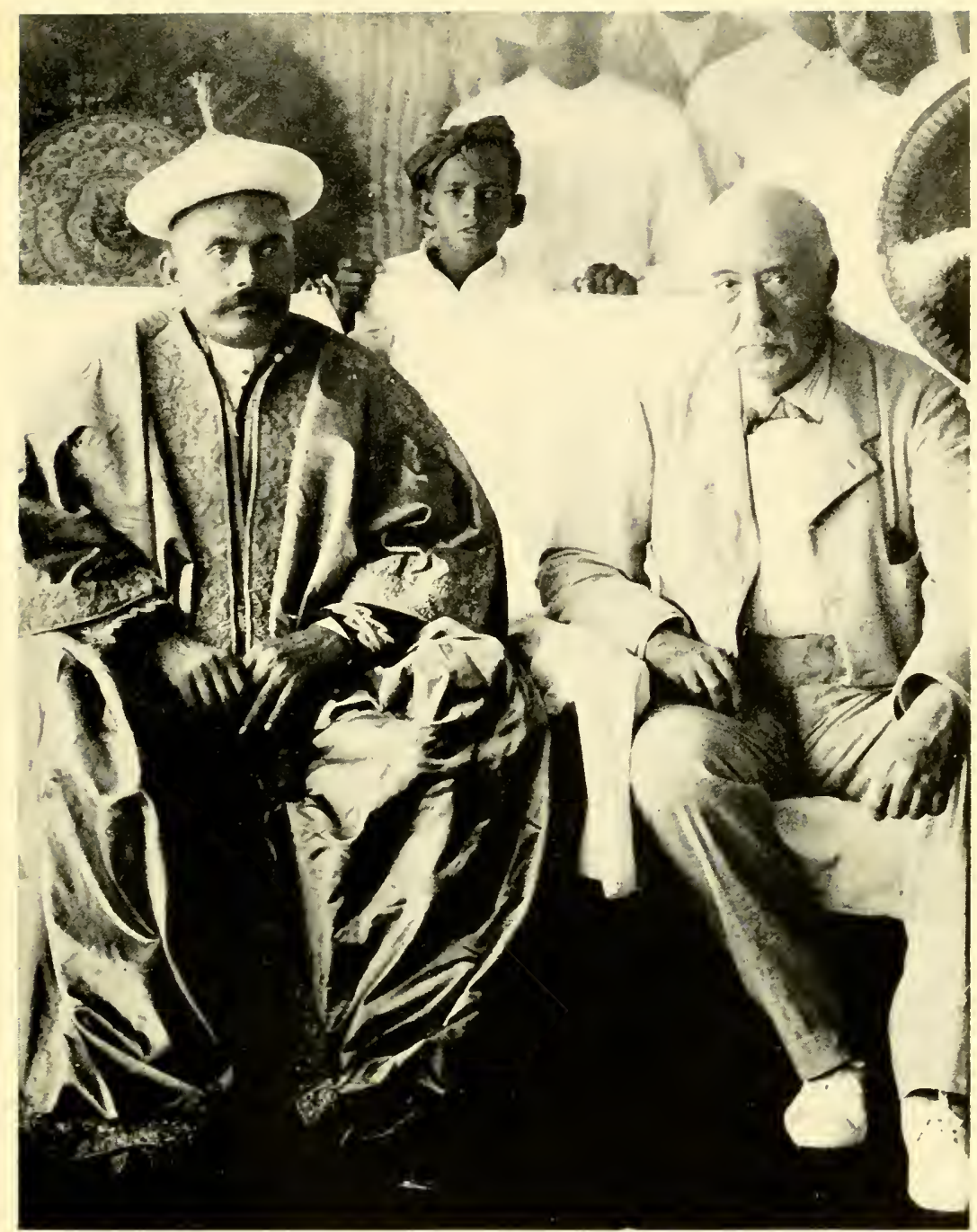

Photo by W. McM. Hooditorth

Alexander Agassiz and the Sultan of the Maldive Islands Aboard the "Amra," 1901 

From this point on, however, candor forces one to admit that Louis takes another great step in advance. He revolutionized the teaching of biology in America, and the effect of this was felt all over the world. Introducing laboratory methods to all classrooms of school and college was a real innovation, and his marvelous ability as a lecturer made him one of the most revered and popular geniuses in America. No other naturalist was ever known to so many people. None was ever so universally beloved. Alexander was too shy to teach, nor did he lecture well. As a matter of fact I think I heard him speak on only one occasion, and it was obvious he hated to do it just as much as I do. The tragic death of his lovely young wife but a few days after the death of his father had a deep effect upon his innermost nature, as any frightful grief affects a man. He had a quick, fiery temper, sharp likes and dislikes, but beneath his rather forbidding and stern exterior he had a warm, affectionate nature, and he was always kind and encouraging to young men. I recall that we brought back a strange sponge from our first very amateurish dredging trip in the Bahamas, and he took the greatest interest in helping me try to find its name, admiring its beauty and otherwise showing a friendly interest.

His father was no better businessman than I am. Alexander developed great mines, made money for himself and many others, and was unbelievably generous to the Museum. To be sure he was interested in some departments and neglected others. But who had a better right? Mr. W. E. Cory told me that he considered Mr. Agassiz very extravagant as a mine executive, but here again the proof of the pudding is that the Calumet \& Hecla Mining Company 
paid more millions in dividends than one likes to think of in these rather threadbare days.

I have tried to set forth my opinion realistically and fairly. As I have said, Mr. Lowell maintained that Louis Agassiz was the greater figure of the two. He was unquestionably correct in the final analysis, but both were very great men, and their like I do not meet now.

For years Uncle Bill Whecler and I projected a book on the contribution made to the study of natural history by amateurs. Then came his untimely death, and I have not thought again of the project until now. I received a few days ago with the compliments of the Carnegie Foundation a book entitled Tbe Amateur Scientist by W. Stephen Thomas. This sets forth in brief but fascinating form the contributions of the amateurs not only to biology but to physics, chemistry, astronomy, mathematics, and other disciplines in their widest sense. In biology alone think of the effect of the work of Darwin, in entomology of Sir John Lubbock, Henri Fabre, or of Lord Rothschild, in geology of Hugh Miller and Frank Buckland, in genetics of the monk Gregor Mendel.

In natural history no name stands forth more preeminently than that of the Reverend J. G. Wood, whose books have led children on to an interest in animal life for well over half a century. I can bear witness that they fascinated me as a youngster, and that I read and reread many of them until they were completely worn-out. Take the case of Gilbert White, for instance, whose Natural History of Selborne has been translated into many languages and appeared in numberless editions. Even herpetol- 


\section{Scientists and Philosophers}

ogy, which generally speaking has not been popular among amateurs of natural history, had its champion in Dr. J. E. Holbrook of Charleston, South Carolina, whose American Herpetology is a classic to this day.

While this list is by no means to be despised, and while it would be hard to match what it has meant to the world with an equal number of names of college professors, it becomes infinitely more impressive if we add a few names drawn from other fields. Isaac Newton was a government clerk. Leeuwenhoek, the father of microscopy, was a Dutch merchant. Joseph Priestley, always thought of as a chemist, was in reality a parson. Sir Frederick William Herschel was an organist, and an astronomer and mathematician only on the side, so to speak.

I have given in barest outline what Wheeler and I often talked over in the Eateria, for we lunched together 1087 times after we began to keep the record of the Eateria January I, I930. Of course, there are others, like Benjamin Franklin, of equal fame and many more whom we spoke of that I do not recall. The whole matter has lain completely dormant in my mind for a number of years. Stephen Thomas has made an excellent book and recalled these pleasant conversations with Wheeler. The subject is a fascinating one not only in the recording of what the amateur has done in the past, but in stimulating speculation of what the future may bring forth.

I wrote to my friend Henry James asking whom I should thank for having sent me Mr. Thomas's book. He answered giving me the information desired, and continued with an observation which I think is well worthy of record. He wrote: - 
When I was on the Board of Overseers, I was pretty constantly on Visiting Committees that visited botanical and biological departments, and I got very much interested in a fact, as to which I worked up a lot of figures, for a report to the Overseers, viz., that the graduate students in biology are on the whole not graduates of Harvard College. The undergraduates who take much biology at Harvard don't pursue the subject except at the Medical School or elsewhere. And the implications and explanations of this, to you, perfectly familiar fact seemed to me quite interesting. What used to be called Natural History ought to be one of the best cultural studies. A man who cannot use his eyes and ears as he goes about in his physical environment and cannot learn about the universe except by digging himself into the stacks of the Widener Library and putting on a pair of spectacles is only half a man. But for some strange reason two generations of scientists have chosen to treat amateur naturalists as triflers, the systematist as a pedant; and the school teachers have failed pretty completely to do much with natural science. Crazy and deplorable!!

This is something which Howard Parker has also often spoken about. He has remarked on many occasions how few of his colleagues teaching biology in Cambridge are graduates of Harvard College. Robert Jackson was until he retired. Henry Bigelow, Jeffries Wyman, and I are the only three on the present staff if I mistake not. 


\section{$P A R T 111$}

\section{THE LEISURELY NATURALIST}





\section{CHAPTER XIX}

\section{Florida and Some Snakes}

URING and after the last war the family lived in Palm Beach - a less sophisticated Palm Beach than that of today. Some months after the Armistice, when I finished the office work in Cuba, I spent a lot of time hunting and fishing in Florida with Frank Carlyle. Frank was much more than a guide, for I needed no guide in that part of the world. He was an ideal companion, an amazing shot, a born naturalist, and he had a homing sense which was uncanny. It was nothing to walk in the pinewoods for hours and then, feeling hungry, to suggest, "Frank, let's go to camp." And we would walk straight off, with Frank in the lead, and pretty soon there would be the old Model $\mathrm{T}$ beachwagon and our tent. Frank was a good cook, too, and his quail and doves cooked with rice were succulent beyond belief.

One day we put up a big flock of turkey which flew into a high strand of cypresses. It was too near dark to do anything with them, so on Frank's suggestion we turned in. About midnight he got up, went to town, and came back with a live hen turkey which he said he had borrowed. We went to where we thought our wild birds might be likely to fly down and tethered our hen by a long string to a young pine tree. Then we went off and hid. The sun came up hot and clear. We sat about, but something happened and we heard no yelps to indicate the approach of our wild birds. Before long we stretched out on the sand and were 
fast asleep. We dozed for perhaps an hour until we were suddenly awakened by the crack of a gun. We sat up to see the most surprised Seminole Indian any living man ever beheld. He had shot our tethered hen. We asked him to lunch, but he walked off in disgust. He made no move, however, to indicate that he thought the bird was his.

We never hesitated to camp and to leave our things lying about if the spot we had chosen was near an Indian village or one of their temporary encampments. Crackers would sometimes steal, Indians never - at least, not in our experience. I inadvertently used the word "cracker" then. Everyone knows that the native sons of Georgia and Florida are called by this name, but it was not until I stumbled on a simple statement in Bartram's Travels that I knew the derivation of the term. The corn crackers are those people who sincerely enjoy that delectable viand, grits and gravy; for grits, you know, are made of cracked corn.

My father- and mother-in-law frequently joined us in our camp for the day. Mr. Dean Pierce was almost blind but was able to fish with real enjoyment. Mrs. Pierce, the loveliest mother-in-law any man ever had, would sit in a Livingstone chair in a shady place and sew or knit and enjoy the warmth and the spring songs of the birds. One day Mr. Pierce, Frank, and I were fishing in the canal which had just been made, running from West Palm Beach to Canal Point on Lake Okeechobee. When the canal was first dug and its banks had not begun to wash down, the water was deep and the bass fishing excellent.

One day I saw the corner of what I knew was an elephant's tooth sticking out of the canal bank, just at water level. I asked Frank to row over to it, and I dug the tooth 
free with my fingers, for it was buried in soft sand. Frank was utterly mystified; declared there had never been any circus near enough to suppose a dead elephant might have been buried where we were. I kept the spot in mind, however, and some years afterwards went back while visiting Charles and Louise Choate at Palm Beach. I got a good many interesting bones of a perfectly gigantic elephant and fragments of some other things as well, but after a month or more of steady digging it was quite obvious that the best of the material had been smashed up and dispersed in the process of digging the canal. This was a bitter disappointment.

I have a shoulder blade of this elephant here in the Museum on exhibition now. I showed it to Dr. Forster Cooper, Director of the British Museum, when he last visited us. He said that beyond question it represented the largest individual elephant that he had ever seen, and he was widely experienced. The shoulder blade of a fair-sized mastodon which is mounted in our Museum is literally only about 60 per cent in height or area compared to our Palm Beach giant. I have just measured our mastodon, which stands about $8^{\prime} 3^{\prime \prime}$ at the withers, probably $8^{\prime} 8^{\prime \prime}$ or $9^{\prime \prime}$ in life, whereas the shoulder blade from Palm Beach, assuming the proportions are more or less those of the mastodon, which they were not, for we know the Florida elephant was much longer-legged in proportion, indicates an animal $13^{\prime} 10^{\prime \prime}$ high, and probably considerably more. There is an enormous elephant in the Amherst College Museum which Dr. Loomis bought from C. P. Singleton, who dug it up at Melbourne, Florida, only a few miles from Grandmother's old home. This is a huge animal, but not 
so big as the one I might have found with better luck. As a matter of fact, I should have had the one that Loomis got if I had heard of its existence just a little sooner.

I traveled for years with a wonderful companion, Winthrop Sprague Brooks. He was a talented naturalist who, unfortunately, did not see fit to continue work in the field of zoology. We were together in Florida on many occasions and frequently collected around the Royal Palm Hammock in the very southern tip of the state.

It was when the hard black roads were first put in and before the snakes which crawled out to warm themselves on particularly cool nights had been largely exterminated by motor travel as they have been now. This has happened to countless thousands upon thousands of reptiles. Indeed, like Professor Shaler, I once made a computation to prove this point. Fairchild and I, crossing on the road from Miami to Everglades - it was in the very early morning - got out to look at some birds. As far as one could see down the road there were little patches which reflected the rising sun's rays. Upon examination we found that each one of these was a remnant of a snake, mostly ground and polished bits of skin of young water moccasins. We measured the width of the road and counted the number of remnants in a distance of about one hundred yards and thus figured out the probable slaughter along the eighty miles from Miami to Ochopee. I have lost the slip of paper with our figuring but the number was absolutely unbelievable.

Well, this sort of thing was happening in a minor way when Brooks and I were at the Royal Palm Hammock. I had seen several remnants in too bad shape to save as a 
specimen of what I was certain was a new king snake. Finally I got a beautiful specimen. I had nothing to put it in at the time I caught it but a stiff paper bag, which I carried back to Palm Beach and set down in our bedroom. It was late in the evening and I did nothing about preserving the specimen that night. When I woke up the next morning, lo and behold the bag was empty. We pulled the room apart without finding our snake. I overlooked until later a rat hole under one of the doors. But we found out where the snake was before very long, for wild cries from the kitchen took me out there on the run. The snake, about five feet long, was neatly coiled up next the hot-water boiler, apparently entirely satisfied with life.

This snake is now M. C. Z. number 12,456 and is the type of Lampropeltis brooksi, named for my friend.

I believe a hundred years from now there is one thing that conchologists are certain to say - "It was a darn good thing old T. B. got interested in Ligs when he did." Ligs, be it known, are the tree snails of the genus Liguus. Their distribution is strictly limited to parts of Cuba, Isle of Pines, Haiti, the Florida Keys, and the extreme southern part of the peninsula of Florida itself. Moreover, in Florida they are not generally distributed. They are only associated with certain types of trees which grow in those enigmatical plant associations known as hammocks.

The origin of these tiny islands of tropical broad-leaved trees scattered about in the pine lands is very difficult to explain, but the fact remains that once there were many of these hammocks scattered over south Florida and a few in the Keys. The very fact of their existence is proof of the 
presence of good soil. Years ago it became clear to me that the hammocks were going to be cut over for plantations and the snails would disappear. In fact, way back when I was a boy I observed "Saws," as the Negroes from the Bahamas are called down in the Miami area, using long bamboos to knock the snails out of the trees of the Great Brickell Hammock. They used them for fish bait.

I made up my mind to get a representation of the snails from every hammock within the limits of their distribution, roughly from south of a line drawn from Fort Lauderdale westward across the state. When I started out, our collection of these marvelously beautiful creatures was but a few hundred, whereas today we have 43,235 individuals in the collection from 490 localities, representing 65 named forms, with 48 types. For anyone with an eye for beauty, it is a joy to collect Ligs. The whole group of shells is in a state of flux, evolutionarily speaking, and there are over 60 color varieties. Some are pure white with pink stripes, some white with green, some exactly like tortoise shell, some pure white, varying also in size and form. These creatures indeed are so beautiful that a cult of Liguus collectors has come into being and thousands of specimens have been gathered up with no record whence they came. These are now reposing in the hands of people who do not appreciate the story that they could tell if complete data had been kept when they were gathered. Ligs have disappeared from many localities where they were once abundant and I take satisfaction in the fact that before they disappeared we got the best collection of Liguus in the world. And none better will ever be made. 
A fishing trip to Everglades has been an annual feature of my visits with the Fairchilds at Coconut Grove. We have had the same boatman for years and, by planning far enough ahead, I have usually been able to get the same cottage for a few days' stay. The chance to visit this strange labyrinth of waterways, which comprises the deltas of half a dozen rivers emptying into the Bay of Ten Thousand Islands, has been fascinating because there have always been botanists involved. First, of course, there has been David Fairchild himself, though he was not present the day John Phillips was with me and we saw a big panther walk across an open glade in the mangrove forest.

Of our Museum crowd, Ted White and Barbara and William Schevill know this country and helped to get an interesting lot of mammals, particularly raccoons. Years ago, E. W. Nelson showed that the raccoons of south Florida broke up into a lot of races, which he named. I was doubtful whether these races would stand up when long series of the animals were compared. As raccoons are extremely abundant in the forests around Everglades, we made up a test series to see how much variation was shown among the individuals and found there was practically none. Nelson was right.

My friends Harold and Sis Loomis with their Margie and Jim have often been most delightful and co-operative companions. They love to fish and they do not think I am crazy because I frequently sit back for hours at a time and just look into the woods as we troll slowly by. Last year Professor Elmer D. Merrill, the distinguished Director of the Arnold Arboretum - Elmira to me, though I do not know exactly why - was along, and I felt a patriotic thrill 
when he declared that the formation of shore plants in the mangrove area was as fine in their majestic size as anything in the Philippines, although, of course, infinitely less varied in the number of species of trees.

During the last few years a good part of my time has been enjoyably and profitably expended in watching the excavation at the Thomas Farm in Gilchrist County, Florida. Years ago on a visit to the Museum of the Geological Survey in Tallahassee I saw the fragmentary fossils which Clarence Simpson found in I93 I and which were sent to the American Museum in New York for description. Some years passed by, and by 1938 it was quite obvious that with the Florida Survey being forced to specialize on economic geology, there was no likelihood that anyone was going to take an interest in the Thomas Farm locality. I decided to explore the locality thoroughly. Herman Gunter and Clarence Simpson of the Survey gave me every assistance, marked maps and made sketches. Finally, with some difficulty, because there are numberless "Thomas Farms" in our county, the Raeford Thomas Farm was located in the scrub about eight miles northeast of Bell. A further difficulty was that all the dim roads in the scrub change from year to year, as ruts get too deep and new routes are found.

Gilchrist County is self-contained. Strangers do not come there, and the residents are suspicious of anyone who comes in from even a few miles away. With the aid of William and Barbara Schevill, who were my companions several years ago, we began to dig at the abandoned farm site. There were the remains of the old well, and it was on the spoil bank beside this well that Clarence Simpson found 
the horse teeth which were the first indications that there were Miocene mammals to be found here. He certainly deserves the greatest credit for his instantaneous appreciation of the importance of this site.

Deposits of Miocene Age throughout eastern North America are generally of marine origin. In the West they are abundantly developed and exposed in the Badlands, where an unbelievable number of vertebrate fossils have been found. Before we dug at the Thomas Farm we had no picture of Miocene life on land in the Eastern United States that was of anything but the most fragmentary sort.

By extreme good fortune we enlisted two extraordinary helpers. Uncle Frank Douglas and John Henry Miller were characters that might have stepped from the pages of The Yearling. In spite of the fact that we were strangers, hence very unwelcome in a region abounding in moonshine stills and where one of our near neighbors was a murderer who had left a neighboring state for excellent reasons, we became and are fast friends. John Henry and Uncle Frank can take out a badly crushed rhino skull and "make a biscuit of it," as we say, cutting down around it until it stands on top of a pinnacle, and plastering it up with strips of burlap soaked in thin plaster of Paris. Then, after this covering is hard, they undercut the fossil and turn it over, then plaster it up on the bottom side.

From a little hole our dig has grown until now you could put a big house in the excavation. And the end is not yet, for while we have taken out 18 genera and 22 species of mammals, most of them undescribed and many of them curious and bizarre, we have indications that there are at 
least as many more represented by fragments too incomplete to stand as types of described species.

After suffering a good deal of amateur blackmail and threats of violence from a neighbor who claimed to have a lease on the abandoned farm, we finally found that it was owned by a bank in Macon, Georgia, which had taken it by foreclosure many, many years before. I bought the forty acres around the dig, and now have deeded them to the University of Florida, which is located at Gainesville only forty-five miles away.

The digging is finished for the time being, and we have built John Henry Miller a little house there of an architecture typical of the country. Our house has a room at one end for a kitchen, a "breezeway" in the middle, and a room beyond the breezeway in which to sleep. John Henry has planted wild verbena around the yard, and our friends Archie and Margie Carr, of the Department of Biology at the University, have brought out bulbs and seeds. During the last year when I have been rather on the feeble side with a nervous and irritable heart, I could sit in the shade and watch the butterflies visit the flowers in the yard, listen to the earthy Elizabethan speech of my friends digging near at hand, and look forward each day to a cornpone, side meat, and collard greens, or a gopher-turtle stew prepared by John Henry's master hand.

From small beginnings the Thomas Farm has grown so that now it is the most important and most famous vertebrate fossil locality in the Eastern United States, and I have a hunch that a generation hence scientists are going to say that spotting and opening the Thomas Farm dig was a good job. 
Before Dr. T. E. White went to the Army, he left a manuscript concerning the finds at the Thomas Farm. Since he is a specialist in the study of fossil mammals, I can give a better outline of the material which has been excavated than I could do with my own knowledge unaided.

The high lights were the discovery that no less than five species of little three-toed horses apparently lived in this part of the world at the same time. These varied in size from that of a collie dog to that of a Shetland pony - a small pony. The situation must have been somewhat similar to that on the Athi Plains in East Africa where one may see Impallah, Thompson, and Roberts gazelles all mixed up together in great herds. They are just about as different, one from the other, as these little horses were. Of course the fact that these fossil remains, disassociated and redeposited, have been water-borne from the place where they were first laid down may well mean that they are not strictly contemporaneous - but that we can't tell about now.

There were two types of rhinos, a small one and an enormous, long-legged beast which must have been an impressive animal to see.

There were also an unusual number of doglike animals, some the size of coyotes, and others at least as large as the grizzly bear. There is very little evidence of the presence of any feline forms but most astonishing of all are the two genera of an extinct group of mammals called the Hypertragulids. These are relatives of our deer but they have skulls so elongated that I once facetiously described one of them as a hoofed anteater. It is difficult to imagine what specialized feeding habits may be tied up with this peculiar 
head form. It is not unlikely that the skull was modified for probing for and picking up aquatic vegetation.

Most tantalizing of all the vast quantity of material which has been brought to Cambridge and sorted out are the remnants which prove that there are at least twelve more animals represented by fragmentary bits, too incomplete to make certain of their identity; hence at least there are twelve more forms to encourage one to dig further, and of course there may be a great many more than twelve.

Shortly after the First World War Lord William Percy came to spend a week end with us in Palm Beach. He ended by staying well over a month and certainly he was a fascinating companion. A short, spare man with keen aquiline features, he started as a brilliant barrister in London, rose to be a Colonel with the Grenadier Guards in the war, was badly wounded, and had been decorated with the D.S.O. Now he was seeking refreshment in his avocation, which was ornithology. He was particularly interested in the successions of plumage in our many species of ducks.

Our Florida dusky ducks fascinated him. He was a wonderful shot and rapidly made up a superb series of specimens. He was keen to find out something of the habits of the little secretive masked duck, a bird which is widely distributed but which has been very rare in collections. I knew a place in Cuba where they were said to be found and we sailed off to see if I had the story correctly. My friend Mr. Carlos ("Charlie") Hernandez was then Postmaster General of the Island, and we joined forces with his brother and camped in a big, aromatic tobacco barn - it was only partially filled - near San Antonio de los Baños. 


\section{Florida and Some Snakes}

Near-by Lake Ariguanabo was, as it always is during the dry season, a great sea of "bonnets" or malanguetas as these leaves are called in Spanish. I like the name "bonnet," for it is descriptive of those stiff, curled-up, water-lily leaves in which little yellow rails frequently hide and over which the sharp-eyed grackles continuously creep about seeking out the bonnet worms which bore into the stems. The lake is variable in size, covering several hundred acres during the rainy season.

Native hunters appeared when the grapevine telegraph got working and I asked them about getting for us specimens of the pato agostero, as the masked duck is locally named. They replied that this was easy but that shooting would have to be done at dawn when there was no breeze to move the bonnets. This mystified us a bit at first but we found afterwards that the natives push a little cockleshell about, standing up and watching the bonnets. When they surprise a duck it dives, swims off with just its bill stuck up above the surface of the water, and, of course, rustling the bonnets a bit as it swims away. Now the extraordinary fact is that these men are never fooled by turtles, which, when disturbed, rush off stirring the bonnets also, for the men know the rate of speed of turtle and duck. By shooting just ahead of the quaking leaves moved by the ducks, they get pretty nearly every individual they shoot at. They soon brought us all the ducks that Percy wanted.

Ruddy ducks were present in the same lake and, of course were often killed as well as the masked ducks. Their habits are very similar. When either of these birds came to rest it was almost always among the malanguetas. The name agostero or August duck is derived from a reputed 
nesting in August and the fact that it is apparently more abundant at that time. I suspect that this simply means there was more open water then and so both masked ducks and ruddy ducks were seen more frequently.

I asked Percy to transcribe the notes which he had made during our Cuban trip. He answered: -

According to local information, the masked ducks are much less secretive in late summer and autumn when the lake is higher and provides less cover from view; in such conditions we were told that the masked ducks flew a good deal of their own accord, especially early and late in the day, and experience elsewhere with these birds did not suggest that they were difficult to flush, though they rarely flew farther than the nearest patch of cover. On the other hand local hunters agreed that, while the masked ducks took to wing quite frequently, the ruddy ducks never did so under any circumstances. This, if true, is remarkable, but it is possible that the Cuban race, being entirely stationary, may have developed a more skulking habit than that of the migratory race in Canada and the United States. (It certainly is a fact that the Erismaturas of the high Andean lakes are so unwilling to fly as to give an impression of incapacity to do so, for during several consecutive months of constant association with them I never saw one on the wing, although we frequently tried to induce them to fly.)

In Cuba the ruddy ducks were in full breeding dress on the thirtieth of January $192 \mathrm{I}$, and were actually breeding on that date, whereas the male masked ducks 
were in full moult and young birds were obtained which appeared to be from four to five months old. We were told that this bird bred in August and was locally known as Agostero for that reason.

The call of the male masked duck is very distinctive, "kirri-kirroo, kirri kirroo, kirroo, kirroo, kirroo," and the bird has a curious habit of responding like a cock pheasant to such noises as the banging of a punt pole on the water or an explosion in the distance. The female makes a short hissing noise, repeated several times.

No firsthand information was collected with regard to these birds' nesting habits, but a local hunter pointed out several nests which he said were those of masked ducks. According to him, the nests were always placed amongst short, round rushes, and contained from five to six eggs but never any down at all.

After his return to England Will Percy and I corresponded in a desultory way. Once I went to visit him at Catfield Hall, near Great Yarmouth, motoring over from Cambridge. This was after his marriage. For in July 1922 he wrote me: -

\section{Dear ToM:}

I'm too busy to write, and too happy to do so coherently. I am going to get married on 25 th July to Miss Mary Swinton with whose family mine has swapped for nearly rooo years. Poor girl - she gets a bad bargain in marrying a worn-out fossil of forty (she being 23) but she is bearing up wonderfully. 
Now heaven knows what I do - take the first job anywhere on the earth's surface at which I can earn enough to keep her in comfort.

Later he came to London to see Rosamond and me. I am sorry to say I have not heard from him for a long time. I know his section of England has been terribly bombed. Every member of our family missed him after he left Florida to go on to Panama and South America, ducking his way for months till he finally got back to England. He never wrote up his observations, for John Phillips had his monograph far advanced and Percy generously contributed many observations which enhanced the value of John's book. His collection is now in the American Museum in New York. He is a great gentleman, a gallant soldier, and a true scientist at heart. 


\section{CHAPTER XX \\ The Tests of Evolution}

I

THINK there is more misunderstanding about evolution among laymen than about any other subject. Of course we know that some fundamentalists still deny it. I am not writing for them, but rather for those who have been led to believe that the whole subject is settled and that "scientists know all about it," which is quite untrue. The results of evolutionary processes are everywhere easy to see, but the situation is really like that of the man who sees a trolley car for the first time. The route it has followed and the direction in which it is going are clearly to be seen, and the rate at which it progresses is obvious. But what makes the thing move?

Take such a stock as that of the horse, where the fossil evidence is unusually good. Practically every single gradation from the little fox-terrier-like animal of thirty million years ago to the present-day horse may be followed with infinite elaboration of detail. The horse had its origin in the New World and we know when it moved from the New World to the Old, where it persisted in the form of the zebras, wild asses, and wild horses of Tibet. The skeletal remains show that horses, as we use the word today, existed in Florida down to perhaps 10,0oo years ago in unbelievable numbers. Then they died out. Why they died out remains a mystery. The Spaniards brought horses with them from 
Europe and enlarged them - that is, turned them loose and in no time they became enormously abundant again.

Few laymen know that the camels originated in America and went through most of their evolutionary history in what is now the western part of the United States. During the height of the glacial period enough oceanic water was tied up in the gigantic polar icecap to lower the level of the oceans, so that many land areas now separated by water were then connected. Thus the camels reached the Old World and the elephants reached the New; and strangely enough, according to a Russian scholar, Nazonoff by name, the sheep not only passed from Asia to North America but went back again, leaving the ancestors of all our various species of bighorn behind them.

Geologically speaking, a fairly recent uplift of land formed Central America (for the Caribbean Sea was once a bay of the Pacific) and allowed camels to reach South America, where they persist as the llama, alpaca, guanaco, and vicuña. The stock then died out in North America. The elephants pushed down as far as Ecuador and likewise disappeared, as they did all over North America, where they once existed in countless numbers of individuals and a great variety of species.

I can hear my reader ask, "How do you know that the Caribbean was once a bay of the Pacific?" The answer was given by Alexander Agassiz during his explorations with the steamship Blake. He found that there was a greater difference between the deep-water fauna on the inside and that on the outside of the arc of Lesser Antillean islands than there was between the fauna inside the arc and that on the Pacific side of the Isthmus of Panama. Only last 
year I described a lovely rosy Chaunax, a chubby, potbellied deep-sea fish which had its only near ally in one described from the Bay of Panama, and my fish came from the south coast of Cuba in a thousand fathoms of water.

Unfortunately the lines, "Some call it Evolution, And others call it God," however true they may be, savor of the trite and the smug. No one who thinks and has had a real chance to study modern paleontological material doubts the fact of evolution, but the mystery behind it all is deep and dark and as worthy of our worship, if you will, as it ever was. Scientists have seen the evidence where evolution has run riot. The dinosaurs reached a size which was mechanically disadvantageous. The Irish elk proceeded to produce such gigantic horns (which presumably were dropped each year) that their very renovation from year to year must have involved a fatal weakening of the stock, which of course has long since disappeared. Cope had a phrase for this process, and a good one, too. It was "superabundant growth force" - growth in a particular direction until it becomes lethal.

But what brings this force into being? Darwin provided a couple of useful slogans - "sexual selection," "the struggle for existence," and Spencer added "the survival of the fittest."

Each one of these explains a good deal. But let us apply it, for instance, to the leaf butterfly and see just how much it helps us. Metaphorically speaking, a racial stock of butterflies for its own protection starts out to become deadleaf-like. If this change were to be accomplished by natural selection alone, it would be reasonable to suppose that as 
soon as the butterflies became sufficiently leaf-like to be protected the evolution would cease. It did no such thing. The leaf butterflies of the Old World are decorated with marks such as the fungi of decay produce on dead leaves, and have ragged wing margins which look like wearings or tearings in some cases. In other words, they have become ridiculously and unnecessarily dead-leaf-like. Something pushed the evolutionary urge along far beyond necessity.

Lamarck postulated the evolutionary power of use and disuse and believed that acquired characters might be inherited. We all know, however, that certain sections of the human race have mutilated themselves for thousands of generations without result, and we know that in the old days when horses' tails were regularly cut short, no shorttailed colts ever appeared.

As a matter of fact, to be realistic in our appreciation of evolution we have to be willing to say, "I don't know how or why, but it is there just the same." We have to avoid believing in what may seem to be too obvious. Consider how fearful the ordinary person is of inbreeding. Such and such animals are inbred; hence they are weak, stupid, deformed, or what have you. As a matter of fact, animals may be successfully bred for countless generations, brother to sister, if nothing but completely sound stock is used to breed from. Of course one abnormal individual may upset the strain and bad results will then appear, but the bad results do not come from the inbreeding.

I have recently been studying a group of fishing frogs, deep-sea fishes in which the first element of the dorsal fin has been developed into a fishing rod. In some of the fish 


\section{The Tests of Evolution}

this is capable of motion and may be moved out in front of the fish's mouth and waved to and fro, the tip of the ray being beset with little movable filaments which are fished about, squirming like a worm on a hook, to lure small fish up and into the mouth of the Antennarius.

This group of fishes is enormous, and in some species we see all sorts of ridiculous things which have happened - cases where a rod persists as only a useless filament incapable of motion; cases where it is elaborated into an organ so complicated and so absurd that it is hard to believe that it is anything but an ornament, using the word in its zoological sense. The creature couldn't possibly get that great branching affair into its mouth. Some of these fishing frogs are just gigantic muscular sacs with fins so degenerated that obviously the creatures cannot move. They have great cavern-like mouths, not improbably suffused with a luminous slime to lure fish to a point where, with a sudden gulp, they can be engulfed by these animated muscular sacs.

Many of the baits at the end of the fishing rods are luminous, and some rods are long enough so that this luminous bait can be pushed right around and into the fish's mouth. Then he snaps on the electric light, the little fish come up inquisitively, he snaps it out of the way, the mouth closes, and our fishing frog is fed.

I cite the extraordinary example of evolution presented by the fishing frogs because to me it is absolutely impossible to see how the first step ever happened to take place; it is simply not explainable by any means at our command. The fishing rod had to be a good fishing rod before it 
served the fish any useful purpose at all. Now explain that if you can.

This discussion may sound a little old-fashioned to a modern specialist. Recent authors, among them Richard Benedikt Goldschmidt of the University of California and Ernst Mayr of the American Museum of New York, have written fascinating books concerning the modern interpretation of micro- and macro-evolution. The light which modern genetics has thrown on evolution has been carefully appraised; moreover, what it may be expected to interpret in the future has not been neglected. Genetics has thrown light, and a flood of light, on heredity and the mechanism of inheritance.

This is a very different thing from throwing light on transformism, which is evolution. Mayr has shown that the systematic zoologists, or the taxonomists, with, of course, the paleontologists, are the ones who have made the most extensive contributions to our knowledge. Whether they will continue to do so in the future remains to be seen.

But the sum total of what is really new is not greater than the contribution to knowledge made by Hugo de Vries in I90I, and nothing like so illuminating as the restatement of Jordan's Law of Evolution through Isolation - which I am about to quote in the words of Tate Regan. $\mathrm{He}$ has pointed out in these meaty paragraphs that this isolation might be geographic or habitudinal: -

This theory [that is, the mutation theory], which explains adaptation as the result of a series of fortunate accidents, appears to me to approximate to the old "special creation" theory, and it was in opposing this 
idea of great and sudden transformations that Darwin wrote: "To admit all this is, as it seems to me, to enter into the realms of miracle and to leave those of science." The mutation theory is in favour with the geneticists, who have found that definite variations occur and are definitely inherited. But the geneticists are puzzled to suggest how these variations could become specific characters, common to all the members of a species, seeing that they are not adaptive, and therefore could not be selected.

Systematists attach little importance to interspecific sterility; they know that Darwin showed that between allied species there are all gradations, from complete sterility to complete fertility. But for the geneticists sterility is all-important - it is their one hope of producing the semblance of a species - and they proclaim that the event for which they are waiting is the production of a variety which is sterile with the parent form. That great event, if and when it occurs, will leave me cold; in my opinion, it will have about as much relation to the orgin of species as the occurrence of albinos has to the coloration of arctic animals - that is to say, no relation whatever!

My own work on the structure, classification, and geographical distribution of fishes has led me to certain conclusions. I believe that the first step in the origin of a new species is not a change of structure, but the formation of a community, either through localization, geographical isolation, or habitudinal segregation. I also think that specific characters may be grouped as follows: they are either $(a)$ useful, $(b)$ 
correlated with useful characters, $(c)$ due to the environment, or $(d)$ the expression of some physiological peculiarity. But I see no reason for believing that they have originated as mutations.

As I said before, we encounter a multitude of mysteries in the study of evolution, and these have made me a little bit impatient and uncharitable toward the atheist. As man's knowledge of the mysteries expands, their magnitude increases and leaves the honest and candid man very humble in mind.

I don't see why anyone should gag at the cousinship of man and the apes - the relationship is too distant. Rather let him consider with awe the majesty of orderliness which to the humble-minded is the subject most to be respected within man's ken. Like the concept of infinity in time or space, this matter passes our understanding. 


\section{CHAPTER XXI}

\section{Whales}

F OR a student primarily of reptiles I have had a singular number of opportunities to add interesting species of whales to the collection of the Museum.

The first occasion was in my twenty-third year when I read in a local paper that a small whale had come ashore at North Long Branch, New Jersey. My family were spending the summer at Monmouth Beach that year and I purchased a large butcher knife and walked to North Long Branch. I found that the little whale was being exhibited and that its owner would continue in this way to capitalize his find until the Board of Health intervened. The Board did intervene a few days later and I proceeded, having had the whale photographed, to cut off its head. I wanted to rough out the whole skeleton, but cutting off the head was a fearful ordeal and I got myself covered with such stinking gurry that I was ashamed to enter the house when I got home. I packed the skull in a barrel with salt and ice and shipped it to the Museum in Cambridge. When I got back to Cambridge I asked where it was and was gruffly told by my superior that it had been sent to the North Cambridge dump. I went up there and by great good luck found it, although it had been somewhat damaged by dogs. Nevertheless, enough remained for my friend, Dr. Glover Allen, to write an important paper on the find - for the species represented was a very rare one. 
My next adventure came a few years later during a Christmas vacation when I was in Banana Creek near Cape Canaveral. I was fishing with Dr. Charles G. Weld in his launch when we came on a porpoise that had got into shallow water. We killed it with a shotgun. I have the tanned skin and skull of that beast in the Museum still. We both tried it for breakfast, but it tasted like cotton waste soaked in cod-liver oil. Not even the liver was to our minds in the least edible.

The next chance to collect cetaceans that were really useful in the Museum came right at Beverly Farms when two beaked whales chasing fish on a falling tide got stranded quite near where we live in summer. Their uncannily human groans, deep sobbing sounds, were audible half a mile away, and had kept the neighbors uneasily awake. A local fisherman came along before I did, made them fast with ropes to trees on the shore, and carved his initials on their hides, thus under Massachusetts laws making them his own. He neglected to do anything with them for several days, however, and I got authority from the Board of Health to take them over. I got a tug and towed them to Ten Pound Island in Gloucester Harbor. There, with the advice of my friend Mr. William McGinnes, then Mayor of Gloucester, and with the help of some fishermen whom he knew, we cut each whale into two pieces - no small task, for these were big animals, eighteen to twenty feet long. Luckily there was a tug in Gloucester Harbor that had a powerful crane on board. Thus we were able to pick up the pieces, load them into trucks, and take them to a rendering plant in Danvers. In this way it was possible to save both skeletons complete and these we have in the 
Museum. I may add that, here again, this whale adventure was odoriferous in the extreme.

Now to Virginia Beach in the autumn of 1938 . I walked to get the mail, from our house at the Sand Bridge Club. The mailman drove down the beach every other day, leaving our mail in a box on top of a high post. Walking about and waiting for the mailman's arrival, I saw a black object near the surf. It was a pygmy sperm whale. This was small enough so that we could haul it right to the Club House, ice it, and send it to Cambridge. It had a deep cut across the back of its neck. I am quite sure it was killed by getting too near the propeller of a steamer.

The next year, almost to a day, I walked down the same road with my young friends Barbara and William Schevill and was telling them about finding the little whale. We had no sooner reached the mailbox than I saw a black object in about the same position and then, looking down the beach, saw another. Since one of these individuals, which both turned out to be pygmy sperm whales, was obviously immature, we concentrated on the adult specimen, which we found was a lactating female with an embryo about a foot long in her uterus. Both of these whales had been killed by a sharp cut across the back of the head in exactly the same way as the one we found the previous year. After finding these two little whales, it suddenly occurred to me that just the day before from the top of a near-by sand dune I had watched the southward passage of a large flotilla of torpedo boats which had passed out from the Virginia Capes southward bound. I suspect it was one of these that killed them. 
Thus we know that this rare little solitary whale, which has turned up here and there all over the world (our only previous specimen in this Museum was from New Zealand), evidently has a way of following behind ships instead of preceding them as is the usual practice for playing dolphins. Moreover, evidently the young of the previous year follows the mother and continues to suckle until the young of the next generation is a well-grown embryo.

The last of these events I am going to describe in my daughter Julia's own terms: -

Mother, my sister Louisa, $\mathrm{Pa}$ and I were in Virginia for our annual bout of duck shooting. On this particular occasion we were shooting some beach blinds owned by our cousin whose property adjoins our Sand Bridge marsh. To get to Barbour's Hill (a seventeen-foot elevation above sea level) one drives about eight miles along the beach. This in itself is a treacherous pastime at best and not made any less so by our vehicle - an old station wagon whose superstructure is rusted away and whose brakes and lights have long since departed.

We had an excellent time at Barbour's Hill, wangled our limit in geese and ducks and started home. The beach buggy was laden down with our loot and ourselves. We proceeded slowly, careful to avoid the stumps of petrified trees and ribs of wrecked sailing ships. Occasionally a marsh hog would eye us over the edge of a sand dune and then run hastily away. We must have been a terrifying sight. The sea was quite rough and waves rolled in fast - breaking in a jumbly mass. 
Suddenly $\mathrm{Pa}$, from his precarious perch on the box, let out a yell. After a few seconds, Patsy, our driver, brought our junk heap to a standstill. This had to be effected by coaxing the gear into reverse, so that we rolled a few hundred feet before coming to a full halt. Pa leapt out and ran back along the beach. I must say he was an odd-looking figure - his hip boots bogging down in the loose sand.

We tried to be very casual but we were convinced that $\mathrm{Pa}$ had lost his mind. Finally, he arose from the deep, dragging a heavy object after him. It was a large and very dead porpoise which $\mathrm{Pa}$ had firmly by the tail. He eased back to the beach buggy dragging his booty and looking for all the world like the 40 -fathom codfish advertisement. He asked us to alight and view his prize, which we did. We tried to look appreciative.

Then we were asked to hold the beast in our laps while we continued our way homeward. I kept thinking how remarkable it was that $\mathrm{Pa}$ had seen anything floating in that surf, and, having seen it, cared enough to chase into the water, get wet, and then give his family the doubtful pleasure of carrying it home. It must have been something rare, but it certainly looked ordinary, this critter whose aroma circled around us like a thick fog.

This find, however, turned out to be a specimen of a Prodelphinus, one of the swift racers of the ocean of which we had no specimen in the Museum. We were able to ship it entire, as it was cold weather, and we could have drawings made as well as a complete skcleton prepared after it arrived safely in Cambridge. 


\section{CHAPTER XXII \\ Latin America}

I

HAVE long felt that I owed a debt of gratitude to many friends in Latin America. When my old friend Wilson Popenoe, who is building the Pan-American Agricultural School for Mr. Samuel Zemurray and the United Fruit Company near Tegucigalpa, said, "You should write up your experiences in Central and South America," I made up my mind to do jast that. Experiences of travel in South America, however, have inspired books of all sorts - old books mostly good, and modern books, a few good, more indifferent, and many not worth the paper they are written on.

I am going to write mostly of friendship, not scenery. Suppose you had been with me when our steamer anchored in the lovely harbor of Bahia in Brazil. I was delighted with the scene, as were my family, but was still more pleased when a handsome young man stepped up to me and said, "I am Afranio's brother." Afranio do Amaral was first my student and then one of my warmest friends. I did not then know that his brother was President of the State of Bahia. He was the soul of courtesy and hospitality. We saw everything from the superb tiles in the Church of São Francisco to the market where you can purchase anything from a marmoset to a mango. To my dying day I shall remember a red snapper cooked with a hot tomato sauce as one of the most delicious dishes I have ever tasted. 
Eventually we arived in Rio, where Afranio met us with Lucia, his lovely young wife, and his children. It was a joy to be together again, after several years. Rosamond and the girls stayed in Rio, but Afranio and I went on to São Paulo. He was then Director of the Serum Therapeutic Institute at Butantan, the "Snake Farm" to tourists, and of course we had a thousand things to talk over together; my old correspondent Oliverio Pinto of the Museu Paulista to see; and Lucia's family to salute, the Assumpcãos, whose lovely home it was a privilege indeed to visit.

Years before when we were first in Rio I met Dr. Orville A. Derby, then head of the Geological Survey of Brazil. It was in his office that I first realized that there were vertebrate fossils to be found in Brazil. This fact lay in the back of my mind for years until I had the good fortune to play a small part in persuading Professor Alfred Romer to come to Cambridge from the University of Chicago. We soon began to plot a Brazilian expedition to hunt fossils. He had exactly the right man to lead it: Llewellyn Price, an artist to his finger tips, a splendid field man with a great nose for a fossil, and, above all, born and raised in Brazil. We teamed him up with Dr. T. E. White, later to be my companion in crime in the fossil fields of Florida, and down they went to get a magnificent collection of Rhynchosaurs, Cynodonts, and Dicynodonts, all primitive reptiles, many, many millions of years old. They have bones as heavy as a small rhinoceros: the remains of one of them would come to several hundred pounds.

One of the best of these skeletons, prepared for mounting, we sent back to Brazil as a good-will offering, and 
with it went Price, who now has been in Brazil for several years, the very best sort of good-will envoy.

Harvard and Brazil have long been allies. On the wall of my office hangs a picture inscribed, "To Mrs. Agassiz from Dom Pedro d'Alcantara, Boston, June 14, 1876," a souvenir of the Emperor of Brazil's visit to Mrs. Agassiz after the Professor's death and after the Emperor had more or less voluntarily laid down the Royal Crown.

The Botanical Garden of Rio is comparable only to that of Buitenzorg in Java. In some respects, however, it is more spectacular and more instructive, for it is divided into sections, one growing the xerophytic vegetation of the deserts of Ceará, another filled with the incredible forest trees of Amazonia, a third with orchids, a fourth with enormous palms, and so on. Dr. Campos Porto was Director when last I was there, and his first words were to ask about the health of my beloved colleague Oakes Ames. They had botanized together years before orchid hunting, for the Ames herbarium of orchids is probably the richest and best organized in existence.

We have pleasant recollections of Montevideo. When first we were in Buenos Aires, Florentino Ameghino was alive. And it was of him that Dr. W. B. Scott wrote: -

$\mathrm{He}$ and his wife lived like hermits in a corner of his large house, all the rest of which was given up to his shop and his collections. Every penny which he could scrape up was devoted to the publication of his papers and to keeping his brother Carlos at work collecting fossils in Patagonia. In the history of science I do not know a finer example of courage and devotion under 
the most adverse circumstance. The long brave struggle was, at length, fitly rewarded by Ameghino's appointment to the Directorship of the National Museum at Buenos Aires, a post which he held to the end of his life.

Santiago de Chile was and is a superb city, the snowcapped Andes in plain view and the lovely little park, called the Cerro Santa Lucia, to stroll in during the late afternoon. I wonder whether the old sign over the entrance to the Protestant Cemetery there is still in place. The inscription ran something like this, "Here lie interred those who, unable to enter Heaven, were not welcome in Hell." If the Good Neighbor Policy works both ways, and I believe it does, this sign has probably long since disappeared.

General Kilpatrick, an old friend of my father, had married a Chilean lady, a Valdivieso. The widow was still alive when we were in Santiago for the Scientific Congress in 1908 . She was a direct descendant of Ponce de León, knew everybody in Santiago, and, though we were entertained officially as delegates, she showed us many charming attentions which opened up the life of a most polite and cultivated society.

It is worth a trip to Peru if only to hear the Peruvians speak Spanish. They, with the people of Colombia and of Costa Rica, do perfect justice to the stately measures of that most majestic and sonorous of all the languages. I say this praying that my Brazilian friends will not be furious at the implied slur on Portuguese. Whenever I read a bit 
of Camoëns I am inclined to think that I have been unjust to the language of Brazil.

My daughter Mary and her husband, Alfred Kidder II, have traveled far and wide digging for prehistoric pottery, first in Venezuela where I was able to pass them on to old friends, then in Honduras where the farmers and officials of the United Fruit Company showed them many courtesies while they worked in the prehistoric cemeteries near Lake Yohoa and the Ulua River. Latterly they have concentrated on Peru where Dr. Julio C. Telio, once here at Harvard and an old friend of mine, and his colleagues have made every day of their two long visits golden days indeed, as witness my daughter's published diary, No Limits but the Sky, which has been praised by others than her affectionate father.

I have been asked time and time again what railroad ride I have enjoyed above all others. This question is a good deal like "Which is the most beautiful harbor in the world?" - something which has been widely discussed since the beginning of time. But for my part I don't think there is any scenery so lovely as that which meets the eye when the train turns sharply inland after leaving Siquirres in Costa Rica and begins to climb up to the central highlands on a road that clings precariously to a little shelf beside the roaring Reventazon River. The forest along the lower Motagua in Guatemala is perhaps equally fine and varied, but in Costa Rica the river pitches down much more steeply. As you mount upward there are frequently longdistance scenes down the valley toward the sea which are ineffably lovely. 
Costa Rica is one of the most charming of all lands. In addition to breath-taking scenery in all directions, it has a delightful, cultivated, intellectual society in its capital. I may add also that many of the ladies are singularly lovely.

With horses and guides kindly lent us by my friend Charles Lankester, who plants coffee at Las Concavas, Ned Hammond and I once made a trip to the summit of the volcano of Irazt and spent a couple of nights camped just below the cinder cone. It was possible to walk to the top of the mountain, with the cinders crackling with frost underfoot, and as daylight came to stand and watch the sunrise. The clouds were far below us. At last we could see the blue sea of the Atlantic far away and over 10,000 feet below. Far and wide in every direction the mountain tops stuck up like islands in the deep white sea of fog. In a few hours the fog all burned away to reveal the incredible beauty of the valleys of this crumpled-up land. Nothing in the mountain forest is more breath-taking than the orchids, which are simply beyond description. Imagine a mass of corsage Cattleyas ensconced on a branch directly below you as you peer down some little mountain canyon. perhaps a hundred blossoms, a flaming mass of scarlet, which would fill a bushel basket.

I remember every hour of my considerable number of visits to Costa Rica with lasting pleasure. The mainland of Central America has conspired to treat me very kindly, something which the waters off its coast have usually quite reversed. I never in my life have suffered more acutely than in going from port to port on those two little submarine chasers, the Wild Duck and the Victor, of doleful memory. I appreciate the kindness of the United Fruit 
Company in allowing me to use them, but of all the motions producing seasickness, from which I have suffered acutely all my life, nothing was ever contrived in the shape of a boat which could touch these two craft for unspeakable gyrations.

Guatemala to me means the Popenoes. They live in the house about which Louis Adamic wrote the book called The House in Antigua. Do read it. You will then know exactly what I mean. And to me Guatemala also means the colorful Indian cities and towns, with their individual and characteristic costumes; the sumptuous ruins of Quirigua in their setting of one of the finest bits of high rain forest anywhere to be found; and delightful, lazy week ends spent at the hospital at Quirigua with Dr. Macphail, whose cook made what always seemed to me the best tortillas in all Central America. What Dr. Macphail has done in alleviating human suffering in a land where skilled medical care is not widely distributed could only be handled justly in a book devoted to the men in charge of the far-flung hospitals of the United Fruit Company.

It is curious how a single person or a single object recalls a whole concatenation of scenes and personalities. Mention dancing-girl orchids and the market at Salvador flashes to mind. You can buy these gemlike flowers, in armfuls of long sprays, for a few cents and then your mind jumps to Madam Dueñas and her wonderful collection of pottery to whom and to which Warren and Irene Robbins introduced us. Warren was our Minister to Salvador when the Utowana stopped to bring mangosteen 
trees from the Canal Zone to Don Felix Chaussay, then Minister of Agriculture, who was extremely anxious to introduce this fruit into his country. I hope they throve and are bearing now.

While the colorful Indians have about disappeared in Salvador they still remain in Guatemala, each Indian city having its different and attractive costume. The extraordinarily interesting religious observances are perplexing and difficult indeed to study unless you speak one of the Mayan languages, as I, unfortunately, do not. I have seen sand paintings as elaborate as anything which the Navajos ever made, on the floor of the Church at San Antonio de Aguas Calientes.

Why North Americans have been so slow in learning the charms of Latin America is difficult to explain. I suppose it is because of the language barrier. North Americans are generally a unilingual people. Cultivated South Americans are bilingual but their second language has been French. Most North American college executives a few decades ago rather dreaded the advent of Latin-American students. They usually had too much money and too few morals. The truth was the best of them went to study in France. Now this is all changed and since I have served on the Latin-American Board of the John Simon Guggenheim Memorial Foundation I have had to do with the bringing to America of a number of most outstanding young scholars. It has been sad, at times, to see the way these young men, after they have completed their studies, have been grabbed up and given positions in American institutions, when the purposes of the Foundation would have been 
better served had they returned to replenish the faculties of their native lands.

Americans at last are beginning to learn of the joy of traveling in Mexico. The new highway has played some part, but the interchange of students, North Americans who have attended the summer school at the University of Mexico, and the reverse process, have played a part which it is quite impossible to exaggerate in building up the friendliness which now exists and which should have existed for many years.

I remember in particular a trip we took to Mexico in April I93I, while our ship, the Utowana, lay at anchor in Mazatlan Bay. My wife, my daughter Mary, and I got a horse and wagon and set out after fresh fruits and vegetables.

We were some dozen miles inland when Rosamond spotted a tree laden with limes. There was a small dusty roadside general store near by and I asked the storekeeper if he owned the lime tree. He said yes. I asked if he would sell us some limes. He said no. I was surprised, as he didn't look very prosperous and I thought he would seize the opportunity to do a little business. Not so. While we talked and talked, as one does in Mexico, I learned that the lime tree was very prickly, that picking limes was tiresome and dreary, and if he picked them he feared he would have to charge more for them than we were likely to pay, and so on. Finally we agreed to pick them ourselves and then set a price after we had seen how many we secured.

Down the road came a small bunch of scrubby cattle, 
little more than calves, and behind them trudged a barefoot Indian boy, his white cotton shirt hanging out over his white cotton pants, and an enormous sombrero on his head. Every once in a while he flicked at something with his long-lashed whip and then stooped and picked the something up and put it in his pocket. It was not until he got quite near us that I saw what he was doing. He was killing lizards with a skillfully directed snap of his whiplash. This, of course, was an answer to prayer. I asked him why he wanted them and he said to feed his mother's cats. I offered him a dime and looked over his gamebag. Some of the lizards were badly smashed. Others were not. I picked out the best and thanked him. One of them turned out to be a new species which I named after our good ship, Anolis utowanae. I had already named for her owner a beautiful new form of the same genus from Ruatan Island in Honduras.

Cuba has been almost a second home to me and I feel free to visit my Cuban friends' houses and discuss with them their most intimate problems in the frankest way. Dear Don Carlos de la Torre is an old friend indeed and to his younger satellite I almost feel in loco parentis. This very morning I received a letter from one dear boy, who writes me: -

I do not remember if I ever told you that I was engaged. I feel badly not to have let you know. We are going to be married in December. I would have liked very much to wait until your next trip south in order to have you stand as testigo but because of the war I doubt if it could be arranged. The girl is a very 
nice one and I have talked so much to her about you that she feels she knows you as well as myself.

A professor in Brazil writes me: -

I was awfully pleased to receive your letter of June I 7 th and want to thank you very much for your kind attention in giving me the information I liked to have on the Loew Collection. By reading your letter I see now that I had not failed in my judgment, when I understood that I had conquered a good friend, after your always remembered visit to the Oswald Cruz Institute.

And but a month ago Dr. Afranio do Amaral writes: DeAr Tom:

I was delighted beyond expression to find on my desk the other day Mary B.'s book, entitled No Limits but the Sky and telling about her and Teddy's travels in the Andes. Please thank her for this splendid surprise and most appreciated souvenir.

How would you like to write Portuguese with that style?

I could go on forever extolling the charms of friends from Cuba and Haiti, from San Domingo to Patagonia. They have meant a great deal to me. I have entered into their joys and sorrows and they into mine, and I salute them, one and all.

My old friend Dr. Herbert Clark, formerly on the Medical Staff of the United Fruit Company, now the 
Director of the Gorgas Memorial Laboratory in Panama, has for years been interested in a snake census, to find out the relative abundance and the distribution of the species dangerous to man. He had collected thousands of heads, which have been identified, and the information has been useful in determining the procedure connected with the preparation of antivenin.

The procedure is to immunize horses from which the anti-venomous serum is to be prepared with poison taken from the most abundant dangerous species in any given locality. Following the methods used in Brazil, the snakes are captured and kept in a pen and milked regularly of their venom, which quickly dries into crystal form. This, diluted, is then injected, first in infinitesimally small doses, into strong, healthy horses. The dosage is gradually increased until the horse receives without injury amounts of venom which would normally be fatal to perhaps a hundred horses. Their tolerance builds up rapidly.

The United Fruit Company, operating in those parts of Central America where poisonous snakes are abundant, had always been apprehensive that some of their best field men might be bitten and lost. There were other demands for serum in the Canal Zone, in the Army, and elsewhere. When Dr. Afranio do Amaral had finished the work for his Doctor's degree here he generously consented to help organize an Antivenin Institute, and we set up a field station at the Experiment Station belonging to the United Fruit at Lancetilla, Honduras. A commercial organization in Pennsylvania arranged to produce the antivenin if we could supply the venom.

Wilson Popenoe and Dorothy, his wife, were enthusi- 
astic supporters of our idea. From high to low, not only Pop, as my daughters call him, but everyone else connected with the Fruit Company has always been cordially helpful in developing any scientific project which came to their attention, and I felt pleased and proud to be able to repay some of the favors which I have received at their hands. I knew that the Snake Farm would be a tourist attraction. Many ships were entering or leaving the port of Tela, which at that time was producing vast quantities of fruit, but there were no attractions at that port to amuse tourists while the ships were being loaded.

The snake pen, built of galvanized iron for a nonclimbable wall and shaded by an enormous manaca palmthatched roof, was of unfailing interest, particularly as we had arranged to have Douglas Marsh or Raymond Stadelman milk the snakes on days when tourist ships were in port. The natives proved efficient collectors when they once knew what it was all about, and a number of them owe their lives to serum made with the help of the snakes they caught. The fer-de-lance was very common about Tela. The snake is bold and quick to strike and, though active only by night, has a way of hiding by day under the banana trash, dead leaves, and old stalks, which naturally abound in any plantation. The barefooted natives ran a considerable risk.

We gathered enough venom to last for many years and then abandoned the Snake Farm. Now, however, with the increase of military activity in the Canal Zone, the demand for antivenin has suddenly stepped up and I should not be at all surprised if we had to start collecting snakes again. 
It was by rather good fortune that when he wanted a medical entomologist for the staff of the Gorgas Memorial Institute, Alexander Graham Bell Fairchild, David's son, was prepared and ready for me to recommend for the position. I felt sure of this choice, for not only had I known him for many years, but he passed a most excellent doctor's examination which I had attended a short time before. And fortunately Dr. Marston Bates, whose brilliant examination I had attended a number of years earlier, joined the staff of the Rockefeller Foundation and has distinguished himself in research concerning the transmission of malaria, first in Albania, then Egypt, and now at Villavicencio in Colombia. Marston married David's talented daughter Nancy Bell, who was able to adapt herself to life in foreign parts as well as my daughter Mary has. All in all, the principal gain which I myself derived from the excuse to visit Honduras on various occasions was the growing intimacy with the Popenoes, whom we have warmly adopted as members of our family. Dorothy Popenoe died in Tela and is buried in the lovely garden at Lancetilla. After a long interval Pop, as is usual with him, proceeded to do the impossible and found another lovely wife as charming and talented as was Dorothy. Helen is now helping him build the Pan-American Agricultural School at Zamorano, not far from Tegucigalpa, the capital of Honduras. 


\section{CHAPTER XXIII}

\section{Africa}

For years press of work in Cambridge had forced me to concentrate on short journeys to the West Indies and Central America; but deep in the background of the consciousness of every real "bug hunter" is an overwhelming desire to visit Africa, so that finally we ended up and by we I mean my wife, Julia, Louisa, and Margaret Porter - in making a quick round trip to get the high lights, and especially to visit the Kruger Park. This proved so enjoyable that we went again the following year, especially to see National Parks, as I have recounted hereafter.

If - in the peace to come-you sail up the east coast of Africa, take a freight steamer that stops at many places and does not hurry in and out of the ports too quickly. Thus on a freighter we left Lourenço Marques and put in at Beira, which presents little of interest but the fish market. There we picked up quite a good collection of fishes. There was little else to do. Fish markets vary enormously. In some you find that the habits of the people are such that only a few special species are brought in; in others, where the population is omnivorous, fish may be found in bewildering variety. This was the case in Beira, and while we had no idea of making a collection, when Rosamond and I began to walk around the market we found such an extraordinary variety of curious and in- 
teresting fishes, and above all small species or young specimens, that we were able to get really a very fair variety. Luckily, there was a good drugstore in town which had formalin for preserving and some wide-mouthed jars, and the result of our fortunate visit to this market was a concise little paper by our friend Henry Fowler of the Philadelphia Academy, who was glad to make the identifications and publish them, since he said records were few for this section of the African coast.

Then came Mozambique, hoary with age, and like an old, rather down-at-the-heel town of Latin Europe; next Porto Amelia with its lovely bay and Dar es Salaam, modern, obviously built by Germans, neat and well laid out.

Zanzibar, however, is the spot of spots, a fascinating old labyrinth of unspoiled Arab architecture. No one can ever forget those stunning carved doorways in what we would call adobe buildings, nor do many who tread its little narrow streets realize that those which have not been laid with asphalt in recent years are paved with cobblestones which came in the ballast of ships from Salem. The stones, on reaching the port, were tossed out and the cargoes of ivory and cloves came on board and the thrifty Arabs made good use of them.

Here I played a trick on the family. As we were walking along I spotted some durian fruits hanging in a stall in the market and I bought one, said nothing about it, and when we went to lunch on the roof of the funny little hotel - an old Arab house remodeled with its high, adobe parapets and much needed shade in the form of an awning overhead, for the dining room floor is also the roof I prepared a surprise. I had one of the native boys take 
the durian and pick it apart, as one does preparatory to eating it. I then put this in a covered dish and set it in the middle of the table. In due season the family arrived and seated themselves prepared to complain about the victuals. We had soup, fish, and an excellent curry which, of course, some of my family don't like. However, long before the curry stage had been reached there were angry sniffings and remarks such as, "My, there's obviously a clogged drain in this hotel," or "I think it is a dead horse in the next yard which should have been buried days ago." This continued until time for the dessert, when I lifted the lid and instantly the table was vacated. One brave member of my party tasted a sample and disappeared at once so that I could continue to clean up the remains of the durian at leisure, for I am just perverted enough to like this curious mixture of peach, garlic, and almonds.

I still wear the pongee-silk suits which I had made to order in Zanzibar at one South African pound each. I never pass the case in the Peabody Museum in Salem where the old uniforms are exhibited without marveling that one could wear such clothing in the tropics and survive. Imagine being consul in Zanzibar in thick broadcloth covered with gold lace. However, thin clothes for summer are recent. Our grandfathers wore broadcloth all the year round, and less than a hundred years ago British troops were shipped to India with the same uniforms they wore in England.

At Tanga we motored up to the Botanical Garden at Amani in the Usambara Mountains where we had friends on the staff of the institution. We stopped along the way to watch a column of army ants as they crossed the road 


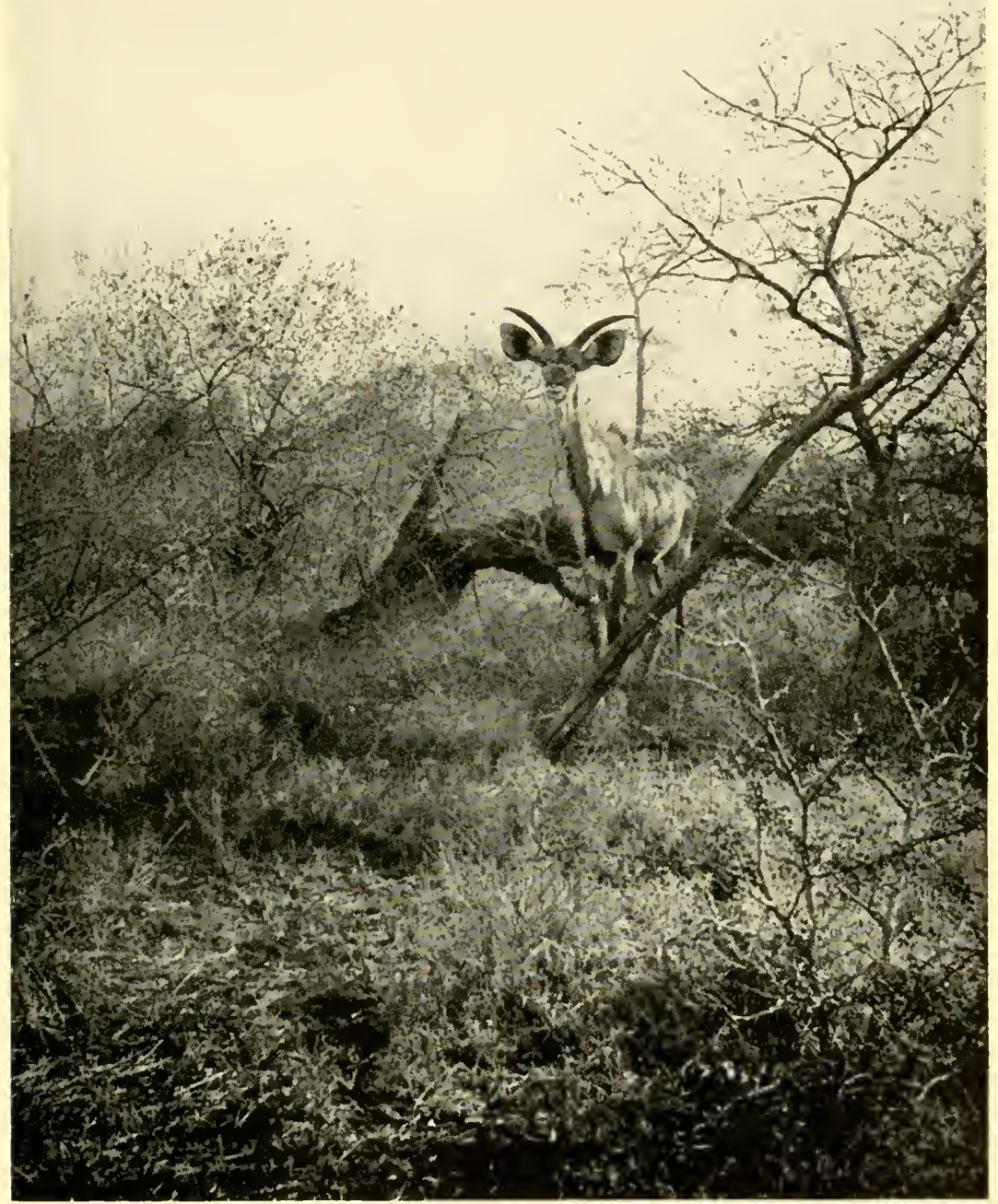

Photo by M. D. Porter

A yearling Greater Kudu in the Kruger Park

August 1935. Taken with a I A FPK universal focus Kodak at a distance of twelve feet 



\section{Africa}

like a strip of blackstrap molasses flowing slowly along, and were overjoyed when several magnificent black and white Colobus monkeys hurtling their way through the high forests jumped across the road from one high tree to another, one passing directly over the top of one of our motorcars. The forest garden at Amani is magnificent and the Germans who laid it out in a better day obviously devoted a great deal of money to its development and to the scientific work which was carried on there. The cinchona plantations were still in evidence, though somewhat overgrown, where the Germans produced enough quinine to take care of their army through the whole long East African campaign.

Once we motored from Tanga to Mombasa, a bad road but through lovely country, and once, also, we were long enough in Mombasa to go up to Nairobi and drive out to look across the Riff Valley. Since that day I have always hoped I might return. Not only is the scenery sublimely beautiful, but the animals present a constantly changing scene. Giraffes, gazelles, gnus, hartebeests, ostriches, are constantly before the eye, and with luck one occasionally gets a glimpse of rhino, hyena, lion, or leopard. Indeed, for hours before you reach Nairobi you pass through a great game reserve with hundreds, and of ten thousands, of animals always in view.

Aden is much more interesting than most people realize, if you have time to drive off the peninsula and see some of the old Arab towns on the mainland, and above all to visit the prehistoric tanks - giant cisterns hewn in the rocks - high in the stony hills behind Steamer Point.

Djibouti is a hell hole, and Port Sudan, in the middle 
of summer, is warm enough to talk about afterwards. We have been there several times and on one occasion had a rather amusing experience. We had driven out to see the camel market and the old Fuzzy-Wuzzy town of Suakin. We returned to Port Sudan panting. I saw a sign that said "Cold Beer." I sat down under a sort of arcade beside the dusty square and while I proceeded to try the beer, my wife went off to purchase something or other. I heard her say to a portly Greek, "My, what good English you speak." He replied, "I ought to; I was born in Lawrence, Massachusetts."

If you're lucky you can see flamingos in the salt pans near Aden and near Port Sudan too, and if your ship does not happen to be one of several coming into Aden on the same day, so that the birds are too well fed, you will enjoy the extraordinary flight of Bramany kites which roost in countless multitudes on the pinnacles of rock about the town and which come swooping and diving in graceful flight to pick up such bits of offal as may be thrown overboard. I was prepared for this scene and had all hands well stocked with ancient griddle cakes, biscuits, and other objects which we tossed into the air for the fun of seeing the kites swoop and catch them before they reached the water.

Egypt in summer, of course, is pretty warm. On the other hand you have it to yourself. The motor ride from Suez to Cairo across the desert, if you take it at night, is far from uncomfortable and the Sphinx and the Pyramids, I think, look their best undecorated by tourists.

One summer we decided to "do the Holy Land." A most comfortable train from Cairo takes you to the Canal, which you cross at El Kantara. On the ferry across the 


\section{Africa}

Canal time passes easily for a most extraordinary conjurer stays on the boat and goes back and forth, entertaining. His principal trick is to take a little chicken, seize it by the wings, give it a sharp snap and, lo and behold, he has two chickens instead of one. He is called the gilly-gilly man.

On one occasion we fetched up across the Canal and were about to get in the sleeping car - in fact all the female members of the outfit had turned in and I was in the passport control office - when the officer suddenly spotted the fact that my daughter Julia, having had a birthday a few days before, had reached an age when she should have a separate passport of her own. This, of course, it was impossible to get and, after a lot of talking, he agreed metaphorically to turn the calendar back a few days, else that trip would have had to be called off.

From El Kantara the train runs to Haifa, but if you go to Jerusalem you get off at Lydda and take a branch line. One passes in sight of the Cave of Macpelah and across the stony draw where David smote Goliath. I think the thing that is most striking about Palestine is its tininess. You can stand on the Mount of Olives and look down and see the Dead Sea on one side and the whole city of Jerusalem spread out on the other. I am not going to discuss visiting the Holy Places. Some of the sites provoke deep emotions, a real stirring of the soul, while others are quite the reverse, and in summer the dark covered tunnels which serve as streets stink awfully. One afternoon we drove down to the Dead Sea Valley. The children and Peggy Porter went in bathing. We sat and mopped our brows for, in spite of being in a region where drought is unbroken, 
the Dead Sea Valley is damp with the evaporation of the surface of the great lake. The Jordan River pours into the upper end of the Dead Sea but there is no outlet except by evaporation. The temperature in the valley, surrounded by broken hills and 500 feet below the level of the sea, in August is grotesque.

Jacob's Well is very impressive. How this rock-cut tube but a couple of feet in diameter and enormously deep was ever hollowed out by primitive man is hard to understand, but made it was and down it reaches to water which is cold and crystal clear. It is near Nablus, where the poor, tuberculosis-ridden remnant of the Samaritans still walk the streets.

Nazareth is lovely, the Sea of Galilee a gem, and the site of Capernaum perhaps the most charming of all.

Before we motored down to Haifa to embark we went out to the Cave of El Athlit at the Wadi El Mughara. The British Museum has been digging here for some years in an extensive cave. A number of Neanderthaloid skeletons have been recovered, and picking around the sides of the excavation I fished out a jaw of a red deer and the bony scute which once underlaid the scale of a crocodile. This simply served to bring to mind the fact that the British Museum had found remains of hippopotamus and a wide variety of other African animals in this region which now is too completely bare to support much of any wild life mice and a few foxes at best. I wonder if the fact that man took the goat into domestication in this general area is not the reason for all this barrenness. Goats and goatherds still roam the landscape as they have undoubtedly been doing for several thousand years, and the fact that goats can gnaw 
the bark off trees as well as destroy herbaceous vegetation is, I believe, the probable reason why so large a portion of the shores of the Mediterranean basin are now desert.

John Phillips met Major Hobley in London and thus became interested in the Society for the Preservation of the Fauna of the British Empire, feeling that some similar organization should exist in the United States. He and some of his friends established the American Committee for International Wild Life Preservation. This committee is active to this day, and has gathered together and prepared much interesting information concerning the history and the causes which have caused the extinction of so many forms of animal life. To know more in detail concerning what had been done in South Africa and to encourage the conservationists in that part of the world we made a second trip there in 1936 . We sailed from $\mathrm{New}$ York to Gibraltar, spent about ten days motoring through southern Spain, and then took the ship from Gibraltar to Cape Town via Dakar.

My wife and I are fond of visiting markets. I can close my eyes and see again the brilliantly costumed Negresses of Dakar, the Bugi fishermen at Macassar in the Celebes, the fish market at Beira in Portuguese East Africa, and heaven knows how many others.

Once or twice, however, my conspicuous size has made these visits amusing as well as interesting. I remember an old woman in the market in Cienfuegos, which I have visited hundreds of times, who said, "Look at the walking ceiba." It was no compliment. The ceiba is that enormous and ungainly tree with a leprous-looking bark - certainly 
one of the most clumsily shaped objects in the whole plant kingdom.

On another occasion at Santiago de Compostela in Spain a slatternly old pod said to a friend beside her, "That chunk of humanity ought to have snow on it." My answer surprised her. I took my hat off and said, "Look, it has." Of course she had no idea that I knew Spanish and she used a pretty informal term for "chunk of humanity." It was ese cacho de bombre.

I shall not elaborate this thesis any further, for many of the remarks made about me will not bear repetition in any society, polite or otherwise.

Dakar is a well-built and typical colonial tropical city in the French style. It presents little of interest except the noisy and colorful market where the gaily dressed Negro women look as if they all came from either Martinique or Guadeloupe, but for the naturalist there is a real high light in the neighborhood provided he has the good fortune to find it out. We did. We drove some miles into the country. Our real object was to see what there was in the way of bird life but what we found was a great stand of enormous baobab trees, I really believe the most wonderful grove of its kind in the world. These trees must be extremely old and most of them have been chopped and hollowed out, apparently to conserve the rain water, for while this is a deserty part of Africa I take it that "when it rains it pours." The Arabs say that the baobab tree, by a divine mistake, grows upside down and that the strange, ragged branches which we see extending from its enormous trunk are really the roots sticking up in the air. None of the trees were very tall but certainly few of them were 
less than forty-five or fifty feet in circumference. They swarmed with gray hornbills, purple rollers, brilliantly colored bee eaters, and agama lizards. Although we had seen big baobabs at Mombasa and elsewhere in East Africa, these giants at Dakar certainly stand out in memory.

At Cape Town, after visiting the splendid South African Museum, the lovely botanical garden at Kirstenbosch, the only place where the famous silver trees are still to be seen, and with a superb collection of Proteas and heaths, we went again to the University at Stellenbosch, and then set forth on a long tour. We hired a Dodge truck, a sort of delivery-wagon affair, which carried all our goods and chattels - as well as shovels, for we knew the roads would be bad, some canned goods, and other odds and ends. My daughter Julia rode in this with one of our Boer drivers so that she could help him by taking a turn at the wheel. The rest of us rode in another car, Peg helping with the driving of this one. Leaving Cape Town we started straight south, crossing the lovely Sir Laurie's Pass, for our first destination was the Bontebok Reserve at Bredasdorp. This strikingly beautiful antelope, the bontebok, occurred only in a region which is now all farming country, and thanks to the Albertyn family some of them had been preserved on one of their farms. Finally the government bought a considerable area of the Strandveldt, fenced it, and twenty-three of the antelopes were successfully moved there. By now there are probably two hundred individuals and the herd is thriving. We motored on to Mossel Bay and saw the sea-lion colony on rocks only a few miles from the city. This spectacular herd is capable of development 
into a real attraction for visitors. At present few people realize that it exists at all. Our next stop was Port Elizabeth, where the ladies of the party, being excellent sailors, which I am not, went forty miles offshore to Bird Island, their visit luckily coinciding with one of the semiannual trips of the lighthouse tender. They saw a wonderful show of gannets, but only a few of the penguins which they were especially hopeful of seeing. The lighthouse keeper told Rosamond that within a few days he would look out from his house and instead of seeing the whole island snow-white with gannets they would all be gone, and the penguins would be swarming ashore to take up the same nesting ground.

While the family were at Bird Island Mr. Herbert Lang, who had come from Pretoria to join us, and I went out to the Addu Bush. This park, recently established, shelters the last remnant of the true South African elephant. There are also bush buck, buffalo, and various small antelope, but it was established especially to preserve the few remaining individuals of the heavy-bodied, short-legged cape elephant, characterized by very short and very thick tusks. On account of the tendency to wander, these elephants have given a great deal of trouble, especially to the orange growers, whose groves adjoin their range. $\mathrm{A}$ few years ago Major Pretorius, a famous Boer hunter, was commissioned to kill off all the elephants. He almost succeeded in doing this before the outcry of popular indignation put a stop to the slaughter. The Reserve has now been somewhat enlarged, I am told, and the elephants are kept in control with rockets and flares and by persuading the orange growers to dump all their cull oranges in a certain place where the elephants 


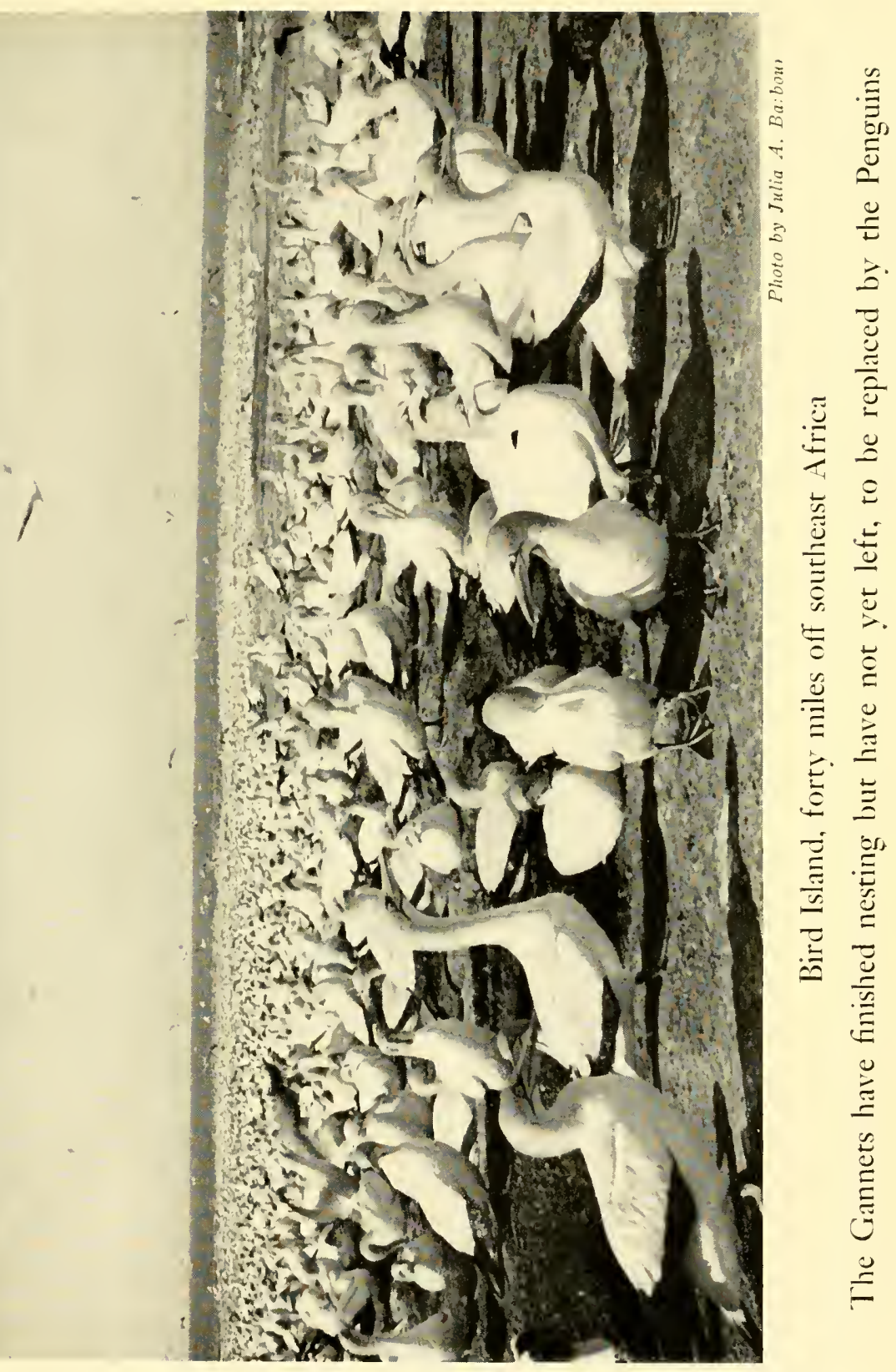



can go and feed upon them. The herd are holding their own now, and slowly increasing in numbers.

After this visit we made a long tour through the Knysna and Tsitsikamer Forests, through the native reservations in the Transkei, and through Big and Little Pongoland. This gave opportunity to visit our friend Mr. Hewitt, whose excellent museum at Grahamstown unfortunately recently has burned to the ground. Hewitt kindly guided us to one of our most interesting experiences during the whole trip. This was a visit to some rock shelters where there were excellent bushmen paintings and carvings on the rocks. Major Shortridge showed us his wonderful mammal collection at the Kaffrarian Museum at King William's Town. He certainly has one of the finest collections if not the very best in the whole world of the small mammals of South Africa. At Durban Mr. Chubb described to us the excellent service which the museum there is rendering to the school system of the city, a complete co-operation which I should be proud to see copied in Boston, and which has only been equaled, if not perhaps cxcelled, by the work done by the museum at St. John, New Brunswick. Aided by grants from the Carnegie British Empire Trust the Durban museum has been used more or less as a laboratory subject. The population of the city is a considerable mixture. There are many British, a very few Boers, an enormous Indian population, and many natives. By bringing children in groups to the museum and by circulating small collections to the schools a really important educational work has been built up, and it is interesting to see Zulus, in more or less conventional costumes, looking with interest at the objects representing the arts 
and crafts of their fathers or, for that matter, of their neighbors but a few miles away whom they probably seldom get to know or see.

North from Durban we passed through Zululand to Swaziland, making a side trip to spend a few days with Captain Potter, who is warden of the Hluhluwe and Umfolozi Reserves where the last black-and-white rhinoceros are well protected and are steadily increasing. The final high light of the journey of course was the opportunity to revisit the great Kruger National Park. So much has been written about this and it has been so often described that I am not going to attempt to do this again. The Park is as large as the State of Massachusetts, and swarms with countless thousands of animals of innumerable different sorts. In a day driving slowly along its narrow winding roads one may see elephants, giraffe, buffalo, as well as antelopes varying from the enormous eland, as big as an ox, to the tiny steenbok, hardly larger than a fox terrier. We spent a day or two in almost all of the camps from Crocodile River in the south to Punda Maria in the north. Colonel Stevenson-Hamilton, the chief ranger, and almost all of the members of his force of wardens treated us with the utmost courtesy, and many went out of their way to make it possible for us to see rare and unusual animals which could only be found by knowing exactly the place which they frequented, or the exact time of day or night when they were to be seen. After passing up and down the whole length of the Park we left the Union of South Africa at Komati Poort and passed over into Portuguese East Africa at Ressano Garcia. 
As I have said, my wife has the most complete control over her emotions of any person whom I have ever known and, by that same token, is not given to sentimental reflections, or even to reminiscence. So I was surprised the other day when she said, "You must remember to write about the time we met the locusts."

This was indeed an extraordinary experience as we were leaving the Transvaal at Komati Poort. We had heard of the troubles that awaited us at the frontier, so I directed our somewhat officious South African drivers to stay in the cars and let me go into the customhouse and do the talking. I had just received notice of my appointment as a delegate of the United States Government to the International Zoological Congress to be held at Lisbon, and I told the customhouse officers that I was going to give them the pleasure of being the first to offer us Portuguese hospitality. My Portuguese is by no means fluent - indeed it is badly mixed with Spanish, which is for me almost a second mother tongue - but my bastard jargon is glib and I can pronounce the Portuguese words correctly and convincingly. My speech worked like a charm. At a signal from the Collector of Customs, the tall, dignified black askari swung wide the barrier over the road and we rolled into another world.

Komati Poort is a sleazy little town of galvanized iron, mostly unpainted. Step over to Ressano Garcia and you step straight into Portugal - stucco houses painted in brilliant colors, shady arcades about the plaza, a café with little round tables on the sidewalk, a bandstand, and wide, clean, well-paved streets with shade trees. Portuguese East Africa was a most complete eye-opener and the drive down to the 
Port of Lourenço Marques bid fair to be enjoyable indeed. There were lots of birds to look at. Picturesque natives in little groups chattered as they walked along the dazzling highway. We had progressed about half an hour and had stopped to gather some of the seed pods from a giant sausage tree for planting in a friend's garden in Florida, when I looked up and said, "Hurry back to the car. There's a terrible storm brewing." Great black clouds were rolling up on the horizon and quite obviously headed in our direction. So thundergustuous and menacing did they appear that we almost felt the chill wind that often precedes a terrifying storm.

There was only one road and we had to make Lourenço Marques for the cars to return to Komati Poort. As we got nearer to the storm, we marveled that there was no lightning and no thunder, and then we discovered that this was no storm at all but a gigantic cloud of locusts, miles long. In India and in Central America we had seen swarms of locusts, but nothing anywhere on this gigantic scale. The ground they passed over - for they were constantly alighting, eating a little, and then flying on - was completely bare of vegetation, the scorched earth in very sooth. Our wheels slipped and skidded on the pavement, which swarmed with them. Natives with great flat baskets gathered them up for food and the storks had a field day. For a mile or so we passed through the strange semidarkness of this clattering, snapping squall of insects before coming out again into the brilliant sunshine. 


\section{CHAPTER XXIV \\ In Retrospect}

T

LEE RECORD of the evolution of a personality, set forth objectively, can be a contribution to human biology. I do not say that I can succeed in being objective, but I am going to try.

I was so shy and timorous up to the day of my marriage that I bid fair to be a complete recluse all my life. The gentle but firm impact of my wife's personality soon began to change this. She gave up dances and parties and a multitude of admirers for some years of travel, which she certainly, to say the least, never yearned for. Gradually she brought me around to a willingness to meet people and even, for some years, to do a considerable amount of entertaining until the devastating blow of our only son Willian's death changed the whole course of our lives.

I should need to be a Milton to sum up Bill's peerless personality. I can still sit down on well-remembered stones or logs up in New Hampshire and feel Bill's presence just as if he were beside me. He liked the woods as I did, loved to shoot and fish, and did both extraordinarily well for one of his years. He was built like a Barbour - tall, broadshouldered, and very powerful. From somewhere he inherited a perfect sweetness of disposition and temper. In this respect he far outshone either of his parents. He was a fine athlete and a good student, and cared nothing for hardship or discomfort. 
We made together one gorgeous trip alone, up through the Kapitachuan Lakes, not far from the southern end of James Bay. He was eighteen at the time. We camped for several weeks with some Indians, who, in no time, were devoted to Bill, and we had splendid fishing. To cap it all, Bill killed a bear, which was young enough to be delicious to eat; and, as the weather was cool, it kept getting better and better till the last tiny morsel was consumed. Bill had a particularly pleasing, soft, quiet, slightly husky voice, and while he was inclined to be somewhat self-contained, nevertheless I have a feeling that he would not unlikely have become a clergyman. He always followed the lesson at Groton, where he sang in the choir, with his Greek Testament.

Bill and Mary B. were in some respects extraordinarily alike, although she was, and still is, a little golden-haired sprig of a girl, in sharp contrast to her brother. We talked about him the other day as I drove with her to Washington, where she went to join her husband, who is on duty there with the Army. It was a long and rather dreary drive, but made tolerable by the fact that we seldom nowadays have long, unbroken opportunities to chin and chatter together freely. Mary B. also is one of the very few I know who can put up contentedly with discomfort, as I think is well indicated in her book.

I have friends who have suffered the same sort of sorrow which I went through following Bill's death when he was a senior at Groton. The initial stages seem completely unbearable, but gradually, with passing time, scar tissue forms over the open wound; the memories grow sweeter and more precious with the years, and finally almost com- 
pletely substitute themselves for the enjoyment once derived from a human companionship. This has been a consolation to me, and I know it has been for others.

I once thought seriously of shifting over from being a naturalist to becoming a student of archaeology and ethnology, but here my predecessor at the Agassiz Museum, Samuel Henshaw, did me a real favor. He berated me so vigorously and with such vituperation for having any such notion that he really drove it completely out of my head. He cited the enormity of J. W. Fewkes's sins in having made just such a transfer. But I have sneaked off on many occasions to sit musing and wishing that I knew more about the inwardness of archaeology, and, in my off hours, I have read a great deal in it.

I love to go alone to the ruins of Quirigua in Guatemala in that sumptuous forest setting and watch a toucan come volplaning across the ancient plaza. Those gorgeous stelae stand now in solitary grandeur where once the whole scene must have been thronged with brilliantly costumed Indians.

I have listened with breathless enjoyment to the tales Mary B. has told when she and her husband, Alfred Kidder II, have returned from Barquisimeto in Venezuela where they have dug in early ruined sites, or from Lake Yohoa or the Ulua River Valley in Honduras where they found not only buildings of the early Mayan Empire but burials and superb polychrome pottery as well. I followed with feelings of mingled envy and wrath their visits to the highlands of Peru and Bolivia where they worked for many months; envy at the success of their archaeological labors 
and wrath at the stories of the animal life which they saw but which they had not the means or the time to collect for the Museum.

It is always a question whether archacological monuments are more spectacular on their native heath or when delivered into captivity. I believe it is a blessing that that high spidery trestle bridge on which the railroad has to cross to Guatemala City was not sufficiently strong to allow the Quirigua monuments to be transferred to the Capitol. They are superb in their original setting. Now they are safe in situ for all time, thanks to Dr. Alfred Kidder of the Carnegie Institution, and the co-operation of the United Fruit Company which owns the land on which they stand. Some day I hope the remains of the buildings can be pointed up and saved from further disintegration as has been done at Copán in Honduras, where I have never been, or at Xochicalco in Mexico, where I saw the wonderful Teocalli with its frieze of plumed serpents in I9ro.

I was never fitted to be a teacher, but Mr. Lowell gently and firmly led me to a point where I gave a series of Lowell Lectures. These appeared in book form. The book went through two editions and sold much better in England than it did in America. For a while I was much sought for as a speaker describing our travels, but that was in a day when people traveled less widely and less easily than they do now. I even reached a point where I made a speech on Prize Day at Groton School, another at the dedication of the new Museum of the University of Michigan, and a third in the new Biological Laboratories at the University of Richmond. But as I read them over again now these 
speeches do not appear to have been inordinately creditable productions.

I look back on my connection with the development of the laboratories in the Canal Zone, with the Soledad Garden in Cuba, and with the Farm for extracting snake venoms at Tela in Honduras with great satisfaction, for I think all of these organizations have served a really useful purpose in the world. Moreover, in the Canal Zone I chanced to meet the late Charles Cotesworth Pinckney, who became a dear friend. Through him I had the opportunity to love and admire the nearest thing to a saint that $I$ have ever known in human form, his brother-in-law, James Craik Morris, then Bishop of the Canal Zone and Parts Adjacent, later of Louisiana. Bishop Morris and his lovely wife have played an intimate part in my life, and indeed in that of all the members of my family.

For years I was a hypochondriac for a very peculiar reason. I had so definitely in mind what I wanted to accomplish during my life that I constantly suffered portentous symptoms which I expected to lead to death, just as for months after Bill's death I awaited what I was sure was impending insanity. It was not that I was particularly afraid of death, as such, but that I dreaded leaving work that I had planned to do - a mess for others to clean up.

Now all this is changed. When but a short time ago I received the notice of election as Foreign Honorary Member of the Linnaean Society of London - I had been similarly honored by the Zoological Societies of London and Amsterdam years before - I was elated. Years ago I too had set my cap for a little group of hopes: membership in 
the Massachusetts Historical Society and the American Antiquarian Society, the Philosophical Society in Philadelphia, the American Academy of Arts and Sciences and the National Academy of Sciences in Washington, and, to cap all, a Harvard honorary degree. All these have been vouchsafed unto me and many other honors besides, not the least an honorary doctorate from Dartmouth and one from Havana described elsewhere. I have many warm friends in Hanover. I am not going to write a catalogue of the honors, or mention those which came from Europe. They all serve a very great purpose for they mean that you can't quit trying to do your best without letting down a lot of people. Moreover, they keep one humble-minded, which is good for the soul. I wound up feeling that the race was run and I might rest on my oars.

One trembles to think of the heinous nature of the original sin which gave rise to the widespread penance known as an annual report. Along with thousands of other categories of sinners, the preparation of an annual report is a periodical duty for museum directors. I have tried from time to time to make mine a little bit more than the literary dust which is almost inevitable. Sometimes I have succeeded to a surprising extent, so that my friends have occasionally written and said that they read the report of such and such a year with somewhat less loathing than usual. For the writing of the annual report is by no means all of the horror involved; a considerable number of people have to read it, if, perchance, only because they have to make a digest of it to include in their own annual tragedy.

This year, in the midst of a war-torn world, I have been 
thinking hard about the whole question which every elderly person in an administrative capacity has been pondering - as to whether or not he is pulling his weight in the boat at times like this. Or should I shut the Museum up and walk away from it for the duration? Then I read something which clarified my thoughts and proved extraordinarily comforting. You remember when Justice Holmes told of walking down Pennsylvania Avenue on a drizzly night, after a long session of the Court which had involved argumentation, perplexity, and perhaps some bickering, and how raising his eyes and looking ahead he saw out over the Treasury Department clear sky and the shining of stars. Well, the stars have shone for me in the form of some lines recently written by my friend Dr. Albert Eide Parr, the distinguished new Director of the American Museum of Natural History in New York. Feeling that we need a credo for our work, he writes: -

This war is not a war for material gain, but a war for the protection of a civilization. Therefore, the spiritual home front has an importance in this struggle which it never had in the imperialistic battles of old. And on this spiritual home front the war itself imposes a terrible handicap upon our efforts. Democracy is a type of government designed for peace and civilized living. We who have had opportunity to mature in a democracy at peace have learned to love it for the beauty it reveals under the proper conditions for its existence. Our love for it is permanent. We can suspend its freedom for its own protection, and hide many of its beautics to the world, safe in the knowl- 
edge that we shall only long for the day when we can set it free again. But in the meantime, young people are growing up - young people who will spend their formative years in a democracy looking its worst under conditions for which it was not designed. The educational system of which we are a part therefore has the stupendous responsibility to the future of democracy and of our nation, of teaching the generations of tomorrow to love a way of life which by their own actual experience they will only have opportunity to observe as a tired and harassed image of its former beauty in times of peace, and of the beauty it shall regain anew after victory if we do not permit it to become permanently marred by neglect in the meantime.

Of course our efforts would be wasted if victory should not be won. And I know there are people who sincerely believe that for that reason we ought to reduce our cultural efforts to the lowest possible maintenance level. In my opinion the terrible handicaps under which we are striving to implant in future generations an appreciation of the things for which we are fighting today call for the entirely opposite attitude. The effort of our physical victory may also prove wasted if in the meantime we have lost on the spiritual front. And I do not propose to apologize for having sufficient faith in our ultimate victory to consider the continued growth and development of the cultural and educational institutions to be one of the most essential duties which can be borne in our nation today, second only to the duty 
of those defending our right to have the civilization we want. At least that is the conviction in which I my self carry on.

And who but Robert E. Lee could ever have written these words: -

The march of Providence is so slow, and our desires so impatient, the work of progress is so immense, and our means of aiding it so feeble, the life of humanity is so long, and that of the individual so brief, that we often see only the ebb of the advancing wave, and are thus discouraged. It is history that teaches us to hope.

I was greatly impressed as an undergraduate with a remark I once heard Dean Shaler make. Someone asked him why he bothered to go to chapel as regularly as he did. The Dean replied, "I need a spiritual bath much more often than I need one in the tub." This remark gave me great comfort, inasmuch as long years ago I came to the conclusion that an enormous amount of time was wasted washing ourselves when there was absolutely no occasion or need to do so. As for the chapel, I must confess that my attendance there was not very regular.

With later years, however, I have discovered that when I am low in mind I derive great refreshment of spirit and a real lift from good ecclesiastical music. I prefer the Gregorian music and the plainsong of the Roman Church. I started out as a Presbyterian, however, because my father was one, but long years ago I lost interest in the Presbyterian form of worship and went to the Episcopal 
Church, which my wife attended, and was finally confirmed therein. I have served on the vestry of Trinity Church in Boston, and am still Treasurer of St. John's Church at Beverly Farms.

The intricate details of what I believe or do not believe are seldom exactly alike for two days running, but I comfort myself constantly by recalling that I once heard Dean Washburn say in the pulpit of Trinity Church that the greatest words in the Book of Common Prayer were those of Saint Augustine where he said, "Whose service is perfect freedom."

The words come in the Collect for Peace: "O God, who art the author of peace and lover of concord in knowledge of whom standeth our eternal life, whose service is perfect freedom." No words of more stately and majestic serenity appear in a book which stylistically is unapproachable. The only English which equals the King James version of the Bible or the Book of Common Prayer is John Livingston Lowes's "Essay on Appreciation" of that same Bible.

As for the hymnal, that is a quite different part of speech. The number of magnificent tunes is vastly greater than the number of hymns with excellent words. Of course, there are exceptions; "Once to Every Man and Nation," by James Russell Lowell, is to me completely overwhelming. The same applies to the hymn, "Oh Lord and Master of us all," but this was written by Whittier. My other favorite, far and away at the top of the list musically, is "Let all mortal flesh keep silence," the hymn which is sung at the communion service on the great feast days like Christmas and Easter. The tune sung to these words is of utterly 
unworldly beauty and, here again, is one of the rare cases when the words are worthy of the music.

As I say, the details of one's personal religion are nobody's business but one's own. However, I think it is only fair to say, perfectly frankly, that I have got great comfort out of mine, and there have been occasions when, unsupported by it, I should have been hard put to keep my reason.

My family have never mixed themselves very much into my pursuits at the Museum. My daughter Julia worked in the Agassiz Museum for a while in the Department of Birds. She and her sister Louisa are talented executives, active in the management of social and charitable agencies. Besides this, Julia has a fine voice and draws beautifully, if she would only believe it and keep practising. Perhaps she will. My oldest daughter, Mary, happily married to Alfred Kidder II, shares his archaeological interest in South America. His calling brings him to deal with objects frequently of rare beauty, and before her marriage Mary B. worked in the Peabody Museum for some years as an expert pottery restorer. She is also a diarist of no mean talent. When my old friend Ellery Sedgwick reviewed her last book for the Atlantic Monthly with spontaneous and generous praise I was, I think, even more happy than she.

A catalogue of the friendships of any man is bound to be a bore, like Homer's Catalogue of the Ships, but I cannot refrain from mentioning a few of those whose names may not have appeared in the pages which I have written. I think first of Leonhard Stejneger, dux, lex, lux, who began answering my tiresome questions when I was eighteen and 
who is doing so to this day. ${ }^{1} \mathrm{He}$, I think, take it by and large, is the most erudite person I have ever known. Latterly my connection with the Fairchild Tropical Garden in Florida has been a joy. It not only gave me the opportunity to visit David and Marian Fairchild for long periods of time, to install the Palm Products Museum at the Garden, but to add Bob and Nell Montgomery to the list of well beloved. Their superb collection of palms and other plants in southern Florida I have been proud to add to in a little way from time to time; a trifling recompense for the hospitality they have offered me.

To this record I want to add the importance to me and to the Museum of the wise council and generous assistance of my colleagues George Agassiz and George Shattuck, members of the Museum's Governing Board. And let me add this observation here right now and say that it is difficult for me to describe the sensations almost of triumph which I have felt when each one of George Nelson's superbly mounted fossils has been added to what formerly was one of the most insignificant collections in the Museum.

Two keys I have had which have opened the doors to more happiness than most of those on my bulky key ring. One opened the doors of 800 i6th Street in Washington, where Mrs. Hay and later Jim and Alice Wadsworth made many trips to the Capital, which would have otherwise been dreary chores, pure delights, the memories of which still remain fresh and clear. The same may be said of the key to 1720 I Street, where my wife's cousins, Wendell and

${ }^{1} \mathrm{He}$ died after these lines were written February 28, 1943. 


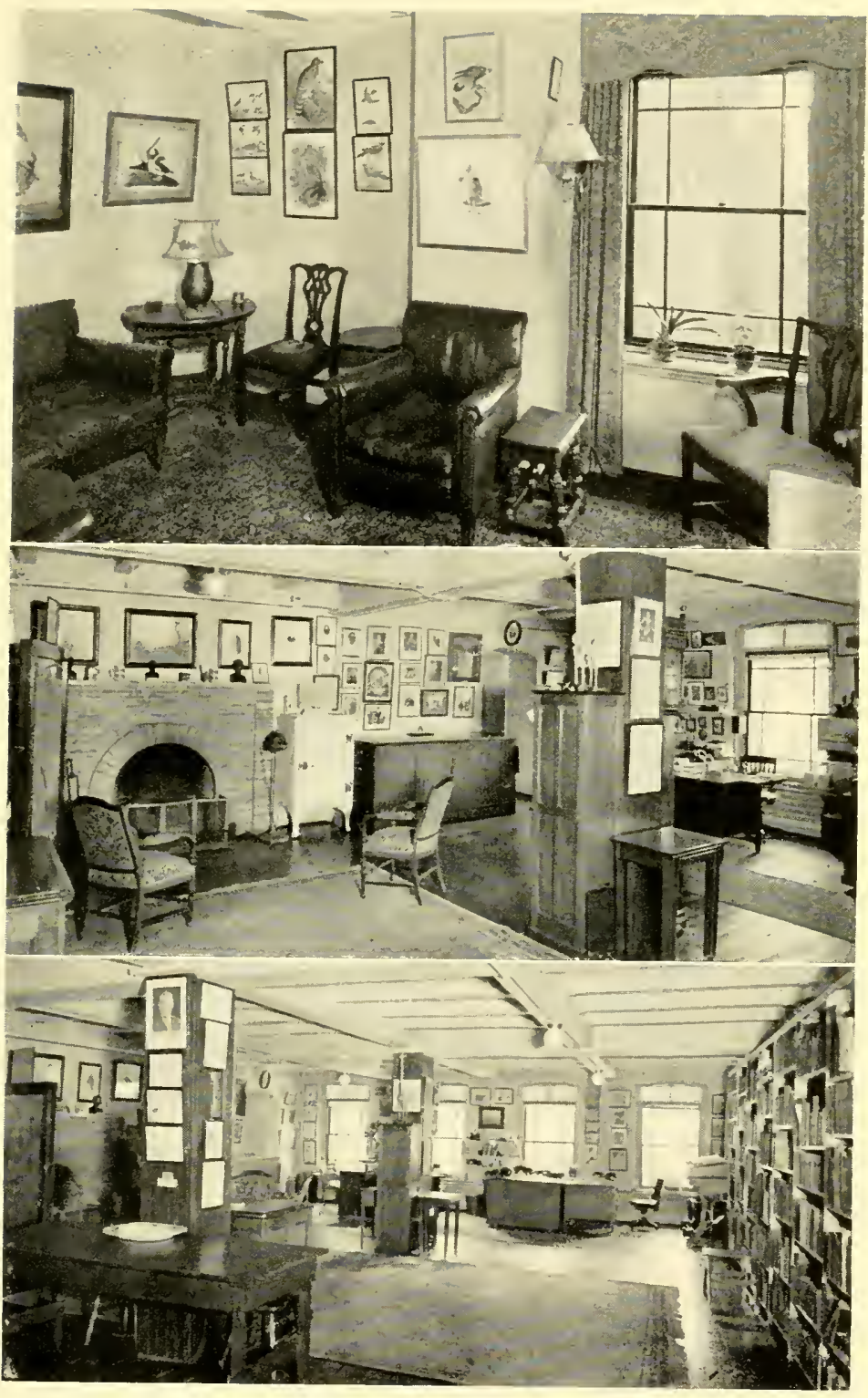

T. B.'s office in the Agassiz Museum

The author's library to the right; Agassiz fireplace to the left; the "Eateria" above 

Fanny Holmes, made each visit an intellectual adventure, and during the war years I came up from Havana to Washington on numberless occasions. They fixed me a room on the top story of the house, bound two single beds together with metal bands, and thus provided rest for my elongate figure. Once when the Tavern Club in Boston was going to give a dinner to Stephen Vincent Benét, which I greatly regret having missed, Owen Wister, then its president, wired the Justice for a message. I happened to be at hand when the telegram arrived and I seized it and the draft of the reply. These I now have framed together. Cousin Wendell wrote, "The first book I read about law was Benét on Court Practice. The last word I read about war was Benét's Jobn Brown's Body. The name has been a Benediction to me and I salute the bearer of it."

Mr. Lowell's appointment of me, Henry Bigelow, and several other colleagues to professorships in the Faculty of Arts and Sciences closed the breach which had previously existed between those servants of the University engaged in taxonomic research and those interested in other branches of biology. At times, largely because the biological laboratories were housed in the Museum building and all hands were frightfully overcrowded, the feeling had been bitter indeed.

Election as Trustee of the Carnegie Institution in Washington, the Woods Hole Oceanographic Institution, Boston Museum of Natural History, of which I have been president for years, the Peabody Museum of Salem, the Bishop Rhinelander Foundation, and above all to the Latin American Committee to choose Fellows under the John Simon Guggenheim Memorial Foundation - all these have brought 
me the opportunity for acquaintanceship with a number of distinguished men, many of whom have long been warm friends.

When I became Director of the Agassiz Museum, it was obvious that I should be unable to take care of my old pets, reptiles and amphibians. I was able to bring Mr. Arthur Loveridge from the Nairobi Museum, and I have always been glad I did so. His collections are better indexed and arranged than any other collection of reptiles in the world. As a matter of fact, there is only one more complete collection - the one in London. The collection of reptiles and amphibians now contains typical material of about 2300 species and there are something over 100,000 specimens representing the two groups.

The collection of birds has grown enormously. There are now about 300,000 specimens, and while this is not a large collection in comparison with the collections in London, New York, or Washington, it is singularly well-chosen and reflects a great deal of credit upon the curatorial capacity of its caretaker, James Lee Peters, who as a curator is a worthy successor to Outram Bangs.

I don't know why, but our collection of mammals has never grown the way the collection of birds has done. It amounts to about 60,000 skins. Nevertheless, it is a fine collection and a useful one as shown by the constant applications to borrow specimens for study elsewhere. It is now in the competent hands of Barbara Lawrence, whose husband, William Schevill, is our learned librarian.

Our enormous collection of fish is at last getting organized. It is hard to estimate how many specimens we really have, for it has been the custom in this department to 
catalogue lots and not individual specimens. There are something in the vicinity of 40,000 glass jars, 187 copper tanks for larger specimens, and five of what we call coffins, metal-lined receptacles about nine feet long, four feet wide, and three feet deep, which contain sharks and similar monsters. Many of the jars contain from 50 to 100 specimens, sometimes even more, so that your guess is as good as mine as to how many fish there actually are in the Museum.

During the last twenty years we have acquired by gift some enormous collections of insects - the collection of beetles made by my wife's uncle, Frederick Channing Bowditch, the Weeks collection of butterflies, the Wheeler collection of ants, the Harris collection, and many, many others. Considering the enormous accretions to a collection of insects which was already very large, the material is all in fine shape, largely owing to the unbelievable industry and wide learning of Professor Nathan Banks.

The collection of mollusks has grown to be one of the very largest in the world and William Clench keeps it in perfect order. It is a joy to behold. The objects themselves are inherently so beautiful that in the mass they are bewildering. A tremendous windfall came in the other day when Amherst College decided to entrust the care of the Adams collection to this Museum. Clench estimates that in the aggregate there are $140,07 \mathrm{I}$ lots of shells in the department, representing about 28 ,ooo species, and the total number may be 6,000,000 and the types 5000 to 6000 .

Frank Carpenter has built up the collection of fossil insects largely with his own hands, for he is as skilled in the field as in the laboratory. His collection is now the 
best in the world and he has 1376 types and something in the vicinity of 60,000 specimens.

Thanks to Mr. Agassiz, our collection of echinoderms is excellent. This is the department in which he himself was most interested. Years ago he invited Dr. Hubert Lyman Clark to come here to be his associate and study these groups and he still continues to have general charge. There are of sea urchins 554 species, represented by i 45 types. This is the largest proportion in relation to the total number of species in the world of any collection in the whole Museum. Brittle stars, represented by i I 4 species, 442 types; starfish, 759 species, I 50 types; and the sea cucumbers, represented by 484 species and 120 types, form a good proportion of the species described, but our collection of sea lilies, or crinoids, is not to be compared with the one which Austin Clark has built up in Washington. But of these groups there are in all 104,000 specimens and 7000 types, which is a good showing.

The Museum by tradition has always been interested in fossil fishes and we have a splendid collection of about 44,88 o specimens contained in no less than I 22 trays. I am not as familiar with this material as I should be, although I once worked for some time on the material from Mount Lebanon and found that we had a large proportion of the species which have been discovered there. Our recent accessions have been from Cuba and our oldest material is, of course, the European collections which were brought to this country by Louis Agassiz. This we are fortunate to possess for, generally speaking, American museums are weak in European material and for comparative purposes these collections are very important. Henry Stetson gave 
up a brilliant career studying the ancestral fishes to enter another field, in which he has also distinguished himself handsomely: the study of cores brought up by mechanically driven tubes which, forced into the sea bottom, provide a picture of the results of submarine sedimentation and hence of geologic history - details which a few years ago no one ever dreamt of.

In vertebrate paleontology we got off to a bad start, but now that Professor Alfred Romer has come from Chicago to take charge of these fossils, the collection has at last begun to grow. Professor Raymond has for many years had charge of the invertebrates, which is a gigantic collection, numbering close to a million specimens and contained in no less than 5549 trays. Our early primitive reptiles of North and South America are good and our mammal collection is growing fast.

The collection of Crustacea is growing well in Fenner Chace's hands. He estimates that he has I 500 type specimens and probably 200,000 specimens in all. I can only make a short statement concerning the other marine invertebrate groups - corals, jellyfishes, sponges, worms, and so on. There are probably about 800 types and 3380 lots of specimens in these categories which are not well represented in most museums. They frequently tend to accentuate the interest in conspicuous or spectacular material. We, on the other hand, have made a sincere attempt, at least, to build up a collection which is thoroughly well rounded.

This all sounds as if I were a hideous boaster, but I think for the sake of the historical record it is worth while taking note of the material which this Museum contains at the date on which I am writing. 

APPENDICES 



\section{For Zoographers Only}

Wallace stated, many years ago, that there are two different types of islands. Those which he calls oceanic islands have never by any likelihood been connected with other land. A good example is St. Helena. There are others where changes in the earth's crust have broken up large land masses into what are now islands. There has always been a lot of discussion among naturalists as to details, particularly in the East and West Indies.

It is clear that some separations can be explained by the fact that the oceans stand at a higher level now than they did when a large part of the water on the earth's surface was tied up in the form of ice during the several periods of maximum glaciation - when the polar icecap was enormously thick. I have argued principally concerning the West Indies, where many connections could be explained by this tie-up-of-ice theory, and I also believe that many of the deep passageways can be explained by what geologists call downthrust-faulting, where an area drops rapidly, geologically speaking of course, and makes a deep strait, sometimes counterbalanced by an upthrust somewhere else. I believe, for instance, that the mountain known as the Morro of Monte Criste on the northern coast of Hispaniola and the Yunque of Baracoa on the northeast coast of Cuba represent upthrust-fault blocks, while the separation between Jamaica and Haiti represents a comparatively recent downthrust area. The surface of the earth is in somewhat unstable equilibrium, what geologists call isostatic balance. 
At the risk of being dry and prosy I am giving here some arguments which I have used concerning the distribution of the animal life in the West Indies. This is matter of great theoretical interest with no practical application of any sort whatsoever.

A peculiarity of the fauna of Jamaica is the fact that while its proximity to Cuba is practically the same as its distance from Haiti, the evident relationship of the island's fauna with that of Haiti is well marked, while with Cuba it has only in common species which range widely through the West Indian region. Now a possible explanation of this offers itself when we examine a contour map of the Caribbean Sea. One of these was published as Figure 57 in $\mathrm{Mr}$. Alexander Agassiz's Three Cruises of the Blake (Bulletin of the Museum of Comparative Zoology, 1888, 14). Mr. Agassiz showed here that the Bartlett Deep, of over 3000 fathoms, extends between Cuba and Jamaica - doubtless a cleft of very ancient origin. But the depth of water between the great southern arm of Haiti and Jamaica is only from 500 to 800 fathoms. There is, it is true, a hole of a depth greater than this south of the Formigas Bank. This, however, is very limited in area, and does not fundamentally affect the condition of affairs. The water between Jamaica and the Mosquito Coast of Central America is, much of it, extremely shallow, mostly roo fathoms or less; though between the Pedro Bank and the Rosalind Bank there is a narrow stretch of water of about 500 fathoms depth.

Hydrographically, then, Jamaica is intimately related with both Central America and Haiti, and it seems probable 
that Lesser Antillean species and Central American species have come through a land connection which had nothing to do with Cuba. This would account, for instance, for the presence of the lizard Aristelliger in Haiti and Jamaica. The early separation of Jamaica from the mainland and from Haiti would account for the absence of types having such a distribution as Bufo, the common toads, and Amphisbaena, the blind lizards - which may easily have reached Haiti from the mainland of Central America by way of Cuba. Another connection must have existed between Cuba and the upper peninsula of Haiti after the separation of Jamaica from Haiti, and may we not suppose that the separation took place before the migration of Bufo or Amphisbaena had extended far enough to have reached Jamaica?

The question is undoubtedly far more complex than the suggestions contained in the previous paragraphs would indicate. Wallace in his Geograpbical Distribution of Animals (London, 1876, 2, p. 81) says: -

The West Indian Islands have been long isolated and have varied much in extent. Originally, they probably formed part of Central America, and may have been united with Yucatan and Honduras in one extensive tropical land. But their separation from the continent took place at a remote period, and they have since broken up into numerous islands, which have probably undergone much submergence in recent times. This has led to that poverty of the higher forms of life, combined with the remarkable speciality, 
which now characterizes them; while their fauna still preserves a sufficient resemblance to that of Central America to indicate its origin.

Masterly as is the above résumé of the status of conditions in the region under discussion, we suspect that Dr. Wallace would have written somewhat differently had he penned these lines fifty years later.

Another view resting solely on geological or physiographical evidence is that presented by Dr. R. T. Hill, who conducted investigations on the geographic relations of the West Indies under the auspices of Mr. Agassiz. In an article published in the National Geograpbic Magazine (May I896, 7, p. I8I) he concludes with these words: -

The Greater Antilles lie along the line of east-west corrugations and apparently represent nodes of greater elevation whereby the surfaces of these islands were projected above the waters as islands, which have persisted without continental connection or union with each other since their origin.

If we accept Mr. Hill's conclusion, which I for one certainly do not, it is impossible to account for a West Indian flora and fauna except by riding to death the old theory of "flotsam and jetsam." Ocean currents and prevailing winds could hardly have carried Central American types to any of the islands, as they work strongly in an opposing direction. This fact alone serves to prove the utter impossibility of Hill's conclusion. Even were winds and currents favoring, we know now that the number of types which will withstand a long submersion in sea water is 


\section{For Zoographers Only}

vastly smaller than was once supposed when it was thought that reptiles, amphibians, land mollusks, and in fact almost all orders of animals were carried hither and thither throughout the oceanic areas.

Mr. Agassiz has expressed an opinion on this series of relationships in his chapters in The Three Cruises of the Blake entitled "American and West Indian Fauna and Flora" and "Permanence of Continents and Oceanic Basins." The following (loc. cit., I4, p. II I) is pertinent: -

At the western end of tye Caribbean Sea the hundred-fathom line forms a gigantic bank off the Mosquito coast, extending over one third the distance from the mainland to the island of Jamaica. The Rosalind, Pedro, and a few other smaller banks, limited by the same line, denote the position of more or less important islands which may have once existed between the Mosquito coast and Jamaica. On examining the five-hundred-fathom line, we thus find that Jamaica is only the northern spit of a gigantic promontory, which perhaps once stretched toward Hayti from the mainland, reaching from Costa Rica to the northern part of the Mosquito coast. There is left but a comparatively narrow passage between this promontory and the five-hundred-fathom line which encircles Hayti, Porto Rico, and the Virgin Islands in one gigantic island.

The passage between Cuba and Jamaica has a depth of over three thousand fathoms, and that between Hayti and Cuba is not less than eight hundred and seventythree fathoms in depth. 
Referring to the same subject, Mr. Agassiz writes (pp. II2-1 I3): -

At the time of this connection, if it existed, the Caribbean Sea was connected with the Atlantic only by a narrow passage of a few miles in width between St. Lucia and Martinique, by one somewhat wider and slightly deeper between Martinique and Dominica, by another between Sombrero and the Virgin Islands, and by a comparatively narrow passage between Jamaica and Hayti. The hundred-fathom line connects the Bahamas with the northeastern end of Cuba; the five-hundred fathom line unites them not only with Cuba, but also with Florida. The Caribbean Sea, therefore, must have been a gulf of the Pacific, or have been connected with it by wide passages, of which we find the traces in the tertiary and cretaceous deposits of the Isthmus of Darien, of Panama, and of Nicaragua. Central America and northern South America at that time must have been a series of large islands, with passages leading between them from the Pacific into the Caribbean.

\section{And on page 113:-}

While undoubtedly soundings indicate clearly the nature of the submarine topography, it by no means follows that this ancient land connection did exist as has been sketched above. At the time when the larger West India Islands were formed and elevated above the level of the sea, they may have been raised as one gigantic submarine plateau of irregular shape, in which 
were included the Bahamas, Florida, Cuba, San Domingo, Porto Rico, and the Virgin Islands.

If we grant for the sake of argument that the Greater Antilles, like all Oceanic Islands, have received their fauna fortuitously, we must then explain the regularity and consistency with which the fauna has spread from two directions to populate such a great number of separate islands, with and against the prevailing wind and current. We find in the Lesser Antilles that the fauna is of almost purely northwest South American origin; as we pass thence to St. Thomas and to Porto Rico we note, as Stejneger has shown, the very evident twofold origin already mentioned. Then in Jamaica and Cuba the balance is in the opposite direction-types of Central American origin predominate.

The ancestry of Cricosaura, Amphisbaena, Bufo, and many other forms recently discovered prove that migration to these two islands took place along independent land bridges. The Jamaican coney belongs to a different section of the genus (Capromys), similar to the Haitian and different from the Cuban species, and Solenodon occurs in Cuba and Haiti and not now - nor, so far as we know, did it ever - in Jamaica; these facts prove or help to prove the independent connection with Haiti of both Cuba and Jamaica. Finally, in favor of the "bridge theory" Dr. Stejneger in a recent letter writes: "Whatever the mountain structure may show, certainly the geographical distribution of the animals shows that the Greater Antilles have been part of a continent at some time."

That Dr. Stejneger's opinion represents views which are 
gaining constantly in credence among present-day students of zoogeography there can be no doubt. Dr. R. F. Scharff in his History of the European Fauna (London, I 899) cites many experiments to show that land snails are more easily killed by immersion in salt water than many students in the past have supposed. Slugs in the act of crawling on twigs drop off immediately when subjected to a slight spray of sea water. Scharff (loc. cit., p. 17) continues: "If we supposed, therefore, that a slug had successfully reached the sea, transported on a tree-trunk, the moisture would tend to lure it forth from its hiding-place under the bark, whilst the mere spray would prove fatal to its existence." He adds that species of snails and slugs which lead an underground existence would be much less likely to get started on these sea voyages. The suggestion advanced by Darwin that young snails just hatched might adhere to the feet of birds roosting on the ground and then be transported seems improbable. Dr. Scharff in his European Animals: Their Geological History and Geographical Distribution (New York, 1907) states that Dr. Knud Andersen of Copenhagen has informed him in a letter that he has examined the legs and wings of many thousands of migratory birds, "that their legs were clean; and no seeds or other objects were found adhering to their feathers, beaks or feet. It has also been proved that birds migrate on empty stomachs."

There is also good authority for the statement that amphibians and earthworms very rarely or never occur on the two shores of a stretch of sea unless there is evidence showing the former existence of a land connection.

To quote again from Scharff (loc. cit., pp. I 8-20): - 
The formerly prevalent belief of the permanence of ocean basins has been shaken by the utterances of some of the greatest geologists of our day, while many positively assert that what is now deep sea of more than rooo fathoms was dry land within comparatively recent geological epochs.

He continues (p. 2 I) : -

Amphibians are affected in the same manner by sea-water as slugs are. The accidental transportal of an amphibian from the mainland to an island is therefore almost inconceivable. The presence of frogs, toads, and newts in the British Islands, in Corsica and Sardinia, indicates, if nothing else did, that all these islands were at no distant date united with the continent of Europe.

These quotations show that the belief held by the writer is not an unusual one, for certainly the fauna of the Greater Antilles is vastly richer in species than on the islands just mentioned.

For the person who may be interested to continue reading on this general subject I can recommend Dr. Schuchert's Historical Geology of the Antillean-Caribbean Region. This appeared in 1935 and not only is fascinating reading but contains a series of maps showing the distribution of the land areas in past geologic times which lend great support to the thesis which I have been defending for so many years.

Now a word further regarding isostasy. There is hardly a principle in geology concerning which there is greater 
uncertainty among geologists than the matter of isostatic balance. Only one thing is sure, isostasy must meet and conform to known or presumably known facts, and the fact that fundamental changes have taken place in the form of the earth's surface in recent geologic time is not to be denied. Such features as the Great Rift Valley of Africa and its continuation, the Red Sea and the Dead Sea, the Black Sea, the Basin of the Mediterranean, are held now by geologists to be the results of nothing but gigantic and fairly recent down-thrown fault-blocks. For other examples of changes of land and sea level with relation to each other, the Valley of the Po and the Central Valley of California are good evidence. The argument of isostatic balance may probably be held to control the conditions in the Pacific Basin as a whole, but isostasy cannot be used effectively as an argument in a relatively small area anywhere. Professor R. A. Daly tells me that there is clear evidence of the fragmentation of a great land mass, including the Fiji Islands and New Caledonia, but that there is no evidence known at present of such a condition outside of a line joining $Y$ ap, in the Caroline Islands, with the Fijis, Kermadecs, and New Zealand. In addition, radiolarian ooze, supposedly only to be derived from the deep sea, has long been known from Barbados, Trinidad, Aruba, Buen Ayre, and Curacaos, but the origin of this series of deposits has been somewhat in dispute. Two recent papers by Dr. G. A. F. Molengraff, however, describe deposits of which there can hardly be any question whatever; one is "On Oceanic Deep Sea Deposits in Central Borneo," ${ }^{1}$ while the other is

${ }^{1}$ Kon. Ak. Wet. Amsterdam, Reprint from proceedings of meeting June 26, 1909: 141-147. (Reprint: 1-7.) 
entitled "Over mangaan Knollen in mesozoischen diepzeeafzettingen van Borneo, Timor en Rotti, bun beteekenis en bun wijzer van Opstaan." 2 These papers show that on the islands of Borneo, Timor, and Rotti, at an elevation of about 4000 feet, very extensive deposits occur which a microscopical examination shows to be composed of radiolaria, together with the manganese nodules so characteristic of the deep sea. In other words, Molengraff has found an extensive area of deep sea floor raised to 4000 feet above the present sea level. On the southeast coast of Africa, W. M. Davis noticed the truncation by the present shore line of extensive concentric terraces, traceable far inland, which could only mean the down-faulting of a gigantic block of material to bring the shore line into its present state. It will be said at once that some of these changes of level have taken place in zones known to be incomplete in isostatic adjustment, but this is a matter of no moment whatsoever in comparison with the fact that change of level may be found to have occurred in the very areas where the islands under discussion are found. Celebes does not lie upon the continental shelf, and yet the island has an obviously continental fauna, and the late Mr. William D. Matthew, my principal and very friendly adversary in these arguments, has told me himself that Celebes has been a source of no small worry to him. Cuba has similarly a large fauna derived from the American continent, although it does not lie upon the continental shelf. Vaughan, a thoroughly conservative observer, believes (in litteris) that Cuba was quite possibly separated, by the down-faulting

${ }^{2}$ Kon. Ak. Wet. Amsterdam 23: 1058-1073. (Reprint: 1-16.) 
of blocks of material, from both Haiti and the mainland.

Dr. Matthew was the most scholarly student of fossil mammals which America has produced. He was for many years at the American Museum of Natural History in New York and then, preferring a more tranquil life, went to the University of California, where he died some years ago. We carried on a sort of symposium in print on this matter of distribution for some years. It was a pleasure to differ from Matthew because he was so perfectly courteous and invariably impersonal. In 1939 the New York Academy of Sciences brought out a special publication, with an excellent portrait of my old friend, a reprinting of his Climate and Evolution and my remarks (Special Publications of the New York Academy of Sciences, Vol. I, pp. i-xii, I-223). The upshot of all this is that we shall probably know a great deal more about this subject in the years to come, as the paleontological evidence is piling up. Even now we know more about the fossil animals of Cuba, Jamaica, and Puerto Rico than we did a generation ago very much more - and not improbably more evidence will be forthcoming in the future. Once I thought this was a "pay your money and take your choice" problem, because there is good argumentation both ways, but I feel now that Matthew would have felt quite differently had he lived to read Schuchert's book, published in $\mathbf{1 9 3 5 .}$ 


\section{Render unto Caesar}

Over the course of years the director of a museum has the opportunity of working with many associates and young assistants, and it is to these oncoming naturalists and curators that I wish to devote my last few pages. This record would not be complete without a word of recognition of the constant and faithful assistance which I have received from four secretaries - Beatrice Johnson, Frances M. Wilder, Elizabeth Grundy, and, above all, Helene M. Robinson.

Added to this is the fact that some of my graduate students have, to my great satisfaction, turned out to be distinguished scholars and remain warm friends to this day. I think at once of Emmett Reid Dunn, William M. Mann, John Wendell Bailey, Afranio do Amaral, and Alexander Graham Bell Fairchild and Marston Bates, son and son-inlaw of my old friend David Fairchild. Others who have contributed greatly to my happiness on numberless occasions have been Margaret Porter Bigelow, to whom, with Archie and Margie Carr of the University of Florida, I presume to feel in loco parentis; the Harold Loomises of Coconut Grove and their children Margie and Jim; Dick and Helen Gaige at Ann Arbor; Elisabeth Deichmann and her sweet mother. I hold in the warmest affection Dr. Theodore White, my companion in digging at the Thomas Farm in Florida, and Henry Seton, who has gathered some wonderful material for us in the fossil fields of the West. I miss Jim Greenway, now in the Navy, every time I pass 
the Bird Room door. The Entomological Department has lost Philip Darlington to the Army, but it has gained Vladimir Nabokov, a poet as well as a scientist. We need Philip back badly, another reason for wishing that the war may end soon.

I must pay tribute without stint to the wide learning of two colleagues who are as good botanists as they are zoologists - Ludlow Griscom and Joseph Bequaert - ornaments to any faculty. The Mollusk Department misses John Higginson Huntington, my nephew, who is driving an ambulance in North Africa, and Tucker Abbott, who came in only yesterday for a last farewell, his newly won wings proudly displayed. Richard Winslow Foster, a real anchor to windward, a good scientist and a generous benefactor of the Museum as well, is still with us, his asthma having kept him out of the Army. It is a horrid thing to say, but I am glad, because after all we have got to take care of the material which has been entrusted to our charge and assume that this war is not going to last forever. Henry Drummond Russell, formerly associated with the mollusks here, now helps me with the New England Museum of Natural History in Boston.

The Department sadly misses Harold J. Coolidge, who long ago joined the Office of Strategic Services.

Russell Olsen has acquired great technical skill not only in taking fossils from the matrix, but in restoring them as well. He serves the Museum with unselfish devotion and has a good eye for the way exhibits ought to look.

Ever since my junior year in college Mr. Eugene N. Fischer has been making lovely drawings to illustrate the Museum publications and he is doing the very same thing 
today. Latterly Mrs. Myvanwy Dick, another artist of rare skill, has volunteered to help with illustrations when we were hard pressed.

If anything ever happens to Maxwell French I think I'd resign the next day. He does more different odd jobs with less waste of time than anyone I know. He can tell you the cost of an airmail letter to South Africa, how many inches long a parcel can be and still go by post, and he can pack the most delicate specimens so that they will reach their destination safely.

Unfortunately we cannot afford a full-time Curator of Fishes at the present writing, but William Schroeder of the Woods Hole Oceanographic Institution helps us mightily.

The Reptile Department doesn't seem itself without Benny Shreve's cheerful countenance. He has helped us for years, meticulously accurate, in determining Neotropical reptiles and amphibians, which are his special pets.

Elizabeth Bangs Bryant has for years cared for our enormous collection of spiders and has written many papers describing new species of this usually somewhat neglected group.

We miss Llewellyn Price, an artist with a keen nose for a fossil, and a delightful companion. At present he is on loan to the Geological Survey of Brazil.

I am perfectly sure that I have left out some of those whom I particularly wanted to salute, but if I have done so it has been unintentional. To me, the Museum is more like a person than a thing, an object of affection that comes directly next to my nearest and dearest. Here we all call one another by our first names. There is no Professor This or Curator That or Director So-and-so. We are Bill 
and Henry, Liska, Dick and Philip, and I hope that this tradition may continue forever. It was not always so, since my predecessor was not built this way. He felt that his resignation would inevitably reveal his incompetence (this, however, is not worth elaborating), and his studied unkindness to me during the last years of his life was a bitter eye-opener which I hardly deserved. I hope when the time comes to make way for my successor that I may step out gracefully and help him take over one of the greatest and most thrilling tasks which a man can assume. 







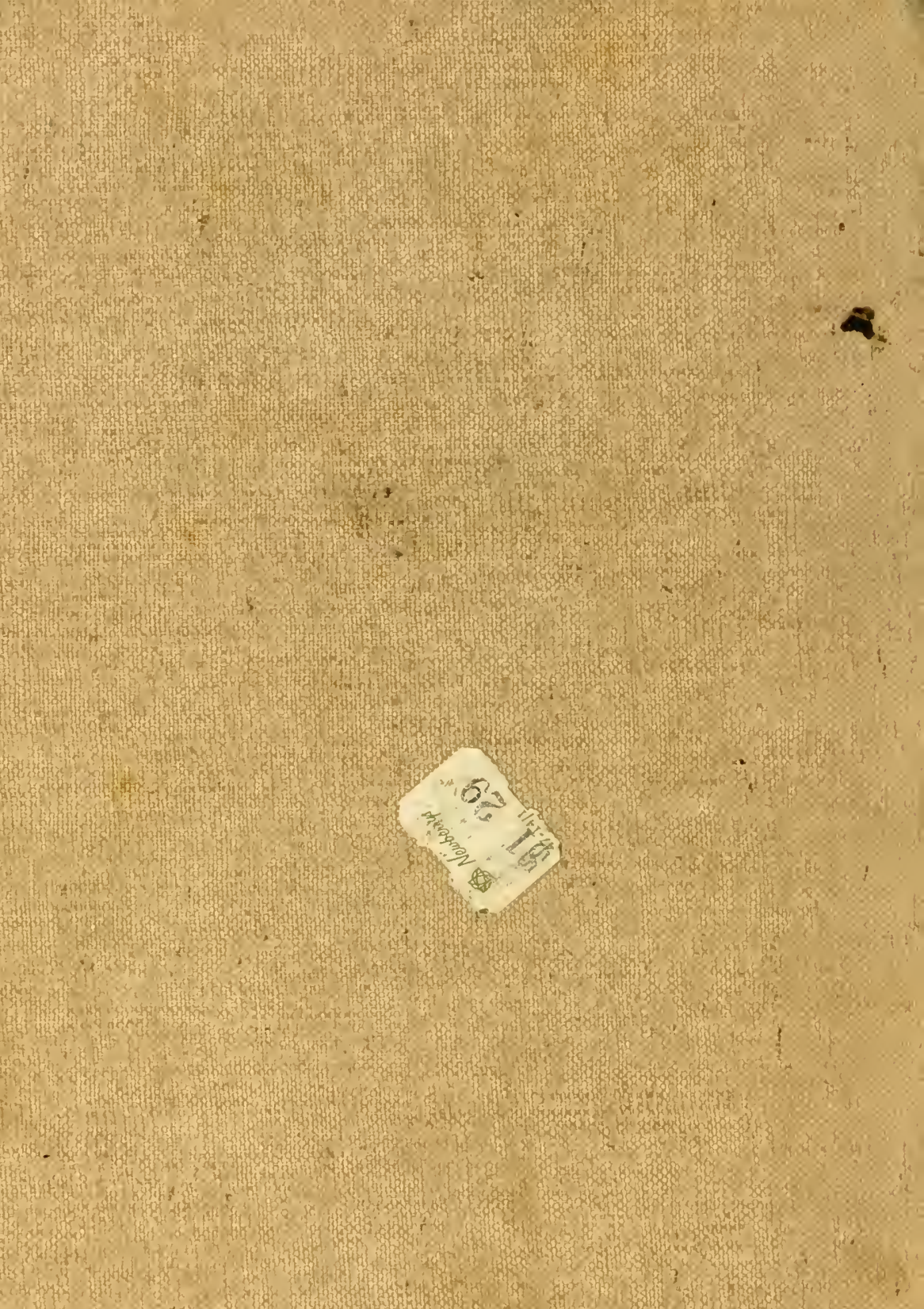

